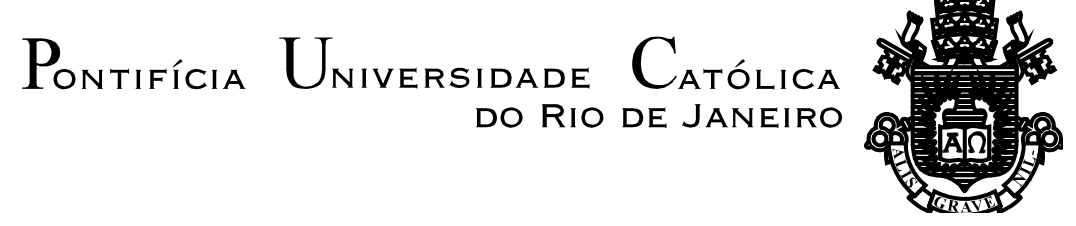

Tiago Leite Costa

\title{
O PERFEITO COZINHEIRO DAS TEORIAS DESTE MUNDO: ENSAIOS DE OSWALD DE ANDRADE (1945-54)
}

\section{Tese de Doutorado}

Tese apresentada ao Programa de Pós-Graduação em Literatura, Cultura e Contemporaneidade da PUC-Rio como requisito parcial para obtenção do título de Doutor em Letras/Literatura, Cultura e Contemporaneidade.

Orientador: Prof. Júlio Cesar Valladão Diniz 

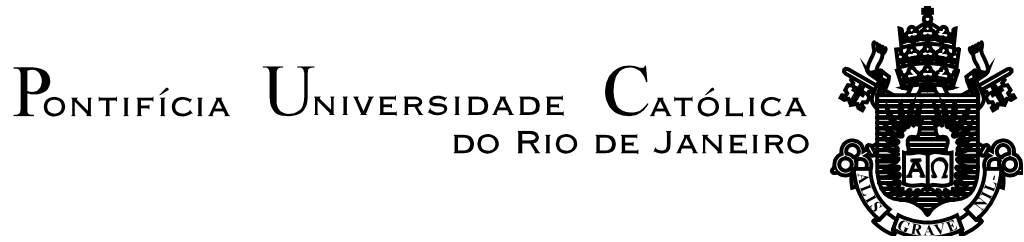

Tiago Leite Costa

\section{O PERFEITO COZINHEIRO DAS TEORIAS DESTE MUNDO: ENSAIOS DE OSWALD DE ANDRADE (1945-54)}

Defesa de Tese apresentada como requisito parcial para obtenção do grau de Doutor pelo Programa de PósGraduação em Literatura, Cultura e Contemporaneidade do Departamento de Letras do Centro de Teologia e Ciências Humanas da PUC-Rio. Aprovada pela Comissão Examinadora abaixo assinada.

Prof. Júlio Cesar Valladão Diniz

Orientador

Departamento de Letras - PUC-Rio

Profa. Vera Lucia Follain de Figueiredo Departamento de Letras - PUC-Rio

Profa. Marilia Rothier Cardoso Departamento de Letras - PUC-Rio

Prof. André Monteiro Guimarães Dias Pires

UFJF

Profa. Mónica Bernabé Universidade Nacional de Rosário

Profa. Denise Berruezo Portinari Coordenadora Setorial do Centro de Teologia e Ciências Humanas - PUC-Rio

Rio de Janeiro, 26 de abril de 2013 
Todos os direitos reservados. É proibida a reprodução total ou parcial do trabalho sem a autorização do autor, do orientador e da universidade.

Tiago Leite Costa

Graduou-se em Comunicação Social pela Universidade Federal do Rio de Janeiro em 2003. Obteve o título de mestre em Comunicação Social pela Pontifícia Universidade Católica do Rio de Janeiro em 2008. Tem experiência nas áreas de Comunicação e Letras, atuando principalmente nos seguintes temas: modernidade, contemporaneidade, modernismo, vanguardas literárias, crítica literária e cultural, ensaio, crônica, Nelson Rodrigues e Oswald de Andrade.

Ficha Catalográfica

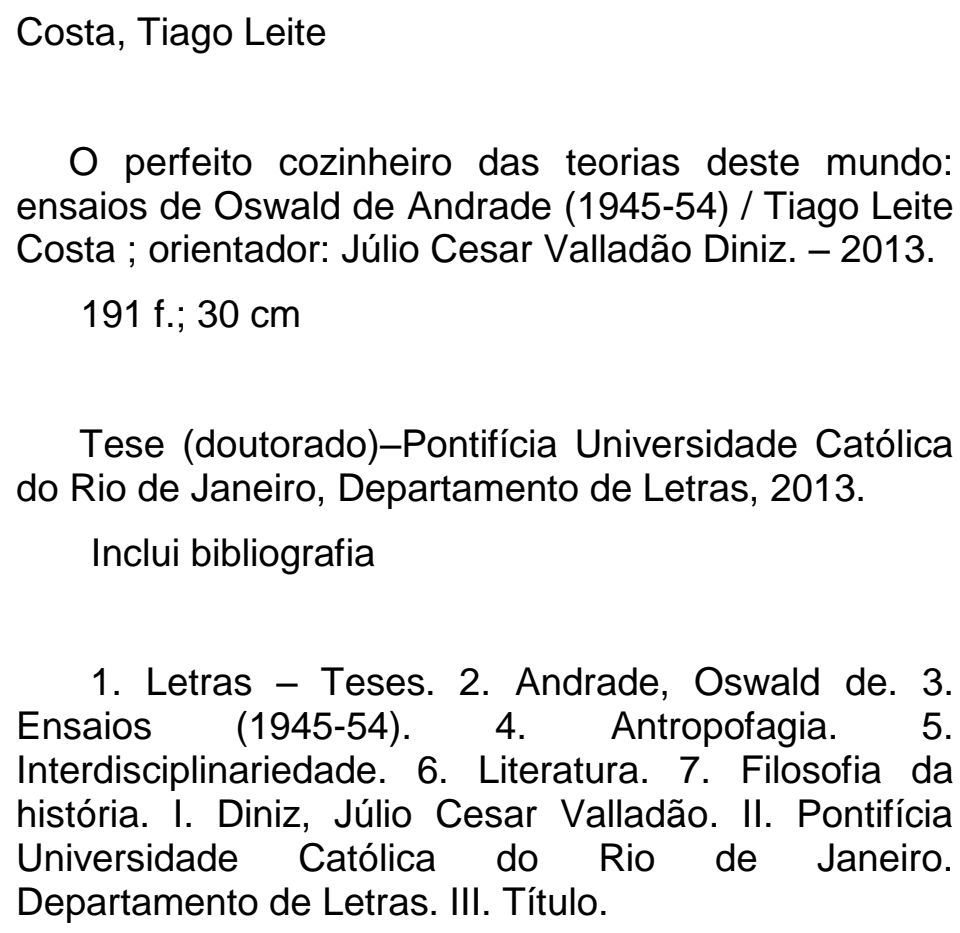
ensaios de Oswald de Andrade (1945-54) / Tiago Leite Costa ; orientador: Júlio Cesar Valladão Diniz. - 2013.

$191 \mathrm{f.} ; 30 \mathrm{~cm}$

Tese (doutorado)-Pontifícia Universidade Católica do Rio de Janeiro, Departamento de Letras, 2013.

Inclui bibliografia

1. Letras - Teses. 2. Andrade, Oswald de. 3. Ensaios (1945-54). 4. Antropofagia. 5. Interdisciplinariedade. 6. Literatura. 7. Filosofia da história. I. Diniz, Júlio Cesar Valladão. II. Pontifícia Universidade Católica do Rio de Janeiro. Departamento de Letras. III. Título. 


\section{Agradecimentos}

Ao Júlio, pelo afeto e pela inteligência que me ofereceu nos últimos quatro anos.

Sobretudo, pela orientação precisa e pelo estímulo à ousadia.

Ao meu pai, genial e generoso.

À minha mãe, pelo amor e pela confiança.

À Vera, pela formação e pela amizade, sem as quais eu não teria ingressado no doutorado.

À Marília Rothier Cardoso, que além de ter contribuído muito para a tese com sua leitura e com suas aulas, foi extremamente atenciosa como coordenadora do intercâmbio entre a UNR e a PUC.

À Mónica Bernabé, pela disponibilidade afetiva e intelectual com que me recebeu em Rosário. Agradeço, igualmente, pelas muitas ideias e autores que me apresentou, e que enriqueceram esse trabalho.

Ao André Monteiro, pelos importantes debates na elaboração do projeto de tese e pela gentileza de aceitar o convite para a banca.

Ao professor Gonzalo Aguillar, que me disponibilizou os arquivos de seus excelentes ensaios sobre Oswald de Andrade com alegre despojamento e generosidade.

A CAPES pelo financiamento da temporada de estudos em Rosário no segundo semestre de 2012. 


\section{Resumo}

Costa, Tiago Leite ; Diniz, Júlio Cesar Valladão. O perfeito cozinheiro das Teorias deste mundo: ensaios de Oswald de Andrade (1945-54). Rio de Janeiro, 2013. 191p. Tese de Doutorado - Departamento de Letras, Pontifícia Universidade Católica do Rio de Janeiro.

A tese tem como objetivo apresentar a antropofagia filosófica de Oswald de Andrade, com base em seus ensaios, artigos e teses escritas entre os anos de 1945 e 1954. Durante esta década, o autor desenvolveu um conjunto de reflexões no qual confronta os diversos aspectos de duas inclinações psicoculturais da espécie: o matriarcado e o patriarcado. Esta pesquisa pretende introduzir o leitor nos conceitos principais desta teoria. A tese também examina o estilo singular dos ensaios, debatendo como o autor lida com a oposição entre os campos discursivos da interpretação e da criação (teorias do conhecimento e ficção), e produz uma revisão heterodoxa de eventos e idéias tradicionais da história ocidental.

\section{Palavras-chave}

Oswald de Andrade; ensaios (1945-54); antropofagia; interdisciplinariedade; literatura; filosofia da história. 


\section{Abstract}

Costa, Tiago Leite; Diniz, Júlio Cesar Valladão (Advisor). The perfect cook of the theories of this world: Oswald de Andrade's essays (194554). Rio de Janeiro, 2013. 191p. Doctoral Thesis - Departamento de Letras, Pontifícia Universidade Católica do Rio de Janeiro.

The thesis aims to present Oswald de Andrade's philosophical anthropophagy, based on his essays, articles and thesis written between the years of 1945 and 1954. During this decade, the author developed a series of reflections in which confronts the various aspects of two psychocultural inclinations of the species: the matriarchy and the patriarchy. This research intends to introduce the reader into the main concepts of this theory. The thesis also examines the singular style of the essays, discussing how the author copes with the opposition between the discursive fields of interpretation and creation (theories of knowledge and fiction), and produces a heterodox review of traditional events and ideas of Western History.

\section{Keywords}

Oswald de Andrade; essays (1945-54); anthropophagy; interdisciplinarity; literature; philosophy of history. 


\section{Sumário}

Introdução

1. Antes, durante e em torno da antropofagia: origem

e originalidade na América Latina

2. O primitivismo segundo a genealogia e a dialética antropofágicas

2.1. O ensaísmo antropofágico

2.2. O índio abstrato

2.3. Genealogia antropofágica

2.4. Dialética antropofágica

3. O matriarcado, o patriarcado e o homem natural tecnizado

3.1. O sentimento órfico

3.2. O matriarcado

3.3. O patriarcado

3.4. O homem natural tecnizado

4. O ciclo das utopias

6. Conclusão 


\section{Lista de abreviações dos ensaios}

Do Pau-Brasil à antropofagia e às utopias: manifestos, teses de concursos e ensaios (1972)

MT - Meu testamento (1944)

Al - Arcádia e inconfidência (1945)

CFM - A crise da filosofia messiânica (1950)

AHC - Um aspecto antropofágico da cultura brasileira: o homem cordial (1950)

MU - A marcha das utopias (1953)

VM - Variações sobre o matriarcado (sem data)

AM - Ainda o matriarcado (sem data)

AV - Achado de Vespúcio (sem data)

OS - Posição de Sartre (sem data)

DA - Descoberta da África (sem data)

\section{Estética e Política (1991)}

SLB - A sátira na literatura brasileira (1945)

IM - Informe sobre o modernismo (1945)

MAD - Mensagem ao antropófago desconhecido (1946)

SI - O sentido do interior (1948)

CD - Civilização e dinheiro (1949)

VNL - Velhos e novos livros (1950)

RP - Reabilitação do primitivo (1954)

OA - O antropófago (1954) 
OC - Do órfico e mais cogitações (1954)

Ponta de Lança (1991b)

SR - Sobre o Romance (1943 em jornal 1945 em livro)

ASV - Aqui foi o sul que venceu (1943 em jornal e 1945 em livro)

SM - Sol da meia-noite (1943 em jornal e 1945 em livro)

CP - O caminho percorrido (1944 conferência e 1945 em livro)

Jornal

TEL (1996) - Telefonema (crônicas de 1945-54)

FSF (2010) - Feira das sextas (crônicas de 1943-1945)

DD (1990) - Dentes do Dragão (entrevistas de 1924-1954) 
Sei de uma criatura antiga e formidável Que a si mesma devora os membros e as entranhas

Com a sofreguidão da fome insaciável (...)

Ama de igual amor o poluto e o impoluto Começa e recomeça uma perpétua lida, E sorrindo obedece ao divino estatuto Tu dirás que é a Morte: eu direi que é a vida

Machado de Assis, Uma Criatura

Supersticioso e religioso de formação, nunca perdi essas taras, mesmo adotando um credo materialista.

Gosto de propor os meus pontos de vista, ensinar o que sei, ainda que errado, e intervir mesmo no que não sei.

Meu temperamento traz duas constantes que dialeticamente se revezam. Sofro como Dostoiévski e arrisco como Nietzsche.

Só o escritor interessado pode interessar.

Oswald de Andrade, Dentes do Dragão 


\section{Introdução}

Quando terminei minha dissertação de mestrado sobre as crônicas políticas do "reacionário" Nelson Rodrigues, Vera Figueiredo, que havia orientado o trabalho, me disse algo mais ou menos assim: "Bem, agora você podia ler as crônicas do Oswald de Andrade, pra dar um refresco".

De Oswald, tinha apenas uma vaga noção de que se tratava de um dos representantes da ala não conservadora do modernismo. Até conhecia e gostava dos Manifestos Pau-brasil e Antropófago, mas por motivos relativamente alheios aos seus significados históricos. Para mim, a antropofagia era um conjunto de estereótipos: índio, canibal, sincretismo, Abaporu. Em suma, "macumba para turista".

Fui pesquisar o autor e a fortuna crítica de sua obra. Aos poucos, descobri seus textos e o folclore em torno de sua personalidade polêmica. Entendi melhor seu papel no modernismo e as distintas reaparições da antropofagia na cultura brasileira da década de 1950 em diante. Um dia, entre as prateleiras de uma biblioteca, me deparei com o original da tese A crise da filosofia messiânica.

Foram algumas semanas de luta com aquele texto desconcertante. Ele parecia trazer uma mensagem cifrada. Era trivial e inacessível, agudo e atarantado, cético e utópico. Meio nietzscheano, meio marxista, meio brasileiro. Evidentemente, eu ainda não entendia direito que, na realidade, o texto era profundamente antropofágico.

Passou-se algum tempo e Vera me apresentou ao Júlio Diniz, que viria a ser o orientador desta tese. Na época, ele estava começando um seminário em parceria com o André Monteiro sobre Oswald e Mário de Andrade. Fui assistir como ouvinte e tive a oportunidade de aprofundar, em todos os sentidos, meus parcos conhecimentos sobre a antropofagia. Lembro que as aulas eram intensas, com discussões acirradas, que não se furtavam a debater os temas mais ecléticos: literatura, história do Brasil, capitalismo, metafísica, sexualidade e daí por diante. 
Por fim, levei comigo a pergunta: o que o pensamento de Oswald de Andrade ainda pode oferecer à crítica da cultura contemporânea?

Nos anos que se seguiram, reparei que muita gente não suporta mais falar sobre antropofagia. Acham o tema ultrapassado e elementar. Ao ouvirem a defesa do valor do hibridismo, seguida de um convite ao nacionalismo eclético, suspiram entediados - e com razão. Concordo que a abordagem convencional da antropofagia já deu o que tinha que dar.

Por outro lado, percebi que outras pessoas ainda enxergam no conceito a matéria prima para um pensamento inventivo, capaz de aliar rigor e ousadia. Da forma como vejo estes simpatizantes (leitores ou autores), eles parecem se dividir em dois grupos. Uns ressaltam o que havia de antecipatório na antropofagia, cotejando-a com as teorias da cultura atuais. Outros, ao contrário, observam como as controvérsias de Oswald revelam a permanência de dilemas modernos na contemporaneidade. Tendo a pensar como estes últimos, embora reconheça engenhosidade e originalidade nos primeiros.

Seja como for, o problema da atualidade da antropofagia é proporcional ao tamanho da sua repercussão. Da divulgação do Manifesto antropófago até hoje, ela tem sido exaustivamente usada como metáfora da nossa cultura e da criação de nossos artistas. O resultado é que se tornou um paradigma heterodoxo, que se ajusta aos mais variados e minuciosos experimentos criativos, mas que também serve de subterfúgio para evitar impasses políticos e estéticos brasileiros.

Além de ser uma das principais linhas de força da produção artística nacional, a antropofagia é igualmente uma das nossas mais bem sucedidas inciativas no campo teórico. A prova disso está na frequência com a qual é requisitada pelas mais diferentes disciplinas. Das mais anárquicas às mais obedientes reflexões sobre a cultura, a antropofagia tem sido uma ferramenta conceitual recorrente, dentro e fora do âmbito dos estudos literários.

Ao resolver investigar o tema, portanto, me vi tendo que responder a óbvia pergunta: qual a relevância de rediscutir um assunto tão digerido por tantos trabalhos ao longo das últimas décadas?

Acontece que, apesar da longevidade e importância da antropofagia, a verdade é que o trabalho ensaístico de Oswald de Andrade, no qual esclarece suas 
principais concepções teóricas, foi pouco estudado. Embora existam algumas análises penetrantes, tanto de intelectuais tarimbados quanto de alguns estudiosos mais jovens, ainda há muito a revirar no material correspondente aos últimos dez anos da produção intelectual do antropófago.

Essa tese tem como objetivo apresentar e comentar os principais conceitos desenvolvidos por Oswald de Andrade nos ensaios, artigos, teses, conferências e entrevistas que realizou durante o período de 1944 a 1954. Nessa época, o autor elaborou a "visão de mundo antropofágica", por meio de uma filosofia da história de cunho ensaístico. Pretendo analisá-la, buscando, sempre que for pertinente, discuti-la à luz dos dilemas culturais contemporâneos.

No intuito de aprofundar a especificidade das hipóteses contidas nos ensaios, exclui os manifestos modernistas, a Revista de Antropofagia e os trabalhos ficcionais (prosa, poesia, dramaturgia) do meu objeto de estudo. Busquei trabalhar com conteúdos menos conhecidos do pensamento de Oswald, elaborados no citado espaço de tempo.

Em função disso, dei preferência aos termos "antropofagia ensaística" e "ensaios antropofágicos" para denominar o corpus textual que irei trabalhar. Entretanto, também me refiro ao conjunto dessas reflexões como "Filosofia antropofágica" e "Antropofagia filosófica", seguindo a designação dada pelo próprio Oswald em algumas ocasiões. Todos esses termos serão usados como sinônimos e assinalam a articulação dos conceitos que compõem a teoria forjada pelo autor nos textos previamente discriminados no índice de abreviaturas, incluído no início da tese.

Minha curiosidade pelos ensaios veio do fato de que, mesmo que alguns deles sejam razoavelmente conhecidos no meio acadêmico, poucos pesquisadores consideram o material digno de um debate mais aprofundado. Apesar disso, a antropofagia permanece continuamente solicitada como operador conceitual e estético nos mais diversos campos de estudo. Resolvi, então, pesquisar mais atentamente esta teoria tão popular quanto desconhecida.

Uma possível explicação histórica para essa contradição é que, desde que se engajou na militância política, no início da década de 1930, até a sua morte, Oswald foi gradualmente alijado do meio artístico-intelectual por seus 
contemporâneos. Quando não era censurado pelo DIP, era boicotado por algum dos inúmeros inimigos que fez ao longo da carreira. Com o tempo, sua importância entre os artífices do movimento de 1922 começou a ser questionada. Ele foi ganhando a pecha de mero agitador e de coadjuvante. Em consequência, prevaleceu o mito e a personalidade polêmica sobre os escritos. Estes mal eram lidos e, quando o foram, não eram levados a sério ${ }^{1}$.

Uma mostra disso é dada pela blague de Nelson Rodrigues (desafeto tardio de Oswald), que numa de suas típicas provocações comentou: "São Paulo dá tudo, menos romance. O leitor poderá lembrar de Oswald de Andrade. Mas a obra romanesca de Oswald de Andrade tem, exatamente, três leitores:- os irmãos Campos e José Lino Grünewald” (Rodrigues, 2002, p.99).

O comentário não era gratuito. De fato, ninguém lia Oswald de Andrade. A maioria dos seus livros eram raridades esgotadas. Foi muito por conta do garimpo de Haroldo e Augusto de Campos, na década de 1950, que começou o renascimento do autor e da antropofagia. Alguns anos depois, em 1965, com a montagem da sua inédita peça $O$ Rei da Vela, por Zé Celso Martinez Correa, Oswald ameaçaria do túmulo o confortável posto de Nelson Rodrigues como inventor da dramaturgia moderna brasileira. Mas isso é outra história.

O que importa é que, desde então, o Concretismo dos irmãos Campos e Décio Pignatari, O Rei da Vela do Teatro oficina, o Cinema Novo, o Tropicalismo e a Poesia Marginal, para citar alguns exemplos célebres, tornaram-se ícones da potência de reinvenção da antropofagia e do pensamento de Oswald de Andrade.

Não podemos esquecer que todos esses movimentos ocorreram em contextos marcados por intenso embate político e ideológico. Querendo ou não, seus representantes estavam naturalmente envolvidos nas batalhas entre esquerda/direita, nacionalismo/cosmopolitismo, alta cultura/cultura de massa, etc..

Talvez esse seja o motivo para que tanto artistas quanto críticos das décadas de 1950-60-70 tenham encontrado afinidade com a antropofagia modernista e com sua revolucionária interpretação do Brasil. Em contrapartida, os

\footnotetext{
${ }^{1}$ Em 1953, um ano antes de morrer, Oswald lamentava impotente: "Me considero um homem sem profissão definida (...). Sim, porque a verdade é esta: os escritores não me levam a sério, nem sequer me consideram também escritor." (ANDRADE In: RUFFATO, 2011, p.34). Sobre a relação entre a personalidade polêmica de Oswald e a recepção de sua obra, ver o indispensável ensaio de Antonio Candido, Digressão sentimental sobre Oswald de Andrade (CANDIDO, 2004).
} 
ensaios de 1944-54 foram ignorados ou tidos como simples continuidade do Manifesto. O que não se alinhava ao debate da cultura nacional da época, na maior parte das vezes foi negligenciado.

Certamente, os ensaios dão alguma continuidade à antropofagia modernista. Do contrário, faria pouco sentido qualificá-los de antropofágicos. Com efeito, discussões significativas sobre a identidade nacional e sobre o papel do intelectual e do artista periféricos estão presentes nesse segundo momento. Entretanto, de modo geral, esses textos fogem ao domínio do local, realizando amplas considerações sobre vários temas relacionados à história da civilização ocidental.

É verdade, também, que as diretrizes básicas do Manifesto são o ponto de partida dos ensaios. Estão lá as noções de pluralidade e simultaneidade temporal; de síntese entre razão e mito; de matriarcado/patriarcado, de transformação do tabu em totem, de bárbaro tecnizado e de idade de ouro. Contudo, todas essas ideias recebem formulações mais consistentes, agregando novos sentidos, relacionados a assuntos distantes das preocupações modernistas. Afora isso, os conceitos de primitivo e utopia adquirem tessituras ainda mais polissêmicas, sem contar que a colonização portuguesa muda de sinal e passa a ser vista positivamente, no âmbito da oposição entre Contra-reforma e Reforma.

Resumindo, pode-se dizer que as preocupações com moderno/arcaico, nacional/estrangeiro, alta cultura/cultura popular, prementes no Manifesto, embora não desapareçam, cedem espaço para o exame dos binômios natureza/cultura, indivíduo/coletivo, metafísica/imanência, religião/razão e senhor/escravo, revisitados na tradição ocidental.

Oswald analisa episódios da história dos costumes, das religiões e dos sistemas de pensamento ocidentais, da perspectiva da "filosofia antropofágica". Isso significa que ele interpreta a história da civilização como a guerra material e simbólica entre duas tendências psicossocias da espécie humana: o matriarcado e o patriarcado. Partindo desse raciocínio, comenta a ascensão do patriarcado no mundo pré-helênico e na Grécia antiga, passa ao cristianismo e ao Império romano, investiga a realidade feudal e as inúmeras variantes da sua decadência, tais como o surgimento da burguesia renascentista, a Reforma luterana, e, é claro, 
o aparecimento do Novo mundo. Este último será o prenúncio de um novo matriarcado, e o ponto de referência das suas considerações sobre acontecimentos e ideias marcantes da modernidade.

Nesse pequeno sumário, pode-se calcular o grau de quixotismo, improviso e especulação da empreitada oswaldiana. Realmente, não são poucos os assuntos em que ele opina. No universo de tópicos, autores e teorias que participam desse projeto epopeico, cheguei à conclusão de que, se nada garantia a contemporaneidade da antropofagia, ao menos deveria haver algo de novo a ser dito sobre ela. Foi a partir dessa hipótese que procurei escrever a tese.

Em princípio, diante do excesso de referências salpicadas nos ensaios, sem maiores elaborações, relutei em assumir plenamente o conjunto das cogitações oswaldianas. Parecia-me que o caminho mais viável era me limitar ao exame da sua escrita da história. Com o tempo, no entanto, suas ideias foram se tornando mais claras para mim. A miscelânea inicial foi ganhando formatos e sentidos estáveis, em função da coerência interna entre as noções principais. Pude perceber com mais nitidez a correlação entre os ensaios que, de início, apenas intuía.

Resolvi esquematizar as especulações de Oswald, articulando os textos dispersos em grupos temáticos principais. Claro que, ao me dispor a um trabalho a princípio tão anti-antropofágico, tive que lidar com a iminência do que o autor considerava "a confusão que se faz entre seriedade do espírito e, por exemplo, a sisudez de uma sessão acadêmica, com suas ratazanas fardadas e a coleção de carecas de louça" (MT, 1972, p.23). Todavia, terminei optando por essa saída supostamente mais convencional por dois motivos.

$\mathrm{O}$ primeiro está relacionado à radicalidade que o termo interdisciplinar alcança com Oswald. Diante de uma obra que transita livremente por referências literárias, filosóficas, históricas, mitológicas, antropológicas, sociológicas e psicológicas, entendi que era preciso criar algum recorte para não mergulhar na aleatoriedade. Em seguida, conclui que a direção mais aconselhável a percorrer deveria ser dada pelo próprio autor. Assim, dividi os capítulos e sub-capítulos de acordo com a importância e a frequência dos conceitos nos ensaios antropofágicos. 
Nesse sentido, toda bibliografia utilizada na tese serviu fundamentalmente para esclarecer a teoria de Oswald. Não pretendi elaborar qualquer discussão mais aprofundada sobre os autores de apoio. Suas ideias serão apresentadas unicamente em função do diálogo com a "filosofia antropofágica" e com os eventuais debates sobre a cultura contemporânea que os ensaios venham a suscitar.

A segunda razão para a sistematização, digamos um tanto linear, no qual organizei as ideias de Oswald, deve-se a minha tentativa de suavizar a acepção de antropofagia como crítica à filosofia do sujeito e às categorias modernas de representação. Embora reconheça que esta posição seja responsável por algumas das análises mais instigantes sobre a antropofagia, não a considero preponderante no pensamento ensaístico de Oswald.

É claro que os dilemas do pensamento moderno são um tema central para a tese. Todavia, não o abordo no âmbito das teorias da diferença ou dos atuais estudos da alteridade, das novas formas de subjetividade e do lugar do corpo no contexto da crítica às filosofias da consciência. Esse, portanto, é o segundo motivo para o arranjo mais hermenêutico e "moderno" do pensamento de Oswald na tese.

Como comentei no início, me inclino a pensar como os autores que enxergam nas ideias de Oswald traços importantes das concepções modernas na cultura contemporânea. De forma alguma, porém, isso implica algum tipo de rejeição à priori àqueles que têm renovado o pensamento antropofágico à luz das teorias pós-modernas (se me permitem o termo generalizante). Antes, minha ideia foi a de levantar argumentos para um possível diálogo.

Seria absurdo ignorar as gigantescas mudanças nos costumes, na política, nos avanços tecnológicos, nas relações com o tempo e espaço, e assim por diante. Consequentemente, não há porque negar em bloco as atuais críticas a certas concepções ultrapassadas de linguagem, de sujeito, de sociedade, de história, etc.. O que pergunto, apenas, é: quais são os reais alcances dessas mudanças, e em quais aspectos devem ser comemoradas e em quais lamentadas? Procuro desenvolver esse questionamento tendo como parâmetro discussões sugeridas pelos ensaios. 
Ao longo da tese ainda me deparei com outro problema. Se realmente desejava esmiuçar os tópicos menos conhecidos do ensaísmo oswaldiano, que peso deveria dar ao tradicional debate sobre a antropofagia e a identidade nacional? De um lado me parecia um assunto desgastado, ao qual teria pouco a acrescentar. De outro, contudo, o tema continuou sendo problema estrutural do pensamento do autor, mesmo quando se trata da análise de conjunturas distantes da realidade brasileira.

O fato é que a "filosofia antropofágica" é elaborada do ponto de vista do intelectual dos trópicos ${ }^{2}$. E, apesar de ter atenuado a presença desse vetor de interpretação tão remoído no estudo da antropofagia, não pude deixar de comentar mais detidamente o assunto.

Escrevi, então, um capítulo contextualizando historicamente algumas tradicionais contendas comuns aos intelectuais latino americanos. Procurei organizá-las em referência às ideias e à trajetória de Oswald. Naturalmente, pelo que comentamos, esse é um capítulo em que o pensamento ensaístico recua diante dos problemas mais representativos para a antropofagia modernista. Veremos no decorrer da tese, porém, como a temática local atravessa as discussões universais da "antropofagia filosófica", de forma mais destacada (nos capítulos 4 e 5) ou discreta (nos capítulos 2 e 3 ).

Por último, a tese se divide em cinco capítulos além da introdução e da conclusão. O primeiro capítulo é este ao qual acabo de me referir. Nele, exponho o cenário resumido dos problemas da origem e da originalidade do pensamento intelectual na América Latina. Convoco alguns autores brasileiros e latinoamericanos para dialogar com as posições de Oswald. Trata-se, evidentemente, de um capítulo panorâmico sobre um tema enorme. Minha ideia foi fornecer um retrato conciso de alguns tópicos implícitos na elaboração do pensamento ensaístico oswaldiano.

No segundo capítulo, debato as características do formato ensaístico em geral e na antropofagia em particular. A seguir, exponho a versatilidade com que

\footnotetext{
${ }^{2}$ Em 1945, quando começava a esboçar a antropofagia ensaística, Oswald comentou: "Diz Heidegger que toda filosofia autêntica é no seu começo imatura. A antropofagia ainda balbucia, mas propõe-se a depor no tumulto dramático de hoje. Ela leva às suas conclusões o que há de vivo no existencialismo e no marxismo. De um velho caderno que tem cerca de vinte anos tiro o seguinte: 'Pela primeira vez o homem do Equador vai falar!' "(IM, 1991, p.105).
} 
Oswald manipula o conceito de primitivo, articulando sua filosofia da história aos registros antitéticos da genealogia e da dialética.

A partir do terceiro capítulo, entro na descrição e análise das noções fundamentais dos ensaios. Aqui examino o eixo de sentido que leva do orfismo à antinomia matriarcado x patriarcado, e desta ao "homem natural tecnizado". No meio do caminho, me detenho em conceitos adjacentes, como o "direito natural", as "economias do ócio e do negócio", a "conquista do ócio", a "transformação do tabu em totem", entre outros.

O quarto capítulo discorre sobre o "ciclo das utopias". Nele trato da fulcral concepção de utopia na antropofagia, expondo quais os sentidos que Oswald confere ao termo com o intuito de questionar as relações entre o poder e o imaginário. Neste capítulo também discuto a acepção oswaldiana de humanismo.

No quinto capítulo, investigo a oposição entre Reforma e Contra-reforma no pensamento oswaldiano. Os dois conceitos são exclusivos da antropofagia ensaística, e por isso apresentam algumas diferenças importantes em relação à etapa vanguardista. Curiosamente, no entanto, este é o tema que mais se aproxima da discussão modernista sobre a cultura nacional.

$\mathrm{Na}$ conclusão, confronto o tema da falência das categorias modernas de pensamento com minha interpretação dos ensaios de Oswald. Ao mesmo tempo, procuro sugerir como a "filosofia antropofágica" ainda pode contribuir para a reflexão sobre a cultura contemporânea.

Júlio Diniz observou que a antropofagia se equilibra no trapézio da “devoração / devoção”. Nessa sutil instabilidade, o crítico antropofágico "transforma-se no tradutor de tradições incessantemente traídas pela dinâmica de uma nova relação entre sociedade, história e cultura.” (Diniz, 2009, p.3).

Concordo com Júlio que, para fazer justiça à antropofagia, é preciso desejar, de alguma forma, corromper a lógica da cópia e do modelo, submetendo a tradição às leis da invenção (inclusive a "tradição recente"). Busquei como pude renovar a interpretação da antropofagia oswaldiana, propondo olhares e contrapontos pouco usuais. Por outro lado, em nenhum momento pretendi escrever uma tese conclusiva sobre o "verdadeiro pensamento de Oswald de Andrade". 
Existem ainda muitas abordagens para os ensaios que não foram contempladas aqui. Para citar alguns exemplos, não pesquisei a obra de Hermann Keyserling, James Burnham e Earl Browder, autores que Oswald apenas menciona, mas que parecem ter servido de farol para a sua imagem de utopia. Da mesma forma, olhares psicanalíticos e etnológicos para as especulações literárias sobre o matriarcado e o patriarcado podem resultar em pesquisas criativas nos terrenos da psicologia e antropologia. Além disso, o aprofundamento histórico do pós-guerra no Brasil e no mundo, provavelmente lançaria luz em vários outros ensaios não comentados na tese, deslocando a atenção das preocupações mais generalizantes sobre a civilização ocidental, para um debate mais pontual da gestação da cultura contemporânea depois da Segunda Guerra.

É senso comum, hoje em dia, dizer que qualquer interpretação traz as marcas idiossincráticas do intérprete. Essa tese não foge a essa evidência. Leio Oswald de Andrade como uma mistura de intelectual crítico e interessado, que se negou ao sectarismo, mas não se omitiu numa presumida neutralidade.

Defendo a impossibilidade de reduzir seu pensamento paradoxal a qualquer uma das facções que chamam para si o idealismo ou a contingência, o indivíduo ou a comunidade, o perspectivismo ou o universalismo. Para mim, a antropofagia não nega, simplesmente, as dicotomias do pensamento ocidental. O que ela faz é lutar dos dois lados do ringue. Nessa tese, tento mostrar como os ensaios deslizam nesse ringue existencial, ora de forma esclarecida e original, ora de modo desajeitado; às vezes neutralizando e às vezes fortalecendo a tão odiada e adorada tradição platônica. 


\section{1 \\ Antes, durante e em torno da antropofagia: origem e originalidade na América Latina}

Qui pourrais-je imiter pour être original?

Rubén Darío

$\mathrm{Na}$ extensa bibliografia sobre a antropofagia oswaldiana são comuns as interpretações sociológicas e biográficas, fato compreensível, visto que autor e conceito misturam-se à história da literatura e da cultura brasileira. Comentei na introdução minha opção de não privilegiar esse tipo de abordagem, com o propósito de ressaltar as concepções teóricas menos conhecidas dos ensaios escritos entre 1944-54.

Apesar da ampliação do horizonte conceitual elaborada nos ensaios, não se pode dizer que os tradicionais temas da antropofagia modernista tenham sido abandonados. Na verdade, uns são aprimorados, outros descartados e alguns inteiramente transfigurados. Entre eles, o tópico da origem e da originalidade nacional persiste, variando dos tratamentos discretos aos mais taxativos.

Por conta disso, julguei ser importante escrever um capítulo que abordasse o assunto, de modo a fornecer o pano de fundo dos debates "existencialistas" com os quais iremos nos ocupar mais detidamente. As pinceladas históricas que seguem são apenas um apanhado geral. O intuito foi propor um diálogo (dentre os muitos possíveis) entre o pensamento de Oswald e a tradição literária latinoamericana. Embora seus textos praticamente não mencionem autores do continente, não é difícil encontrar inúmeras convergências de assuntos e estratégias discursivas relacionadas às conjunturas históricas semelhantes. Nesse capítulo comento algumas dessas simetrias.

A primeira delas pode ser deduzida do famoso conceito de Ángel Rama. De acordo com o autor, à sombra das cidades coloniais latino-americanas sempre existiu uma sinuosa "cidade letrada". Inicialmente ela foi formada por uma equipe 
eclesiástica que buscou ordenar o universo dos signos conforme os valores cristãos e absolutistas. Aos poucos, com o processo de secularização, civis letrados deram sequência ao trabalho.

As cidades barrocas foram internamente administradas por um séquito de intelectuais burocráticos, cuja ação doutrinadora moldou a expressão escrita da época. Eram religiosos, educadores, administradores, advogados, enfim, todos aqueles que num mundo analfabeto usavam a pena. Juntos formavam uma espécie de encanamento por onde fluíam as ordens do poder.

Como detentora do monopólio de distribuição das leis, hierarquias, classificações e da ideologia que as legitimava, a "cidade letrada" submetia as colônias ao modelo metropolitano. Ao mesmo tempo, porém, precisava manter a distância, pois quanto mais clara a diferença de sua linguagem em relação à linguagem falada, mais visível o seu poder.

Todas as sociedades, em qualquer lugar e época, controlam a produção e circulação de discurso. Muitas vezes em evidente benefício do monopólio do poder, em outras, para o bem da convivência pacífica da comunidade. Os mecanismos de controle, contudo, podem variar dos mais sutis aos mais escancarados.

No caso das cidades coloniais reinava a caricatural disparidade entre a anarquia da vida social e a forma solene com a qual escribas e burocratas tentavam enquadrá-la. Segundo Rama, havia duas fontes nitidamente distintas: a da fala cotidiana, viva, em constante metamorfose pelo contato entre os falantes de diferentes culturas; e a da fala oficial, cristalizada, artificial, reservada para as cerimonias civis, para as relações protocolares e para os demais modos de escritura. A última contaminou a reflexão artística e intelectual até as primeiras repúblicas, mas não sem alguns contratempos.

Oswald de Andrade considera o arcadismo dos Inconfidentes do século XVIII o primeiro grande assalto à "cidade letrada" no Brasil. A subversão, naturalmente, tem que ser interpretada no contexto. Os árcades mineiros tiveram sua formação intelectual na Universidade de Coimbra, onde não poderiam ter aprendido outra coisa exceto a maçante grandiloquência da poética portuguesa de então. Além disso, argumenta ele, os poetas da escola mineira tinham uma 
prioridade política. Ocupados com a independência do Brasil, não puderam se dedicar ao problema expressional e romper com o cânone árcade.

As circunstâncias, entretanto, não impediram que o sentimento de suas poesias fosse um sentimento humanizador, oposto às bajulações oficiais. Para Oswald, os Inconfidentes foram românticos avant la lettre, pois com eles já se anunciava a quebra com as prisões eruditas da tradição greco-latina. "Humanização, eis o primeiro sinal do romantismo que é também o sinal da lírica mineira. Se nela o verso é árcade, a poesia já é romântica” (AI, 1970, p. 53).

A despeito de todo o caráter localista da Inconfidência e de sua clara ligação com os interesses econômicos da classe mais abastada de Minas Gerais (descontentes com o controle fiscal da metrópole), Oswald enxergava no movimento político e no movimento literário coevo, uma ação libertadora, consciente das ideias políticas e filosóficas que agitavam a Revolução Francesa ${ }^{3}$. Afinal, questiona ele, quem eram os rebeldes? Indivíduos do mais alto escalão intelectual. Ouvidores, sacerdotes e bacharéis de Coimbra.

Ironicamente, defende a tese recorrendo à mesma premissa que os historiadores atuais aplicam para desmascarar a ficção nacionalista em torno da conspiração mineira. Ou seja, a falta de informação. Ele afirma que o "clima de romance" que envolve a rebelião, e que confunde os juízos imparciais, é resultado da obscuridade oficial que a metrópole manteve em torno do acontecimento. Entre vários exemplos, aponta as possíveis falsificações de parte da obra de Tomás Antônio Gonzaga escrita na prisão e no exílio, a qual alguns críticos chegaram a ver indícios de insanidade. "Se a apocrifia embaraça o esclarecimento da obra de Camões, que dizer dos poetas mineiros destroçados, num local apartado e longínquo, pela mão ignara da reação" (AI, 1970, p. 66). Com a distância histórica e a ausência de documentos isentos acumulam-se os equívocos.

\footnotetext{
3 Na conferência A Sátira na Literatura Brasileira, Oswald chama à argumentação as Cartas Chilenas, de autoria anônima, mas que os estudos de Afonso Arinos e Manuel Bandeira concluíram ser de Tomás Antônio Gonzaga. As Cartas Chilenas (provável referência às Cartas Persas de Montesquieu) são poemas satíricos que circularam em Vila Rica nos anos que precederam a Inconfidência Mineira. Neles, o suposto autor chileno de pseudônimo Crítilo expõe sardonicamente os abusos despóticos de um imaginário governador chileno, Fanfarrão Minésio, representação do então governador de Minas Gerais, Luís da Cunha Meneses. Para Oswald, os poemas "constituem um dos maiores momentos de nossa literatura (...) produzem a primeira consciência autonomista” (SLB, 1991, p. 74).
} 
Longe da imagem de um grupo de covardes oportunistas, Oswald irá destacar nos versos e na ação política de Gonzaga, Claudio Manuel da Costa, Silva Alvarenga e Alvarenga Peixoto, "a constelação inicial de nossa independência literária e política";

O sentimento rebenta em cada página de Marília. Não é mais musa alguma ou ninfa que os adulões de Lisboa exaltam nos seus estéreis amplexos. É a doçura de uma menina que ama. A mulher aparece ainda cercada das velhas figurações da Grécia pastoril. É nos destroços do Parnaso que surge Marilia viva, nas janelas coloniais de Vila Rica e nas naves do Aleijadinho, em meio a civilização do ouro que o Brasil significa. Gonzaga vai buscar a namorada que um século de insipidez e de anemia esqueceu nos túmulos de Camões e de Petrarca. É a namorada que se dirige para ocupar o seu grande lugar na literatura, que vem andar nos romances de Macedo e de Alencar, vem angustiar o ceticismo de Machado e vem produzir os novos "coitados d'amor" da nossa alta poesia.

Os Inconfidentes indicaram às gerações vindouras do Brasil qual o papel do intelectual nas lutas pelo progresso humano. Bastaria o sacrifício que os marcou, pela nossa democrática emancipação, para que os árcades de hoje que ousam levantar-se contra a sua memória, tivessem pudor de tamanha leviandade (AI, 1970, p. 52).

Autêntica ou forjada, o fato é que, mais de um século depois das agitações mineiras, com o país já independente, o sectarismo letrado e a escrita empolada continuavam agindo na distinção dos que tinham acesso ao poder e ao saber dos que não tinham. Muitas vezes de forma burlesca, como observou Gilberto Freyre sobre a Faculdade de Medicina da Bahia, onde "a Medicina propriamente dita se viu, por vezes, em situação de estudo ou de culto quase ancilar do da Literatura Clássica; do da elegância de dizer; do da pureza no falar; do da graça de debater questões às vezes mais de Gramática que de Fisiologia." (Freyre apud Rama, 1988, p. 44).

A "cidade letrada", de fato, ainda resistiu durante muito tempo. Contudo, a partir do impulso modernizador do século XIX em diante, as relações entre poder e expressão literária ficaram cada vez mais complexas ${ }^{4}$.

\footnotetext{
${ }^{4}$ Não há melhor exemplo para ilustrar essa complexidade do que o caso dos modernistas brasileiros de 1922. De um lado, reivindicaram autonomia criativa e reconquista da linguagem contra os cerceamentos acadêmicos; de outro, foram financiados pela oligarquia cafeeira, intimamente ligada à "República do café-com-leite" (o presidente Washington Luiz foi nada mais nada menos do que padrinho de casamento de Oswald de Andrade e Tarsila do Amaral). Conquistada e estabelecida a arte moderna, também foi comum a colaboração de escritores como
} 
No âmbito continental, à parte as singularidades políticas e econômicas que levaram aos movimentos de independência de cada país, o declínio do discurso religioso teve um papel decisivo em toda a América. Com o esmaecimento de sua função centralizadora, os intelectuais viram-se diante de constantes bifurcações que demandavam a escolha entre realismo ou idealismo; originalidade ou modelo; cosmopolitismo ou nacionalismo; passado ou futuro e daí por diante. Ainda que a organização simbólica continuasse nas mãos de uma elite alfabetizada, agora havia não mais uma, mas sempre duas respostas para a nova pergunta fundamental: qual era o melhor plano para se construir um EstadoNação moderno?

Sabemos, com Benedict Anderson, que os Estados-Nação foram "comunidades imaginadas". Isso significou, primeiramente, a transferência simbólica da soberania do reino dinástico para o Estado. Depois, a delimitação física dentro da qual a nação seria "concebida como um companheirismo profundo e horizontal" (Anderson apud Santiago, 2004 p.57), a partir da identificação étnica independente de classe social, porém, não extensiva à humanidade como um todo.

Nessas condições, o desenvolvimento do capitalismo editorial foi determinante. A circulação de livros e jornais em linguagem laica reforçou as fronteiras linguísticas e cumpriu papel crucial na homogeneização e consolidação cultural dos Estados-Nação. Tanto na Europa quanto na América divulgaram-se ideias ligadas à continuidade intemporal, aos mitos fundantes e às tradições reais ou inventadas das nações. A diferença é que na maioria dos países ricos da Europa esse processo foi concomitante a industrialização, ao passo que na América Latina os estigmas coloniais pareciam retardar o acesso à modernização.

No campo literário brasileiro, o problema tomou o seguinte rumo:

Um elemento importante nos anos de 1820 e 1830 foi o desejo de autonomia literária, tornado mais vivo depois da independência. Então, o Romantismo apareceu aos poucos como caminho favorável à expressão própria da nação recém-fundada, pois fornecia concepções e modelos que permitiam afirmar o particularismo, e portanto, a identidade, em oposição à Metrópole, identificada

Mário de Andrade, Manuel Bandeira, Carlos Drummond de Andrade, entre outros, nos projetos culturais do governo de Getúlio Vargas. 
com a tradição clássica. Assim, surgiu algo novo: a noção de que no Brasil havia uma produção literária com características próprias, que agora seria definida e descrita como justificativa da reivindicação de autonomia espiritual. (Candido, 2002, p. 20).

Para Antonio Candido o romantismo foi a primeira iniciativa programática para a elaboração de uma literatura de identidade brasileira ${ }^{5}$. Seus adeptos fincaram o marco-zero onde, supostamente, estavam nossos traços mais autênticos: na natureza e no índio. É claro que, da distância em que os via a elite letrada, ambos foram plenamente fantasiados. Também foi preciso imaginar uma História em que o colonizador não figurasse como protagonista.

É exemplar, nesse sentido, o comentário de José de Alencar sobre o processo de criação da sua peça $O$ jesuíta, de 1861, escrita para a comemoração do aniversário da independência brasileira:

Seria longo dar conta da excursão que fiz pela história pátria à busca de um assunto; basta dizer que não achei então um fato que me inspirasse o drama nacional, como eu o cogitava. Resolvi, portanto, criá-lo de imaginação, filiando-o à história e à tradição, mas de modo que não as deturpasse (Alencar apud Figueiredo, 2002, p.30).

A incoerência é indisfarçável. Tão logo assume não haver encontrado um episódio notável de heroísmo nacional, Alencar justifica-se dizendo que o inventou sem deturpação da tradição. Isto é, dá uma importância grave a algo previamente admitido como inexistente ou irrelevante. Apesar disso, como argumenta Vera Figueiredo, a aparente contradição, no fundo, reflete a consciência do autor a respeito da idealização que reveste o nacionalismo, bem como do jogo ideológico inerente às narrativas históricas. Embora seja comum a associação de seus romances à ingenuidade ufanista, segundo Vera: "Os escritos ensaísticos, bem como as notas, prefácios, pósfacios e advertências, que Alencar acrescenta aos romances, nos mostram, ao contrário, que o escritor trabalhava

\footnotetext{
${ }^{5}$ Na década de 1980, o clássico esquema de Candido (Formação da Literatura Brasileira, 1959), no qual o Romantismo é considerado pioneiro no esforço para uma literatura de cunho nacional, foi contestado e ironizado por Haroldo de Campos como equivalente a um "manual de escoteiros" (CAMPOS, 1981). Desde então, muitos críticos têm demandado um olhar menos linear e estabilizador para a história da literatura brasileira.
} 
com a relativização das fronteiras entre esses dois campos (história e imaginação)" (Figueiredo, 2002, p.24).

Isso fica patente quando lembramos que, em 1874, Alencar já antecipava um olhar sofisticado sobre a antropofagia. Em nota do romance Ubirajara, o escritor desaprova a pobreza de espírito dos cronistas do século XVI, realçando em contrapartida as nuances simbólicas do ritual. Em seguida, explora a transitividade entre perspectivismo, imaginação e realidade, requisitando que "nos transportemos, não como homens e cristãos, mas como artistas ao seio das florestas seculares, às tabas dos povos guerreiros que dominavam a pátria selvagem; e quem haverá tão severo que negue a fera nobreza desse bárbaro e tremendo sacrifício?" (Alencar, 2010, p. 102)

Entre parênteses, cabe lembrar o comentário de Raul Bopp (um dos protagonistas da antropofagia de 1928-29) ao revisar o movimento décadas depois. Segundo o poeta: "Com o retorno aos valores nativos remexeram-se os mesmos temas nacionais refundidos em poesia ociosa (...). Conseguiram apenas, deformar, reestilizar os assuntos como em século anterior haviam feito Alencar e Gonçalves Dias no famoso ciclo do Índio Romântico” (Bopp, 1977, p. 36)

Realmente, talvez haja mais proximidade entre a antropofagia e o romantismo do que se costuma mencionar. Não apenas pelo idealismo dos vanguardistas, mas também pela rejeitada consciência crítica dos românticos. Entretanto, com toda diferença de figurino, ambos os movimentos representaram tentativas de emancipação cultural, pela mescla de diálogo e crítica ao pensamento europeu. Além disso, nos dois casos, as figura do índio (Cavalheiro ou Canibal) diz mais da estratégia do que da realidade, pois reivindicava, antes de qualquer coisa, uma deliberada mudança no modo de enxergar o mundo.

Pois bem, retomando o fio da meada, contra o "olhar artístico" para as qualidades nativas, opôs-se frontalmente a corrente de liberais civilistas. Estes defendiam a elaboração do Estado Soberano guiada pela "luz da razão". $\mathrm{Na}$ conjuntura latino-americana, a dualidade ganhou seu paradigma no célebre livro de Domingos Sarmiento, "Facundo ou Civilização e barbárie” de 1845. Nele, o confronto se apresenta como uma escolha entre o avanço civilizador nos padrões 
europeus ou o caudilhismo bárbaro de líderes como Juan Manuel de Rosas e Juan Facundo Quiroga ${ }^{6}$.

Mais uma vez, a afirmação acima só pode ser feita num sentido abrangente, já que os processos de independência e modernização responderam às idiossincrasias particulares de cada região. ${ }^{7}$ Em termos simbólicos, porém, o tópico "civilização x barbárie" marcou a reflexão cultural de toda a América Latina na época, modulando-se nas tensões entre nacionalismo/cosmopolitismo, original/cópia e passado/futuro.

Mais adiante, essa antinomia importaria as teorias positivistas e seus diagnósticos pseudo científicos sobre os males endêmicos do continente. Agregou-se a discussão o argumento de que o atraso civilizatório (entre eles a incapacidade dos escritores de serem originais) era fruto da mistura de raças inferiores e superiores e do clima impróprio. Com isso, uma elite intelectual cientificamente preparada deveria conduzir de cima para baixo uma ação política que tentasse reparar os danos de uma situação, no fundo, destinada ao fracasso.

Nesse debate, merece destaque o trabalho do escritor brasileiro Manuel Bonfim. Ainda que inevitavelmente preso ao vocabulário de sua época, no livro América Latina, males de origem, Bonfim se utilizou das metáforas cientificistas para defender a tese de que o atraso latino-americano não era o fruto da raça ou do meio, mas da relação parasitária da Europa com o continente, que se mantinha intacta desde a colonização. "Era uma colônia vassala; é hoje uma colônia independente". (Bonfim, 2008, p.175)

Defendendo métodos diferentes para a recuperação da "saúde" do continente, Bonfim rompeu com as malhas ideológicas do positivismo a partir do

\footnotetext{
${ }^{6}$ Juan Manuel José Domingo Ortiz de Rozas y López de Osornio (Buenos Aires, 1793 Southampton, Hampshire, 1877) foi um militar e político argentino, governador da Província de Buenos Aires. Foi o principal dirigente da chamada Confederação Argentina (1835-1852). Juan Facundo Quiroga (1788, La Rioja - 11 de setembro de 1888, Córdoba) foi um influente caudilho argentino, governador provisório da Província de La Rioja.

${ }^{7}$ No Brasil, a linha divisória entre os antigos hábitos coloniais (barbárie) e as novas convenções burguesas (civilização) era mal traçada e comumente os canais se misturavam. Segundo Roberto Schwarz: "a convivência familiar e estabilizada entre concepções em princípio incompatíveis esteve no centro da inquietação ideológico-moral do Brasil oitocentista. A uns a herança colonial parecia um resíduo que logo seria superado pela marcha do progresso. Outros viam nela o país autêntico, a ser preservado contra imitações absurdas. Outros ainda desejavam harmonizar progresso e trabalho escravo, para não abrir mão de nenhum dos dois, e outros mais consideravam que esta conciliação já existia e era desmoralizante.” (SCHWARZ, 1987, p.25).
} 
seu interior. Por exemplo, quando viu na promoção da educação popular e no rompimento com a excessiva hierarquização do saber, fatores determinantes para a conformação orgânica de uma nação independente.

Em particular, um dos grandes méritos de Bonfim foi o de sustentar, na contramão da época, que nem sempre a neutralidade era o meio mais correto de formular um determinado problema. Muitas vezes, ela era apenas um jeito de mascarar preconceitos e interesses velados. Bonfim pode ser considerado um dos pioneiros no estilo que, mais tarde, seria explorado por autores como Gilberto Freyre, Fernando Ortiz e o próprio Oswald de Andrade:

Vem aqui a exposição de uma teoria, construída com os fatos e as deduções como no-los apresenta a ciência; na linguagem geral do livro, porém, certos comentários, parecerão descabidos ou impróprios a uma demonstração que assim se fundamente. Seria preciso, acreditam certos críticos, uma forma impassível, fria e impessoal; para tais gentes, todo o argumento perde o caráter científico sem esse verniz de impassibilidade; em compensação, bastaria afetar imparcialidade para ter direito a ser proclamado - rigorosamente científico. Pobres almas!... Como seria fácil impingir teorias e conclusões sociológicas, destemperando a linguagem e moldando a forma à hipócrita imparcialidade, exigida pelos críticos de curta vista!... Não; prefiro dizer o que penso, com a paixão que o assunto me inspira; paixão nem sempre é cegueira, nem impede o rigor da lógica. (...). A paixão da linguagem, aqui não dissimulada, traduz a sinceridade com que essas coisas foram pensadas e escritas. (Bonfim, 2008, p.3)

Como Manuel Bonfim, embora de forma mais tênue, Os Sertões de Euclides da Cunha é um notório exemplo do desgaste do padrão binário que vinha conduzindo os intelectuais latino-americanos pela modernidade. Meio século depois de Sarmiento propor que a cidade se impusesse sobre o campo, como único trajeto possível para a fonte civilizatória europeia, Euclides, partidário deste projeto, vacila diante do lado hediondo da modernização exibido na Guerra de Canudos: "vivendo parasitariamente à beira do Atlântico dos princípios civilizadores elaborados na Europa, e armados pela indústria alemã — tivemos na ação um papel singular de mercenários inconscientes". (Cunha, 2000, p. 5) ${ }^{8}$. Cada

\footnotetext{
${ }^{8}$ Ressalvando suas conclusões éticas, às quais chegou a classificar de "ufanismo acadêmico e cruel" (SI, 1991, p. 197); Oswald considerava Euclides um "caminho solar" em comparação à "sociologia estatística" norte-americana em voga na década de 1940. Para ele, no desfecho da Segunda Guerra, a atualidade de "Os Sertões" extravasava sua importância para toda a América
} 
um a sua forma, os dois autores são exemplos emblemáticos da crescente conscientização daqueles intelectuais de que realidade e teoria vinham dançando músicas diferentes. Formava-se a atmosfera propícia para o modernismo.

Nas primeiras décadas do século $\mathrm{XX}$, as principais cidades latinoamericanas começaram a ganhar traços mais acentuados de urbanidade. Em sua autobiografia, Oswald pontua as lembranças infantis com as imagens dessa tateante modernização: "Um mistério esse negócio de eletricidade. Ninguém sabia como era. Caso é que funcionava. Para isso as ruas da pequena São Paulo de 1900 enchiam-se de fios e de postes" (HSP, 1976, p.34).

Também era mais rotineira a presença do imigrante, assim como as viagens de escritores e das classes altas para a Europa. Vale lembrar que PauBrasil foi escrito em Paris. Não à toa, décadas depois, Oswald diria: "Se alguma coisa eu trouxe de minhas viagens à Europa dentre duas guerras, foi o Brasil mesmo". (PL, 1994, p. 111). O panorama cultural e urbano se transformava, trazendo impactos subjetivos cada vez mais rápidos nos intelectuais, que experimentavam um cosmopolitismo menos abstrato e ingênuo ${ }^{9}$.

Ademais, cresciam de mãos dadas o número de cidadãos alfabetizados e a circulação de livros, jornais e revistas, fenômeno que atingiu em cheio o coração da "cidade letrada". Sem que desaparecesse o pedantismo acadêmico, a vida intelectual foi se intensificando e se descentralizando com o aumento no número de participantes, escritores ou leitores. Os debates políticos e literários ganharam as ruas, embalados pela vida boêmia. De acordo com Ángel Rama, estes novos jornalistas/intelectuais eram autodidatas, consumidores da literatura que se produzia no seu próprio tempo. Com eles, as ideias perdiam as rígidas filiações e multiplicavam as referências.

Latina: "não podemos ser mercenários inconscientes dos imperialismos anunciados no roldão do conflito. Sobretudo mercenários contra nós mesmos.” (FS, 2002, p. 122)

${ }^{9}$ Buenos Aires constituiu um caso a parte. Da metade do século XIX à metade do século XX, foi o segundo maior destino de imigrações de europeus no mundo, e assistiu a um surto urbanista sem precedentes na América do Sul. Ao estilo benjaminiano, Beatriz Sarlo descreveu o clima do cosmopolitismo emergente na cidade: "Buenos Aires ha crecido de manera espectacular en las dos primeras décadas del siglo XX. La ciudad nueva, hace posible, literariamente verosímil y culturalmente aceptable al flaneur que arroja la mirada anónima del que no será reconocido por quienes son observados, la mirada que no supone comunicación con el otro (SARLO, 1996, p. 16) 
Los positivistas podían discutir con los liberales románticos y con los católicos conservadores, pues compartían el mismo discurso de las ideas. Con estos nuevos no podían hacerlo, pues solo les ofrecían la posibilidad de co-sentir con ellos. De ahí surge la oposición generalizada en que resultan agrupadas fuerzas entre si adversas: los retrasados románticos, los conservadores, los liberales, las viejas fuerzas del orden, pero también los positivistas y racionalistas, el grueso de los ilustrados que en la medida en que se habían consagrado a una tarea educativa en beneficio de las jóvenes generaciones, sintieron el fracaso y la traición: Silvio Romero, José Verissimo, Calixto Oyuela coinciden en la alarma (Rama, 1985, p. 44-45).

O periodismo está intrinsecamente ligado à gestação da linguagem modernista latino-americana. Estilizando a política e politizando a arte, os jornais não só serviram como campo de batalha cultural, mas também foram o ganha-pão de muitos escritores que viravam as costas para a "cidade letrada". Segundo Oswald, "o Correio Paulistano foi o jornal dos revolucionários da literatura. Nele começaram Menotti del Picchia, Plinio Salgado, Cassiano Ricardo, Osvaldo Costa e Hermes Lima. Mário de Andrade e eu tivemos aí nossa fortaleza"(Andrade, 1996, p. 230)

Alguns anos antes, a atuação de Rubén Darío no periódico argentino $L a$ Nación virou um modelo para a época. Darío foi o porta-voz da sua geração e ganhou a reputação de "príncipe das letras castelhanas". Para além da habilidade como escritor, seu grande feito foi urdir a transmutação da imagem do escritor letrado para a do escritor artista, pela apologia da aristocracia do talento.

Por meio de vários ensaios publicados no jornal (e mais tarde reunidos no livro Los Raros), Darío divulgou a obra e a vida de autores modernos como Poe, Lautréamont, Verlaine e Ibsen, delineando a estética, os gestos e as ideias da nova aristocracia artística. O programa do autor sugeria critérios inéditos e pouco óbvios para uma hierarquização por talento. Como explica Mónica Bernabé, os textos formam uma sala de espelhos no qual se refletem, mutuamente, tipos degenerados, visionários, anarquistas, redentores e etc. "Lista de artistas, laberinto de tópicos, simultaneidad de estéticas, muestra del caótico mundo moderno, dentro del cual es posible extraer poesía, pensamiento, figuras" (Bernabé, 2006, p.41)

Na América Latina, portanto, foi no início do século XX que floresceu de vez o estado de espírito ambivalente que caracterizou a modernidade europeia. 
Aquilo que Octavio Paz chamou de "paixão crítica", que se nega duplamente: como paixão e como crítica. Entrando as décadas, o caldo cultural engrossou e entornou na miscelânea dos manifestos, polêmicas, experimentações e rupturas. A ampliação do panorama intelectual para além dos determinismos e conservadorismos letrados não impediu, todavia, que as vanguardas latinoamericanas atravessassem a primeira metade do século XX martelando velhas contradições.

Não existe uma unidade coesa entre as inúmeras vanguardas do continente. As agitações foram variadas e desconexas e, vistas em conjunto, lembram um "mosaico de paradoxos", como sugeriu Alfredo Bosi (Bosi In: Schwartz, 1995, p. 19). Para piorar, a definição também se encaixa individualmente a alguns de seus principais representantes, em função das mudanças repentinas que experimentaram nas próprias carreiras.

Apesar disso, não se pode negar uma linha relativamente comum a todos: o problema do valor de suas originalidades diante do prestígio dos modelos europeus. Se quisermos ser precisos, a urgência de ruptura com a tradição foi o grande mote das vanguardas no mundo inteiro ${ }^{10}$. Contudo, na América Latina, quase sempre esse conflito veio acompanhado do ranço da questão colonial.

Se o dilema era antigo, as soluções eram novas. Agora a disputa ocorria no interior da linguagem. Ao atacarem as convenções letradas, repudiando as coordenadas realistas e românticas da representação, as vanguardas liberaram o imaginário para sondagens inusitadas sobre os problemas da origem e da originalidade. A liberdade estética traz consigo o bônus da ambiguidade, do paradoxo e da ironia. Vantagens imediatamente assimiladas por escritores como Oswald e Borges. Este último não cansou de alfinetar os clichês nacionalistas. Em uma dessas ocasiões, comentou que a maior prova de que o Alcorão fora escrito por um árabe era a ausência de camelos no texto, pois "um falsário, um turista, um nacionalista árabe, a primeira coisa que teria feito seria prodigar camelos".

${ }^{10}$ Octavio Paz cunhou o conceito de "tradição da ruptura" para referir-se à arte moderna. A tradição da ruptura nega não só a tradição, mas também a ruptura. Com isso o autor quer enfatizar que os artistas modernos rompem também com o hábito da interrupção, buscando outras continuidades ao eleger tradições mais antigas: "Lo viejo de milenios también puede acceder a la modernidad: basta con que se presente como una negación de la tradición y que nos proponga otra. Ungido por los mismos poderes polémicos que lo nuevo, lo antiquísimo no es un pasado: es un comienzo". (PAZ, 1981, p. 5) 
Apenas para concluir que os argentinos poderiam "se parecer mais com Maomé, e acreditar na possibilidade de ser argentinos sem exagerar na cor local" (Borges In: Schwartz, 1995, p. 466)

Com Oswald, o nacionalismo exótico de "cor local" foi apelidado de "macumba para turista". Em seu lugar, a antropofagia ofereceu uma releitura do nacional via renovação estética, sem exclusão (mas com seleção) das influências estrangeiras. A variedade de propostas foi sintetizada no clássico dilema antropófago: "Tupi or not tupi, that's the question".

Apesar de muito diferentes, as obras de Oswald e Borges tornaram-se protótipos de como se descentrar, na mesma tacada, nacionalismo e cosmopolitismo. Aliás, com os dois, é a própria ideia de origem que sofre os mais perturbadores deslocamentos. Escavando a sombra da tradição, relativizando o sentido e o valor da originalidade, ambos rescrevem a História a partir de suas dobras.

Nunca é demais lembrar de Pierre Menard, autor de Quijote de Borges. O inclassificável "conto-ensaio", no qual uma espécie de crítico-narrador enaltece um obscuro autor francês, que teria literalmente reescrito alguns capítulos do clássico de Cervantes, sem tirar nem por uma vírgula. Em meio à descrição do feito, o narrador comenta que "Cervantes podia se dar ao luxo do espontâneo", salientando a precisa diligência do artesão em oposição à pusilanimidade da ideia de inspiração, sobre a qual se sustenta a moderna noção de arte. Por fim, cita uma carta do tal Menard, na qual este afirma que:

Pensar, analizar, inventar (me escribió también) no son actos anómalos, son la normal respiración de la inteligencia. Glorificar el ocasional cumplimiento de esta función, atesorar antiguos y ajenos pensamientos, recordar con incrédulo estupor que el doctor universalis pensó, es confesar nuestra languidez o nuestra barbarie. Todo hombre debe ser capaz de todas las ideas y entiendo que en el porvenir lo será. (Borges, 2012)

O conto foi publicado em 1944 e ilustra o amadurecimento do debate. Repare que Borges corrompe o modelo canônico sem precisar tocá-lo, demonstrando a contingência das valorações e a influência da perspectiva. $\mathrm{O}$ 
leitor, desorientado, fica sem saber aonde termina a ironia e começa a mensagem séria.

Poucos anos antes, de forma bem menos satírica, mas igualmente notável, o escritor cubano Fernando Ortiz sugeria outra corruptela das noções de origem e original pelo conceito de transculturação. O livro El cantrapunteo cubano del tabaco e del azúcar é um marco na mudança das abordagens de raça, cultura e povo nos estudos sociais e antropológicos. Malinowski comparou-o a uma "rosa dos ventos", devido aos numerosos caminhos que sugeria para interpretação cultural.

$\mathrm{Na}$ época o autor propôs a substituição do conceito em voga de aculturação pelo de transculturação, chamando a atenção para as reais dimensões do fortuito nas permutas entre culturas diferentes.

Por aculturación se quiere significar el proceso de tránsito de una cultura a otra y sus repercusiones sociales de todo género. Pero transculturación es el vocablo más apropiado. Hemos escogido el vocablo transculturación para expresar los variadísimos fenómenos que se originan en Cuba por las complejísimas transmutaciones de culturas que aquí se verifican, sin conocer las cuales es imposible entender la evolución del pueblo cubano, así en lo económico como en lo institucional, jurídico, ético, religioso, artístico, lingüístico, psicológico, sexual y en los demás aspectos de su vida. La verdadera historia de Cuba es la historia de sus intrincadísimas transculturaciones. (Ortiz, 1978, p.93)

Ortiz argumenta que qualquer povo é fruto de transculturações que alteraram, reciprocamente, antigas culturas em contato. No caso de Cuba, porém, a constelação de etnias em convívio parecia-lhe um fenômeno que sobrepujava qualquer outro em importância histórica. Ele lembra que os próprios ibéricos eram resultado de recente transculturação mediterrânea, e já chegaram à América espelhando várias mentalidades diferentes (mercantil, feudal e até protoindustrial). Mas nada que se comparase a babel formada por "ciboney, taino, español, judío, inglés, francés, angloamericano, negro, yucateco, chino y criollo (...) esas continuas, radicales y contrastantes transmigraciones geográficas, económicas y sociales de los pobladores, esa perenne transitoriedad de los propósitos" (Ortiz, 1978, p. 94) 
Em estilo ensaístico, o autor expõe a historia colonial cubana pela dialética do tabaco e do açúcar. Os dois produtos nacionais por excelência viram metáforas do jogo de forças que perpassa o processo de colonização. O açúcar é técnica, energia, virtude e veio de fora da América; o tabaco é magia, inspiração, malícia e foi levado daqui. O pujante contraponto cultural, porém, termina quando entra em jogo a máquina a vapor. Com ela, desfazem-se os contrastes e aplanam-se as diferenças.

As afinidades entre o livro de Ortiz e os ensaios de Oswald são significativas. Os dois se apoiam em conceitos (transculturação/antropofagia) que anarquizam a lógica das identidades fixas; constroem suas reflexões sobre um esquema dialético e metafórico (tabaco x açúcar/ matriarcado x patriarcado); e rescrevem a História a partir de um olhar holístico e de uma linguagem literária.

Não bastasse isso, Ortiz ainda lança a pergunta: "Ya en las postrimerías del siglo XV, al abrirse la Edad Moderna, ¿no comenzó ésta con el descubrimiento de un Nuevo Mundo por los blancos de Europa?" (Ortiz, 1978, p.24). Ora, a mesma frase será dita por Oswald, só que com um ponto de exclamação. Entre outras razões, porque, para ele, o aparecimento da América no mapa representou um trauma irreparável no sentido de unidade cosmológica do Ocidente.

Como Ortiz, Oswald estava interessado nas transculturações entre os dois mundos que se chocavam. Todos nós imaginamos a radicalidade da transformação na percepção do tempo e do espaço do autóctone ameríndio. A maioria vivia no mundo de lendas da tradição oral. O futuro era um assunto para os deuses, e não existia algo como uma História a ser construída.

Entretanto, do outro lado da moeda as coisas também não se mantiveram como antes. Para Oswald, naquele período de revoluções, tão importante quanto o renascimento, a reforma ou a nova ciência é a descoberta do homem nu e sem pecado. A aparição do primitivo, no século $\mathrm{XV}$, "seria como se, nos nossos dias, surgisse na terra um grupo de habitantes de Marte" (OA, 1991, p.251). Do outro lado do mundo existia o homem sem lei, sem fé e sem rei; alheio ao céu e ao inferno; vivendo do ócio no paraíso terrestre das selvas americanas. 
Até então, a pluralidade do mundo se reunia na palavra sagrada. Substância e acidente, razão e revelação, tinham um princípio de identidade. A aparição do Novo Mundo abalou o "egocentrismo ptolomaico" europeu e alimentou a lógica oposta, isto é, a da multiplicidade, simbolizada na mestiçagem.

Como vimos com Ortiz, espanhóis e portugueses já chegaram à América trazendo uma bagagem transcultural recente. Para Oswald, inclusive, o fato de ser um povo mestiço foi causa decisiva para o impulso desbravador do ibérico. A mestiçagem, idealizava ele, "trazia em si a capacidade milenária da insubmissão" (LI, 1991, p.186).

A América, então, não inventou a miscigenação, mas foi o terreno apropriado para a sua proliferação. A colônia foi o espontâneo desvio do modelo platônico-cristão europeu. Por isso, Oswald negava a descendência direta entre Barroco e Renascimento. "O Barroco. O estilo utópico. Nasceu com a América. Com a descoberta. Com a utopia" (DA, 1970, p.227). Segundo ele, tratava-se de uma plástica vinda do mundo colonial, entre "flores, lianas e frutos disformes" (Ibidem).

De modo semelhante, por volta da década de 1950, uma ampla caracterização do barroco americano passou a ser utilizada por diversos escritores como síntese trans-histórica de nossa estética híbrida e mutante. O "neobarroco", como o definiu Severo Sarduy ${ }^{11}$, descrevia a tendência da arte latino-americana para a incorporação de influências culturais diversas como uma habilidade particular. De quebra, fornecia uma imagem unificada do continente.

Lezama Lima apelidou o barroco americano de "arte da contraconquista", estendendo seu significado para o de estratégia discursiva. Para ele, linguagem e imaginação eram entendidas, metaforicamente, como as matérias primas (o barro), a partir da qual se moldava uma nova visão da História: "uma técnica da ficção seria imprescindível quando a técnica histórica não possa estabelecer o domínio

\footnotetext{
${ }^{11}$ Refiro-me ao primeiro momento do conceito de Sarduy. Pois, como pontuou Rodrigo Labriola, "O neobarroco de Sarduy iria ganhar nos anos 80, a partir de outros dois ensaios intitulados La simulación (1982) e Nueva inestabilidad (1987), uma maior complexidade capaz de entrar em relação com as diversas manifestações da crise da modernidade. E é esse último «modelo barroco» o que vai se conectar, pois, com o mundo cultural e político da chamada pós-modernidade - e que, em nosso campo disciplinar, será contemporâneo das mudanças e fragmentações dos estudos literários nas universidades" (LABRIOLA, 2008)
} 
das suas precisões. Uma obrigação quase de voltar a viver o que já não se pode precisar" (Lima, 1988, p.55).

Lezama teoriza sobre a forma como aqueles escritores utilizavam a história para a transformação da realidade cultural, bem como a inclinação comum para as interpretações abrangentes, literárias e poéticas dos acontecimentos passados. Interpretações dialéticas que enxergavam nos fatos históricos embates subliminares entre polos ideológicos antagônicos (Tabaco x Açúcar/ Matriarcado x Patriarcado / Conquista x Contraconquista / Barroco x Classicismo).

É digna de nota a influência de Eugênio d'Ors e de sua interpretação do movimento Barroco. Se por um lado é irônico que um escritor espanhol tenha sido fonte para a definição de uma possível autenticidade latino-americana; por outro, isso indicava superação do ressentimento colonial. Alejo Carpentier resume as teses de d'Ors descrevendo o barroco como uma espécie de força criadora, de "espírito", mais do que um mero estilo histórico. Ao opor o Barroco ao Classicismo, a maneira da dicotomia entre o apolíneo e o dionisíaco de Nietzsche, ele explica que: "Existe um Barroco como constante do espírito que se caracteriza pelo horror ao vazio, à superfície nua, à harmonia linear-geométrica (...) quer dizer, uma arte em movimento, que parte de um centro e vai para fora, rompendo de certa forma seus próprios limites" (Carpentier, 1987, p.113).

A afinidade desta disposição de espírito com a América Latina viria "da consciência de ser outra coisa, de ser uma coisa nova, ser uma simbiose, de ser um crioulo; e o espírito crioulo já é por si mesmo um espírito barroco". (Carpentier, 1987, p.121)

Lezama Lima também cita d'Ors ao defender a ideia de que existe uma imaginação barroca, assim como pode se pensar numa imaginação etrusca, numa carolíngia, numa bretã etc. É sobre a "tapeçaria de uma dessas eras imaginárias que o fato ganha realidade e gravitação" (Lima, 1988, p.57). Na América, o barroco é a arte da "contraconquista" pela qual ela "trança e multiplica a linguagem ao desfrutá-la”. (Lima, 1988, p.80)

É curioso observar que, na mesma época, Oswald percorreu trajeto similar, e chegou a uma conclusão muito próxima a da "contraconquista". Na sua versão, a trama passou pela reconciliação com os jesuítas portugueses e pela identificação 
da Contra-Reforma como visão de mundo congênere do matriarcado. Assim, a verdadeira Contra-Reforma teria sido a do comunismo jesuíta, do sincretismo religioso, da mestiçagem e da cordialidade brasileira:

Um escritor, um sociólogo, um crítico podem rotular, numa ampla latitude ideológica, um fenômeno que parecia restrito a certos compromissos de origem ou de destino. Assim, Eugenio d'Ors, no seu livro clássico sobre o barroco admirável lição de história e de crítica -, coloca dentro do conceito de barroco as coisas mais estranhas e longínquas. Rubens para ele é barroco, talvez por ter sido católico. Como barroco são Bach e Mozart e até a tauromaquia

Quando falo em Contra-Reforma, o que eu quero é criar uma oposição imediata e firme ao conceito árido e desumano trazido pela Reforma e que teve como área cultural particularmente a Inglaterra, a Alemanha e os Estados Unidos da América. Ao contrário, nós brasileiros, campeões da miscigenação tanto da raça como da cultura, somos a Contra-Reforma, mesmo sem deus ou culto. Somos a utopia realizada, bem ou mal, em face do utilitarismo mercenário e mecânico do norte. Somos a caravela que ancorou no paraíso ou na desgraça da selva (MU, 1970, p.166)

As concepções oswaldianas de Reforma e Contra-Reforma serão o tema do quinto capítulo. No momento, gostaria apenas de chamar a atenção para a pitada anti-imperialista anunciada no excerto acima. Esta foi incorporada à antropofagia de 1944- 1954, mas é incipiente (ou mesmo inexistente) na versão modernista. O tempero, na verdade, surge nos anos 1930, quando Oswald embarcou numa outra via do modernismo latino-americano que ainda não comentamos: a estética da revolução.

Desde os anos 1920, uma ala marcante das vanguardas teve como tema a revolução comunista. Dela fizeram parte artistas e intelectuais tão importantes como César Vallejo, Pablo Neruda, Diego Rivera, José Carlos Mariátegui, entre outros que, com todas as suas diferenças, se inclinaram para a "arte engajada". Como nas outras polêmicas modernistas (e misturado a elas) esse debate foi volúvel e permeado de questões regionais. Não obstante, a contenda estético/ideológico incidiu sobre todo o continente ao menos até a década 1970.

No mundo convulso que precipitaria a Segunda Guerra mundial, alguns artistas viam no compromisso com a revolução política uma questão cada vez mais urgente. A arte deveria expressar mudança de mentalidade social, mais do 
que a pura conquista formal. Por outro lado, qualquer subjetivismo parecia o mero reflexo da decadência burguesa.

Não era exatamente fácil discernir as categorias de arte. Dizia Mariátegui que "A decadência e a revolução, assim como coexistem no mesmo mundo, coexistem também nos mesmos indivíduos. (...)” (Mariátegui In: Schwartz, 1995, p. 441). Daí a profusão de estudos paradoxais que tentavam explicar como conciliar liberdade estética e compromisso revolucionário. Diga-se de passagem, tentativas inglórias.

Para os artistas mais criativos o problema foi dilacerante. Como submeter a livre imaginação a um filtro estreitamente político? Vallejo, que nadou nesses mares contraditórios, descreve com grande presença de espírito uma cena na qual passeava com um intelectual revolucionário, quando ouviram um piano tocando uma partitura desconhecida por ambos. Ao terminar a música, Vallejo desafiou: "responda rápido se esta música é revolucionária ou reacionária, classista ou socialista, proletária ou burguesa?" Daí pra frente ele detalha o desespero do ortodoxo em dar a opinião errada: “(...) e se fosse um artista famoso, considerado pela crítica marxista como revolucionário? (...) vacilou, esquivou, em suma, acabou se engolfando em textos, opiniões e citações de Hegel, Marx, Bukharin, entre outros" (Vallejo In: Schwartz, 1995, p. 452).

Em síntese, mais do que qualquer coisa, era preciso escolher e declarar o voto: contra ou a favor da revolução. Como sabemos, Oswald escolheu. Renegou o passado experimentalista e foi fazer arte engajada. Defendeu a Rússia e Stalin. Escreveu romance proletário, teatro de tese e durante 15 anos tentou ser "casaca de ferro na Revolução Proletária".

Entrou para a história da literatura brasileira o "anti-prefácio" que escreveu em 1933 para o lançamento de Serafim Ponte Grande (considerados por muitos sua melhor obra de ficção). Nele, em meio à crítica à sociedade brasileira e à autocrítica, não deixa pedra sobre pedra do modernismo, que chega a ser retratado como "intelectuais brincando de roda". A antropofagia vira um "sarampão" e a poesia Pau-Brasil uma manobra imperialista, como a valorização do café. Tudo 
isso para anunciar o livro (ou, nas suas palavras, o "epitáfio") que era o resultado maduro de uma década de pesquisa estética ${ }^{12}$.

A abrupta mudança de Oswald seguia uma tendência continental. A crise de $1929^{13}$ espalhou um profuso questionamento político e ideológico, ao qual se juntou as esperanças lançadas pela Revolução Russa. Paralelamente, enquanto o fascismo crescia na Europa, no Brasil surgia o Estado-Novo ditatorial. Por fim, uma ala dos intelectuais e artistas de vanguarda não podia mais ignorar um dado óbvio: a débil modernização latino-americana não tinha incidência sobre a população, a democracia era restrita à elite, e a maioria das pessoas era simplesmente analfabeta. Diante dessa constatação, foi comum o pudor em relação à "arte-pela-arte".

Apesar disso, comentando sobre a ideologia dos artistas desse "segundo momento modernista", Octavio Paz diz que:

El antiimperialismo de los modernistas no estaba fundado en una ideología política y económica, sino en la idea de que la América Latina y la América de lengua inglesa representan dos versiones distintas y probablemente inconciliables de la civilización de Occidente. Para ellos el conflicto no era una lucha de clases y de sistemas económicos y sociales, sino de dos visiones del mundo y del hombre. (Paz, 1981, p. 61)

A observação de Paz sugere um traço comum à estética revolucionária de 1920-30 e às articulações posteriores do neobarroco latino americano e da ContraReforma oswaldiana. Em graus diferentes, todos esses casos apontam para reconciliações com a herança ibérica (ou latina), seguidas de uma transferência da "angústia da influência" para as tensões com o imperialismo anglo-saxão.

Seria essa a principal constante do pensamento cultural latino-americano? Ou seja, muda-se o modelo, mas mantém-se a dinâmica? E o que dizer de princípios identitários tão heterônomos como a mestiçagem, o barroco, o

\footnotetext{
${ }^{12}$ Vinte anos depois, em uma entrevista, Oswald faz uma pequena mea-culpa da mea-culpa: "Em 1930, arriamos a bandeira. É que surgiram o que eu chamo os "Búfalos do Nordeste", trazendo nos cornos a questão social. Arriamos a bandeira, esmagados por uma espécie de sentimento de culpa (...). Não éramos capitalistas. Nem eu nem Mário éramos industriais. Mas sofríamos a ambiência"(DD,1990, p. 222)

${ }^{13}$ Um detalhe biográfico: o crack da bolsa de Nova York estremeceu a confortável situação financeira de Oswald de Andrade, herdeiro de um abastado fazendeiro de Minas Gerais. Fato que, se não determinou, provavelmente ajudou em seu mergulho comunista.
} 
trasculturalismo e a antropofagia? Não passavam de variáveis do inconformismo intelectual diante de realidades históricas e culturais que remetiam frequentemente às marcas da submissão colonialista/imperialista?

Creio que só à custa de um reducionismo grosseiro poderíamos limitar a variedade dos autorretratos latino-americanos a um complexo de inferioridade generalizado. Tal simplificação teria que ignorar o fato de que as identidades nacionais foram problemáticas em qualquer lugar do mundo ${ }^{14}$. Em parte por que o próprio conceito de nacionalismo, como todo legitimo filho da modernidade, é uma noção paradoxal por si. Como explicou Immanuel Wallerstein, "os nacionalismos do mundo moderno são a expressão ambígua de um desejo por... assimilação no universal... e, simultaneamente, por... adesão ao particular, à reinvenção das diferenças. Na verdade, trata-se de um universalismo através do particularismo e de um particularismo através do universalismo" (Wallerstein, 1984, p. 166-7).

A modernidade nasce à época da expansão marítima. Desde seu princípio o capitalismo tem uma tendência mundializante. A dialética mundial/local faz parte do espírito do tempo moderno.

Hoje em dia comenta-se o declínio dessa lógica, diluída na homogeneização cultural enredada pelas tecnologias virtuais e pela economia globalizada. Com todas as controvérsias que o tema suscita, não se pode negar que a obsessão pelas identidades nacionais perdeu a pujança de outrora e cedeu terreno a outros modos de identificação cultural.

Talvez, então, seja um bom momento para reler a tradição literária latinoamericana com novos olhos ("com olhos livres", como queria Oswald).

\footnotetext{
${ }^{14}$ Stuart Hall comenta da seguinte forma o exemplo da Grã-Bretanha: “A maioria das nações consiste de culturas separadas que só foram unificadas por um longo processo de conquista violenta - isto é, pela supressão forçada da diferença cultural. "O povo britânico" é constituído por uma série desse tipo de conquistas - céltica, romana, saxônica, viking e normanda. Ao longo de toda a Europa, essa estória se repete ad nauseam. Cada conquista subjugou povos conquistados e suas culturas, costumes, línguas e tradições, e tentou impor uma hegemonia cultural mais unificada. Como observou Ernest Renan, esses começos violentos que se colocam nas origens das nações modernas têm, primeiro, que ser "esquecidos", antes que se comece a forjar a lealdade com uma identidade nacional mais unificada, mais homogênea. Assim, a cultura "britânica" não consiste de uma parceria igual entre as culturas componentes do Reino Unido, mas da hegemonia efetiva da cultura "inglesa", localizada no sul, que se representa a si própria como a cultura britânica essencial, por cima das culturas escocesas, galesas e irlandesas e, na verdade, por cima de outras culturas regionais" (HALL, 1992, p.16)
} 
Principalmente aquela linhagem de "formação indisciplinada" 15 , que ousou arrombar os templos da "cidade letrada" e transgredir seu vernáculo. Para estes autores, o câmbio entre universal e local nunca esteve estabilizado. Seus esforços constantes disseminaram a ressignificação de ambos os polos da dicotomia. Os resultados foram os projetos galácticos, enciclopédicos, cosmológicos, tentaculares, dialógicos de autores tão diferentes como Borges, Lezama Lima, Octavio Paz, Alejo Carpentier, Haroldo de Campos, Severo Sarduy, Fernando Ortiz, Mário de Andrade, Gilberto Freyre, entre outros. Neles, o dilema da origem e da originalidade nacional é invadido pela imaginação literária, metamorfoseado em inúmeras controvérsias novas, de múltiplos pontos de vista.

Seria tentador concluir dizendo que os ensaios de antropofagia filosófica se filiam a essa tendência. Mas com isso não estaríamos confinando mais uma vez os escritores latino-americanos em um mesmo e totalitário princípio de interpretação?

O que pretendo nos próximos capítulos é uma abordagem franca da filosofia oswaldiana. Gostaria de pensar sobre seus questionamentos a respeito do homem, da cultura e do poder no painel existencial e sincrético que ele propõe. $\mathrm{O}$ conflito local-global estará presente, assim como as contextualizações históricas, mas sempre em prol da anarquia das digressões e intuições antropofágicas.

O pensamento de Oswald apresenta a oposição entre a "cultura da escravidão" e a "cultura da liberdade" em diversos contextos, e não apenas no brasileiro e latino-americano. Com a mesma autoridade, comenta sobre a Grécia antiga, o feudalismo, a renascença ou a colonização, sem, necessariamente, acrescentar justificativas localistas para cada ideia que concebe. Comenta de Sócrates a Lutero sem os recibos bibliográficos tão caros aos "cidadãos letrados" de todos os tempos. Enfim, para a antropofagia o que importa não é provar a verdade, mas provocar a verdade.

\footnotetext{
${ }^{15}$ BERNABÉ, 2007.
} 


\section{2 \\ O primitivismo segundo a genealogia e a dialética
antropofágicas}

2.1.

O ensaísmo antropofágico

Desde que os cronistas do século XVI se depararam com a antropofagia na América, os ocidentais tentam decifrá-la ${ }^{16}$. Historiadores e antropólogos buscaram explicar as distintas razões de ser da cerimônia nos povos mais "civilizados" (Astecas, Maias e Incas) e nos mais "primitivos" do continente. Escritores como Montaigne, Skakespeare, Machado de Assis, Freud e Paul Valéry contemplaram por diferentes ângulos seus desdobramentos simbólicos.

Após a Primeira Guerra Mundial, as vanguardas europeias retornaram ao tema com frequência. Na maioria das vezes, o assunto foi explorado na forma de crítica à barbárie trazida pelo progresso tecnológico ou como metáfora para a "digestão" do conhecimento e da experiência artística. Benedito Nunes e Heitor Martins ${ }^{17}$ lembram que Appollinaire, Cendrars, Cocteau, Marinetti, entre outros, sondaram o assunto. Em 1920, Francis Picabia publicou o Manifesto Canibal Dadá, seguido da revista Cannibale.

Como se pode ver, apesar da originalidade de Oswald de Andrade, o imaginário que ronda a temática do canibalismo tem uma longa e variada história, da qual se deduz que não existe uma, mas muitas antropofagias.

Se, além disso, lembrarmos que a versão modernista brasileira reuniu vários escritores, que se vinculou às artes plásticas, e que, quarenta anos depois,

\footnotetext{
${ }^{16}$ Para ser preciso, existem referências à antropofagia em Homero, Ésquilo, Heródoto e Plínio. Como nos informa Carlos Jaugueri, até a Idade Média, tratados medievais como Etimologias de Isodoro de Sevilla e

Imago mundi de Pierre d'Allys em capítulos sobre monstros, além de relatos de viagens como The travels of sir Jonh Mandeville comentaram sobre a antropofagia. Não se pode precisar, contudo, em que grau tais relatos mitológicos tinham qualquer contato com a realidade. (JAUGUERI, 2008, p.50).

${ }^{17}$ MARTINS, 1973; NUNES, 1979.
} 
reapareceu metabolizada pelo teatro, cinema e música, chegamos à conclusão de que não existe, sequer, uma antropofagia brasileira única.

No Brasil, as incontáveis expressões estéticas e teóricas impulsionadas pela antropofagia fizeram dela uma espécie de convite à ressignificação. Embora essas reinvenções tenham dialogado com as questões culturais específicas de cada contexto, não se pode negar que a trajetória da antropofagia foi heterogênea, guiada por roteiros variados e em diferentes meios. Mais do que isso, não se pode afirmar que qualquer uma dessas manifestações seja a definição acabada da ideia.

Não há regras que permitam identificar, por exemplo, qual obra é a mais antropofágica entre Serafim ponte grande, de Oswald, Cobra Norato, de Raul Bopp ou a Idade da terra de Glauber Rocha. É claro que, se alguém disser que As Bodas de Fígaro de Mozart é tão antropofágica quanto um Parangolé de Hélio Oiticica, corre o risco de tornar o conceito irrelevante. Apesar disso, talvez esteja mais atento à riqueza da noção do que os que buscam mandamentos no Manifesto Antropófago.

$\mathrm{Na}$ verdade, o próprio Oswald não seguiu o Manifesto religiosamente. De 1944 em diante, ampliou de modo significativo suas intuições modernistas em vários ensaios. As mudanças que engendrou na antropofagia, porém, não a aproximaram de sua verdade essencial. Surgiram variações estratégicas, ampliações temáticas, desvios de rota, mas, com isso, não se pode dizer que a antropofagia ensaística seja mais antropofágica do que a modernista, ou viceversa.

A ausência de um eixo central de significação não deve, todavia, ser entendida como sinal da gratuidade de sentidos. Não é a escassez de representações e usos precisos que dificulta a designação fechada da antropofagia, mas o exato oposto, ou seja, a profusão de expressões pertinentes ao termo.

Por esse motivo, longe da presunção de encerrar um assunto tão vasto, o que pretendo neste capítulo é apenas fornecer elementos para a leitura crítica dos ensaios antropofágicos. Neles, Oswald trabalha sobre um corpo de autores, tópicos e argumentos que transitam circularmente, dialogando a serviço de algumas hipóteses cardinais. Apesar da metodologia caótica, percebe-se nos textos o esforço para a teorização de uma "filosofia antropofágica". Minha ideia é 
aparar arestas para nos próximos capítulos, ao entrarmos de vez nessa "filosofia", termos à mão ferramentas para acessar suas heterodoxas reflexões.

Devemos começar reparando que, como é típico do gênero, nos ensaios antropofágicos não existe preocupação sistemática com a formulação dos conceitos. Oswald simplesmente lança as ideias ou, na melhor das hipóteses, fornece algumas linhas de definição. Os conceitos ganham clareza ao longo dos textos, nas relações que estabelecem entre si.

Todos sabemos o que é um ensaio. Descrevê-lo, contudo, não é tarefa simples. O termo sugere um experimento. Mais precisamente, uma experiência literária de livre reflexão. $\mathrm{O}$ ensaio é literatura, mas não é romance ${ }^{18}$. Pode versar sobre qualquer assunto, mas o mais comum é vê-lo orbitando em torno de questões filosóficas, psicológicas e de história da arte e da cultura (costumes, moral, ideias, etc.), com o auxílio de metáforas e intuições.

Do ângulo epistêmico, os ensaios são transgressões das teorias do conhecimento porque misturam seus limites, ignoram suas prerrogativas e desqualificam a objetividade. Afora isso, contaminam as metodologias por não reduzirem o objeto em questão a um significado exaustivo, manipulando-o livremente até perdê-lo de vista. O ensaio não tem o norte dos ideais de clareza e distância. Sua técnica é idiossincrática.

Para o crítico argentino Ricardo Forster, os ensaios são "artesanatos da suspeita". Se por um lado suas origens remontam aos primeiros passos do "espírito moderno" e da filosofia do sujeito, por outro, sua linguagem provisória sempre fez resistência às tentativas de transparência da razão. Segundo Foster: "El ensayo há sido la escritura de la sombra, el revés de la luz racional, la fisura en el muro de la certeza cartesiana, la poética de la hegeliana 'noche del mundo" " (Foster, 2011, p.16).

Em $O$ ensaio como forma, Adorno introduz o problema por um caminho similar, avocando o processo de des-mitologização da civilização ocidental que separou a arte da ciência. Para ele, essa objetivação do mundo era incontornável.

18 Todavia, é importante comentar que assim como os romances podem adquirir feições ensaísticas, os ensaios também podem adquirir aspectos romanescos. Com Oswald isso é bastante comum, principalmente quando envereda pelas descrições históricas e diálogos imaginários. Desenvolvo esse debate no capítulo 4. 
Não há como retomar a unidade entre intuição e conceito com o passe de mágica da linguagem literária, como pretendiam alguns ensaístas. Com esses escritores, o mais comum era que essencialismos, falsas datas e outros clichês filosóficos, ao invés de serem criticados, fossem implicitamente endossados. Terminavam por "misturar o rebotalho da psicologia interpretativa com categorias banais derivadas da visão de mundo do filisteu da cultura, tais como a 'personalidade' e 'o irracional'(...) Ensaios ruins não são menos conformistas do que dissertações ruins" (Adorno, 2003, p.17), afirmava o escritor.

Até aí, a crítica de Adorno parece ter sido feita de encomenda contra a “filosofia antropofágica”. Não só porque Oswald incorre com certa regularidade em essencialismos filosóficos e clichês psicologistas, mas principalmente porque, para ele, retomar a unidade entre razão e mito, jogo e ciência, não era uma questão de capricho estilístico, mas uma das suas fundamentais diretrizes ideológicas.

$\mathrm{Na}$ sequência do texto, entretanto, Adorno começa a defender o ensaio enquanto forma. Isto é, para além dos ensaístas. Nesse caso, pondera ele, ainda que a separação entre arte e ciência fosse irreversível, não deveríamos "hipostasiar o antagonismo". Ele pensava que setorizar completamente filosofia, ciência e arte era o mesmo que acreditar que "todo conhecimento pode ser convertido em ciência". (Adorno, 2003, p.18).

Não obstante, diz Adorno, há uma diferença qualitativa entre a consciência viva e a consciência científica. Das reflexões mais banais até as grandes obras de arte existe um universo de conhecimentos ligados à vida não categorizáveis pela ciência (ou pela filosofia, poderíamos acrescentar). ${ }^{19}$

Como discurso, o ensaio se diferencia da ciência e da filosofia por não priorizar o "fato concreto" ou a "teoria" sobre a "cultura", que, de resto, não é necessariamente vista como uma obstrução para a Verdade, para a Razão ou para o Ser. No ensaio, os objetos em pauta não são abordados em função de sua

\footnotetext{
${ }^{19}$ Um exemplo da argumentação de Adorno: "A obra de Marcel Proust, tão permeada de elementos científicos positivistas quanto a de Bergson, é uma tentativa única de expressar conhecimentos necessários e conclusivos sobre os homens e as relações sociais, conhecimentos que não poderiam sem mais nem menos ser acolhidos pela ciência, embora sua pretensão à objetividade não seja diminuída nem reduzida a uma vaga plausibilidade. O parâmetro da objetividade desses conhecimentos não é a verificação de teses já comprovadas por sucessivos testes, mas a experiência humana individual, que se mantém coesa na esperança e na desilusão. Essa experiência confere relevo às observações proustianas, confirmando-as ou refutando-as pela rememoração" (ADORNO, 2003, p.18).
} 
cognoscibilidade. Em geral, as condições de possibilidade de conhecimento não são problematizadas, ou, ao menos, não são priorizadas como o ponto ao qual toda a argumentação deve pagar tributo.

Para Adorno, o fato de os ensaios terem sido relegados à segunda categoria do pensamento, tem a ver com a "alergia contra as formas" que tanto aproximou o academicismo do dogmatismo. Ele lamenta que esta velha imposição platônica do intemporal sobre o acidental e da totalidade sobre o fragmento tenha conseguido com que "a reflexão sobre as coisas do espírito se tornasse privilégio dos desprovidos de espírito" (Adorno, 2003, p.18).

No caminho oposto, o ensaio desde suas origens se construiu sobre a consciência da não-identidade. Sua inclinação cética sempre pôs em dúvida os direitos incondicionais do método, mas sem apologias contrárias. Simplesmente se abstendo "de qualquer redução a um princípio e acentuando, em seu caráter fragmentário, o parcial diante do total" (Adorno, 2003, p.19). Fraturando a ortodoxia do pensamento, o ensaio pretendeu deixar à vista aquilo que o monopólio cientificista e filosófico do saber quis manter invisível.

Ao fim do texto, Adorno faz outro comentário que cai feito uma luva sobre a antropofagia ensaística. Desta vez, contudo, a favor dela:

\footnotetext{
O ensaio devora as teorias que lhe são próximas; sua tendência é sempre a de liquidar a opinião, incluindo aquela que ele toma como ponto de partida. $\mathrm{O}$ ensaio continua sendo o que foi desde o início, a forma crítica par excellence. Mais precisamente, enquanto crítica imanente de configurações espirituais e confrontação daquilo que elas são com o seu conceito, o ensaio é crítica da ideologia. (Adorno, 2003, p. 26).
}

Uma das hipóteses dessa tese é a de que a "filosofia antropofágica" é uma crítica ideológica em dois sentidos. De uma forma explícita, ela é uma crítica às ideologias identificadas como "patriarcais". De modo mais sutil, um estudo dos processos de formação ideológica. Melhor dizendo, uma análise ensaística sobre as relações entre poder e imaginário ao longo da história. 
Em relação a este último aspecto, além da tradição ensaística, a antropofagia filosófica também tem raízes na crítica de Nietzsche e $\operatorname{Marx}^{20}$ à filosofia da história iluminista. Como observou Haiden White, os dois autores, seguindo o caminho asfaltado por Hegel, forjaram uma compreensão da história para além do racionalismo secular. De formas diferentes, ambos enfrentaram a ideia de um alicerce racional transcendental precedendo e explicando as relações empíricas.

(...) Para nenhum dos dois havia qualquer coisa que se assemelhasse a um fundamento axiologicamente inócuo, sobre o qual se pudesse objetivamente justificar a escolha entre diversas estratégias de explicação e elaboração de enredo. Em consequência de tudo isso veio à tona a questão do que se entende por objetividade (...). Foi a natureza da própria objetividade que eles puseram em questão (White, 1992, p.287)

É verdade que o Romantismo, desde seus prelúdios no século XVIII, já questionava a noção de objetividade, se opondo radicalmente ao isolamento da imaginação fora do terreno histórico. Com isso, os românticos retomavam o que autores como Erasmo, Montaigne e Vico tinham iniciado nos séculos XVI e XVII, ao lançarem o dilema das bases irracionais da racionalidade, e do papel dessas estruturas na construção de instituições sociais e culturais as mais variadas.

Da metade século XIX em diante, entretanto, a diluição da fronteira entre razão e imaginação foi radicalizada. Nesse ponto, Nietzsche e Marx foram além do subjetivismo romântico e do mecanicismo iluminista e se perguntaram sobre as motivações encobertas pelas definições "objetivas" e "subjetivas" da suposta "verdade".

\footnotetext{
${ }^{20}$ Quando aponto a presença de Marx nos ensaios, deve-se considerá-la de forma mais genérica do que a de Nietzsche. Pode-se imaginar a massiva literatura de comentaristas marxistas que Oswald e os intelectuais da década de 1940-50 estavam expostos, e como isso tudo se misturou na linguagem coeva e, consequentemente, nos ensaios. A princípio, portanto, não farei distinção entre Marx e marxismo em geral. Ao invés disso, adoto como parâmetro os aspectos gerais das diretrizes filosóficas marxistas, que correspondem ao que Henry Lefebvre comenta na seguinte passagem: "Considerado filosoficamente, o marxismo nos apresenta dois aspectos principais. O primeiro é o aspecto metodológico. Hegel havia retomado e desenvolvido em sua Lógica algumas questões já tratadas - por Aristóteles, Descartes, Leibniz e Kant -, relativas ao emprego metódico da Razão. Marx, no decorrer de seus trabalhos científicos, aprofundou a lógica hegeliana e continuou a elaboração do método dialético. Por outro lado, Hegel em sua Fenomenologia do espírito, esboçou uma história geral da Consciência Humana. Marx retomou esse esforço; da fenomenologia, ele reteve principalmente, com o propósito de transformá-la em teoria concreta, a célebre e obscura noção de alienação." (LEFVBRE, 2011, p.26)
} 
O que ambos tiveram em comum foi sublinhar a luta de poder por trás das descrições da realidade, demonstrando os interesses velados das teorias históricas, filosóficas e científicas em voga. Os dois escritores (e logo em seguida, Freud) revelaram o lado sombrio e obsceno da civilização, expondo o que havia de precário, violento, repressivo e bárbaro sob o nobre discurso do progresso.

Por reconhecerem a contiguidade entre razão e imaginação, tanto Marx quanto Nietzsche formularam "o problema histórico como um problema de consciência e não simplesmente de metodologia" (White, 1992, p.287). Para os dois, pensar sobre o passado implicava interesse direto na forma de lidar com o presente. $\mathrm{O}$ conhecimento histórico deveria estar em sintonia com a transformação da vida, mais do que com a inerte reconstituição do passado.

A maneira como articularam essa percepção, no entanto, diverge em inúmeros pontos inconciliáveis. Entre eles, Marx desenvolveu as noções hegelianas de dialética e de alienação, transportando-as para os terrenos presumidamente científicos da história, da sociologia e da economia, com a finalidade da intervenção política. Nietzsche, pelo contrário, negou categoricamente a dialética desde suas raízes socráticas até Hegel. Em seu lugar propôs uma transvaloração dos valores platônico-cristãos e modernos (incluindo a reverência pela ciência e pela razão). Para isso, elaborou uma interpretação psicológica do poder, direcionada para os meandros do discurso moral e destinada ao cultivo de si.

Pretendo demonstrar que a versão oswaldiana da história da civilização promove uma tensão entre o olhar psicológico de Nietzsche e a mirada sociológica de Marx. Como eles, Oswald também interpreta a história como a história das lutas de poder. Nos ensaios elas são retratadas como expressões do embate entre duas inclinações psicossociais do ser humano (o matriarcado e o patriarcado), em análises que oscilam entre "genealógicas" e "dialéticas".

Isso não significa que a antropofagia ensaística seja o mero resultado da influência de Marx e Nietzsche. Tal afirmação seria primária, além de grosseiramente imprecisa. Com perdão do clichê, os dois autores são "antropofagizados" por Oswald. Embora seus nomes sejam fartamente citados (muitas vezes em desaprovação), suas ideias estão longe de ser metodicamente 
delineadas e sofrem todo tipo de reelaboração. Vem daí o meu interesse por investigá-las. Meu propósito é o de refletir sobre o uso que Oswald faz dos dois autores.

Ademais, ainda que Nietzsche e Marx sejam seguramente os escritores mais presentes, não se pode dizer que são predominantes nos ensaios. Nada é "predominante" na obra de Oswald. Toda ela é babélica e imprevisível, como, aliás, foi o próprio Oswald.

Feita a ressalva, o que sugiro é que Marx e Nietzsche funcionam como duas temperaturas distintas do mesmo termômetro das especulações antropofágicas acerca das origens e do destino da civilização. Para esclarecer a hipótese é importante primeiro uma palavra sobre Montaigne.

\section{2. \\ 0 índio abstrato}

Existe um certo consenso de que o gênero ensaístico começa com Montaigne. Entre referências da história e da filosofia Antiga, seus Essais meditam sobre temas clássicos da vida a sós e em sociedade. As reflexões, quase sempre, concluem afirmando a inconstância de nossos julgamentos e a fragilidade das convenções e crenças aceitas.

André Gide observou que "Montaigne não nos traz nenhum método, nenhum sistema filosófico ou social. Nada menos ordenado que seu pensamento; deixa-o brincar ao acaso, vagabundear ao léu." (Gide, 1975, p.14). Tudo isso lhe rendeu as interpretações mais variadas. Pascal e Kant enxergaram um cristão; Emerson, o maior dos céticos; Sainte-Beuve, uma preparação da Ética de Espinosa, e assim por diante.

No que toca à antropofagia, é bastante comentada a importância do ensaio Des canibales para a gestação do Manifesto em 1928. Em geral, dois tópicos clássicos da antropofagia são analisados à luz do texto de Montaigne. Uns ressaltam sua crítica ao etnocentrismo europeu e, consequentemente, seu precoce 
"relativismo cultural"; outros se atêm ao debate da subversão do sujeito racional quando defrontado com a lógica antropofágica de apropriação da alteridade.

No entanto, como expliquei na introdução, minha ideia é chamar a atenção para outros pontos menos comentados, em consonância com os ensaios de 194454. Em vista disso, pode-se dizer que a passagem do tempo não diminuiu a admiração de Oswald por Montaigne, a quem, nos momentos mais entusiasmados, chegou a atribuir "o sentido do ciclo humanista-renascentista". Dizia que o capítulo dos canibais expressava "não só o primeiro grito de revolta que se proferiu no Ocidente contra a diferença de classes, mas também a crítica contra o princípio dinástico que envenenava reinos e povos de toda Europa." (OA, 1991, p. 255).

Como se sabe, o famoso ensaio relativiza as ideias de bárbaro e civilizado. Entre comentários que vão da "vitória de Pirro" sobre os (então bárbaros) romanos até um inusitado diálogo entre o próprio autor e um índio brasileiro em Rouen $^{21}$, Montaigne destaca aspectos elevados das sociedades primitivas como, por exemplo, sua moralidade "que resume-se em dois pontos: valentia na guerra e afeição por suas mulheres” (Montaigne, 2000, p. 198).

Quanto ao ritual antropofágico, busca entender seus significados interpretando-os como consequência do modo nobre e generoso com que faziam a guerra. Conclui dizendo que "Podemos qualificar esses povos como bárbaros tendo em vista as regras da razão, mas não tendo em vista a nós mesmos, que os superamos em toda espécie de barbárie". (Montaigne, 2000, p.199).

Antonio Cicero traz uma interpretação relevante para a frase. Ele diz que Montaigne "fala de um ponto de vista que é não só exterior ao da cultura dos índios, mas exterior também ao da cultura cristã em que fora criado: por isso ele é capaz de criticar essa cultura. E esse ponto de vista é, segundo Montaigne, o das 'regras da razão', ou, simplesmente, o da razão” (Cicero, 2012).

\footnotetext{
${ }^{21}$ Como curiosidade, reproduzo a versão de Oswald para o diálogo, que ganha a seguinte cara: "O fato histórico que provocou o capitulo "Des Canibales" foi a ida de um grupo de índios brasileiros à corte de Rouen, em 1557(?). Narra Montaigne que interrogado sobre se admirara o luxo e conforto dos palácios de Rouen um índio brasileiro havia respondido. "Muito. Mas o que mais me admira é que o povo que vive na lama e no frio não queime esses palácios". Em seguida vendo a figura de Carlos IX, que sentado no trono tinha ao seu lado, de pé, um magnífico guarda suíço, um outro índio teria perguntado por que não se retirava do trono aquele tipo enfermo e ridículo de rei para sentar-se nele o suíço esplendido e feroz.” (OA, 1991, p.255)
} 
Para Cicero, o que o ensaísta francês antecipava era, mais do que o relativismo cultural, a condição desse relativismo, isto é, a afirmação de uma concepção universal aberta a qualquer ser humano independente da cultura a que pertence: "O ponto de vista da razão, do iluminismo, da modernidade." (Cicero, 2012).

Por estranho que possa parecer a alguns, tal análise não está tão distante do pensamento da antropofagia tardia. Acontece que o Oswald dos ensaios não converge plenamente para as correntes contemporâneas que entendem o universalismo da razão iluminista como um etnocentrismo europeu disfarçado. Ao contrário, ele é admirador da razão crítica, isto é, da razão negativa, aquela que critica a si mesma, diferentemente dos conhecimentos positivos. Esta seria, segundo Cicero, a condição para toda crítica que se pretenda fora dos costumes particulares.

Isso não quer dizer que Oswald não tenha reservas aos abusos de poder que foram feitos em nome da razão (o que marxistamente chamará de "razão de classe"). No entanto, sua crítica à civilização ocidental se prende ao abrangente conceito do patriarcado messiânico. Contra este, a razão moderna desferiu alguns de seus maiores golpes e Oswald reconhece isso. A citação abaixo é longa, mas vale a pena para compreendermos as facetas menos divulgadas de seu pensamento:

O fato de Descartes ter enunciado como chave de seu enigma aquele admirável "j'avance masqué" basta para fazer compreender os recuos e balanços com que ele se furtou à temibilidade do braço secular. A obra de Descartes foi além de suas conquistas matemáticas, pois teve mérito de pôr fim às torvas cogitações do tomismo medievo que pretendia trazer ainda a Escolástica aos debates do mundo moderno.

Algumas frases apenas, colhidas na obra do filósofo francês, são a pedra de toque dessa reviravolta que ele ocasionou nos caminhos confusos que a pedralha erudita pretendia indicar à cultura e à civilização. $\mathrm{O}$ importante foi René Descartes ter criado contra um mundo de aberrações místicas e de esclerose espiritual, o racionalismo. Do seu método, das suas ideias claras e distintas, vem uma linha reta que daria em nossos dias o poder persuasivo de Lênin. Aliás, é deste a seguinte expressão: "É preciso fazer penetrar no cérebro do proletário ideias claras e simples como pregos".

Descartes foi, na metodologia intelectual e pedagógica, o criador do prego, isto é, da ideia irrefutável. O que representa no século XVII a vida e a obra de René Descartes é um monumento de sabedoria, de bom senso e de cultura, em face do pesadelo pascaliano e da escusa briga entre jansenistas e jesuítas que encheu de 
um inútil clamor toda essa época. Descartes conquistou para si a laura de primeiro pensador moderno da Europa, na era da razão e do seu predomínio longe das tricas com Deus, com a revelação e com os padres.

Se, desviada pelos interesses políticos da burguesia ascendente, essa razão se tornou uma razão de classe, nada infirma ou nega ela ter sido o ponto inicial dos progressos intelectuais e científicos da modernidade (OA, 1991, p.258-259).

Apesar do flerte com o racionalismo, seria absurdo dizer que Oswald era um racionalista ${ }^{22}$. Na verdade, interessava-lhe muito mais os escritores do século anterior (XVI), fossem eles utopistas como Morus e Campanella ou céticos como Erasmo e, de certa forma, o próprio Montaigne. Este, inclusive, ao fim de toda a racional e amistosa reflexão sobre os canibais, termina o ensaio com o mordaz comentário: "Tudo isso é, em verdade, interessante, mas, que diabo, essa gente não usa calças!" (Montaigne, 2000, p.203). Ora, essa quebra de expectativa, essa ironia desconcertante, é a marca não do racionalismo, mas do profundo "ceticismo" dos Essais. ${ }^{23}$

Logo após a aula de universalismo esclarecido, Montaigne descarta sutilmente a possibilidade de não ser etnocêntrico. Pela liberdade com que afirma juízos opostos, o autor termina oferecendo um retrato da sua própria consciência em movimento, mudando de opinião, instável. Esse tipo de construção se repete em quase todos os seus textos, e é um dos motivos pelo qual Montaigne é considerado como o "pai" dos ensaios.

A natural oscilação dos indivíduos é seu álibi para defender a impossibilidade de uma moral de validade objetiva. Nas palavras de Montaigne, "O bem e o mal só o são, as mais das vezes, pela ideia que deles temos" (Montaigne, 2000, p.66). De seu "ceticismo", no entanto, não resulta a indiferença, mas o mergulho em si próprio e a busca de um ponto de equilíbrio e

\footnotetext{
${ }^{22}$ Até porque em vários momentos a antropofagia pode ser abertamente paradoxal, etnocêntrica, romântica e ufanista.

${ }^{23}$ Claro que, no que se refere à história da filosofia, o ceticismo de Montaigne pode ser entendido como uma prévia do racionalismo por vir. Montaigne "deixou aberta a possibilidade de se concluir que a própria contradição pudesse ser verdadeira. Em certa medida foi o que viria a acontecer com Descartes: a suspensão pirrônica de juízo, encontrada no autor dos Ensaios, transformou-se na dúvida metódica cartesiana e a análise do Eu possibilitou a Descartes concluir "penso, logo existo". (CHAUÍ, 2000, p. 19-20).
} 
quietude interior. Essa postura foi entendida por alguns como uma atitude "estoica"24. Explica Marilena Chauí:

O ceticismo resguardaria o indivíduo contra o império das normas morais impostas pelos outros e, opondo-se a todas as convenções arbitrárias, assegurarlhe-ia a liberdade. Ligam-se as teses fundamentais da filosofia cética e os temas centrais do estoicismo ético, o que levou muitos intérpretes a rotular Montaigne como um estoico (...). Contudo, nem a lógica nem a metafísica do estoicismo grego encontram-se presentes em Montaigne. Assim ele só pode ser enquadrado como estoico na medida em que afirma claramente a autonomia moral do indivíduo, diante dos costumes e das convenções arbitrárias (Chauí, 2000, p.16).

Oswald não pode ser considerado um intérprete de Montaigne. Mas sua interpretação do Des Canibales o levou à conclusão de que o ensaísta francês descrevia uma postura "estoica" do índio perante a hierarquização social de Rouen. É possível que tenha sido estimulado por uma breve passagem do texto, na qual Montaigne, defendendo a antropofagia, afirma que Crisipo e Zenão (chefes da escola estoica) não viam problema em alguém se alimentar de cadáveres numa situação de necessidade. Seja como for, para Oswald: "O Ocidente nos mandou com o messianismo todas as ilusões que escravizam. Montaigne, no seu grande capítulo dos Essais, onde exalta 'Les Canibales', foi o primeiro que viu o caminho novo, o dado pela revolta e pelo estoicismo do índio.” (DD, 1990, p.230).

Sobre o estoico, Pierre Hadot explica que, embora tivesse como parâmetro de ação a Razão cósmica manifesta na natureza, sua complexa visão moral, muitas vezes, não descartava a "recusa ao destino, o revoltar-se contra a ordem universal e agir ou pensar contra a Razão universal e a natureza" (Hadot, 1999, p.193). Como Sócrates, exigiam o bem para além do interesse individual. Diferentemente de Platão pretendiam que o bem moral fosse acessível a todos neste mundo. Segundo Hadot: 'O estoico age sempre 'sob reserva', mas age, toma parte na vida social e política" (Hadot, 1999, p. 198).

\footnotetext{
${ }^{24}$ Os termos ceticismo e estoicismo aparecem entre aspas para ressaltar que estamos lidando com um sentido latu sensu das escolas helenistas, tal como são guiados pelas discussões nos ensaios oswaldianos. Naturalmente, se empreendermos uma avaliação rigorosa para as definições de estoicismo e ceticismo, encontraremos inúmeras inconsistências no uso disposto na antropofagia. Não é nosso objetivo, porém, conferir a rigorosidade da terminologia oswaldiana, mas esclarecê-la nos seus próprios termos ensaísticos.
} 
Será que Oswald estava atento a esse sutil balanço entre aceitação do destino e liberdade de escolha (esse fatalismo "com reservas") ao equiparar a postura do estoico à do primitivo?

Em outro famoso ensaio intitulado De como filosofar é apreender a morrer, Montaigne defende que "meditar sobre a morte é meditar sobre a liberdade; quem aprendeu a morrer, desaprendeu a servir; saber morrer nos exime de toda sujeição e constrangimento" (Montaigne, 2000, p.97). Oswald segue lógica semelhante para definir a autonomia do primitivo:

Ao nosso indígena não falta sequer uma alta concepção da vida para se opor às filosofias vigentes que o encontraram e o procuraram submeter. Tenho a impressão de que isso que os cristãos descobridores apontaram como o máximo de horror e a máxima depravação, quero falar da antropofagia, não passava entretanto de um alto rito que trazia em si uma Weltanschauung, ou seja, uma concepção da vida e do mundo.

$\mathrm{O}$ indígena não comia carne humana nem por fome nem por gula. Tratava-se de uma espécie de comunhão do valor que tinha em si a importância de uma posição filosófica.

A Antropofagia fazia lembrar que a vida é devoração opondo-se a todas as ilusões salvacionistas.

Foi Montaigne que, num de seus Essais, tratando dos canibais me chamou a atenção para a importância autônoma do primitivo. (RP, 1991, p.231)

É difícil determinar até que ponto o "estoicismo" que Oswald enxergava no primitivo tem algum embasamento ou é completamente distorcido. Às vezes, mais parece um carnaval helenista, pois, em menor escala, os índios também são retratados como "epicuristas" e "céticos". Talvez o mais indicado seja interpretar os termos em cada circunstância, de acordo com a argumentação, pois não existe uma continuidade de valor rigidamente atrelada aos seus usos. Oswald não fica encabulado de elevar uma coisa (fato, ideia, personagem, escola) em um contexto e reprovar em outro. A prova disso é que, quando vai comentar o Elogio da loucura, endossa com prazer as críticas de Erasmo aos estoicos ${ }^{25}$.

\footnotetext{
${ }^{25}$ “O Estoicismo, com seu culto à virtude torna-se a sua bêtenoire: 'Que vão passar a vida na cidade de Platão! - exclama para os estóicos que acusa de insensíveis e surdos à voz dos sentidos' (MU, 1970, p.167)
} 
De qualquer forma, podemos afirmar com tranquilidade que as inconsistências agem a serviço de certas coerências de fundo. Do contrário tudo se perderia em puro caos. No caso em questão, creio que o que importava para Oswald não era provar que os índios pensavam ou agiam como os estoicos, mas fornecer elementos para a imaginação de uma subjetividade contrária às derivadas da crença messiânica na salvação individual. Estimular novas concepções de sujeitos e sociedades era um recurso tão frequente quanto desmascarar falsidades ideológicas. Nos ensaios, os dois trabalhos são complementares. Os problemas se colocam não apenas na esfera do que fomos ou somos, mas também na do que gostaríamos de ser.

Por isso, o índio do qual fala Oswald obviamente não existe. Ele é uma abstração. Uma figura retórica que serve de contraponto para outra abstração: o individuo histórico e civilizado, fruto do patriarcado.

Gonzalo Aguillar define com rara precisão e criatividade essa manobra conceitual de Oswald:

El indio fue una suerte de pequeño objeto $a$, objeto deseado y sustraído que a Oswald le permitió ver ciertos mecanismos de la cultura brasileña. El indio fue el don, fue aquel que, a través de la lectura de textos de la época del descubrimiento y de otras fuentes, le obsequió a Oswald las grandes hipótesis (la antropofagia, el matriarcado, la crisis de la filosofía mesiánica) con las que recopiló y enlazó los indicios que lo deslumbraban en la vida cotidiana.

Oswald empleó al indio (a la figura del indio) para hacer la crítica del Estado, la sociedad patriarcal, el moralismo, la Estética y las creencias. La separación fundamental de Oswald en relación con el romanticismo no está tanto en el cambio de signo de la valoración del indio (del buen salvaje al mal salvaje) sino en que separa al indio del Estado. En realidad, más que separarlo lo opone: el indio surge como la garantía antiestatal de la política (...) (Aguillar, 2010, p.7).

Aguillar lembra en passant que, o que era uma especulação estratégica em Oswald, mais tarde, ganhou dados de concretude nas observações de Pierre Clastres e em sua concepção de sociedade contra o estado. Para o antropólogo francês, a ausência de um órgão de poder separado (Estado) nas sociedades primitivas não era consequência de seu presumido estágio inicial de civilização, mas do fato de que suas instituições se organizavam contra a formação do Estado. 
Dito de outro modo, não é que os primitivos não se colocassem a questão do poder, mas que sua política constituía-se de um único projeto: "manter na indivisão o ser da sociedade." ${ }^{26}$ (Clastres, 1982, p.110).

A confluência com Clastres, todavia, deve ser tomada com cautela. A credibilidade das noções oswaldianas de primitivo e matriarcado depende da premissa de que ele não faz antropologia, mas literatura ensaística. Pela literatura, é claro, Oswald desenvolve uma crítica aos valores, convenções e instituições reais. As situações que descreve, porém, não são necessariamente reais.

Diferentemente de Clastres, em Oswald, o primitivismo não é concreto. É um conceito fluido, que pode se referir tanto à visão de mundo do índio colonial quanto aos impulsos latentes do cidadão moderno. Pode ser o signo da revolta estoica contra o poder ou da adesão das massas à Hitler e Mussolini.

Dizer que o índio da antropofagia não é real, mas "imaginário" ou "abstrato", não significa dizer que não deva ser levado a sério. Pelo contrário, uma das propostas da filosofia antropofágica é esmiuçar o ambivalente papel da imaginação como crítica e adesão às ideologias ligadas à nossa realidade.

Guardadas as diferenças, não há dúvidas de que, como Clastres, Oswald parte de uma concepção de "primitivo" para se colocar questões acerca do Estado (que para ambos é sinônimo de civilização e historia). Perguntas como "O que é o poder político, isto é, a sociedade? Como e porque se passa do poder político nãocoercitivo ao poder político coercitivo? Isto é: o que é a história?" (Clastres, 1982b, p.19). No caso específico da antropofagia ensaística, acrescentaríamos à lista outra pergunta indispensável: como contar a história da não coerção se a própria história é a história do poder? Quer dizer, como contar a história dos submetidos?

O desejo de rasurar a oposição entre primitivo e civilizado é um dos notórios motores da antropofagia. É desse horizonte que Oswald observa as dimensões ocultadas da história. A crença no trânsito entre as duas instâncias é,

\footnotetext{
${ }^{26}$ Conclui Clastres: "Segue-se que este poder se exerce sobre a instituição da qual poderia surgir a captação do poder, a chefia. O chefe em sua tribo está sob vigilância. A sociedade cuida para não deixar o gosto do prestígio transformar-se em desejo do poder. Se o desejo de poder do chefe tornar-se por demais evidente o procedimento é simples: ele é abandonado e até mesmo morto. $\mathrm{O}$ espectro da divisão talvez atormente a sociedade primitiva, mas ela possui meios de exorcizá-lo." (CLASTRES, 1982, p. 110). Seria a antropofagia um desses meios?
} 
também, o que lhe impulsiona a deslizar sobre os tradicionais dualismos do pensamento ocidental.

Organizados sobre essa estrutura movediça, é de se esperar que os ensaios sejam fracionados e intempestivos. Se, todavia, quiséssemos definir alguma unidade nas reflexões de Oswald, um dos poucos caminhos viáveis seria dizer, como Aguillar, que todo seu pensamento é uma rebelião contra o autoritarismo no saber e na vida. O problema é que, mal chegamos a esta síntese, temos que admitir que a revolta não é livre de contradições. Principalmente por que nela convivem: "una concepción lúdica, humorística y agonística de la vida con otra dialéctica, teleológica y transcendente" (Aguillar, 2010, p.5). Concordo com o crítico argentino e penso que esta é uma maneira de descrever a presença simultânea de Nietzsche e Marx nas cogitações oswaldianas.

Em contato com o marxismo, Oswald abre a lente para o cenário panorâmico, apontando para os ciclos dialéticos da "luta de classes" entre o matriarcado e o patriarcado ao longo da história. Aqui nos deparamos com a utopia antropofágica profetizando um novo período coletivista, que pelo desenvolvimento da técnica eliminaria a necessidade do Estado. O conceito de primitivo nessas horas se orienta pelo sentido comunitário.

Instigado por Nietzsche, os ensaios se cobrem de perguntas sobre o valor dos valores em questão. É a vez do Oswald iconoclasta que confronta a ação sacerdotal sobre as esperanças e temores dos homens, principalmente em três modalidades messiânicas ocidentais: a socrática, a católica e a protestante. Pelo filtro nietzscheano, o primitivo ganha acepção trágica, refletido na resignação à devoração cósmica, e no anseio de livre expressão lúdica e sexual.

Em ambos os casos, o código primitivo ${ }^{27}$ é obliterado pelas instituições patriarcais. Por meio do que poderíamos chamar de uma "genealogia antropofágica", Oswald interpreta suas expressões libertárias, ao passo que por uma "dialética antropofágica" decifra sua demanda por justiça comunitária. Como veremos, a intercessão entre as duas perspectivas nem sempre é harmônica.

\footnotetext{
${ }^{27}$ No próximo capítulo veremos as demais nuances do conceito de primitivo em seus sucedâneos, o "orfismo", o "homem natural" e o "matriacado".
} 


\section{3. \\ Genealogia antropofágica}

Passo a uma rápida definição do que estamos chamando de genealogia. Uma das marcas registradas da obra de Nietzsche é sua guerra particular contra as noções de origem metafísica do significado e de linguagem como representação. Para ele a origem do significado das coisas (ou do nome das coisas) está sempre ligada ao ato de autoridade de quem nomeia. É a violência de quem domina que impõe a nomeação, o sentido, e por fim, o valor das coisas.

Por conseguinte, para Nietzsche não há nada próximo a uma Lei moral transcendente que discrimine a priori o Bem do Mal. Muito menos existe qualquer necessidade de respeito a essa Lei como imperativo incondicional da ação humana. Ele pensava que o que chamamos de ética é pura e simplesmente obediência; um instinto ligado à condição gregária do homem comum. Como explica Oswaldo Giacoia Junior: "Os costumes obrigam à obediência em virtude de uma autoridade que se impõe não em função daquilo que comanda, por exemplo, pela utilidade do que é prescrito, mas unicamente porque comanda. Para Nietzsche, eticidade é veneração à sacralidade dos costumes." (Giacoia Jr, 2012, p. 155).

A genealogia de Nietzsche pretende realizar uma história da moral levando em conta a vaidade, a astucia, os disfarces e as rapinas que acompanham as palavras. Deve-se ressaltar, porém, que a violência originária dos valores tem um sentido amplo. Pode significar desde a imposição pela força bruta, até a ruptura moral pela destruição criativa dos valores hegemônicos. O que importa para Nietzsche é que "todos os criadores são duros" (Nietzsche, 1999, p.94).

Numa famosa passagem, Deleuze explica como Nietzsche poupa o filósofo de ser um juiz de tribunal à maneira kantiana ou um mecânico utilitarista, ao propor-lhe a genealogia:

Nietzsche substitui o princípio da universalidade kantiana, bem como o princípio da semelhança, caro aos utilitaristas, pelo sentimento de diferença ou de distância (elemento diferencial). 
Genealogia quer dizer ao mesmo tempo valor da origem e origem dos valores. Genealogia se opõe ao caráter absoluto dos valores tanto quanto ao seu caráter relativo ou utilitário. Genealogia significa o elemento diferencial dos valores do qual decorre o valor destes. Genealogia quer dizer, portanto, origem ou nascimento, mas também diferença ou distância na origem. (Deleuze, 1976, p.2)

Para Deleuze, a genealogia almeja se desamarrar dos empreendimentos metafísicos e utilitaristas de um modo não reativo. Sua crítica, portanto, deve ser sinônimo de criação e expressão ativa de um modo de ser. ${ }^{28}$

Foucault, por sua vez, compreende a genealogia como um trabalho de demarcação da singularidade dos acontecimentos. Para ele trata-se de "espreitálos onde menos se os esperava e naquilo que é tido como não possuindo história os sentimentos, o amor, a consciência, os instintos" (Foucault, 1986, p.15). Ele também enfatiza o caráter criador da empresa. O que, no seu caso, significa dizer que a análise genealógica almeja menos desvelar a verdade de acordo com uma linguagem neutra do que acrescentar verdades estranhas à solenidade da história hegemônica.

Em uma passagem recheada de citações de Nietzsche, Foucault explica sua ideia:

(...) se o genealogista tem o cuidado de escutar a história em vez de acreditar na metafísica, o que é que ele aprende? Que atrás das coisas há 'algo inteiramente diferente': não seu segredo essencial e sem data, mas o segredo de que elas são sem essência, e que sua essência foi construída peça por peça a partir de figuras que lhe eram estranhas. A razão? Mas ela nasceu de uma maneira inteiramente 'desrazoável' - do acaso. A dedicação à verdade e ao rigor dos métodos científicos? Da paixão dos cientistas, de seu ódio recíproco, de suas discussões fanáticas e sempre retomadas, da necessidade de suprimir a paixão - armas lentamente forjadas ao longo das lutas pessoais. E a liberdade, seria ela, na raiz do homem o que o liga ao ser e à verdade? De fato, ela é apenas uma 'invenção das classes dominantes'. O que se encontra no começo histórico das coisas não é a identidade ainda preservada da origem - é a discórdia entre as coisas, é o disparate (Foucault, 1986, p.18).

\footnotetext{
${ }^{28}$ A interpretação deleuziana da genealogia de Nietzsche tem como base o que ele nomeia de "teoria das forças". Segundo essa teoria, a tarefa do genealogista seria a de interpretar o movimento das forças em determinado contexto: "o sentido de alguma coisa é a relação desta coisa com a força que se apodera dela, o valor de alguma coisa é a hierarquia das forças que se exprimem na coisa enquanto fenômeno complexo" (DELEUZE, 1976, p.6). Essa teoria (assim como o conceito de "diferença" correlativo) tem grande afinidade com os estudos que contemplam a temática da alteridade e das identidades sob a ótica antropofágica. Como afirmei anteriormente, optei por não aprofundar este debate no trabalho.
} 
Não há dúvida de que os ensaios antropofágicos desenvolvem, ao menos parcialmente, a tarefa do genealogista. Oswald exerce a incompletude com plenitude, sem nenhuma má-consciência. Seus textos são abertamente erráticos como suas ideias. Vão e voltam sem obedecer às linearidades das metodologias tradicionais. Invenção e interpretação são indistintas e os conceitos se produzem pela contaminação recíproca do seu estilo e dos autores que recorre. Personalismo, contradição, dramatização são ingredientes comuns.

Para Roberto Corrêa dos Santos:

Entre nós, Oswald parece ter sido o primeiro a absorver e a atualizar a reflexão nietzschiana. Sua cinematografia literal - sua escrita - revela-nos essa 'faculdade de crescer por si mesmo, de transformar e assimilar o passado e o heterogêneo, de cicatrizar as feridas, de reparar as perdas, de reconstruir as formas destruídas' tal a definição de Nietzsche para o valor da força plástica. (Santos, 1999, p.72)

A escrita que Oswald desenvolve pelas rachaduras da história (o seu uso da história) segue o itinerário nietzscheano quando denuncia os afetos e as lutas que fundam os significados, a despeito de suas pseudo origens metafísicas. Nos ensaios, a metafísica (seja ela judaica, cristã, platônica, kantiana, etc.) é apresentada no invólucro do patriarcado messiânico. Segundo Oswald, Nietzsche foi um dos que lhe mostraram "o obscuro compromisso que o homem traz arraigado em sua psique para com todas as miragens que lhe propõe" (OA, 1991, p.249). Fazendo uso do que estamos chamando de "genealogia antropofágica", ele procura interpretar as máscaras discursivas do patriarcado.

Ao lado de Nietzsche, Oswald creditava a Marx um papel de igual importância na crítica moderna ao dogmatismo metafísico.

$\mathrm{O}$ advento do marxismo assinala a maturidade do homem. Porque, consciente de suas forças, ele abjura do conceito de Deus. No mesmo momento em que Carlos Marx, voltado para a prática revolucionária, movimenta a alavanca das Internacionais do Trabalho, um outro privilegiado, esse um poeta, anunciava ao mundo, pela boca de Zaratustra, a morte de Deus. Era Frederico Nietzsche.

Deus foi alvo fácil. Em nome dele tinham-se consumado as aflitivas e criminosas infâmias que haviam garroteado indivíduos e classes ao mando de aristocracias satisfeitas e duras (...).

Mas, com surpresa, vimos um renascimento pertinaz se apossar mesmo dos países mais avançados, tendente a restabelecer não as formas caducas deste ou daquele 
culto, mas a religião em si, renascimento que evidentemente se aproveitaram os sacerdócios em crise. Nenhum argumento maior do que este para se estabelecer que o homem possui uma dimensão religiosa, ligada aos seus instintos e desenvolvida pelos seus reflexos. Dimensão esta que talvez constituía uma das bases da floração do próprio marxismo ateu. (OA, 1991, p. 234)

Na hipótese antropofágica, Nietzsche e Marx são duas facetas da mesma reivindicação: a do homem contra Deus. Oswald, no entanto, constata que o ateísmo do século XIX não vingou. Ao invés disso, a devoção religiosa parecialhe ter se transferido para as "liturgias" e as "divindades" laicas do século XX, manifestadas no comunismo, no fascismo e na cultura de massas. Isto o leva a cogitar a existência de uma dimensão religiosa imanente, natural e primitiva no homem. Para ele, tal religião correspondia à religiosidade sem Deus do matriarcado. O resultado é que Nietzsche e Marx serão apresentados como dois aspectos da mesma revolta matriarcal contra o patriarcado.

Aqui começa a excentricidade da proposta oswaldiana. Pois, ainda que se queira procurar religiosidade no pensamento de Nietzsche (Zaratustra, Dionísio), dificilmente se encontrará síntese, escatologia ou redenção coletiva, tal como se apresenta na literatura marxista. Como vimos, a genealogia foi empreendida por Nietzsche justamente como um método de análise que salvaguardasse o matiz histórico de qualquer Lei intrínseca, fosse ela transcendental ou materialista.

Segundo Deleuze, isso basicamente significa que a filosofia de Nietzsche tem um caráter "resolutamente anti-dialético" (Deleuze, 1976, p.9) ${ }^{29}$

Afora isso, podemos interpretar o pensamento de Nietzsche de vários pontos de vista, mas não podemos ignorar que ele próprio o caracteriza como uma filosofia da potência. Vez por outra, essa filosofia expõe seu braço político. Nietzsche não tem nenhuma restrição à escravidão, à hierarquia de classe, ao aristocratismo, etc.. Pelo contrário, estas divisões lhe parecem fundamentais para a preservação de uma cultura saudável.

Está claro que ele redefine o sentido de senhor/escravo como afirmação/negação da vida. Com isso, estende o dualismo hegeliano para além do

\footnotetext{
${ }^{29}$ Com exceção, talvez, de A Origem da Tragédia, a qual o próprio Nietzsche afirma que "cheira a hegelianismo de forma escabrosa", e que Deleuze concorda, explicando que o livro "desenvolve as antíteses entre Apolo e Dionísio à sombra das categorias dialéticas cristãs de redenção e reconciliação" (DELEUZE, 1976, p. 9).
} 
princípio de representação. Em outros termos, para Nietzsche os jogos de poder não se dão apenas na esfera dos atores históricos com funções socialmente instituídas. Esta já seria a interpretação do escravo que, incapaz de criar seus próprios valores, reconhece o embate do poder nos valores pré-estabelecidos.

Em consequência, Nietzsche julga qualquer discurso humanista, iluminista, socialista ou apenas simpático aos princípios democráticos modernos como uma negação da vida e um sinal de decadência. Ele via o empenho moderno pela igualdade de direitos políticos como uma mediocrização, um apequenamento do homem. Primeiro, porque defendia a singularidade dos indivíduos contra a uniformidade moral; segundo, porque entendia que: "o ódio aos de origem plebeia é um fator típico da moral dos potentes" (Nietzsche, 1992, p.198).

A citação abaixo faz parte da sessão "O que é Nobre?" de Além do Bem e do Mal. Nela, Nietzsche expõe sem rodeios sua posição política que, podemos adiantar, tem grande afinidade com o que Oswald definia como mentalidade patriarcal, e que tanto deplorava:

Toda a elevação do tipo "homem" foi, até o momento, obra de uma sociedade aristocrática - e assim será sempre: de uma sociedade que acredita numa longa escala de hierarquias e diferenças de valor entre um e outro homem, e que necessita da escravidão em algum sentido (...).

Quando uma aristocracia, como a da França no começo da Revolução, descarta com sublime nojo seus privilégios e se sacrifica a um excesso do seu sentimento moral, isto é corrupção - foi na verdade, apenas o ato final de uma corrupção de séculos, através da qual ela cedera pouco a pouco suas prerrogativas senhoriais e se rebaixara a uma mera função da realeza (e enfim até mesmo seu ornato e aparato). O essencial numa aristocracia boa e sã, porém, é que não se sinta como função (quer da realeza, quer da comunidade), mas como seu sentido e suprema justificativa - que, portanto, aceite com boa consciência o sacrifício de inúmeros homens que, por sua causa, devem ser oprimidos e reduzidos a seres incompletos, escravos, instrumentos. Sua fé fundamental tem de ser que a sociedade não deve existir a bem da sociedade, mas apenas como alicerce e andaime no qual um tipo seleto de seres possa elevar-se até sua tarefa superior e um modo de ser superior (...). (Nietzsche, 1999, p.169-170)

Nada mais inadequado ao cenário dos ensaios oswaldianos, no qual se pode encontrar copiosamente distribuídas as aspirações socialistas de igualdade social e os devaneios com a harmonia coletiva. Nada mais distante da revolta 
insistentemente repisada por Oswald contra os privilegiados de todos os tempos ${ }^{30}$. Por conseguinte, embora o selo da genealogia nietzscheana seja nítido na antropofagia, paradoxalmente, seus desdobramentos sociais e políticos distanciam Oswald e Nietzsche.

Não pretendo aqui cometer a ingenuidade de fazer um julgamento totalizador do complexo pensamento de Nietzsche a partir de um fragmento isolado. O erro de forjar um Nietzsche light é proporcional ao de fixar um Nietzsche hard. Nos dois casos, perde-se de vista o contexto de suas provocações e ironias. Quero apenas ressaltar um aspecto político do seu olhar para a modernidade que, a meu ver, é mal avaliado por Oswald.

É comum a reprodução da crítica nietzscheana ao igualitarismo teórico do pensamento humanista-iluminista. Mas são mais raros os comentários sobre suas opiniões a respeito da burguesia e da democracia. Em termos especificamente políticos, Nietzsche não se aprofundou nas ambivalências ideológicas resultantes das novas condições de produção e consumo (industrialização, especialização, mundialização). Com isso, manteve uma concepção arcaizante de aristocracia e de democracia, sem diagnosticar a fundo as implicações das novas versões de "senhores e escravos" no dinâmico choque entre pobres e ricos no capitalismo.

Oswald percebe isso de forma apenas parcial, pois, seu inabalável utopismo social encontra um meio exótico de adaptar Nietzsche ao comunismo.

\begin{abstract}
Para iniciarmos os estudos sobre Marx e Nietzsche, os dois gigantes que despertaram a consciência dos tempos novos, convém assinalar um equívoco monstruoso que os separou no julgamento dos valores atuais da sociedade e da História. Nietzsche, quando anunciava o super-homem, ignorava que este seria simplesmente o proletário, saído das páginas religiosas do grande "Manifesto" de Marx e Engels. Perdido nas alturas de Sils-Maria, ele não podia tomar conhecimento das transformações sociais que processavam sob suas vistas. Evidentemente o socialismo que atacou e satirizou não era o mesmo que criava uma das maiores expressões da vontade de domínio, Vladimir Ilitch Ulianov, ou seja, Lênin.(...) (OA, 1991, p. 250-251)
\end{abstract}

\footnotetext{
${ }^{30}$ Ao longo da tese, veremos que Oswald foi bastante crítico ao tipo de uniformização proposta por certas correntes revolucionárias. Especialmente no que se refere ao constrangimento político de intelectuais e artistas em nome de supostas reformas sociais. Entretanto, não existe nada vagamente próximo à defesa de uma hierarquização (mesmo que espiritual) no modelo nietzscheano em seus ensaios.
} 
Alguns podem insistir no argumento de que Nietzsche tinha uma concepção trágica da justiça, e que sua visão política só pode ser compreendida do ângulo anti-representacionista ${ }^{31}$ (como uma dinâmica de intensidades, forças, etc). É possível. De qualquer forma, o que importa observar aqui é que o antirepresentacionismo de Oswald não tinha nada de resoluto. Com efeito, na maior parte das vezes em que se refere à "moral dos escravos", ele adapta o conceito de Nietzsche ao âmbito marxista da opressão de classes. Ela aparece isoladamente como um artefato das elites patriarcais. Em nenhuma ocasião menciona as acepções nietzscheanas que, se não são as únicas, indiscutivelmente integram a definição da "moral de rebanho". A saber: moral plebeia, popular, doente, piedosa, compassiva, reflexo da fraqueza e do medo constitutivo da maioria, do homem comum.

A impressão que dá é que Oswald subsumiu (ou distorceu) a ética humanista-iluminista na guerra particular de Nietzsche contra os sacerdotes e contra a metafísica. Parece que ele enxergava alguma identificação entre os libelos de Nietzsche e as apostas modernas na auto-suficiência da espécie humana (sem Deus), na solidez crítica, construtiva e mediadora da razão, e no sonho de que, livre de coações (naturais e institucionais), os homens floresceriam. ${ }^{32}$

O resultado é que, na antropofagia ensaística, a divisão entre senhores e escravos segue o modelo político iluminista do conflito entre oprimidos e opressores, com Oswald tomando inequívoco partido em favor dos primeiros, e arquitetando uma utopia coletivista e anti-classicista ${ }^{33}$.

\footnotetext{
${ }^{31}$ Em defesa desse ponto de vista cito outro texto de Oswaldo Giacóia Jr : "O principal malentendido consiste justamente nesse erro de interpretação, que identifica o essencial da filosofia de Nietzsche com sua crítica da modernidade política. É certo que essa crítica existe e que algumas de suas figuras são, efetivamente, problemáticas, decididamente anti-humanitárias; mas não é menos certo que ela é apenas uma faceta ou consequiência da crítica da moral e da crítica da cultura empreendidas por Nietzsche, uma espécie de sub-produto de sua tentativa de "refutação genealógica" do Cristianismo e de transvaloração de todos os valores superiores da cultura ocidental" (GIACOIA JR, 2012b)

${ }^{32} \mathrm{~A}$ inconsistência de Oswald tem dois efeitos colaterais curiosos. O primeiro é a dúvida que recai sobre os limites da oposição de Nietzsche ao humanismo-iluminista. Até que ponto Nietzsche é realmente independente dos ideais modernos? Caso o seja integralmente, surge a segunda dúvida: será que podemos, de fato, ser nietzscheanos sem deturpá-lo para uma versão levemente contaminada pelos ideais democráticos modernos?

${ }^{33}$ Para efeito de ilustração, um breve e explícito exemplo dos inumeráveis brados comunistas que se pode encontrar nos ensaios. Este é de 1950: "Nunca nos eliminarão da onda que dia a dia se avoluma sob as bandeiras tanto de Marx como de Proudhon, na direção do mundo transformado e sem classes, de um mundo socialista, de um mundo melhor!" (VNL, 1991, p.230).
} 
Assim, da mesma forma que mergulhava na genealogia, concebendo a política como reflexo da moral, Oswald também percorria o caminho contrário, situando a moral como resultado da política. Nesses casos, infiltrava-se pela dialética em busca de explicações universalistas da História (com h maiúsculo) que fornecessem sínteses para o progresso da humanidade. ${ }^{34}$

\section{4. \\ Dialética antropofágica}

Nos ensaios, é frequente encontrarmos Oswald postulando o fundamento real das contradições. Em 1945, nos primeiros anos de retomada da antropofagia, sustentava que: "Hegel, no que tem de excelente, dizia que a contradição existe na raiz do próprio movimento. Vida é contradição, vida é conflito. E, na formulação dos atuais temas da Antropofagia, é a dialética o seu maior instrumento" (IM, 1991, p.103).

Cinco anos mais tarde, em A crise da filosofia messiânica, desenvolve a intuição. Para ele, a "revolução copernicana" de Kant, no fundo, revigorava Platão, apenas adequando seu idealismo à noção de conceito. Admite, todavia, que apesar da "máscara ecumênica" de sua Lei Moral, o criticismo e as antinomias kantianas abriam caminho para a dialética hegeliana. É a partir desta, afirma ele, que "se desmascara o processo de Negatividade. Em Hegel historicializa-se o progresso pela negação. Nos sistemas fechados do pensamento, Hegel introduz uma nova dimensão - o tempo" (CFM, 1972, p.114).

\footnotetext{
34 Marilia Rothier Cardoso pensa diferente, e afirma que: "A retomada da vanguarda "antropofágica", em tese e ensaios, vinte anos depois do Manifesto, conserva o estilo fragmentário, num ostensivo descarte da tradição lógico-discursiva, ainda que experimente alguns raciocínios de aparência dialética, acompanhando o prestigio da linhagem marxista, naqueles meados de século. A economia poético-humorística dos textos reforça o teor um tanto desconcertante das propostas, alheias seja ao controle da linearidade fonocêntrica da escrita, seja ao fechamento da disciplina dialética" (CARDOSO, 2011/12). Concordo que não se pode comparar os ensaios de Oswald às rígidas metodologias dos marxistas ortodoxos ou da historiografia tradicional. Todavia, como pretendo argumentar ao longo da tese, penso que, nos ensaios, a consciência da linguagem antirepresentacionista é complementar (e não excludente) à argumentação narrativa e logocêntrica.
} 
No mesmo texto, Oswald expõe o que entende como sendo a lógica do processo de negatividade:

Vivemos em estado de negatividade, eis o real. Vivemos no segundo termo dialético da nossa equação fundamental.

O exegeta de Hegel, Kojeve, afirma que o homem é inicialmente "natureza inata, ser natural de caracteres fixos, animal especificamente determinado que vive no seio da natureza tendo aí seu lugar natural". Eis o primeiro termo.

Comentando Kojeve, um pensador católico, R. Vancourt, elucida o segundo termo: "O homem não é homem senão pela sua negatividade, isto é, no quanto ele nega esse dado no quanto ele se nega a si mesmo como dado, enquanto como natureza e liberdade, ele constitui precisamente essa negação do dado e assim se manifesta pelo trabalho e no trabalho" (CFM, 1972, p. 80)

Parafraseando Marx, Oswald afirma reiteradamente que "o Homem transforma a natura e fazendo isso transforma a sua própria natureza" (OA, 1991, p. 277). Somos o resultado do trabalho, isto é, das nossas relações com a natureza. Transformamos os objetos quando agimos sobre eles, o que faz como que nossa realidade (incluindo nós mesmos e nossas ideias) deixe de ser estática, passando a responder a um movimento dialético. Conforme a tese hegeliano-marxista, as contradições da consciência, seu movimento entre "prós e contras", "sins e nãos", têm um fundamento real. "As realidades apresentam não somente aspectos múltiplos, mas facetas mutáveis e contraditórias” (Lefebvre, 2011, p. 28)

Marx conduz esse paradigma para uma explicação materialista. Lembremos, por alto, o célebre argumento. Tão logo o ser humano sai do estágio natural, a produção dos meios de vida (comida, abrigo, ferramentas) torna-se uma atividade social, que acarreta a dependência mútua dos indivíduos. A posição que cada sujeito assume em relação a essa produção indica aqueles com quem partilha interesses e aqueles com quem está em conflito. Contudo, os meios de produção estão em contínua transformação, alterando a relação dos indivíduos com a produção e, consequentemente, de uns com os outros.

Para Marx, portanto, era "óbvio que a verdadeira riqueza espiritual do indivíduo depende totalmente da riqueza de suas relações reais. (...) Aqui fica claro que os indivíduos se fazem uns ao outros, tanto física quanto espiritualmente, contudo não se fazem a si mesmos" (Marx, 2007, p. 61). 
Como se sabe, sua intenção era rejeitar as teorias idealistas e deslocar a explicação da origem metafísica da história e da consciência para as relações empíricas (e dialéticas) entre os seres humanos:

Esta concepção, diferentemente da idealista, não busca uma categoria em cada período, mas se mantém sempre sobre o terreno histórico real; não explica a prática partindo da ideia, mas explica as formações ideológicas sobre a base da prática material, através do que chega, consequentemente, também ao resultado de que todas as formas e todos os produtos da consciência não podem ser destruídos por obra da crítica espiritual, mediante a redução à "autoconsciência" ou à transformação em "fantasmas", "espectros", "visões" etc., mas tão-somente podem ser dissolvidas com a derrocada prática das relações reais, das quais emanam essas quimeras idealistas - de que a força propulsora da história, inclusive a da religião, da filosofia e de toda a teoria, não é crítica, mas sim a revolução. (Marx, 2007, p. 62)

Oswald adota, parcialmente, a ideia de que o universo simbólico é engendrado pelas relações dialéticas da realidade prática. Ele enfatiza, sobretudo, um significado específico da "negatividade", que é o trabalho coercitivo e a escravidão. Sustentava que "da servidão derivou a divisão do trabalho e a organização da sociedade em classes. Criou-se a técnica e a hierarquia social. E a história do homem, passou a ser, como disse Marx, a história da luta de classes" (CFM, 1970, p.81).

Nos próximos capítulos, veremos como Oswald vai metaforizar a guerra de classes no conflito entre o matriarcado e o patriarcado, adaptando a teoria de Marx aos seus propósitos. $\mathrm{O}$ antagonismo ganha versatilidade ao ser diagnosticado nos incontáveis fatos históricos que ele revisa, assim como nas presumidas qualidades matriarcais e patriarcais que reconhece no sujeito moral das diferentes épocas.

Até 1954, o olhar antropofágico-dialético esteve presente na maneira como Oswald explora os eventos históricos. Isso fica particularmente visível quando enumera as liberdades e os ganhos civilizatórios decorrentes dos fenômenos patriarcais que ataca, tais como o socratismo, o protestantismo e a burguesia renascentista. Além disso, em alguns casos, analisa as facetas matriarcais e patriarcais convivendo dialeticamente no mesmo evento, como é o caso do cristianismo antigo e do feudalismo. 
Dito isto, um dos maiores desafios na leitura dos ensaios são as bruscas mudanças de marcha. Quando os textos parecem se encaminhar com docilidade para a convicção metafísica na síntese entre matriarcado e patriarcado pelo passe de mágica da técnica, nos deparamos com abruptas interrupções. Com a mesma rapidez que nos empurra para os terrenos absolutos da escatologia marxista, Oswald nos traz de volta à suspensão cética e irônica, demonstrando que não era de todo resignado as versões transcendentais da dialética.

Como o saber moderno abandonou os absolutos senão o Absoluto, e isso se choca com o monolito soviético com que o marxismo-leninismo enfrenta a agonia capitalista, acontece que o Dogma, a Certeza, a Infantilidade Sectária, passaram para o lado dos vermelhos, enquanto a revolução ficou modestamente a cargo da "ciência burguesa". Aqueles se tornaram obtusos e agressivos como cães danados da defesa idealista de suas convicções (...).

Os comunistas utilizam, porém, todo o já velho vocabulário com que realmente abalaram em dez dias o mundo. Assim, a palavra Dialética pertence ao seu tesouro.

Dialética exprime mudança, diálogo, oposição pela qual se atinge um progresso ou uma síntese. Mas para eles, Dialética é hoje uma empedernida barreira que ergueram na defesa metafísica das suas posições ultrapassadas.

Do lado burguês, no entanto, a Certeza passou a ser condicionada. As próprias ciências chamadas exatas não afirmam mais coisa alguma de rigoroso. É, não é, pode ser. Um jogo dialético...(TEL, 1996, p. 346).

É interessante notar a ambiguidade que envolve os ensaios no tocante a Marx. De certa forma, uma das grandes diferenças desses textos para a etapa modernista é o eco mais intenso das ideias do autor de $O$ Capital. No entanto, se olharmos para os quinze anos intermediários (de militância comunista), o retorno à antropofagia é também uma violenta crítica ao marxismo ortodoxo. Principalmente por conta do desenrolar dos acontecimentos na URSS (e a submissão do PCB à "Moscou"), que o levaram a repensar uma série de questões a respeito do marxismo teórico e prático.

Sem abandonar de todo as formulações de base da filosofia marxista, Oswald passa a criticar alguns aspectos dogmáticos da mesma. Ele começa a apontar como a intransigência anti-idealista se incorpora aos axiomas "científicos" formando uma espécie de metafísica revolucionária. Em função disso, assume uma atitude dúbia em relação a Marx, oscilando entre a afirmação e a negação. 
Encontramos a apologia da ligação marxista entre economia e história no mesmo parágrafo em que censura o seu "corte minúsculo na História, colocando as origens do capitalismo na revolução industrial" (AM, 1972, p.208). Em alguns momentos, Oswald retrata o Manifesto Comunista com devoção dramática, sublinhando o seu "lirismo inovador capaz não de transformar, mas de engolir o mundo" (AO, 1991, p.247); A seguir, condena sem piedade a doutrina autoritária e messiânica de $\operatorname{Marx}^{35}$.

Finalmente, na conferência "Velhos e Novos Livros" (1950), se detém mais minuciosamente no debate, alegando que estava na hora de procurar alternativas para os que se desiludiram da dogmática marxista. Entre outras hipóteses, ele considera os possíveis ganhos de uma revisão do socialismo utópico de Proudhon, em vista do que, compara os dois autores e as culturas opostas que expressam:

\begin{abstract}
A primeira, a de Marx, trazendo um aspecto apocalíptico e messiânico que lembra suas origens hebraicas. A outra, a de Proudhon, mediterrânea e clara, dubitativa e profunda demais para se alastrar pela superfície das revoluções armadas e das conjuras pretorianas. É uma revolução de gabinete. Mas é nela que hoje, num crescente renascimento, se busca o antídoto contra o execrável e teimoso sectarismo dos marxistas. (...)

Essa vantagem leva o mestre revolucionário da França sobre o inexorável profeta judeu-alemão. Proudhon foi um fino psicólogo social e talvez deva a isso o retardamento de sua decisiva importância. Era tão urgente a transformação do mundo - tal o atraso agressivo que foram longa e milenariamente deixadas as classes trabalhadoras e úteis da sociedade - que somente as teses autoritárias e simplistas do marxismo podiam ter agido com êxito nesta primeira metade convulsa do século XX. Toda função crítica podia ser acoimada de suspeita no momento de grande investida socialista. (VNL, 1991, p. 216-217)
\end{abstract}

Oswald é mais chegado ao delírio do que a sensatez. Mas nesse caso, em particular, demonstrou coerência ao defender Proudhon. Tudo o que Marx mais desprezava no francês era a mistura de utopismo e ignorância econômica, componentes vivos na antropofagia. Para Marx, essas eram características do socialismo burguês e reformista, que almejava "as condições de vida da sociedade

\footnotetext{
35 Em uma de suas tradicionais boutades, Oswald psicologiza Marx, no mais puro estilo nietzscheano: "Não se deve esquecer que Karl Marx foi um professor fracassado de universidade. $\mathrm{O}$ seu intuito inicial era obter uma cátedra de filosofia. Esse recalque havia de estourar o mundo burguês." (VNL, 1991, p. 225). Ironicamente, no mesmo ano em que zomba de Marx, Oswald tentaria obter a sua cátedra de filosofia na USP, sem sucesso.
} 
moderna sem as lutas e perigos necessariamente decorrentes. Almejam a sociedade atual, eliminando, porém, os elementos de revolução e de dissolução" (Marx, 2001, p.74). ${ }^{36}$

O filósofo social judeu Martin Buber explica que Marx e Engels podiam até atenuar os ataques aos primeiros utopistas (Fourier, Saint-Simon e Owen), por considerar que suas ideias precediam ao real desenvolvimento da indústria, do proletariado e da luta de classes. Todavia, no que se refere aos socialistas utópicos contemporâneos, a detração era implacável. Todos eram acusados de idealistas, metafísicos, pequenos burgueses e daí para baixo.

Segundo Buber, porém, a despeito da hostilidade para com os utopistas, era inegável que o marxismo também nutria sua própria utopia. Mais do que isso, no que concerne às metas finais, a utopia marxista não divergia essencialmente daquelas que depreciava. O abismo entre os dois tipos de utopia estava no processo. No trajeto imaginado pelas teses marxistas;

No caminho que conduz à revolução e à época subsequente à revolução, caminho que se caracteriza por um centralismo total e que não tolera nenhum aspecto ou iniciativa que não sejam os seus. Misteriosamente, a uniformidade como caminho leva à diversidade como meta final; e, misteriosamente, a coação como caminho leva à liberdade como meta final. O socialismo "utópico" não marxista, pelo contrário, busca um caminho substancialmente idêntico à sua meta final. Ele se nega a crer que, confiando no "salto" que será dado algum dia, se deva preparar entrementes, o contrário daquilo que se deseja alcançar (Buber, 2007, p.24).

Obviamente Oswald não podia concordar com o dogmatismo "científico" de Marx. Conquanto não seja raro encontrar bravatas revolucionárias nos ensaios

\footnotetext{
${ }^{36}$ Em várias situações Oswald explicita seu desejo por uma aliança de forças, por uma síntese pacífica entre a burguesia progressista e o proletariado, entre URSS e EUA, etc.. Em 1947, por exemplo, escreveu uma crônica intitulada Porque deixei o Partido Comunista. Depois de relatar com indignação e escárnio o caso em que foi espionado sob a alegação de "vigilância de classe", Oswald comenta os motivos ideológicos que o fizeram sair: "O que me interessava, em termos mais vastos, era aceitar a dissolução por Stálin da III Internacional, historicamente ultrapassada, e seguir a linha americana de Earl Browder, que era a linha da síntese das forças progressistas burguesas com as forças socialistas, a mesma que dera o acordo de Teerã e produzira a vitória sobre o nazismo. Porque não desenvolver a paz na linha que ganhara a guerra? Ao contrário disso, a direção do PCB achava dialético adotar não o último termo da equação política hegelianomarxista, isto é Teerã, mas sim retornar ao sectarismo ultrapassado do primitivo bolchevismo, ao seu surto belicoso e internacionalista" (TEL, 1996, p.208).
} 
(algumas constrangedoras) ${ }^{37}$, nada pode ser mais estranho à antropofagia do que a ideia de um "caminho único". Aqui, como acontece com Nietzsche, Oswald assume boa dose dos princípios conceituais e críticos do autor, mas se desvia no efetivo trajeto de seu pensamento político. No caso de Marx, contudo, Oswald mostra ter mais consciência de suas divergências do que no caso de Nietzsche.

Acontece que, para a antropofagia, o Estado não era o Estado Moderno capitalista. Também não era o Estado Russo, nem o Americano, nem o Estado Novo getulista. Eram todos eles juntos. O Estado para Oswald era o Patriarcado. Era a alegoria do monopólio dos meios de violência. A metáfora do discurso messiânico de repressão da sexualidade e do espírito lúdico.

Os conceitos que Oswald põe em jogo flertam, às vezes, com o teor metafísico teleológico que o marxismo, apesar de seu férreo anti-idealismo, pode assumir. Todavia, nem existe ortodoxia, nem nenhuma doutrina política "científica", "realista", "materialista" ou "econômica" na antropofagia.

Assim sendo, quando Oswald chama Proudhon à cena novamente, é para relembrar as desavenças pessoais entre ele e Marx. Dessa vez, aproxima definitivamente o utopista francês da antropofagia:

Proudhon, sendo também um panfletário, tinha, no entanto, outra largueza de espírito e outra formação humanística. Ficará como um dos maiores documentos da história das idéias aquela carta em que o filósofo francês responde negativamente ao convite que Marx e Engels lhe dirigem querendo enquadrá-lo na militância do primeiro marxismo ${ }^{38}$. Proudhon confessa aí que seu forte não é o dogmatismo nem a intolerância. E nisso se levanta hoje o pedestal de sua Glória. Enquanto Marx é imperativo e radical, Proudhon é dubitativo e humano (...).

\footnotetext{
${ }^{37}$ Um exemplo: "Todas as patacoadas do cristianismo têm que ser destruídas a ferro e fogo, pois não é argumento buscar nelas reservas e arsenais ideológicos contra Rússia Soviética. Esta errou na sua trilha revolucionária e pagará espetacularmente os seus desvios. É preciso enforcar, como queria a Revolução Francesa, o último padre, na tripa do último nobre, para termos, enfim, um mundo digno das conquistas da consciência e da liberdade" (OA, 1991, p.276)

${ }^{38}$ A correspondência é reproduzida por Martin Buber: "Marx convidou Proudhon a participar de uma 'correspondência' que serviria para 'um intercâmbio de ideias e para uma crítica imparcial' e para qual - escreve Marx - 'é nossa opinião unânime que, no que se refere à França, não poderíamos encontrar melhor correspondente do que V.S.', Proudhon respondeu nos seguintes termos: 'Procuremos conjuntamente, se V.S. o deseja, as leis da sociedade e a maneira como essas leis se convertem em realidade; mas, pelo amor de Deus, após havermos removido os entulhos de todos esses dogmatismos a priori, não queiramos, por nossa parte, envolver o povo com doutrinas. Não nos convertamos, pelo fato de estarmos à frente de um movimento, em chefes de uma intolerância; não nos comportemos como apóstolos de uma nova religião, mesmo que essa religião seja a da lógica e da razão' (BUBER, 2007, p.24)
} 
Com outro genial pensador do século XIX, que ele não conheceu e que também não o conheceu - o dinamarquês Kierkegard - Proudhon formula o pensamento fundamental das teogonias primitivas - "Deus é o mal!" (VNL, 1991, p.227).

A passagem nos permite entrever a estratégia de Oswald. Se o comunismo fracassou, a utopia socialista continuava viva. O que ela precisava era ser deslocada do dogmatismo para o terreno fértil do pensamento matriarcal e do “estoicismo" primitivo. É nesse ambiente que ele julgava ser possível conciliar Nietzsche e Marx: "O que escapou à observação de Nietzsche, como à de Marx e de Engels é que havia um potencial de primitivismo recalcado por séculos sob o domínio fraco das elites burguesas." (OA, 1991, p. 250-251)

É difícil definir com precisão o que Oswald identificava como primitivismo. Era um vitalismo cético? Uma religiosidade imanente? O freio contra os desmandos do Estado? As pulsões reprimidas pela civilização? Provavelmente isso tudo e um pouco mais.

O certo é que ele procurava uma chave para os antagonismos entre a autonomia individual e os interesses coletivos. E a resposta que encontrou, nós conhecemos, era a antropofagia. Seja como potência ou como modus operandi, em toda a sua incompletude polissêmica, transvalorativa, contingente e transigente.

É preciso dar o passo de Nietzsche na direção do Super-homem. Atingir a filosofia da Devoração. A antropofagia. "Única lei do mundo. Expressão mascarada de todos os individualismos, de todos os coletivismos, de todas as religiões, de todos os tratados de paz". A transformação do tabu em totem.

O antropófago habitará a cidade de Marx. Terminados os dramas da pré-história. Socializados os meios de produção. Encontrada a síntese que procuramos desde Prometeu. Quando terminarem os últimos gritos de guerra anunciados pela era atômica. Porque "o homem transformando a natureza transforma a sua própria natureza" Marx (...)

"O método dialético exige que os fenômenos se examinem não só do ponto de vista de suas relações mútuas e de seu mútuo condicionamento, mas também do ponto de vista de seu movimento, de suas transformações e de seu desenvolvimento, do ponto de vista do seu nascimento e de sua morte". Lênin. Nada existe fora da Devoração. O ser é a Devoração pura e eterna.

O homem nu compreenderá. De volta das viagens ao país do Absoluto, ao país do Tabu. Platão. Aristóteles, Tomás de Aquino, Kant, Hegel. Quando sobre a vitória da técnica e da socialização, ele plantar a bandeira angustiada de Agostinho, de Pascal, de Nietzsche e de Chestov. A bandeira ilógica. (MAD, 1991 p. 286). 
A antropofagia é movimento. Por isso, transita na via de mão dupla que liga a razão (a técnica, a socialização, a crítica) ao ilógico. Nos ensaios antropofágicos, esse fluxo é auxiliado pela ampla variedade de acepções que assume o termo "primitivo". Foi pela manipulação desse conceito errante e ambivalente, que Oswald acreditou ter encontrado um código capaz de aliar o anti-dogmatismo nietzscheano ao idealismo socialista-marxista.

Oswald confiava que: "um largo movimento vai (ia) deixando o caráter ecológico dos estudos culturais para penetrar no campo único de uma cultura do homem, de uma cultura antropológica, onde o inconsciente freudiano alicerça seus direitos." (CD, 1991, p.214). ${ }^{39}$.

A convicção em uma cultura antropológica, ligada às dimensões inconscientes do ser humano leva Oswald a conclusões generalistas, duvidosas e imprecisas. Mas também é um campo aberto para a inventividade e a franqueza do seu pensamento. Não há como separar as inconsistências teóricas das intuições literárias.

No "campo único de uma cultura do homem", Oswald desenvolve significados transcendentes e imanentes, obscuros e transparentes, delirantes e sensatos para as noções de primitivo, órfico, matriarcado, utopia, "homem natural" e antropofagia. Em torno dessas idéias, ele prepara o banquete antropofágico no qual, não apenas Nietzsche e Marx, mas também Montaigne, Kierkegaard, Freud, Proudhon e tantos outros sentam à mesma mesa.

\footnotetext{
${ }^{39}$ Lembremos que nos anos 1950, ainda era popular o argumento da antropologia filosófica, segundo o qual todas as culturas conheciam a dor, o prazer, o trabalho, a sexualidade, a amizade, a inimizade, a linguagem, a culinária, a arte e outros fenômenos universais. Não se ignorava a variedade de sentidos e valores associados a esses eventos em cada cultura. No entanto, a crença de que havia certas estruturas comuns a todas elas encorajava as ciências sociais a perseguir uma meta análoga ao das ciências naturais: o universalismo.
} 


\section{3 \\ O matriarcado, o patriarcado e o homem natural tecnizado}

\section{1. \\ O sentimento órfico}

Em 1954, doente e rendido numa cama de hospital, Oswald de Andrade escreve sobre a morte, o passado e a religião. Entre as sombras da imaginação fragilizada, testemunha a precariedade da vida e a indiferença da realidade com as ilusões. Desamparado, recorre à memória como derradeiro esteio. Mais precisamente, a infância. Só na infância resta-nos algum apoio áureo, diz ele. A infância é a idade de ouro de cada um. Nela entranha-se o que batizou de sentimento órfico.

Todo homem possui uma dimensão psíquica subterrânea e inapreensível. Para Oswald, ela é a fonte da miríade de crenças e liturgias que, no Ocidente, costuma-se generalizar pelo substantivo religião. "Se examinarmos a história tanto a presente como a passada, verificamos que não há povo civilizado ou ajuntamento primitivo que não tenha religião. Somos forçados a anotar esta verdade - a religião é uma dimensão do homem (...)” (OA, 1991, p. 287-288).

Estamos no terreno das especulações essencialistas e universalistas da antropofagia ensaística. Em outro texto, mais ou menos da mesma época, Oswald pondera sobre nossas disposições pré-linguísticas e pré-culturais, sustentando a hipótese de que o homem é um animal deficitário. Segundo essa teoria, o homem, longe de ser a espécie privilegiada, é um das mais vulneráveis da natureza, demonstrando imensa incapacidade de adaptação inicial, exigindo uma penosa formação que depende do auxílio de inúmeros meios para que, finalmente, possa se reproduzir:

O êxito mundial da versão da Gênese explica-se por que de fato ela roça o problema apenas informando-o com a carga ético-religiosa em que o prendem a um credo salvacionista. De fato, o homem é um decaído, mas nunca por culpa ou pecado seu ou de sua companheira. Melhor será dizer que possui uma natureza 
frustrada que não pode prescindir dos recursos de toda técnica de adaptação para viver. Melhor ainda será vê-lo como um animal deficitário, desprovido dos naturais recursos de defesa e de ataque que possuem os outros a fim de subsistir. Daí provenha talvez todo o desenvolvimento excepcional de seu cérebro e, por conseguinte, tanto a sua técnica de comunicação, falar, escrever, criar a roda e a vela, quanto a sua técnica de recuperação mental e psíquica que contém religiões, mitologias, céus, infernos, apocalipses e messianismo (OA, 1991, p.279).

É fundamentalmente sob essas "técnicas de recuperação mental e psíquica" que repousa o inefável sentimento órfico. Ele dá base às construções simbólicas que medeiam nossa convivência com o incompreensível. São os medos e as esperanças que alimentam as nossas crenças, ou, ainda, uma espécie de "religião natural" ou "vontade de crer"

O orfismo foi uma religião de mistérios do mundo antigo, que preconizava a origem divina da alma e a reencarnação. Segundo Walter Burkert, Heródoto identifica Orfeu e Pitágoras como os primeiros fundadores de seitas religiosas no Ocidente, o que representou um grande contraste com a tradicional, mas difusa religiosidade grega anterior. A novidade estaria na introdução de ritos ascéticos e na iniciação de discípulos em mistérios inomináveis (os mistérios de Elêusis ${ }^{41}$ ). Contudo, existem muitas sobreposições envolvendo os seguidores órficos, pitagóricos e báquicos (adoradores de Dionísio), de modo que esta é uma área de demarcação imprecisa da ciência da religião, recheada de informações controversas.

De acordo com o mito, Orfeu era um músico sublime que aprendera a arte da lira com Apolo e que encantava animais, árvores e até os homens mais irascíveis. Certa feita, sua amada Eurídice foi picada por uma serpente. Orfeu, desesperado, tentou salvá-la do Hades (mundo dos mortos), mas não teve êxito, o que o levou a passar o resto da vida desolado. Ele morreria esquartejado pelas mãos das Ménades, as irracionais adoradoras de Dionísio, fato que é explicado por diferentes versões. Burkert nos informa, ainda, que os poemas de Orfeu devem ser

\footnotetext{
${ }^{40} \mathrm{Em}$ outro trecho, Oswald define o sentimento órfico da seguinte maneira: “(...) os fatos deste século apoiam a ideia de que existe uma dimensão religiosa no homem. Isso que os católicos tardiamente reconheceram como religião natural e que os pragmatistas excelentemente chamaram de "a vontade de crer" não passa de uma constante humana, a que daremos o nome de sentimento órfico. (OA, 1991, p. 235)

${ }^{41}$ Culto das Deusas Demeter e Perséfone. "Ligada direta à fertilidade da terra cultivada, Deméter é uma antiquíssima deusa-mãe cuja origem deve remontar, no mínimo, ao neolítico. Perséfone é sua filha." (www.greciantiga.org).
} 
anteriores a Homero e à Guerra de Tróia, pois consta que ele foi um dos participantes da expedição dos Argonautas, na qual tinha a função de apaziguar as ondas e anular o efeito hipnótico do canto das sereias através de sua música.

As comunidades órficas, então, tinham na figura e nos poemas de Orfeu a sua inspiração e seus mistérios. Em um texto de Bertrand Russel sobre as origens do pitagorismo, encontramos outra informação relevante para o nosso assunto. De acordo com o filósofo:

A combinação das matemáticas e da teologia que começou com Pitágoras, caracterizou a filosofia religiosa na Grécia, na Idade Média, e nos tempos modernos, até Kant. O orfismo, antes de Pitágoras, era análogo às religiões asiáticas de mistérios. Mas em Platão, Santo Agostinho, Santo Tomás de Aquino, Descartes, Spinoza e Leibiniz, há uma fusão íntima de religião e raciocínio, de aspiração moral a par de admiração lógica pelo que é eterno, que vem de Pitágoras, e distingue a teologia intelectualizada da Europa do misticismo mais direto da Ásia. (...) aquilo que nos parece platonismo é, quando analisado, essencialmente pitagorismo. Toda a concepção do mundo eterno, revelada ao intelecto, mas não aos sentidos, deriva dele. Se não fosse por ele, os cristãos não teriam considerado cristo como sendo o Verbo; se não fosse por ele, os teólogos não teriam procurado provas lógicas da existência de Deus e da imortalidade. (Russel, 1957, p. 44)

Nos ensaios antropofágicos, o orfismo grego também figura de forma vaga entre os cultos e mitos pagãos orientais. Ao que tudo indica, Oswald buscou uma metáfora para a ancestral presença do místico e do sobrenatural na vida humana, a contrapelo da raiz metafísica comum à religião e à filosofia na tradição ocidental. Nesse sentido, é interessante notar que o "sentimento órfico" alude a um culto arcaico, ligado à figura de um poeta-cantor (e não a de filósofos ou sacerdotes) e que, de resto, é anterior à ideia da superioridade do intelecto sobre as sensações no entendimento dos mistérios religiosos ${ }^{42}$.

Essa dedução fica mais plausível se a associarmos a uma passagem do livro Dentes do Dragão. Trata-se de uma entrevista concedida a Milton Carneiro,

\footnotetext{
${ }^{42}$ Orfismo também foi o nome com o qual Guillaume Apollinaire batizou o movimento de pintores cubistas dissidentes que se contrapunham aos critérios excessivamente intelectuais do inicio do movimento e acrescentavam uma dose de lirismo e colorido aos seus quadros. Destacam-se, entre eles, Legér e Picabia. A ideia de sentimento órfico, então, pode ter sido um dado levantado ainda no período modernista e recuperado na etapa filosófica da antropofagia. De qualquer modo, esta acepção mais estética do termo também parece reforçar a aproximação mística entre espiritualidade e irracionalismo. (www.moma.org/collection/theme.php?theme_id=10142)
} 
na qual Oswald lhe explica na forma de pilhéria as origens da metafísica. Diz ele que o homem primitivo:

- "não era e não podia ser, mesmo que quisesse criatura metafísica"

Ao que retruca Carneiro:

- "porque não podia ser metafísico?"

-"porque não sabia gramática" diz Oswald

- "Que tem que ver gramática com isso?"

-"Tem tudo. A gramática é que ensina a conjugar o verbo ser e a metafísica nasce daí, de uma profunda conjugação desse verbinho. Não se sabendo gramática..." (DD, 1990, p. 182).

Desse ponto de vista, o sentimento órfico parece ser mais uma espécie de atavismo ligado a nossas convicções e anseios, do que qualquer outra coisa. Oswald argumenta, porém, que o fato de o orfismo ser uma constante humana não prova nada a favor de um culto ou de outro, pois sua expressão é sempre circunstancial. Logo, "o que prevalece tanto aqui como na Índia ou no Sudão ou em Londres é o órfico local”. (OC, 1991, p. 288).

Além disso, ao mesmo tempo em que sua manifestação varia de civilização para civilização, ela também se apresenta carregada das marcas idiossincráticas de cada um: "O homem flutua e flutuará sempre enquanto for homem, nas dobras da dúvida, no mistério da fé e no imperativo da descrença, no abismo órfico que o acompanha do berço ao túmulo" (AM, 1972, p.208). Com isso, ainda podemos acrescentar que o campo de ação do sentimento órfico não pode ser demarcado segundo a tradicional separação entre os aspectos "internos" e "externos" da experiência subjetiva.

Como se pode observar, a tentativa de uma definição precisa do orfismo antropofágico nos leva a uma noção obscura e relativista, que no final das contas não diz muita coisa sobre nada. De certa forma, é exatamente este o estatuto do conceito, já que ele diz respeito ao ilógico. Lembremos que, antes de tudo, para a antropofagia a "vida é devoração". No entanto, Oswald não para por ai.

Em 1944, em um dos primeiros ensaios que marcam seu retorno à antropofagia, Oswald simula uma entrevista consigo mesmo, na qual faz algumas breves análises de diferentes ciclos históricos, argumentando, por fim, que tanto as eras de tendência individualista quanto as de inclinação coletivista trazem em si 
a sua própria subversão. Contudo, diante do labirinto de fatos ambivalentes que ele próprio enumera para demonstrar sua teoria, acaba se vendo desafiado a desatar o nó de contradições do seu próprio esquema. Assim, em determinado momento, ele se pergunta retoricamente: "E isso não tem fim?":

Se fosse um antropófago transcendental, eu diria que não. A vida na terra produzida pela desagregação do sistema solar, só teria um sentido - a devoração. Mas se bem que eu dê à Antropofagia os foros de autêntica Weltanschauung, creio que só um espírito reacionário e obtuso poderia tirar partido disso para justificar a devoração pela devoração (...). Não. É preciso parar nas análises históricas de cada ciclo. É preciso ver como têm razão os que acreditam no progresso humano (...) (MT, 1972, p.28)

Esse trecho anuncia uma marcante idiossincrasia teórica dos ensaios antropofágicos. A saber, a convivência entre uma concepção trágica da vida e a crença no progresso histórico. Vimos no capítulo anterior que a reinterpretação oswaldiana da história da civilização revela influências de Nietzsche e Marx, numa peculiar tensão entre a genealogia do primeiro e a dialética do segundo.

É com base nessa paradoxal "genealogia dialética" que Oswald irá constatar que aquela massa bruta de sentimentos órficos originais se orientou, ao longo dos tempos, para dois sentidos antagônicos:

Enquanto na sua escala axiológica fundamental, o homem do Ocidente elevou as categorias do seu conhecimento até Deus, supremo bem, o primitivo instituiu sua escala de valores até Deus, supremo mal. Há nisso uma radical oposição de conceitos que dá uma radical oposição de conduta (CFM, 1972, p. 78).

Para Oswald, o ponto de partida comum a qualquer sistema de pensamento, primitivo ou civilizado, é a inevitabilidade da morte. A diferença é que, de um lado, o civilizado propôs uma cosmogonia messiânica que almejava a transcendência dos perigos do mundo por meio das promessas salvacionistas; do outro, o primitivo insistiu na imanência do perigo, projetando-a no ritual antropofágico que, justamente, não o deixava esquecer que a vida é devoração.

A partir daí, a antropofagia filosófica reconhece duas tendências psicossociais opostas presidindo a história da humanidade: o matriarcado, que 
resume o sistema mítico da vida primitiva e o patriarcado, que sintetiza as estruturas sócio-históricas da civilização. À primeira associa-se uma cultura antropofágica; à segunda uma cultura messiânica.

$\mathrm{Na}$ condição de testemunha ativa das convulsões da primeira metade do século $\mathrm{XX}$, Oswald acreditava piamente que a civilização ocidental vivenciava uma reviravolta material e espiritual. Por isso, na tese A crise da filosofia messiânica analisa o suposto declínio da hegemonia patriarcal, ao passo que no ensaio A marcha das utopias interpreta a história do ideário matriarcal e de seus movimentos de resistência no Ocidente. Ambos os textos profetizam o renascimento de um novo matriarcado.

Oswald não se via isolado nessa empresa intelectual. Para ele a filosofia existencialista, em voga na época, era apenas um sintoma da decadência da metafísica salvacionista e de seus "disfarces seculares". A antropofagia, por sua vez, era a chave que a mentalidade platônica europeia não conseguia encontrar.

A angústia de Kierkegaard, o "cuidado" de Heidegger, o sentimento do "naufrágio", tanto em Mallarmé como em Karl Jaspers, o Nada de Sartre, não são senão sinais de que volta a Filosofia ao medo ancestral ante a vida que é devoração. Trata-se de uma concepção matriarcal do mundo sem Deus. (AHC, 1972, p.144).

\section{2. \\ O matriarcado}

A tese do matriarcado antropofágico parte de um axioma: "a promiscuidade originária é um fato.” (CFM, 1972, p. 86).

Segue-se, daí, uma argumentação em cadeia: a monogamia deve ter sido o resultado de um estágio psíquico e social avançado da humanidade. Pode-se imaginar, igualmente, que nas primeiras sociedades não existia associação entre a gravidez e o ato sexual, sendo a geração provavelmente entendida como resultado de causas mágicas ou misteriosas ${ }^{43}$. Sem a figura do pai, o parentesco só podia

\footnotetext{
${ }^{43}$ Esta ideia, inclusive, encontra apoio parcial no testemunho de Malinowski em seus estudos com tribos da Melanésia, dos quais Oswald dizia estar a par, como menciona em algumas passagens
} 
subsistir pela consanguinidade materna. O filho, por sua vez, não era de um homem só, mas da tribo. Consequentemente, antes da invenção do casamento e da patrilinearidade, que regime haveria senão o do matriarcado poligâmico?

Foi Johann Jakob Bachofen quem realizou o primeiro estudo erudito sobre a hipótese do matriarcado. O livro Das Mutterecht de 1861, embora não tenha experimentado grande êxito na época em que foi publicado, posteriormente influenciou alguns estudos clássicos sobre as sociedades arcaicas, como Ancient Society de Lewis Morgan e A Origem da Família, da propriedade privada e do Estado de Friedrich Engels.

Bachofen produziu um complexo trabalho de erudição sobre as civilizações arcaicas, com base em diversos textos da Antiguidade (Homero, Heródoto, Ésquilo, Platão, Estrabão, entre outros) nos quais afirma encontrar vestígios de uma época de primazia do "direito materno". Trata-se de uma dimensão cultural reprimida que, eventualmente, irrompe em mitos, relatos e testemunhos históricos sobre povos arcaicos, trazendo valores opostos aos predominantes na civilização helênica:

(...) Son un componente esencial de aquella cultura originaria cuya fisionomía peculiar está íntimamente relacionada con el predominio de lo materno (...). Los locrios nos llevan hasta los léleges, y a éstos se unen los carios, etolios, pelasgos, caucones, arcadios, epeos, minios, telebeos...; y en todos ellos aparece el matriarcado, y la civilización baseada en él se distingue en una enorme variedad de rasgos particulares. (Bachofen, 2008, p.29)

Em linhas gerais, ele propõe a ideia de que houve um período de poligamia e de grande prestígio das mulheres diante da ideia de que eram a fonte exclusiva das gerações futuras. Segundo Bachofen, depois de dois momentos primordiais de barbarismo masculino (Heitarismo) e de reação guerreira feminina (Amazonismo), sucedeu um período pacífico calcado no predomínio de princípios tidos como femininos nas mitologias antigas (a terra, a maternidade, a religiosidade, a afetividade). Este sistema foi denominado de Ginecocracia. Do

(VM, 1972, p. 204; OA, 1991, p. 243, 244). De acordo com Malinowski, nessas tribos prevalecia o tipo de parentesco matrilinear em que a associação sexo-concepção não existia. "Segundo a crença dos nativos as crianças são inseridas no útero materno como minúsculos espíritos, geralmente pela ação do espírito de uma parenta morta da mãe (...)" (MALINOWSKI, 1973, p.23). Nessas tribos, porém, a figura do pai existia, e era exercida pelo irmão da mãe. 
ponto de vista sexual e jurídico, vigorava uma organização social em tudo estranha à ordem baseada no domínio do paterfamílias, que para Bachofen só é definitivamente consolidado com o direito romano.

Walter Benjamin compreende a tese como um "ideal do direito". Ele explica que a hipótese de que aquelas comunidades matriarcais desenvolveram um alto senso de igualitarismo social fazia Bachofen supor que o comunismo era inseparável da Ginecocracia. Para o antropólogo suíço, os resquícios daquela fase ancestral pareciam especialmente visíveis na análise dos cultos de Dionísio, que considerava um princípio feminino: "A religião dionisíaca é a confissão da democracia, porque a natureza sensual a que ela se dirige é patrimônio de toda a humanidade e não reconhece nenhuma das diferenças estabelecidas pela ordem cívica ou a hierarquia espiritual” (Bachofen apud Benjamin, 2009, p. 91).

O matriarcado antropofágico evoca de forma similar esse arquétipo dos rituais dionisíacos, comunistas e libertários, recalcado pela ascendência do patriarcado. Oswald chega a especular sobre um parentesco longínquo entre os aspectos matriarcais do carnaval brasileiro e os cultos orgíacos gregos, segundo uma suposta origem comum na "marcha da cultura órfica da África, via Creta, para a Grécia precedente aos séculos homéricos. Não seria da mesma origem mística, plástica e melódica que trouxeram para o Brasil, os escravos da África Oriental, os assombros populares da Praça Onze?", pergunta Oswald. (DA, 1972, p. 221-222)

Talvez por isso seja comum a associação entre a antropofagia e a acepção nietzscheana do dionisíaco, embora, na verdade, Oswald tenha afirmado que Bachofen fora "vulgarizado por Nietzsche" (CFM, 1972, p.88). O que, geralmente, foge a essas aproximações é o excêntrico cruzamento que Oswald faz entre as ideias nietzscheanas e algumas concepções igualitaristas e utópicas que, provavelmente, arrepiariam o bigode de Nietzsche como reflexo da mais pura retórica de rebanho ${ }^{44}$.

\footnotetext{
${ }^{44}$ Por outro lado, não se pode ocultar que, para alguns comentaristas, a interpretação bachofeana dos cultos dionisíacos, longe de ter sido "vulgarizada", foi, na verdade, confirmada por Nietzsche. Ou seja, existiria um certo entusiasmo pelo fundo coletivista dos cultos dionisíacos, também em Nietzsche. Rosa Dias, por exemplo, destaca a influência de Bachofen na elaboração do conceito de dionisíaco-apolíneo nietzscheano. De fato, o jovem Nietzsche foi um frequentador assíduo da casa de Bachofen durante o ano de 1871, quando lecionava na Basileia. A autora assinala trechos das
} 
De qualquer forma, a influência do escritor alemão sobre os ensaios antropofágicos é categórica. Apenas, como argumentei, creio ser mais decisiva na forma com que Oswald entrelaça os cenários históricos a reflexões morais e psicológicas, do que propriamente na aplicação conceitual do pensamento de Nietzsche.

Em estilo genealógico, Oswald procura desvelar a série de pendências subjetivas e sociais que dormitam sob as estruturas do patriarcado (e, portanto, sob o desenvolvimento do Estado e do que se entende por história civilizada). Como é de se esperar, a civilização patriarcal é responsabilizada pelo aviltamento das relações sociais nos âmbitos da economia, do direito, da sexualidade e dai por diante.

Assim sucede na defesa oswaldiana do "direito natural" contra o "direito positivo". Para ele, "com Hans Kelsen vemos imediatamente que a ideia de justiça, em todas as sociedades humanas, aparece como 'natural'. É coisa natural o direito justo. E sendo justo passa a ser legal" (CFM, 1972, p. 80).

Kelsen foi um eminente jurista e filósofo, autor de um paradigmático estudo sobre as diferenças entre o direito natural (idealista) e o direito positivo (realista). Suas conclusões, entretanto, são veementemente críticas ao primeiro (também chamado de jusnaturalismo). Oswald, por sua vez, defende a noção idealista que, grosso modo, postula a ideia de que um direito só pode ser considerado válido se sua prescrição corresponder às exigências prévias da justiça: "Quer isto dizer que a validade da norma da justiça é o fundamento da validade do direito positivo." (Kelsen, 2001 p.99).

Para o positivismo jurídico, contudo, a validade do direito independe da sua correspondência à norma de justiça. Ou seja, um direito pode valer mesmo

conferências preparatórias para $O$ nascimento da tragédia, a partir dos quais conclui: “Dionísio é apresentado como o deus da embriaguez e da desmesura, é visto como aquele que rompe todas as barreiras em busca de uma "harmonia do mundo". Todas as delimitações de castas que a necessidade e a arbitrariedade estabeleceram entre os seres humanos desaparecem: "o escravo é um homem livre, o nobre e o humilde se unem para formar os mesmos coros báquicos ". Não é mesmo a ideia de Bachofen que está presente nessa composição do dionisíaco de Nietzsche?" (DIAS, 2004, p.223). Interpretações como esta trazem consistência e coerência ao alinhamento entre o dionisíaco nietzscheano e a antropofagia. Pessoalmente, no entanto, creio que tal olhar, mesmo quando reduzido às ideias do jovem Nietzsche, tende a amenizar sua explícita filosofia do poder, que se quis acessível a poucos, e que defendeu a expressão radicalmente singular da potência individual, e não aquela espécie de harmonia mística com o todo à qual parece se referir Bachofen ao comentar as origens matriarcais dos ritos dionisíacos. 
que seja injusto. Isto não significa que a teoria afirme que não existe qualquer justiça; significa que os homens propõem muitas normas de justiça diferentes e contraditórias entre si e, portanto, que não existe um valor absoluto e transcendente de justiça.

Ainda segundo Kelsen, embora a teoria do direito natural seja uma doutrina idealista, ela não é "A doutrina jurídica idealista. Distingue-se das doutrinas jurídicas idealistas-dualistas pelo facto de - como seu nome indica considerar a 'natureza' como a fonte da qual promanam as normas do direito ideal, do direito justo" (Kelsen, 2001, p. 102). Isto é, o jusnaturalismo deduz a justiça como uma emanação da suposta natureza do homem, observável nas suas inclinações, instintos e pulsões.

Não é preciso grande esforço para constatar as ingenuidades e brechas de tal teoria. Para além do fato de que ignora a atividade conflitante dos "impulsos" (que tendem igualmente para o bem como para o mal, para a passividade como para a agressão, para a justiça como para a injustiça), também negligencia o problema do relativismo dos valores em discussão (quer dizer, bem e mal, justo e injusto, variam de acordo com a cultura, época e com o ponto de vista dos diferentes indivíduos desses contextos). Por último, não bastasse o caráter contingente dos impulsos e valores, existe ainda um problema lógico, pois, se admitirmos que as pulsões do homem são sua natureza, e que de sua existência deve-se elaborar uma norma de conduta, tal norma já nasce supérflua. "Com efeito, os homens conduzem-se de fato tal como são determinados pelas suas pulsões; e é um contrassenso prescrever aos homens que se conduzam tal como eles efetivamente se conduzem." (Kelsen, 2001, p. 109).

A bem da verdade, o "direito antropofágico ${ }^{45 "}$ é pouco desenvolvido nos ensaios de 1944-54, diferentemente do que ocorreu na época da Revista de Antropofagia (entre 1928-29), quando foi tema frequente. Naquela conjuntura, as discussões giravam em torno da noção de "posse contra a propriedade" que, resumidamente, defendia que a propriedade, originalmente, nada mais era do que

\footnotetext{
45 Acerca do tema do "direito antropofágico" alguns ensaios aprofundam o debate, como "Oswald de Andrade, a luta da posse contra a propriedade" de Maria Eugênia Boaventura. (BOAVENTURA, 1983), e mais recentemente, "A única lei do mundo" de Alexandre Nodari. (NODARI, 2010),
} 
uma apropriação pura e simples. O direito privado, por sua vez, teria sido elaborado para garantir essa posse. A "posse contra a propriedade", portanto, joga com a ideia de que só pode existir roubo depois de inventada a "ficção" do direito a propriedade. É nesse sentido que Oswald ironicamente afirmou que: "O Brasil é o maior grilo da história - um grilo de milhões de quilômetros talhados no título morto, de Tordesilhas" (DD, 1990, p.54).

$\mathrm{Na}$ antropofagia ensaística, no entanto, o tema é retomado de forma mais genérica, dentro do contexto da crítica aos fundamentos messiânicos do patriarcado. Nesse sentido, a apologia do "direito natural" tem como finalidade sublinhar as ligações entre a arbitrariedade dissimulada do direito positivo e a arbitrariedade divina no discurso messiânico. Ou seja, ao exaltar o jusnaturalismo, Oswald queria apontar para a origem comum do direito positivo e do messianismo na exacerbação do domínio político pelas elites patriarcais.

Como consequência, para além da tradicional crítica proudhondiana à propriedade privada como injusta usurpação garantida pelo Estado, Oswald pretende acentuar a fraude patriarcal, que teria deformado um suposto sentido original de justiça com a ideia de um desígnio divino. Segundo seu raciocínio, no momento em que a sociedade se dividiu e passou a ser dirigida por uma classe à parte, emergiu então o chamado direito positivo, que transformou em legal os interesses daquela classe dirigente:

Sendo aquele um direito legislado exigia obediência. Estabeleceu-se então a organização coercitiva que é o Estado, personificação do legal.

Da validade do legal como legal, foi possível a transferência para o domínio do arbítrio de toda emanação de Direito.

Passou a ser Direito aquilo que negava pela coação a própria natureza do homem. No longo desenvolvimento desse direito que deu as leis do Patriarcado, o jusnaturalismo sempre reivindicou o seu papel de fonte natural e direta de justiça. (CFM, 1972, p. 80)

O debate sobre a justiça nos ensaios parece aproximar Oswald da concepção "rosseauniana" de "estado de natureza" em detrimento da "hobesiana". ${ }^{46}$ Não se pode negar que, a despeito da propagada imagem do

\footnotetext{
${ }^{46}$ Para alguns comentadores esta é uma das contradições de base típicas da antropofagia. Evando Nascimento, por exemplo, acredita que: "Oswald faz uma combinação de dois mitos
} 
antropófago bárbaro e vingador, os ensaios resvalam frequentemente para o sonho da "idade de ouro", na qual o homem natural, sem os recalques sexuais e a escravidão, viveu e viverá em harmonia e plenitude lúdica.

Não obstante, existe um ingrediente cético na composição deste "homem natural", que, no final das contas, é uma afronta à soberba da moralidade cristãbranca-europeia $^{47}$. Assim, por essencialista que possa parecer essa apologia à conduta natural, para Oswald tratava-se de demarcar uma visão de mundo mais "realista", que conduzisse a uma postura estoica diante do enigma da existência.

Tendi e tendo cada vez mais para uma filosofia que chamo de filosofia da devoração. A vida é devoração pura e só há uma conduta a seguir: o estoicismo. É verdade que outro conceito da existência divide a humanidade. É o conceito messiânico e salvacionista. Os que se enfileiram debaixo dessa bandeira são os que acreditam que há qualquer coisa a salvar dentro deste mundo ou fora dele. $\mathrm{O}$ primeiro pensamento é que presidiu a vida das sociedades primitivas tão superiores às sociedades civilizadas. Estas servem-se do messianismo para criar as servidões do corpo e do espirito e as ilusões de toda a espécie. (DD, 1991, p. 227)

Percebe-se como, muitas vezes, o idealismo que transparece nos ensaios é resultado do esforço para denunciar a puerilidade das epistemes que presidiram o curso da civilização ocidental. Não é raro, portanto, que a crítica ao caráter ilusório da metafísica messiânica, seja acompanhada de afirmações essencialistas e românticas sobre a natureza humana no matriarcado.

Em outros momentos, porém, Oswald demonstra estar consciente dessa contradição, mas se defende apelando para o prestígio que gozava o conceito de utopia na época. Autores contemporâneos, como Ernst Bloch ${ }^{48}$ e Karl Mannheim,

contraditórios: o antropófago, por ser um devorador, tem muito da natureza lupina do homem descrito por Hobbes, e ao mesmo tempo, guarda características da bondade natural do bom selvagem rousseauniano. Mau porque devora o outro e bom porque o faz para afirmar sua própria constituição tribal, ou melhor, nacional.” (NASCIMENTO, 2011, p. 342).

${ }^{47}$ Nas entrevistas o romantismo de Oswald, frequentemente, era substituído por uma postura mais sarcástica. Numa dessas ocasiões em que explicava o caráter simbólico da antropofagia e que, portanto, não estava defendendo "um retorno à tanga", ele cita Bernard Shaw, que teria dito que "“Está mais próximo do homem natural quem come caviar com gosto do que quem se abstém do álcool por princípio’. É isso!” (ANDRADE apud FONSECA, 1990, p. 254).

48 Associando as ideias de utopia e revolução, Ernst Bloch, por exemplo, afirmava que o marxismo, sobretudo, inventou um conceito de saber que não tem mais como referência o que foi ou existiu, mas a tendência do que é ascendente, introduzindo o futuro na abordagem teórica e prática da realidade. $(\mathrm{BLOCH}, 2006)$. 
buscaram relacionar o termo à práxis política desvinculando-o da sua habitual aura contemplativa idealista. De forma semelhante, Oswald afirmava que: "as Utopias, no seu desenvolvimento intelectual e histórico, ganharam terreno e aproximaram-se das soluções da realidade. A experiência viva de suas consequências fá-las vigentes no século" (DA, 1972, p. 224).

Não podemos esquecer que estamos em meados do século XX, na infância da Guerra-fria. Atualmente, soa estranho aos nossos ouvidos descrentes a convicção nas qualidades do homem e nas utopias de reconstrução do mundo. Naquela época, contudo, o cenário de devastação pós-guerra abria as janelas de um futuro ainda incerto: "Nada se parece mais com uma casa em ruínas que uma casa em construção", dizia Cocteau. (Cocteau apud Andrade, DD, 1990, p.125).

Interessava abertamente à antropofagia vasculhar o que havia de sonho na realidade e o que havia de realidade no sonho. O que ela pleiteava com as hipotéticas descrições da justiça pré-divisão de classes era, mais do que qualquer coisa, a oposição frontal entre uma "cultura da escravidão" e uma "cultura da liberdade".

Assim, voltando à narrativa antropofágica, foram certas circunstâncias de clima e de técnica que possibilitaram o estabelecimento dos povos fixos, e foi na evolução destes que surgiu a monogamia, o matrimônio, a herança e a propriedade privada da terra. Porém, antes disso, as promíscuas tribos matriarcais viviam nômades e sem regularidade de produção. "Seu direito era o direito da guerra, a moral, a da liberdade, e a economia, a economia do ser" (OA, 1991, p. 242).

Para Oswald era razoável pensar que, assim como antes do casamento houve a poligamia, antes da servidão e da moeda houve o serviço prestado e o benefício retribuído. Irrompe aí uma nova dualidade, desta vez econômica: a "economia do ser" x a "economia do haver". A primeira se caracteriza pela propriedade coletiva do solo e pelo sistema de trocas; a segunda, pela posse privada da terra e do escravo, pela divisão do trabalho e mais tarde pelo dinheiro.

Embora haja afinidades entre a "economia do ser" e o matriarcado poligâmico, e entre a "economia do haver" e o patriarcado monogâmico, existem nuances nessa relação. Da mesma forma que o advento da monogamia "não privou que a maior parte da humanidade continuasse a procriar sem a legitimidade 
ritual das convenções genealógicas" (AO, 1991, p. 243); em certos períodos já avançados da civilização, como o período feudal, prevaleceu uma "economia do ser": "que é a vassalagem senão uma troca de serviços sem a intervenção do dinheiro?" (OA, 1991, p. 245).

Ainda que a história ocidental, basicamente, só nos forneça exemplos de culturas em que liberdade e escravidão se engendram, Oswald segue especulando sobre os traços psicossociais do hipotético sistema jurídico, econômico e familiar matriarcal. Nesse espírito, argumenta que, apesar da revolução empreendida pela psicanálise, ela "custou a compreender que era preciso atacar o Superego paternalista" (CFM, 1972, p. 123). Ele lamenta que Freud não tenha dado atenção suficiente ao caráter de "revolução" do patriarcado ${ }^{49}$, fixando essa etapa histórica como a verdadeira origem de toda a organização social.

Parecia-lhe, entretanto, que àquela altura, em 1950, esse cenário estava mudando. Passava-se a uma fase da psicanálise em que se procurava "legalizar o homem natural que resistia, por meio de neuroses e estados de ficção, às injunções seculares do socratismo ocidental" (CFM, 1972, p.124). Oswald, então, reclama que se credite à história do patriarcado, o seu devido papel na moldura subjetiva do homem e da mulher civilizados. Destaco abaixo dois exemplos de como isso ocorre:

\begin{abstract}
Que é a crônica do Monaquismo oriental como ocidental, desde a ascese brâmane até o anacoretismo autoflagelador, ou os fartos refúgios do ócio que vieram a ser os conventos, que é a vida solipsista claustral e celibatária, senão um código de fenômenos de defesa nas abominações do Patriarcado? (CFM, 1972, p. 124)
\end{abstract}

Ou ainda:

\footnotetext{
${ }^{49}$ A respeito disso, Oswald comenta: "Simone de Beauvoir, no Deuxième Sexe, esse evangelho feminista que se coloca no pórtico da nova era matriarcal, escreveu: "Ce n'est pás La libido féminine qui divinise le père". É na luta doméstica com a mãe e depois na luta com o ambiente, que cresce a divinização possível do pai como socorro, poder moderador e alento sentimental. Fenômeno do Patriarcado. No estudo dedicado à Psicanálise, a grande escritora cita Freud perplexo no seu estudo sobre Moisés, ante a soberania do pai na História do Homem. Evidentemente, o criador da Psicanálise não deu atenção especial à Revolução do Patriarcado." (CFM, 1972, p. 126)
} 
A importância catastrófica atribuída a Don Juan, numa tribo poligâmica seria ridícula. Don Juan é uma criação do Patriarcado. Um forte organismo de agressão nos domínios do pecado contra a herança e a legitimidade. Todas as suas vítimas do período econômico-moral da Renascença e do Romantismo seriam hoje, na América, vulgares divorciadas, usando, é claro, métodos anticoncepcionais e solidões de arranha-céu (CFM, 1972, p.125)

Para que tenhamos uma dimensão de quais poderiam ter sido as possíveis patologias psíquicas em uma sociedade matriarcal, seria necessário primeiro descartar a importância de certas descrições do "psiquismo patriarcal". Por exemplo, numa horda matriarcal a tendência é a de que fenômenos constituintes como o complexo de Édipo e o complexo de castração não fizessem sentido. Inversamente, podemos imaginar que no matriarcado, afora a inexistência da monogamia, a figura do pai se substitui pela da sociedade (tribo, comunidade, etc). Consequentemente, "desaparece a hostilidade contra o pai individual que trás em si a marca natural do arbítrio. No matriarcado é o senso do Superego tribal que se instala na formação da adolescência” (CFM, 1972, p.125).

Com isso, o inconsciente remontaria a outras origens, abrindo-se para um jogo simbólico mais amplo do que o do trauma sexual:

O documental índio (o sonho augural e estratégico em Amorim, Barbosa Rodrigues, Couto Magalhães, Macunaíma) é mais do que tudo o desenvolvimento de um estado de luta que a memória desperta. Nada tem com o sonho em função do "pecado sexual" que coloca Freud nos quadros do catolicismo (DD, 1991, p. 52)

Em resumo, do prisma genealógico dos ensaios antropofágicos, o conceito de matriarcado explora o fato de que, no fundo, a tradição ocidental simplesmente não leva a sério a possibilidade de ter havido, em sua gênese, qualquer organização social e familiar estranha à jurisdição do paterfamílias romana, e que, portanto, concebe o nosso mundo começando com a unidade de servidão, culto e direito fornecidos pelo modelo romano do "Pater est quaem nuptiae domstrant" (CFM, 1972, p.89).

Oswald dá os devidos créditos da teoria do matriarcado a Bachofen, dedicando atenção especial a sua interpretação da Orestéia de Ésquilo. Segundo o antropólogo suíço, esta tragédia registra o período de declínio moral do 
matriarcado e da revolução do direito paterno na Grécia antiga. Principalmente no que se refere à terceira e última parte (Eumênides) em que se passa o julgamento do matricida Orestes.

Logo após matar a mãe (Clitemnestra) e seu amante (Egisto) em vingança pelo assassinato de seu pai (Agamêmnon), Orestes é perseguido pelas terríveis Erínias (deusas da vingança, protetoras do direito materno), mas antes que seja pego, é protegido por Apolo que as adormece e encaminha Oreste ao templo de Palas Atena (no latim, Minerva, deusa da justiça) que resolve submetê-lo ao Areópago - o tribunal do Júri ateniense. Após um empate nos sufrágios, Atena decide votar pela salvação de Orestes (daí deriva o "voto de Minerva"), passando por cima de uma das leis mais severas que era aquela que ia contra o assassinato entre consanguíneos, principalmente ao matricídio.

A princípio, as Erínias se revoltam com aquela decisão que, deliberadamente, abandona as antigas prerrogativas, arrancando-lhes o poder da vingança. Mas, a conselho de Atena, acabam aceitando os fundamentos do novo estatuto político e se tornam Eumênides, isto é, "benfazejas". "Os 'deuses da jovem geração', como os chamam as próprias Erínias, são mais poderosos que elas, e só lhes resta resignarem-se" (Engels, 1980, p.9). Com isso, sentencia Oswald: "Estava aí assinalada a revolução que, na Grécia, destronava a mãe de seu poderio incontestável. De ora em diante, seria aceito na Hélade o direito paterno e suas consequências" (VM, 1972, p. 203).

Bachofen explica sua teoria com base no argumento de que os mitos que narram a relação entre as potências masculinas e femininas das manifestações cósmicas (reproduzidas nos inúmeros deuses e deusas) não são um paralelismo sem fundamento, mas símbolos de um pensamento da história.

Las tradiciones míticas se presentan como la expresión fiel de la ley vital de aquellos tiempos en los que se pusieron las bases del desarrollo histórico del mundo antiguo; aparecen también como la manifestación de la mentalidad originaria, como revelación histórica inmediata, y por consiguiente como fuente histórica de la mayor autenticidad. (Bachofen, 2008, p.31)

É pela análise simbólica do legado mítico grego e pelos costumes revelados ali que Bachofen justifica sua conclusão de que, no princípio, houve o 
matriarcado. Engels, no entanto, pensava que apesar do pioneirismo de Bachofen (já que "antes dele toda história da família ainda se achava sob a influência dos Cinco Livros de Moisés"): “aquele estado social primitivo, admitindo-se que tenha realmente existido, pertence a uma época tão remota que não podemos encontrar provas diretas de sua existência, nem mesmo entre os fósseis sociais, nos selvagens mais atrasados" (Engels, 1980, p. 32). Para ele, Bachofen não passava de um "místico genial" e a teoria do matriarcado uma teoria calcada em "alguns fatos e muitas hipóteses" (Ibidem).

Sem dúvida, ainda hoje não há consenso sobre o que é real e o que é fantasia nas teorias do matriarcado. Embora tenham sido descobertas tribos matrilineares nos rincões do mundo, é sabido que elas não preenchiam todos os quesitos imaginados pela antropologia clássica e pelos estudos de mitologia e religião comparada do século XIX (Frazer, Bachofen, Morgan).

Um dos estudos etnológicos mais famosos em torno do tema foi realizado por Malinowski, na tribo dos Trobriand da Melanésia. No livro Sexo e repressão na sociedade selvagem ele compara a teoria psicanalítica com a regulação da sexualidade naquelas tribos matriarcais da Nova Guiné. Como se pode prever, proliferam diferenças nas condutas e nos tabus sexuais. Curiosamente, porém, ao comparar as formações repressivas daquelas sociedades com a ocidental, o antropólogo deixa claro que as maiores dissimetrias não se prendem a matrilinearidade em si, que além de monogâmica tem base na herança e na propriedade privada. Ocorre que, entre outras coisas, Malinowski observa não haver uma condenação do sexo ou da sensualidade como tal, principalmente "não se conhece o horror moral à ideia da sexualidade infantil" (Malinowski, 1973, p. 72).

Após examinar detalhadamente vários tópicos correlatos à vida sexual dos Trobriand e a de "nossa civilização", Malinowski chega à seguinte conclusão:

A maior parte das teorias da matrilinearidade tem por fim associar esta instituição com a primitiva existência da promiscuidade, com a resultante incerteza da paternidade e assim com a necessidade de estabelecer o parentesco através das mulheres (...). A maioria das teorias implicam o direito paterno e o direito materno como alternativas mutuamente exclusivas. (...) Entretanto o curso lógico da pesquisa sugere que deveríamos perguntar em primeiro lugar se existe a matrilinearidade independente da contagem paterna e se talvez os dois tipos de 
contagem da descendência não são complementares um do outro em vez de serem antitéticos. (Malinowski, 1973, p. 215-216)

É evidente que se déssemos continuidade à sugestão de Malinowski, fatalmente negaríamos os postulados do matriarcado antropofágico ${ }^{50}$. $\mathrm{Na}$ realidade, nas poucas vezes em que descreve a índole matriarcal dos índios brasileiros, Oswald recorre às narrativas de Américo Vespúcio e aos missionários inacianos, e não às pesquisas de Levi Strauss. Não surpreende, dessa forma, o desalinhamento conceitual entre o seu matriarcado e o de Malinowski (ou mesmo da antropologia em geral).

O que ocorre é que a antropofagia filosófica não privilegia a normatividade de qualquer doutrina, seja ela a historiografia, a psicanálise, a etnologia, a sociologia, etc., mas sim o espaço narrativo-conceitual em que esses (e outros) domínios teóricos se fundem na ensaística literária. As conjecturas oswaldianas variam entre o exercício crítico e a pura profissão de fé. Por isso se inclinam tão facilmente para a subversão dos saberes com as quais dialoga, isto é, porque tencionam, justamente, interferir nas explicações canônicas sobre origem, função e necessidade das nossas instituições.

Creio que a abordagem antropofágica do conceito de matriarcado só pode se esvaziar se for tomada ao pé da letra, como uma tentativa de descrição realista e neutra de fatos históricos e antropológicos. Até porque, os temas que norteiam o texto oswaldiano, tais como, a sexualidade, o poder, a liberdade, a sociedade, etc.; observados nos seus significados análogos em uma tribo matrilinear atual - e que dirá em tempos imemoriais e sem registro -, divergem de tal maneira dos nossos que, no limite, não nos restaria alternativa além de uma exaustiva pesquisa etnológica e filológica. Todavia, tal estudo não apenas guardaria pouquíssima afinidade com a antropofagia ensaística, como inevitavelmente nos levaria ao ingênuo diagnóstico de que as teses oswaldianas não são comprováveis.

No entanto, se consideramos a sua elaboração metafórica teremos diante de nós um quadro teórico completamente diferente, que visa muito mais ao

\footnotetext{
${ }^{50}$ Não obstante, veremos mais a frente que o anseio da antropofagia é, justamente, o de uma síntese entre o patriarcado e o matriarcado. O que faz com que, ironicamente, Oswald conceba no terreno do ensaísmo utópico aquilo que Malinowski (ao menos à priori) buscava definir pelo trabalho científico antropológico.
} 
recurso de insights para uma reflexão sobre nossos valores. Assim, quando Oswald defende uma "cultura antropofágica" contra uma "cultura messiânica" está mais do que claro que o faz de forma alegórica e provocativa. Ele obviamente não sonhava que nos comêssemos uns aos outros, mesmo que esse banquete fosse carregado de belos e purificadores sentidos rituais.

O mesmo se passa com os conceitos de matriarcado e de patriarcado. São ícones de uma dialética silenciosa, latente no homem e na história do Ocidente. Comentando o assunto, Gonzalo Aguillar enxerga uma estratégia semelhante já no próprio Bachofen:

(...) quando Bachofen fala da precedência do estado matriarcal sobre o patriarcal, não é possível entendê-lo num sentido meramente histórico, mas como a existência de algo que sucedeu no passado e atua no presente como recusado, reprimido, nos silêncios, nas frestas, ou mesmo convertido em detritus. Bachofen irá reunir estes traços e vestígios para armar com eles seu corpus materno. (Aguillar, 2010, p.60)

Oswald sabia que "só uma paleontologia social possibilitaria a restauração e o estudo das estruturas matriarcais desaparecidas" (CFM, 1972, p.89). Por isso afirmou que era "preciso criar uma Errática, uma ciência do vestígio errático, para se reconstruir essa vaga Idade de Ouro, onde fulge o tema central do Matriarcado" (CFM, 1972, p 88). Portanto, é na vigência de uma pesquisa errática ${ }^{51}$, na qual literatura, filosofia, mito, história, psicologia e etc. não se excluem que a antropofagia definirá que:

No mundo do homem primitivo que foi o Matriarcado, a sociedade não se dividia ainda em classes. O Matriarcado assentava-se sobre uma tríplice base: o filho de direito materno, a propriedade comum do solo, o Estado sem classes, ou seja, a ausência de Estado (CFM, 1972, p. 80).

\footnotetext{
${ }^{51}$ A definição de "ciência errática" em Oswald é desenvolvida com maestria por Gonzalo Aguillar no ensaio introdutório de seu livro: "Por una ciência del vestígio errático - ensayos sobre la antropofagia de Oswald de Andrade" (AGUILLAR, 2010)
} 


\section{3. \\ O patriarcado}

A queda do mundo matriarcal perdido na história teria ocorrido quando o homem deixou de devorar seu inimigo para escravizá-lo. Nesse momento tem início a irrefreável ascendência do patriarcado. Com a escravidão, desenvolve-se a técnica e a divisão do trabalho, que deságuam na hierarquização da sociedade em classes, ou, simplesmente, no Estado. O poder, consequentemente, se destaca da sociedade e passa a ser exercido à parte dela, por uma classe dirigente, que garante a obediência pela coerção.

O novo status quo, entretanto, só poderia sobreviver apoiado em um discurso religioso que o justificasse, já que "o sentimento órfico é uma dimensão do homem e exige tutelas irracionais" (OA, 1991, p.237). O fim da antiga era demandava novas crenças que dessem vazão às aspirações de uma nova sociedade.

Duas instituições formariam os pilares do patriarcado: o messianismo e a monogamia. A primeira elabora a retórica do Estado, justificando-o cosmologicamente e transferindo a fruição da vida para o além. A segunda garante a manutenção do poder pela herança, enquanto reforça as analogias entre as figuras de Deus, do rei e do pai. É assim que "a um mundo sem compromissos com Deus, sucede um mundo dependente de um Ser Supremo, distribuidor de recompensas e punições. Sem a ideia de uma vida futura, seria difícil ao homem suportar a sua condição de escravo" (CFM, 1972, p. 81).

Por outro lado, àquela "Idade do ócio" vivida no matriarcado, sobrepôs-se a sua negação: o (nec-otium) negócio ${ }^{52}$. Surge uma hierarquia do ócio, que distribui em escala decrescente, até o escravo, os encargos do trabalho. No topo da pirâmide, ditando as novas coordenadas patriarcais, desponta o sacerdote. Segundo Oswald, sacerdócio quer dizer "ócio consagrado aos deuses”. Sua vigília tinha a finalidade de pregar a obediência do escravo ao senhor da terra, que era representante do senhor do céu. O sacerdote se transformou no grande

\footnotetext{
52 Segundo Benedito Nunes: "partilha que Ortega y Gasset faz remontar à antiguidade" no livro "Meditações técnicas" (NUNES, 1972, p. XLIX).
} 
manipulador do sentimento órfico. Apropriou-se do discurso, seja para legislar sobre a paz, seja para ordenar a guerra. ${ }^{53}$

A figura abstrata do sacerdote velhaco envenenando as diversas culturas ao longo da história será fonte de recorrentes indignações nos ensaios. Ela remete principalmente à célebre representação de Nietzsche do personagem, mas também a crítica marxista da religião:

A importância do Marxismo consiste em ter desmascarado para sempre a economia do haver que substituíra a economia do ser, como advento do patriarcado, cujo fato central é a herança. O patriarcado, havia milênios, impusera suas leis tanto no Egito como na China, sempre apoiando-se na interesseira e espúria ação do sacerdócio. (...) À vista de uma disponibilidade órfica, surgem logo nuvens, evocadores de fantasmas e detentores das chaves miríficas do além. (OA, 1991, p. 248).

Se com Bachofen a antropofagia resgata vestígios do matriarcado nos mitos e tragédias gregas, com Werner Jaeger dá relevo às marcas da ascendência patriarcal na Paideia ${ }^{54}$ grega e nos poemas de Hesíodo. Assim, Os trabalhos e os Dias, como o "pecado original”, já introduzia um importante mito da teoria messiânica, que é a ligação entre a servidão e o céu, situando o "homem na condição de besta diante do Olimpo" (CFM, 1972, p.91). Ademais, se no Gênesis é Eva a responsável pela queda do homem, na Grécia homérica recai sobre Pandora a culpa de disseminar as mazelas que marcam a aventura humana sobre a terra. Concluindo: "Nas duas versões, na bíblica como na helênica, ambas patriarcais, a Idade de Ouro, que mais tarde Ovídio cantaria, refulge na saudade do homem reduzido a escravo pelo patriarcado" (CFM, 1972, p. 91).

\footnotetext{
${ }^{53}$ Oswald reconhece que a figura do sacerdote já estava presente no matriarcado. Inicialmente, porém, ele era um símbolo da coletividade. Como aponta James Frazer no livro O Ramo de Ouro, a primeira lenda de um sacerdote que se tem notícia, é a do sacerdote do Lago de Nemi, que rodava dia e noite em torno de uma árvore, guardando o seu posto "à espera do golpe fatal de seu sucessor que o espreitava". Essa seria a figura do sacerdote primitivo, de sentido coletivista, "cuja vigilância depende como a sua, a própria vida da tribo" (CFM, 1972, p.81).

${ }^{54}$ Paideia é a raiz etimológica da palavra pedagogia. Diz respeito ao modo como os gregos educavam um jovem para que viesse a se tornar um homem belo e justo, e depois, em Platão, um cidadão. Segundo Pierre Hadot: "Desde os tempos da Grécia homérica, a educação dos jovens fora a grande preocupação da classe dos nobres, daqueles que possuem a Arete, isto é, a excelência necessária pela nobreza de sangue, que se tornará, mais tarde com os filósofos, a virtude, isto é, a nobreza de alma" (HADOT, 1999, p. 31).
} 
Oswald ignora muitos detalhes da análise de Jaeger para relacionar a imagem de Hesíodo como "cantor do trabalho" à criação de um código da servidão. Ainda assim, a hipótese não é de todo absurda, pois, de fato, em alguns trechos, Jaeger fornece elementos para tal:

O trabalho e os sofrimentos devem ter aparecido algum dia no mundo. Não podem ter feito parte, desde a origem, da ordem divina e perfeita das coisas. Hesíodo assinala-lhes como causa a sinistra ação de Prometeu, o roubo do fogo divino que encara de ponto de vista moral. Como castigo, Zeus criou a primeira mulher, a astuta Pandora, mãe de todo gênero humano. Da caixa de Pandora saíram os demônios da doença, da velhice, e outros males mil que povoam a Terra e o mar. (Jaeger, 2001, p.95).

Oswald, não pode perdoar a entrega passiva da humanidade à justiça arbitrária dos deuses; tampouco aceita a condenação de Prometeu por querer dividir com os homens o conhecimento e a técnica, e aliviá-los da indigência e da escuridão. É importante lembrar, porém, que ele não imputa a Hesíodo ou à Grécia a invenção do patriarcado, mas sim a fixação simbólica das transformações de uma era para a outra. "No Egito, diz ele, o Patriarcado desaparece na noite milenária dos tempos e do velho poder matriarcal restariam apenas alguns símbolos esparsos, entre os quais a esfinge e Ísis” (VM, 1972, p. 203).

Dando continuidade à história da ascensão do patriarcado, passa a avaliar as relações de Aristóteles com Felipe da Macedônia e Alexandre, o Grande. Para tanto, cita novamente o filósofo-jurista Hans Kelsen, dessa vez para esclarecer as ligações entre monoteísmo e o Estado na ontologia aristotélica:

A teoria metafísica do Ser que pretende ser uma ontologia constitui na realidade uma axiologia, uma teoria do valor absoluto e, portanto, uma teologia, pois a perfeição ou bondade corresponde à essência do real e, por isso, todo real é, em certo grau, bom; isto se verifica com especial acuidade nestas palavras: 'o Ser não podia ser mal administrado. A salvação não está no comando de muitos, um só domine'. (CFM, 1972, p. 98)

A essa altura, nota-se que a genealogia traçada por Oswald abre mão de uma rígida cronologia em nome de uma escala ampla, que intercala espaço de séculos sem constrangimentos. Assim, ele vai costurando a história do patriarcado 
por meio de alusões a algumas especulações clássicas da história das religiões: a origem do monoteísmo no Egito, com o faraó Akhenaton; o surgimento da ideia de Juízo Final na Pérsia, com a mitologia masdaísta e a figura de Zaratustra etc. Por fim, transcreve uma compilação de textos religiosos sobre o tema da obediência, retirados de uma edição de S.E. Frost, no qual aparecem juntos Budismo, Cristianismo, Confucionismo, Hinduísmo, Judaísmo, Maometismo, Sikhismo, Taoísmo e Zoroastrismo, todos misturados no caldeirão do patriarcado.

Contudo, é Sócrates quem merecerá destaque especial na sua reconstrução do discurso patriarcal no mundo antigo. Com o filtro antropofágico, Oswald refaz o trajeto nietzscheano responsabilizando-o pela popularidade da chamada "moral dos escravos", e ainda o acusa de puritano, inaugurador do primeiro DIP ${ }^{55}$ e do "triste teatro de tese dos Diálogos, dirigido e formalista"56(CFM, 1972, p. 94). Em síntese, Sócrates teria dado o golpe fatal no sentido lúdico e matriarcal da Grécia arcaica.

Como se pode prever, reaparece aqui a mencionada ambiguidade da sua leitura de Nietzsche. Nesse caso, ela aparece na combinação entre o retrato de Sócrates como traidor do pensamento grego (por suas concepções racionalistas e moralistas sobre o bem e a verdade) e como um "compêndio de atenções para com as classes poderosas" (CFM, 1972, p.91), "com seu ódio de classe, com seu desprezo pelo povo, pelo 'comum das gentes"” (CFM, 1972, p. 92); imagens que, como já dissemos, dificilmente sensibilizariam Nietzsche.

Alguns anos antes, Oswald comentava que Nietzsche não havia entendido completamente que a moral socrática, "apesar de carregada de um tom de conquista social", no fundo "era a oposição individualista ao ciclo dionisíaco que

\footnotetext{
${ }^{55}$ Departamento de Imprensa e propaganda, responsável pela censura no Estado Novo.

${ }^{56}$ Ao fundo desta ironia com os diálogos socráticos, pode-se ouvir uma autocrítica velada, já que o próprio Oswald se embrenhou pelo "teatro de tese" nos anos 30, quando escreveu suas três obras dramáticas mais famosas ,A morta, $O$ rei da vela e $O$ homem e o cavalo. No ensaio "El regreso de los muertos vivos: O rei da vela de Oswald de Andrade" (2010) Gonzalo Aguillar cita uma passagem emblemática desse período, escrita por Oswald em 1937 para um prefácio a suas obras: "Dou a maior importância a A morta dentro da minha obra literária. É o drama do poeta, o coordenador de toda ação humana, a quem a hostilidade de um século reacionário afastou pouco a pouco da linguagem útil e corrente. Do Romantismo ao Simbolismo, Surrealismo, a justificação da poesia se perdeu em sons e protestos ininteligíveis e parou em balbucios e telepatia. Longe dos chamados populares. Agora, os soterrados, através da análise, voltam a luz e através da ação chegam as barricadas" (ANDRADE apud AGUILAR, 2010, p.25)
} 
a precedera". (MT, 1972, p. 26). Longe do pensamento "tribal" judaico, foi dela que brotou "o cinismo de Diógenes, o ceticismo de Pirro e o hedonismo de Epicuro". (Ibidem).

Em resumo, Oswald rejeita Sócrates por três frentes diferentes e aparentemente contraditórias entre si. Por um lado foi o pedagogo da moral de rebanho, por outro a voz do aristocratismo grego e por último o arauto de uma filosofia individualista.

$\mathrm{Na}$ verdade, Nietzsche lamentava a decadência da antiga aristocracia grega e acusava Sócrates de ser um dos responsáveis por isso. Como explica Keith Ansell-Pearson, Nietzsche repudiava os ensinos socráticos, não apenas por terem conduzido os gregos ao otimismo teórico de reformar a sociedade em nome de uma ordem social justa calcada em princípios racionais, mas, fundamentalmente, porque "Sócrates não se dispôs a revolucionar o conteúdo da moralidade ateniense, ou a criar uma nova moralidade, mas a conferir à moralidade comum a consciência de si mesma que lhe faltava" (Ansell-Pearson, 1997, p. 81).

Não há dúvidas, portanto, que Oswald faz uma leitura parcial de Nietzsche. Acompanha-o no repúdio a "metafísica de rebanho" socrática, mas ignora o desprezo categórico de Nietzsche pelo destino do próprio rebanho e termina por agregar à filosofia deste uma lista de reivindicações sociais.

A sensação que dá é que Oswald quer evitar as alternativas pastor de rebanho / aristocrata assumido, e improvisa um meio termo pouco convincente. $\mathrm{Na}$ sua soma final, moral de escravos e moral de senhores compõem os dois lados da mesma moeda patriarcal: “(...) a 'moral de escravos’ presidiu a criação da técnica e ao seu desenvolvimento. E, com ela, a moral do senhor. A opressão necessária" (DD, 1990, p. 130)

A apresentação de Sócrates como figura de proa das concepções patriarcais se prolonga por várias páginas. Em alguns casos, vale registrar, Oswald lança mão da sua clássica veia paródica, como ao insinuar que em $O$ Banquete, enquanto faz um discurso cheio de falso moralismo, "por baixo e por cima da mesa, Sócrates se deixa disputar pela bolina de Ágaton e de Alcebíades, numa cena digna do romancista americano Henry Miler" (CFM, 1972, p.93). Ou ainda, quando duvida de seu heroísmo ao tomar a cicuta, questionando o que Sócrates 
estaria, de fato, deixando para trás “(...) setenta anos surdos e cegos (...) na ilegalidade e na miséria sob a perseguição e clamor público. Quando não, ao lado de Xantipa "a mais insuportável de todas as mulheres passadas, presentes e futuras", no testemunho de Xenofonte" (CFM, 1972, p.95).

Blagues à parte, o que se destaca das observações sobre Sócrates é a abordagem dialética da sua figura histórica:

Ele (Sócrates) se coloca exatamente no pórtico daqueles tempos novos anunciados por minerva, no final da Oréstia. É toda a transformação de um clima. A Grécia que possuía uma unidade homérica se esfacela na guerra do Peloponeso, auge das suas atribulações internas. A Grécia dionisíaca, que produziu, na medida clássica do século $\mathrm{V}$, a sua ordenação plástica e lírica, decai nas dissensões entre os aristocratas e o povo. A Grécia fora o mar e, portanto, o comércio, daí ter surgido nela a indústria e o proletariado urbano. E consequentemente as primeiras experiências da questão social. Sócrates é a oposição a toda a medida eufórica que os gregos guardavam de sua alta antiguidade. Contra o politeísmo, ele lança o Deus único. Contra o sentido precário da vida de Heráclito, ele lança a imortalidade da alma. Contra a visão conflitual do mundo de Empédocles, lança a imutabilidade do Bem.

O que redime Sócrates é a sua sinceridade (...). Sua atitude, frente à Grécia arcaica, é de fato revolucionária. E como foi um progresso a escravidão que tirou o homem do seu estado primitivo, também a teologia socrática constitui um passo à frente no caminho das conquistas da civilização. $\mathrm{O}$ messianismo que brota de suas convicções imortalistas e que depois a figura do Cristo centralizaria, vem dar alimento interior às populações proletárias que iniciam nas bordas do Egeu, a marcha técnica do homem. O sobrenatural não está longe do milagre físico que a técnica cria. (CFM, 1972, p.95)

Nessa etapa revolucionária nas conquistas da civilização, Sócrates preparava o terreno para a expansão de uma nova cultura que vai se estabelecer, de fato, em Roma. Com o fim da era antiga abria-se uma lacuna espiritual que exigia ser preenchida. Para Oswald, livros como De natura Deorum, de Cícero e Assembléia dos Deuses, de Luciano Samossata, escancaram "uma disponibilidade órfica sedenta de novos deuses e novos altares" (OA, 1991, p. 237). Em outras palavras, a elite bem informada do mundo civilizado não estava mais disposta a entregar seu destino às desventuras de Júpiter, Marte, Vênus e companhia. Por outro lado:

Em Alexandria, encruzilhada de dois mundos, apresentava-se uma religião feroz, racial e particularista que não podia seduzir o homem saído do classicismo grego. 
A Bíblia traduzida pelos "Setenta" $" 57$ não teve força para atrair o alexandrino estóico ou cético. Ela levaria até Roma a tolice paradisíaca de suas fábulas e o infame Decálogo atribuído a Moisés. Mas era na própria Roma, a maior concentração proletária do mundo antigo, que se haviam de ouvir as forças para uma nova construção religiosa. (OA, 1991, p.238)

O cristianismo messiânico congregou, em seu início, tendências opostas em um só discurso. Foi uma religião de justiçadores e uma moral de escravos. Elevou o sentido social e individual. Segundo Oswald, isso foi possível porque a figura de Cristo era capaz de projetar imediatamente as aflições do homem comum. Logo, Jesus, filho do carpinteiro de Nazaré, era o primeiro deus proletário. Os evangelhos, por sua vez, reproduziam uma curiosa moralidade de raízes sinóticas que, "longe do faquirismo asceta de Buda e além dos divertissements olímpicos", defendiam um "código de bem viver no trabalho e para o trabalho" (CFM, 1972, p.83). Não bastasse isso, a noção de Parúsia (volta vingadora do Messias para estabelecer a justiça na terra) facilitaria o proselitismo cristão, pois encarnava o milagre pelo qual esperavam todos os escravos e demais excluídos das riquezas do Império.

Oswald não deixa de destacar que as condições econômicas exigiam novas configurações políticas, fato que favoreceu a ascensão da ideologia cristã. A cultura romana estimulava o mercado, que inchava até o limite com as conquistas imperiais. Os latifúndios, por consequência, exigiam cada vez mais mão de obra. Porém, "Os exércitos imperiais haviam sido derrotados em Teutburg e não puderam conter a independência balcânica. "Latifundia perdidere Italia" - gritava Plínio” (MT, 1972, p.27). Em tons marxistas, conclui: “A superestrutura exorbitou da estrutura. E a derrocada se produziu, conduzida ideologicamente pela revolução cristã” (MT, 1972, p. 26).

Como de costume, ao lado do olhar macro histórico brota a interpretação moral e psicológica. Dela provém o último e decisivo fator da revolução cristã, creditado ao apóstolo Paulo ${ }^{58}$. De acordo com Oswald, "sem Paulo, o escravo não

\footnotetext{
${ }^{57}$ Tradução grega do Antigo Testamento, realizada a partir do hebraico por volta de 250 e 130 a.C.

${ }^{58}$ É bem lembrada por Rodrigo Petrônio a rixa de Nietzsche com Paulo, que deve ter influenciado a leitura de Oswald. Apontado como o grande responsável pela síntese entre Atenas e Jerusalém, para Nietzsche, Paulo era o "primeiro moderno. O primeiro democrata". (PETRONIO, 2010, p. 584)
} 
teria pleiteado a dignidade individual em cristo, que foi a longínqua semente da revolução burguesa" (CFM, 1972, p.84)", tampouco haveria conferido honrarias a monogamia (marca patriarcal por excelência). Obediência e castidade uniam-se formando um importante código patriarcal.

\begin{abstract}
A revolução pauliniana de um lado é a semente da própria revolução burguesa que dormitaria sob as invasões e os enxertos raciais e étnicos da Idade Média, para germinar no humanismo renascentista. De outro é o apostolado agreste de Cristo que vem confirmar a lei patriarcal. Revolucionária é a ideia da igualdade de todos em Cristo, isto é, sob uma bandeira que transcende as fronteiras imperiais de Roma. "Não há agora nem Judeu nem Gentio, nem escravo nem livre, nem homem nem mulher, mas vos sóis todos um em Jesus Cristo" - diz a Epístola aos Gálatas. Revolucionária torna-se a posição do escravo monogâmico, detentor individual da dignidade humana. Da mesma Epístola aos Gálatas é aquela afirmação: "O homem não é justificado pelas obras da lei mas pela fé" que através de Agostinho daria a apologia do arbítrio em Lutero e o -consequente "estado de graça" do burguês que prospera no comércio ou no roubo. Estão ai delineadas dialeticamente as etapas da cultura patriarcal (CFM, 1972, p.97)
\end{abstract}

Ernest Cassirer disse que, embora as visões de mundo estoica e cristã não fossem necessariamente hostis (não raro, inclusive, aparecem mescladas num mesmo pensador), a busca pela independência absoluta do homem, considerada uma virtude essencial para o estoicismo, "transformou-se na teoria cristã em seu vício e erro fundamentais. Enquanto nele perseverasse, o homem não teria caminho possível para a salvação" (Cassirer, 1977, p.26).

É da perspectiva dessa tensão de condutas que Paulo é visto por Oswald como o malicioso arquiteto do ethos que nublava na mesma atitude, submissão e autonomia, revolta e sujeição, num pano de fundo messiânico salvacionista. Esta teria sido a fórmula penetrante que garantiu a duradoura estabilidade do individualismo patriarcal, mesmo diante do revés da promiscuidade e desregramento das tribos matriarcais que desmantelaram o Império Romano e tiveram seus hábitos perdurados no decorrer da Idade-média.

$\mathrm{Na}$ visão de Oswald existe uma cronologia das ideias que se sobrepõe à cronologia das datas. Por esta lógica, Paulo faz parte de uma linhagem de pensamento que contempla influências tão diversas quanto o decálogo, Kant, Maquiavel, Loyola e Lênin. A premissa desta "escola" pode ser resumida na máxima maquiavélica de que "os fins justificam os meios". Ou seja, forçados ou 
não, os seres humanos deveriam obedecer à negação de sua natureza em nome de um bem maior.

\section{4 .}

\section{O homem natural tecnizado}

Chegamos à famosa tríade antropofágica de explícita influência marxistahegeliana:

1 termo: tese - o homem natural (Matriarcado)

2 termo: antítese - o homem civilizado (Patriacado)

3 termo: síntese - o homem natural tecnizado (Matriarcado tecnizado)

É um tanto desconcertante como, conscientemente ou não, Oswald propõe um esquema escatológico-salvacionista na própria tese em que expõe a crise da filosofia messiânica, por meio de uma seleção de críticas as suas ilusões metafísicas.

De certa forma, o paradoxo está no cerne do pensamento antropofágico e não há como nem porque dissolvê-lo por completo. Ocorre que mesmo fundado sobre uma visão de mundo imanente (a devoração), a antropofagia não descarta a influência da imaginação do transcendente (orfismo) na vida dos homens. E, no fundo, é sobre as variadas feições desta dialética que discorre a filosofia oswaldiana.

Dito isso, existe uma explicação parcial para a controvérsia do esquema hegeliano de A crise da filosofia messiânica, que é a distinção que Oswald faz entre os conceitos de utopia e messianismo. Embora ambos tratem do futuro e de profecias sobre o destino dos homens e do mundo, o primeiro tem como horizonte a transformação da realidade pelas ações e soluções coletivas (em vida, na terra); enquanto o segundo investe na resignação à origem metafísica da verdade e na salvação individual (após a morte). 
Para Oswald, as religiões e filosofias messiânicas, fossem para iludir ou libertar, dissimularam a natureza primitiva e inconfessável do homem. Contudo, esse elemento primitivo negado ao longo da história, parecia-lhe ser exatamente aquilo que vinham reivindicando Kiekergaard, Nietzsche, Schopenhauer, Freud, além de toda onda de existencialistas da primeira metade do século XX. Para ele, a tematização do absurdo e do ilógico no lugar do Bem como fundamento da vida era o retorno de um olhar primitivo recalcado por séculos de metafísica.

Em termos míticos, Oswald conjecturava que deveria ter existido qualquer coisa antes da árvore do bem e do mal e do fogo prometeico, que nos levaram à condição de sofredores. Essa coisa foi turvada pela civilização, mas ao mesmo tempo parecia alimentar subterraneamente seus dogmas com uma disponibilidade insaciável para os sonhos de redenção. Assim: "Foi necessária a vinda de Marx e de Nietzsche e mais tarde de Freud para que se pudesse, enfim, identificar esse obscuro compromisso que o homem traz arraigado em sua psique para com todas as miragens que lhe propõem, o que foi durante o passado a mola invisível de todas as religiões" (OA, 1991, p. 249).

Oswald propunha que vergássemos a torneira dos sentimentos órficos para a direção das utopias. Mais especificamente, para a utopia de reconquista da natureza do homem pela técnica, que é exatamente o terceiro termo do esquema: o famoso "bárbaro tecnizado". Esta imagem foi expressamente apropriada do filósofo alemão Hermann Keyrserling e está presente desde o Manifesto antropófago. À época modernista, o conceito estava intimamente vinculado ao contraste entre cultura e civilização que, em 1949, Oswald sintetizou da seguinte forma;

À cultura podem-se ligar dois conceitos: o de sentimento e o de caráter. À civilização dois outros: o de razão e o de técnica. Cultura é o que somos. Civilização é o que realizamos. Assim sendo, Cultura vem a ser a alma de um povo, de uma etnia, de uma área histórica. Civilização, ao contrário, é espirito, é política, é técnica. Aquela é Pathos, esta é Logos (...).

Cultura é língua, foclore e comida, vestuário e religião, enfim, o que dá originalidade a um grupo étnico e a sua área geográfica. Civilização é matemática, water-closet, libertação de preconceitos, rádio, esperanto, divórcio, leis sociais. (CD, 1991, p. 203) 
Tratava-se, então, de atualizar os ganhos técnicos da civilização, sem destruir aquilo mesmo que nos definia: nossa cultura. Segundo Haroldo de Campos, a antropofagia propunha um nacionalismo modal em oposição ao nacionalismo ontológico. O que significava "pensar o nacional em relacionamento dialógico e dialético com o universal" (Campos, 1981, p. 11). Nesse cenário, o "bárbaro tecnizado" era uma imagem que vinha a calhar, pois, no ambiente em que ferviam os debates sobre qual seria o melhor projeto para a construção de uma identidade nacional autônoma, ela se encaixava perfeitamente no programa antropofágico de dissolução da eterna dicotomia entre o ufanismo romântico e a modernização cientificista.

Além disso, tanto a metáfora específica do "bárbaro tecnizado" quanto a da própria antropofagia, confluíam para um tema central de quase todas as vanguardas no mundo inteiro: a da relativização dos valores implícitos aos conceitos de civilização e barbárie. Embora não tenha abandonado as questões em torno da identidade nacional, creio que este último debate seja mais determinante na abordagem filosófica da antropofagia dos ensaios.

A essa altura dos acontecimentos, Oswald aborda, cada vez mais, a luta entre logos e pathos de um ponto de vista universalista, psicológico e antropológico. Nesse sentido, "bárbaro" ou "homem natural" aparece muitas vezes como sinônimo de uma instância psíquica contígua ao homem histórico. São suas pulsões reprimidas e sublimadas pela civilização. Por outro lado, o adjetivo "tecnizado" está menos relacionado ao acesso à técnica, do que ao modo como se é afetado pelas mudanças sociológicas decorrentes dela.

Por esses motivos, o "homem natural tecnizado" não é exatamente um índio usando a internet (conquanto nada o impeça de ser), mas antes uma abstração do indivíduo por vir, liberado do mal-estar civilizatório e do trabalho, por consequência inevitável da história e do progresso sócio-tecnológico.

No mundo supertecnizado que se anuncia, quando caírem as barreiras finais do Patriarcado, o homem poderá cevar a sua preguiça inata, mãe da fantasia, da invenção e do amor. E restituir a si mesmo, no fim do seu longo estado de negatividade, na síntese, enfim, da técnica que é a civilização e da vida natural que é a cultura, o seu instinto lúdico. Sobre o Faber, o Viator e o Sapiens, prevalecerá então o Homo Ludens. À espera da devoração do planeta pelo imperativo do seu destino cósmico. (CFM, 1972, p. 83) 
Nos seus cálculos utópicos ainda deveríamos superar dois entraves de ordem psicossocial: a conquista do ócio e a transformação do tabu em totem. Nos dois casos a antropofagia procede pela inversão de mitos patriarcais.

Começando pelo tema do ócio. Se aceitarmos que os mitos são formas narrativas que servem tanto para explicar causas misteriosas quanto para ocultar impasses de origem, pode-se dizer que, assim como o matriarcado tem seus fundamentos na Idade de ouro, ociosa, orgíaca e comunista, o patriarcado também tem suas fantasias de base. Uma delas remonta ao mito sócio-político da "acumulação primordial", na qual vemos a história de dois trabalhadores: um preguiçoso e perdulário, e o outro diligente e empreendedor ${ }^{59}$. Entretanto, esta narrativa tão inerente ao nosso código moral, não só ofusca a violência das origens do Estado, como não explica muita coisa, uma vez que pressupõe como dado o que pretende elucidar. Ou seja, explica a acumulação primordial, tendo como modelo o comportamento de um trabalhador no estágio maduro do capitalismo $^{60}$.

Por outro lado, o romântico arquétipo matriarcal, segundo o qual teria havido uma sociedade que experimentava a vida de forma natural, imediata e harmônica, por estranho que possa parecer, talvez esclareça alguns detalhes das origens ideológicas do Estado. É o que explica Slavoj Zizek, ao afirmar que para Marx essas sociedades pré-divisão de classes, de fato, poderiam ser consideradas pré-ideológicas, pois embora aquela vivência imediata acarretasse em um sem número de "ilusões" (por exemplo, da divinização da natureza), a ideologia propriamente dita:

Só emerge com a divisão do trabalho e a cisão de classes, quando as ideias "erradas" perdem seu caráter imediato e são elaboradas pelos intelectuais, a fim de servir (para legitimá-las) às relações de dominação existentes - em suma, somente quando a divisão entre Senhor e Escravo conjuga-se com a divisão do próprio trabalho em trabalho intelectual e físico. (Zizek, 1997, p. 24)

\footnotetext{
${ }^{59}$ É conhecida a versão de La Fontaine, na qual os dois personagens aparecem sob a forma da cigarra imprudente e da formiga ressentida. Existe, porém, uma impagável versão "antropofágica" de Monteiro Lobato, em que, chegado o inverno, a formiga abre alegremente as portas do formigueiro, agradecida a cigarra por toda aquela cantoria que amenizava os dias de labuta.

${ }^{60}$ (ZIZEK, 1997)
} 
Seguindo a lógica marxista, Oswald acredita que a divisão da sociedade depôs os mitos matriarcais para estabelecer uma ideologia que elitizou o privilégio do ócio (para o sacerdócio) e difundiu a sua negação (o negócio) como regra natural e necessária da vida comum. Não há duvida, afirma ele, que a escravidão e a sua consequente justificativa ideológica (o messianismo) renderam saídas mais eficazes na luta pelo domínio da natureza. No entanto, com o alto progresso tecnológico atingido nos últimos séculos, todo aquele aparato psicossocial parecia se tornar inútil:

O ócio não é esse pecado que farisaicamente se aponta como mãe de todos os vícios. Ao contrário, Aristóteles atribui o progresso das ciências no Egito ao ócio concedido aos pesquisadores e aos homens de pensamento e de estudo. A palavra ócio em grego é sxolé, donde se deriva escola. De modo que podemos facilmente distinguir dentro da sociedade antiga, os ociosos como os homens que escapavam ao trabalho manual, para se dedicarem à especulação e às conquistas do espírito. No fundo de todas as religiões como de todas as demagogias, está o ócio. O homem aceita o trabalho para conquistar o ócio. E hoje, quando pela técnica e pelo progresso social e político, atingimos a era em que, no dizer de Aristóteles, "os fusos trabalham sozinho", o homem deixa sua condição de escravo e penetra de novo no limiar da Idade do Ócio. É um outro Matriarcado que se anuncia. (CFM, 1972, p. 82)

A conquista do ócio pela técnica era um dos passos para desconstrução da psique do homem histórico. O outro seria a "transformação do tabu em totem". Este lema é tão célebre e repetido quanto obscuro. Na maioria das vezes em que Oswald se refere a ele, o faz de forma cifrada e elusiva, e parece querer menos esclarecer o que diz do que alimentar intepretações em torno dos eixos da antropofagia.

Comecemos, então, lembrando a tese antropogênica de Totem e Tabu, à qual o conceito faz clara alusão. Nela, Freud desenvolve sua hipótese a partir da associação entre três teorias diferentes. A primeira é a de Darwin, que, pela observação dos símios superiores, deduziu que o homem primitivo deve ter vivido originalmente em grupos pequenos, nos quais o ciúme e a preponderância do macho alfa impedia a promiscuidade sexual, e obrigava os mais jovens a correr atrás do seu próprio harém, estimulando assim a exogamia. A segunda é a de William Robertson Smith, que verifica na cerimônia do sacrifício animal e em seu 
banquete ritual a origem comum a todo o sistema totêmico que caracteriza as tribos primitivas. A terceira é a própria psicanálise. Notando a ambivalência do sentimento de amor e ódio que o primitivo nutre pelo totem, Freud conclui que ele é um substituto do pai, e a partir dai elabora seu mito:

Certo dia, os irmãos que tinham sido expulsos retornaram juntos, mataram e devoraram o pai, colocando assim um fim à horda patriarcal (...). O violento pai primevo fora sem dúvida o temido e invejado modelo de cada um do grupo de irmãos: e, pelo ato de devorá-lo, realizavam a identificação com ele, cada um deles adquirindo uma parte de sua força. A refeição totêmica, que é talvez o mais antigo festival da humanidade, seria assim uma repetição, e uma comemoração desse ato memorável e criminoso, que foi o começo de tantas coisas: da organização social, das restrições morais e da religião. (Freud, 2012, p.91)

Segundo Freud, a culpa resultante do ato teria gerado dois tabus determinantes para as sociedades humanas. O primeiro pela divinização e proteção do pai, desde então, projetado na figura do totem. O segundo pela consciência de que os desejos sexuais não unem, mas separam os homens. Como o antigo macho alfa, o provável era que todos os irmãos desejassem todas as mulheres do clã para si. Evidentemente, isso levaria a um estado generalizado de guerra. Assim, se queriam viver juntos, seria necessário instituir a lei contra o incesto e renunciar às mulheres do clã que tanto desejavam e que tinham sido a principal causa do assassinato do pai.

Em um primeiro momento, podemos inferir da ideia de "transfiguração do tabu em totem" a inversão do esquema freudiano pela destituição da culpa como fundadora da sociedade humana, ou, mais precisamente, pela deposição da cultura fundada nos tabus patriarcais. Como observou Benedito Nunes, a cultura patriarcal "fixou no trauma do sentimento de culpa, o poder do pai como superego e, portanto, como principio exterior de realidade, coercitivo e inibitório do princípio interior de prazer" (Nunes, 1972, p. xliv). Logo, se essa presença constante do tabu, internalizado na forma de repressão e culpa é a marca da evolução psíquica do "homem vestido", "totemizar o tabu" significaria, a princípio, "desrecalcar" o "homem natural" latente, isto é, as pulsões reprimidas pela lei do patriarcado. Esta liberação exercida pela transformação do tabu em totem seria a ação por excelência da antropofagia, que em todo seu sentido 
polissêmico, opera "a transmutação do valor oposto em favorável, do limite e da negação em afirmação" (IM, 1991, p. 104).

De fato, desde o Manifesto, Oswald acusa Freud de ser apenas o outro lado do catolicismo e, no fundo, o um identificador de males catequistas. Para ele, o que Freud fazia era apenas cadastrar a "moral da cegonha", o que terminava por legitimá-la como real. Num sentido específico, então, a "transfiguração do tabu em totem" aspira à renúncia da concepção "platônico-cristã" da sexualidade, trazendo-a de volta para a vida.

Apesar da importância prática do gesto (principalmente em 1929), a verdade é que, à época do pós-guerra, a repressão sexual cristã já era um alvo razoavelmente banalizado pelos escritores no mundo inteiro. Além do que, justiça seja feita, ao apresentar o homem como um animal sem acesso a si próprio e determinado por pulsões inconscientes originadas em traumas sexuais, Freud não estava exatamente aliviando os alicerces da "subjetividade platônico-cristã", seja na sua centralidade racional, seja no seu moralismo religioso-sexual.

Talvez por isso nos ensaios filosóficos a postura de Oswald em relação a Freud mude um pouco. Embora siga apontando o espectro patriarcal da psicanálise, Freud passa a ser tratado com alguma deferência e situado entre os "três gênios do século XIX", ao lado de Marx e Nietzsche. Por outro lado, as noções de inconsciente e primitivismo passam a dialogar de forma mais sofisticada.

De qualquer modo, mesmo na época do Manifesto e da Revista de Antropofagia, Oswald já insinuava relações bem menos elementares entre o tabu e o totem. Por exemplo, quando indicava uma tensão dialética entre as duas instâncias, pela qual o homem transforma eternamente o presente. Em função disso, em algumas ocasiões, ele comenta a necessidade de "transfiguração permanente do tabu em totem", dando um sentido transitivo e holístico ao fenômeno. Ganha importância, nesse caso, o aspecto dinâmico das relações de conservação e liberação em todos os setores da cultura, muito mais do que a simples necessidade de superação do tabu. No seu entender, tanto a vida individual como social consistem num contínuo violar (ou totemizar) e erigir 
tabus diários, resultando numa lógica distinta do ato fundante e do trauma, tal qual aparecem no mito freudiano.

Deste ângulo, o conceito desafia às noções de estabilidade e origem que ligam as diversas esferas do pensamento e da cultura à tessitura metafísica. Como observou Alexandre Nodari, a antropofagia almejava não uma encenação do começo da história varias vezes (como os rituais totêmicos dos irmãos parricidas de Freud), mas iniciá-la a cada vez que se realizava:

Em jogo está o estatuto da própria ideia de fundação e/ou de origem - e,com isso, da história: se a fundação é um evento único que inaugura a história, e que só podemos celebrar ritualmente, ou se, pelo contrário a história é um eterno presente que pode ser transformado em infinitos gestos de fundação. (Nodari, 2010, p. 465)

Por último, Oswald também tematizou a função exogâmica da totemização do tabu, como sinônimo de exteriorização do sentimento órfico no ambiente coletivo. Dessa vez, totemizar simboliza promover o sentido comunitário em contrapeso à engrenagem internalizada e privativa da lei no tabu.

Esta ideia parte da suposição de que nas sociedades civilizadas o desenvolvimento da propriedade privada aprofundou o egotismo natural do indivíduo e, consequentemente, aumentou seu sentimento de distância e antagonismo em relação à comunidade.

Seguindo o mesmo raciocínio pode se concluir pelo contrário nas sociedades primitivas. Ou seja, a partilha do trabalho, da terra e dos bens levavam a uma maior sensação de pertencimento ao grupo e a uma menor tendência à hostilidade dentro do mesmo (e maior com as outras tribos). Por conta disso, segundo o antropólogo Robert Briffault (citado por Oswald); "a solidariedade do clã totêmico era um traço decisivo na história social do povo (primitivo) e tinha precedência sobre qualquer outra consideração" (AHC, 1972, p. 142).

Algum mecanismo psicossocial foi perdido durante o processo civilizatório que isolou cada vez mais o indivíduo, abandonando-o ensimesmado diante do mistério da vida e da morte. É claro que com a civilização veio também o domínio da natureza, o desencantamento do mundo e o amadurecimento do 
homem pela racionalização dos fenômenos que o rodeavam. Para Oswald, no entanto, a imaginação humana não pode deixar de fantasiar, agonizar e idolatrar:

o sentimento de adoração continua a existir, puro ou não, tradicional ou transferido. É uma necessidade que parte tanto da vida individual como da vida coletiva. Na verdade, os fortes, os ascetas, os vocacionais de tebaida sentem fluir em sua solidão os melhores êxtases. Mas o homem é um animal coletivo. Daí a extrema importância do Rito e da Igreja, seja que Rito for e que Igreja for. O grande alemão Romano Guardini disse admiravelmente que a Liturgia é mais importante que a Ética. E é verdade. Está isso provado em milênios de experiência religiosa. A ética geralmente é uma imposição do sacerdócio que beneficia o seu ofício. A Liturgia é a exteriorização de um sentimento pelas cordas do social. Na liturgia há um ato fundamental de solidariedade humana. Enquanto a Ética reprime o ser, a Liturgia fá-lo ecoar. (OC, 1972, p. 289)

Evidentemente, os termos rito, igreja e liturgia são usados em acepções amplas na citação acima, podendo vir a ser reconhecidos, por exemplo, no modo como se idolatravam os ícones da nascente indústria cultural. Assim, dizia ele, na década de 1950, futebol, cinema e política tinham virado religião. Desfilavam como deuses, Stalin, Hitler, Mussolini e Lenin. Ao lado, sábios, santos e igrejas, vinham sendo substituídos pelos atores e atrizes nas revistas e jornais: "Deusas são Greta Garbo, Joan Crawford, Carlito" (Ibidem). O que Oswald argumenta é que algo da ordem da crença e do culto religioso parecia-lhe indissociável da psique do homem, e caso isso não fosse totemizado e interpretado em sentido comunitário, fatalmente ganharia as dimensões messiânicas do tabu.

Aparentemente o progresso técnico já estava tratando de fazer esse serviço. Sua aposta era a de que através dele uma visão de mundo antropofágica retornava. Primeiro pela eliminação dos últimos vestígios do trabalho escravo, depois pela dessacralização das religiões oficiais e sua abertura para uma expressão livre e comunitária do orfismo. Em outras palavras, chegava a hora do "homem natural tecnizado".

É curioso que a crescente transferência da idolatria religiosa para os mitos modernos pelas mãos da reprodutibilidade técnica, que tanto assustava Benjamim, soava como caminho normal e, em vários sentidos, liberador ao olhar de Oswald. Mesmo depois de toda nociva manipulação de massas do nazismo e do fascismo. 
Uma vez que o êxito na terra substituía a esperança do paraíso celeste, seguia uma previsível crise de valores e, logo, novas relações com a morte, o trabalho, a sexualidade e assim por diante. Frente a "morte de Deus" e de tradicionalismos análogos, Oswald não via com maus olhos o clima lúdico que se formava em torno da "glória de Tarzan" e da "glamour girl". Tudo aquilo the parecia uma expressão espontânea e bem vinda da confusão provocada pela obsolescência dos mandamentos de Moisés. Era o patriarcado que agonizava.

Assim sendo, o frenesi moral e cultural que não parava de crescer deveriam ser os primeiros sinais do retorno ao matriarcado. Oswald observava com uma mistura de admiração e espanto que "voltamos ao que na Grécia se chamou de hetairismo, uranismo e outros baitolismos ${ }^{61 "}$ (DD, 1990, p. 129), sem contar que "a mulher anda nua, com três cores de cabelo por ano (...) celibatária ou divorcista (DD, 1990, p. 130). Ninguém mora mais, pois não existe mais casa; também não se morre mais, e sim, se aceita de cabeça erguida a eutanásia e a cremação.

Entretanto, “todos esses terríveis sustos que já se vão tornando hábitos banais são o passivo de um crédito imenso feito à liberdade" (DD, 1990, p.130). Era preciso, então, compreender o que significava tudo isso para a massa democrática que surgia na história. Tarefa que se mostrava impossível para duas das correntes filosóficas mais em voga na época: o existencialismo e o marxismo.

Apesar de ambas terem exercido grande influência na arquitetura teórica da antropofagia ${ }^{62}$, para Oswald, elas estavam por demais comprometidas com suas origens patriarcais para interpretarem a visão-de-mundo que se expandia por todos os cantos do planeta no pós-guerra.

De um lado, o evangelho apocalíptico e messiânico de Marx virou "sacerdócio empedernido e dogma imutável na URSS" (CFM, 1972, p.225). A mais-valia manteve-se intacta sob o disfarce de "excedente". O Estado, que deveria se dissolver ao poucos, assumiu a idolatria em volta da qual o marxismo

\footnotetext{
${ }^{61}$ Heitarismo: poligamia.

Uranismo/baitolismo: homossexualismo.

${ }^{62}$ Como se pode ler numa entrevista de 1947, na qual, comentando os livros que lhe influenciaram, diz Oswald: "A Bíblia e o Manifesto comunista tiveram sobre mim grande influência. Quando retirei minha inscrição do PCB, experimentei uma livre e excelente recuperação mental. O existencialismo robusteceu minhas posições de 28 - a Antropofagia” (pg 122)
} 
tornou-se a metafísica proletária. "O que sucede hoje ultrapassou de muito os limites do razoável. Há, por exemplo, até uma maneira proletária de tirar as asas da mosca de laboratório". (VNL, 1991, p. 217)

$\mathrm{Na}$ outra ponta, os existencialistas, apesar de resgatarem o irracionalismo e uma postura matriarcal em relação à morte, não conseguiram expandir o projeto, sendo contidos pelas raízes de seu individualismo patriarcal. Resultado: terminaram relegados à busca pela subjetividade pura e, consequentemente, ao retorno à metafísica. Ou, em outros termos, "ao Ser como tal, o grande impostor da velha Metafísica" (CFM, 1972, p.122).

Nesse quadro, Oswald ensaia alguns elogios ao pragmatismo americano, como um sistema mais adequado para lidar com as transformações existenciais que seguiam em processo:

\begin{abstract}
A América nos deu a filosofia do êxito em contraponto a filosofia do desespero, brotada da subjetividade pura de Sören Kierkegaard. Enquanto nas ruas de Copenhague a solidão de uma grande doente lançava a angústia como base da realidade humana, nascia em Nova York o criador otimista do pragmatismo, reclamando a redução da filosofia ao intuicionismo, à experiência e à vontade. Daí para cá acentua-se no mundo essa maneira prática e eficiente de encarar e resolver os problemas da existência pelo seu rendimento útil. Daí para cá, os EUA são os mestres do mundo moderno. E quando Lênin morreu, foi seu melhor testamento o conselho dado aos bolchevistas: "Americanizai-vos!" (CD, 1991, p.112).
\end{abstract}

Oswald manteve até o fim uma simpatia moderada pela postura dessacralizante e anti-metafísica do pragmatismo americano. Não se pode dizer, porém, que morria de amores pelos Estados Unidos. Pelo contrário, tinha bem reservado seu quinhão de sarcasmo e crítica ideológica ao país, como será visto adiante.

No geral, então, as observações acerca das afinidades entre a cultura de massa, o pragmatismo e a antropofagia, no limiar de um novo matriarcado tecnizado, tinham uma clara função estratégica: apresentar a mentalidade europeia como caduca, reservando ao "jovem" continente americano a função de vanguarda da humanidade.

Não fazia sentido para Oswald que nós, com a opulência do nosso primitivismo que sempre se sentiu em casa no ilógico e no absurdo, que nunca 
divisou muito bem onde era o paraíso e onde era o inferno, fosse agora "se ajoelhar no Café de Flore, diante de Sartre e Simone Beauvoir" (TEL, 1996, p. 212).

Pelo mesmo motivo, quem poderia conduzir melhor a democratização do "Otium cum dignitate" 63 dos aristocratas romanos, do que a miscelânea matriarcal do continente americano. Pois, como dissemos, para ele, este processo já estava em curso e "através das leis sociais, dos estádios gigantescos, da televisão e do rádio e também do turismo a prestações - folgados bens atingem as camadas mais desfavorecidas da sociedade. Há uma democratização do ócio, como uma democratização da cultura" (AM, 1972, p. 209).

A questão era saber: o que buscou o homem ao longo de todos esses longos séculos de guerra, diligência e progresso intelectual e material? Para Oswald a resposta já estava dada por Aristóteles: que os fusos trabalhem sozinhos e que pudéssemos nos ver livres da penúria. A mecanização já estava pronta para substituir o escravo. A passagem de uma mentalidade para a outra, porém, não seria simples:

\begin{abstract}
Nada há que suntuosamente coroe melhor a revolução industrial do que o domínio fecundo e intimativo da técnica. O robô é um ideal. Sem dúvida a transição é dramática. Nada mais doloroso que a desumanização produzida pelo cálculo, pela inflexibilidade do cálculo, pela certeza do cálculo. E sejamos francos, nada mais inumano que a certeza. (AM, 1972, p. 208)
\end{abstract}

Acima de tudo, o trajeto para o matriarcado tecnizado era dramático porque significava a passagem de uma cultura da servidão para uma cultura da liberdade. Sem Paulo ou Lutero, sem a virtude socrática, sem a razão cartesiana ou a certeza moral kantiana, o homem por vir teria que resolver sua experiência no mundo, sem sujeição consciente. Seria necessário forjar outra mentalidade, diversa da que acorrentou Prometeu e se revoltou inconformada, de Orestes a Hamlet, sempre que se deparou com a liberdade de carne e osso da mulher.

Por aqui, vivíamos uma situação ambígua diante da crise do patriarcado. Se por um lado ela tinha o peso de uma caricatura (num país em que o

\footnotetext{
${ }^{63}$ Ócio com dignidade - Cícero
} 
parlamentarismo chegou antes da abolição da escravidão), por outro, nossa elite conservadora não tinha as defesas das culturas de patriarcalismo inveterado. "Ora, nós não temos graves arquivos nem pesados compromissos heráldicos. Aqui o homem é mais importante do que a lei!” (DD, 1990, p. 124) 


\section{4 \\ O ciclo das utopias}

A guinada ensaística da antropofagia ocorre nos anos imediatamente posteriores ao fim da Segunda Guerra Mundial. Talvez isso explique a atenção dedicada por Oswald às utopias. Naquele momento, apenas germinavam as incalculáveis revisões das crenças modernas. O ideário humanista-iluminista ${ }^{64}$, embora já cambaleante, ainda servia de farol para as projeções de reconstrução e reinvenção do mundo por vir.

Um par de décadas mais tarde aquela tradição seria duramente atacada pelo pensamento pós-moderno. De um lado, porque o comunismo totalitário e o imperialismo tardio deixaram evidente o desinteresse pelas lições trágicas da Guerra, gerando amplo ceticismo entre os intelectuais quanto a real possibilidade de regulação dos interesses corporativos e estatais por valores humanistas.

Por outro lado, porque a chamada "crise da representação", apesar das raízes antigas e controversas, incentivou uma intensa desconfiança acerca do que a modernidade definia como verdades racionais, dando origem a um onipresente desejo de desarticulação das antigas meta-narrativas, de suas pretensões fundacionistas e sistemas totalizantes de pensamento. Em seu lugar, cresceu o interesse por teorias que descrevessem o tempo e a história como fenômenos fragmentários, com sentidos contingentes e carentes de lógica intrínseca.

Uma das consequências mais notórias da crítica pós-moderna foi a da negação da historiografia elaborada a partir do século XVIII em diante. Como afirmou Habermas (2002), esse discurso se alicerçava nas estruturas da filosofia racionalista, calcada, entre outras coisas, na premissa da relação de representação

\footnotetext{
${ }^{64} \mathrm{O}$ termo humanismo pode comportar muitas acepções controversas. Embora tenha surgido para designar a redescoberta das literaturas grega e romana e do sentido de unidade dos seres humanos e da natureza, expresso por elas, no período renascentista, o humanismo era bastante consistente com a crença religiosa e católica em particular. Segundo o Dicionário Oxford de filosofia: "Mais tarde, o termo acabou por se tornar apropriado aos movimentos sociais e políticos anti-religiosos. Atualmente, o termo tem sido por vezes usado num sentido pejorativo pelos autores pósmodernistas (...). (BLACKBURN, 1997, p.187). É nestes dois últimos sentidos que estamos empregando o termo.
} 
entre pensamento e realidade e na ideia de conhecimento como busca hermenêutica da verdade.

As últimas décadas assistiram a um rompimento de proporções inéditas com esses $\operatorname{conceitos}^{65}$, que controlavam os modos de acesso e de escrita da história e, em consequência, a própria história. Com a difusão da ideia de que o pensamento e a realidade não refletem especularmente um ao outro, e que, portanto, o ato de conhecer tem afinidades com o ato de inventar ou transformar, a antiga concepção de história forjada na modernidade começou a ruir, e, com isso: “(...) a ideia de documento (histórico) portador de sentido é questionada tão radicalmente quanto a própria atividade de interpretação" (Habermas, 2002, p.351).

Ora, sabemos que, desde o Manifesto Antropófago, escrito bem antes da Segunda Guerra, a antropofagia já criticava a noção de história da tradição iluminista. Àquela época, Oswald bradava por "Um mundo não datado (...). Sem Napoleão. Sem César" (Andrade, 1972. p. 16). O quê, então, o teria levado a se interessar por uma revisão da história ocidental, tal qual a concebe de 1945 em diante?

Duas respostas vêm à mente. A primeira é que, entre o Manifesto e os ensaios, Oswald mergulhou no engajamento político de esquerda, voltou de lá marcado pelo marxismo e, consequentemente, por um olhar histórico e dialético. A segunda é que, ao se voltar para a teoria, decidiu pormenorizar aquela história "não datada", contemplando de modo "genealógico" os aspectos encobertos pelas versões dominantes da formação da civilização ocidental.

Nesse sentido, a antropofagia ensaística apresenta uma relação flutuante com a crítica contemporânea: ao dar continuidade às boutades do Manifesto, se aproxima de algumas de suas correntes de pensamento, mas ao convocar o marxismo e o humanismo utópico tende a se distanciar da maioria delas.

\footnotetext{
${ }^{65} \mathrm{Na}$ realidade, desde que foi elaborada no século XVII, a filosofia racionalista a qual nos referimos acima, foi sistematicamente criticada em diversas ocasiões. Até se estabelecer com solidez no pensamento moderno, o racionalismo e a correlata noção de progresso, tiveram um caminho árduo, de longas e variadas batalhas, não só contra os filósofos empiristas, mas também contra as mais variadas empresas religiosas, tradicionalistas e românticas, que buscaram, cada uma a sua forma, alertar sobre os seus supostos perigos. Da segunda metade do século XX até hoje, porém, a crítica ao racionalismo apresentou novas e radicais facetas no ambiente das ciências humanas, negando, inclusive, o seu estatuto de ciência.
} 
Foucault, que foi sem dúvida um dos principais artífices da atual suspeita em relação às categorias racionalistas e universalistas modernas, faz a seguinte afirmação em seu texto Maneiras de se escrever a história:

A crítica contemporânea está começando a formular, sobre os diversos textos que ela estuda, seus textos objeto, uma espécie de combinatória nova. Em vez de reconstituir seu segredo imanente, ela apreende o texto como um conjunto de elementos (palavras, metáforas, formas literárias, narrativas) entre os quais é possível fazer surgir relações absolutamente novas (...). As relações formais que assim se descobrem não estavam presentes na cabeça de ninguém; elas não constituem o conteúdo latente dos enunciados, seu segredo indiscreto; são uma construção, mas uma construção precisa desde que as relações assim descritas possam ser atribuídas realmente aos materiais tratados (Foucault, 2000, p.69).

Pode-se dizer que esta é uma descrição mais do que adequada à maneira como Oswald se utiliza da tradição ocidental para formatar seu pensamento heterodoxo, pleno de associações e conclusões insuspeitadas. À maneira de Foucault, os ensaios se compõem por inusitadas relações textuais, que sucedem pontos de vista originais sobre antigos objetos (textos objeto).

De outro aspecto, a antropofagia também pode se colocar a léguas de distancia dessa "nova crítica contemporânea". Principalmente quando assume o tom de engajamento social utópico, tão categórico no vocabulário da época, quanto tímido no cenário apocalíptico atual. Nesse caso, à diferença do que defende Foucault, Oswald se empenha justamente em apontar "o segredo indiscreto" e o "conteúdo latente" dos discursos canônicos.

O que ocorre é que, embora os ensaios comecem a ser escritos exatamente no momento em que ele rompe com o partido comunista, negando seus dirigentes e sua cartilha política, um certo viés filosófico do marxismo jamais é abandonado. Seu olhar, frequentemente, gira em torno do âmbito de noções como ideologia, fetichismo, luta de classes, dialética da história etc. Não obstante, a forma peculiar do seu trato estilístico e conceitual permite-lhe uma abordagem incomum dessas noções, provendo-lhes a flexibilidade ausente entre os intérpretes ortodoxos, devotos da suposta cientificidade do marxismo, que aquela altura Oswald já rechaçava com veemência e ironia. 
Enfim, o que me parece atual e singular nos ensaios antropofágicos é que as demandas individuais e coletivas, argumentos essencialistas e relativistas, fazem parte do mesmo programa teórico, alternando sobre questões normalmente compartimentadas pelo raciocínio dicotômico da tradição ocidental. É claro que, por esse motivo, os textos incorrem em contradições e ambiguidades insolúveis, porém não necessariamente obscuras e intangíveis, já que a visão de mundo antropofágica repousa em um explícito a priori binário: a oposição entre uma cultura da liberdade e uma cultura da servidão. Para Oswald: "A filosofia nunca foi uma disciplina autônoma, ou a favor da vida ou contra ela, iludindo os homens ou neles acreditando, a filosofia dependeu sempre das condições históricas e sociais em que se processou". (CFM, 1972, p. 79)

Posto esse breve pano de fundo, para começarmos de vez o quarto capítulo sobre os ensaios antropofágicos, é preciso apresentar o conceito que irá costurar parte essencial de suas releituras históricas: a Utopia.

No fundo de cada Utopia não há somente um sonho, há também um protesto. Não é outro o sentido do grande estudo de Karl Mannhein intitulado Ideologia e Utopia, esse de que ao contrário da ideologia que procura manter a ordem estabelecida, toda Utopia se torna subversiva, pois é o anseio de romper com a ordem vigente.(...)

De modo que, como o sociólogo eminente generaliza o conceito de ideologia (mentalidade vigente), é necessário estender também o conceito de Utopia. Por isso assinalei aqui a fraqueza de visão crítica daqueles, para quem Utopia é somente a obra renascentista de Morus e Campanella. Ao contrário, e aí está Mannheim para esgotar o assunto, chama-se de Utopia o fenômeno social que faz marchar para frente a própria sociedade. (MU, 1972, p. 195-96)

A Utopia para Oswald é a pólvora que desperta a insubmissão e precede as transformações de cada sociedade. Ao destacar o conceito, seu intuito é chamar a atenção para um fenômeno que extravasa o sonho e invade a realidade social. Por isso, o termo será utilizado com desembaraço nas análises históricas, e vários acontecimentos servirão como exemplos de gestos utópicos.

A dilatação da Utopia e sua recontextualização em variados momentos de mudança cultural segue um procedimento parecido com o adotado por Mannheim em relação à noção de ideologia. Para este, o problema era o de escolher entre as acepções de ideologia ampla (estilos culturais, épocas, visões de mundo) e 
fechada (de veio político, designando a ideia de falsa consciência para legitimação do poder). Alfredo Bosi explica a solução adotada:

A obra clássica de Mannheim foi escrita no momento em que a sociologia da cultura começava a tocar o limite do próprio relativismo, interrogando-se a si mesma sobre sua própria validade enquanto saber condicionado. Se a ciência da sociedade identifica a condição dependente e relativa das ideias e dos valores de cada visão de mundo, onde encontrar o locus livre e autônomo da verdade, isto é, quem pode proferir juízos de valor fora ou acima do seu próprio nicho social? Daí a oscilação, a meu ver fecunda, de Mannheim entre manter o veio historicista das suas matrizes (insistindo na efetividade dos estilos culturais com suas coerentes visões de mundo) e aproximar-se exploratoriamente do conceito marxista de ideologia, presumindo como suspeitos de falsa consciência aqueles discursos com que os estratos dominantes de todas as épocas pretenderam legitimar o seu poder. (Bosi, 2010, p.75)

Esta oscilação de Mannheim entre as duas concepções de ideologia é intensamente assimilada por Oswald, que mira alternadamente os condicionamentos culturais e as manipulações políticas de cada época. Quando propõe fazer o mesmo com o conceito de Utopia, Oswald não só quer misturar as instâncias do imaginário e da vida cotidiana, como quer dar importância aos efeitos práticos e históricos da manipulação do simbólico originada em outras camadas sociais, que não a do topo da pirâmide ${ }^{66}$.

Assim, somos apresentados ao "Ciclo das Utopias", nome sugerido para o período histórico que se inicia no século XVI, com a divulgação das cartas escritas por Américo Vespúcio em sua viagem pelo Novo Mundo, e culmina com o Manifesto Comunista de Marx e Engels. O "Ciclo", entretanto, extravasa sua cronologia circunscrita, de forma que o molde utópico da modernidade é prenunciado muito antes dela, ao longo de toda a história antiga e medieval.

Um bom exemplo é o caso do "primeiro cristianismo", classificado por Oswald como "uma Utopia herética tanto em face do Sanhedrim judaico como do

\footnotetext{
${ }^{66}$ Implicitamente está em jogo, também, a subversão da clássica ideia marxista em voga na época: a da infra e da super-estrutura. Segundo essa concepção haveriam "condições reais de existência", as condições de produção, troca e consumo de determinada sociedade, isto é, sua infra-estrutura, em contraposição à super-estrutura (religiões, artes, ideologias) que seria apenas um reflexo da primeira. Embora não negue completamente o esquema marxista, Oswald procura diluir a divisão fixa e vertical entre fenômenos materiais e simbólicos.
} 
poderio político romano" (MU, 1972, p.196). No capítulo em questão, ele ressalta o valor que o

termo grego Parúsia - “destinado a indicar a volta do Deus vingador para repor as coisas em seus eixos numa situação social errada" (MU, 1972, p.196)- alcançou de início e como continuou a motivar, tacitamente, as "heresias" ao longo de toda a Idade Média:

O cristianismo foi no seu início uma religião de justiçadores. Como toda religião fabricada ela devia seguir certas diretivas psicológicas capazes de atrair para o seu culto um grande número.

Quando se forjaram os evangelhos, vinte anos depois da morte do Cristo, eles se fizeram em torno de uma esplêndida ideia, a da parúsia. A parúsia era a volta vingadora do Messias ressuscitado e subido aos céus, volta que liquidaria as injustiças sociais e destroçaria os tiranos do mundo. Era um milagre à vista pelo qual esperavam os humildes pescadores, os vagabundos e os expulsos das grandezas da terra (...).

Contra os desvarios de uma corte de gozadores infames, que eram os habitantes do Olimpo ou os vagos tótens esquecidos nas migrações forçadas das levas cativas (...) o cristo chibatado, suplicado, morto na irrisão era a solidariedade imediata para as vitimas da desigualdade social.(...) O suplício da cruz era tão natural e comum que, num só dia, em Jerusalém, Tito fizera crucificar dois mil judeus.(...).

Foi Clemente de Alexandria, no decorrer do século V (sic), o responsável pelo estorvo ideológico que transferiu para a vida futura as vantagens fulminantes da parúsia. Foi ele o primeiro sacerdote cristão a admitir a possibilidade oficial de um rico penetrar impune no reino dos céus. O cristianismo deixava com ele sua missão revolucionária e social.

Coincidiu com a ação de Clemente de Alexandria a oficialização do cristianismo como religião de Estado romano pelo imperador Constantino. "Façamos a revolução, antes que o povo a faça", foi a fórmula oportunista que encontrou o neo-convertido.(...) ( OA, 1991, p. 238-239-240)

Seguindo seu raciocínio, as "heresias" teriam herdado o legado revolucionário do primeiro cristianismo ao renegarem a autoridade da Igreja medieval em favor da manutenção do ideal parusaico de justiça em vida, mesmo quando profeticamente adiada. Isso o levaria à conclusão de que "No fundo de cada heresia há, pois, uma Utopia. E essa Utopia se dobra e recobre do ideal parusaico" (MU, 1972, p. 198).

O conjunto das "heresias", portanto, formará parte importante do que Oswald considera a mentalidade "pré-utópica". O Arianismo, os valdenses e o catarismo são alguns dos casos mencionados como exemplos das rebeldias 
heréticas na Idade Média, "quase todas liquidadas a ferro e fogo" (MU, 1972, p.196). Contudo, o feito herético que merece maior destaque da parte do autor é o milenarismo, ligado ao abade Joaquim de Flora e suas ideias panteístas, "as quais às vezes tomaram certa coloração comunista, ameaçando mesmo a legalidade das riquezas folgadas do papado" (MU, 1972, p. 199).

Várias são as características do milenarismo que atraem Oswald. Entre elas, o subversivo senso de urgência, ligado à crença na iminente segunda aparição messiânica, prestes a estabelecer um reino de mil anos de fraternidade na terra. Essa ideia ia de encontro ao que pregava a Igreja com a imagem do Juízo Final, que dividia a existência entre o céu e o inferno.

Além disso, apesar do papel central do messias, o milenarismo era uma doutrina marcada pela consciência social e pregava a prática comunitária da fé. Muitos dos diversos séquitos milenaristas, inclusive, praticaram o estilo de vida santo e comunitário, convencidos de que o millenium já havia chegado ou estava prestes a chegar.

No caso de Joaquim de Flora, a transição estava marcada para o ano 1260. "O ano veio e o milenarismo, como a antiga parúsia, foi adiado" (MU, 1972, p. 199). De acordo com Oswald, porém, seu legado teria atravessado a Idade Média como vestígio da Parúsia, chegando a influenciar movimentos tardios como as revoltas camponesas alemãs do século $\mathrm{XVI}^{67}$ : "Foi, sem dúvida, essa utopia panteísta lançada pelo abade de Calábria e trazendo em si um fermento de revolução social, que tentou todos os cérebros da Idade Média. Basta dizer que Thomas Münzer, o grande predecessor e opositor de Lutero foi um milenarista" (MU, 1972, p.200).

Para Oswald, as resistências "heréticas" eram sintomas de uma indignação de fundo matriarcal contra as instituições do patriarcado. Além delas, chamava-

\footnotetext{
${ }^{67}$ Krishan Kumar, no livro Utopianism, afirma mais radicalmente que a influência do milenarismo viria a assumir a forma secular a partir do século XVIII, tendo a ciência e a revolução como substitutos do papel do messias: "Nineteenth-century social philosophers, too, often appeared to be merely rehearsing the scheme of the most influential millennial thinker, the twelfth-century Calabrian monk, Joaquim of Fiore. Joaquim's doctrine of the Three Ages, culminating in the Love, peace and freedom of the Age of the Holy Spirit, seemed to find a direct echo in the philosophies of history of Saint-Simon, Hegel and Marx. Saint-Simon's scientific society, Hegel's age of the actualized Spirit, and Marx society of full communism all carried strong millennial overtones.(So too, in a grotesque parody of Three Ages philosophy, did Hitler's Third Reich) (KUMAR, 1991, p.11)
} 
lhe a atenção outros aspectos negligenciados pelo senso-comum sobre a Idade Média. Eram sinais matriarcais ligados a duas origens interdependentes: a decadência do "patriarcado romano", após as invasões bárbaras; e a interrupção do comércio com o Oriente, seguida da necessidade de substituição da escravidão pela servidão:

É necessário insistir sobre o caráter matriarcal que tomou a Idade Média em face do derrocamento do poderio patriarcal romano. (...) No entanto, historiadores e sociólogos esquecem essa fase essencial de transformação dos costumes do Ocidente, que o cristianismo mesmo vitorioso e oficial não poderia deter de modo nenhum. Pode-se afirmar que desde o século V até o IX (...) o que presidiu a vida incerta e nômade da Europa foi o mais completo e livre estado de poligamia. Isto ligado a uma concepção do bem-estar geral que fugia a qualquer cogitação de acumulo de riqueza e exploração de classe (...).

Na história conhecida já se constatara a existência de fases pseudocapitalistas ou mesmo capitalistas entre os povos mais avançados da terra. A vida em certas regiões do Oriente, como no Egito, atesta esse fenômeno. Mas o grande "rut" que liquidou o Império Romano era realizado não por povos tão superiormente organizados e evoluídos. Tratava-se de hordas do tipo matriarcal que vinham afogar as tradições jurídicas patrilineares da cultura romana nas ondas impetuosas e desregradas de sua fome e de sua seiva sexual. De que modo o Direito Romano, que havia sido apenas condensado por Justiano nesse mesmo século $\mathrm{V}$, poderia opor as suas barreiras legalistas a essa humanidade sedenta de usufruição e de gozo que vinha das invasões? Em que língua poderiam padres, pretores ou rábulas moralizar aquelas frenéticas populações vazadas no fundo dos abismos do mundo, que só conheciam a liberdade do amor e a realidade da presa?

Uma curiosa poudrie tem nublado essa fase da história do Ocidente a fim de que se perca o seu caráter profundamente marcado pelo regime matriarcal que nela deixou impressionantes vestígios. Somente a fecundidade jorrada e renovada do coito livre poderia, no primeiro desequilíbrio do mundo medieval, fazer resistir essa amálgama humana aflitivamente abatida pelos revezes da fome e da peste, da guerra e da anarquia e trazê-las até dias mais claros. (OA, 1991,p. 263-64)

Segundo Oswald, "o realismo da vida livre do medievo sexual" foi deturpado pela moral dos escritores cristãos. Isto teria resultado, entre outras coisas, no encobrimento das reais influências do avunculato $^{68}$ na eleição de soberanos, da bastardia nos costumes de todas as classes e da exaltação da sensualidade feminina, explicitada sem falsos pudores nos poemas provençais.

Afora isso, ele chama a atenção para as diferenças entre aquela economia sem comércio, calcada no "justo preço" e na condenação do lucro intermediário, e

\footnotetext{
${ }^{68}$ Instituição de supostas raízes matriarcais que designa o domínio da família pelo tio materno, uma vez que naquele sistema teoricamente poligâmico não existiria a figura do marido e do pai, no pleno sentido que lhe atribui o patriarcado.
} 
uma economia de acumulação, só tardiamente recuperada na aurora do Renascimento, de onde sairia "das indústrias florescentes da Itália e de Flandres a figura esquálida e faminta do assalariado" (CD, 1991, p. 207).

Evidentemente, Oswald não ignora as virtudes da emergente burguesia em favor da idealização cega dos barões e clérigos, sanguessugas que viviam do fisco e da servidão no campo. Ao contrário, faz questão de realçar os ganhos decorrentes da revolução forjada nos burgos contra "o ócio feudal, baseado em prerrogativas e brasões" (CD, 1991, p.208). Ressalta, igualmente, que "o dinheiro, atomizando o poder, destacando-se da pessoa do seu possuidor, foi o campeão das franquias e liberdades do homem comum no Renascimento" (CD, 1991, p.209).

Entretanto, bem menos elementar é sua constatação de que na moral medieval havia uma franca oposição entre valores vitais e valores econômicos. Tal organização social, baseada nos códigos de "ajuda e amizade", ao invés do código burguês de "igualdade e trabalho", se apoiava na ideia de que "a vida cotidiana se misturava à vida supraterrena. Não era aqui no mundo que terminava a existência" ${ }^{69}$ (OA, 1991, P. 266)

Toda essa argumentação de tons aparentemente conservadores, ganha maior clareza quando Oswald desenvolve os detalhes históricos:

Desde o ano Mil, os burgos florescem fazendo face ao castelo. Mais que um símbolo, Veneza, a cidade sem terra, a cidade dos canais, defronta o espírito de latifúndio medieval. A república dos doges nunca deixara de comerciar com Bizâncio e com Islã. E os primeiros objetos que oferece aos mercados do Oriente em troca de especiarias e tecido são escravas brancas para os haréns asiáticos e madeira e ferro com que o sarraceno virá atacar o cristão pela posse do mundo ocidental. É esse aspecto gelado do comércio, colocado pela ganância, acima e fora do mundo moral que fez a longa corrente dos que a ele opõe valores éticos e humanos (CD, 1991, p. 207).

Nota-se como o desvelamento histórico do matriarcalismo medieval tem a intenção concomitante de contrastar o lado coletivista daquela concepção de vida

\footnotetext{
${ }^{69}$ Neste ponto, é curioso reparar como a retórica da "vida supraterrena", argumento messiânico por excelência, é convenientemente realocada por Oswald, agora com signo positivo e refletindo a pureza dos valores éticos matriarcais, em oposição a rapina materialista das monarquias absolutistas e da burguesia nascente.
} 
com a face individualista da ascendente ética liberal. Nesse sentido, ao tomar o sentimento anti-comercial como base da argumentação anti-individualista, Oswald parece querer desligar uma costumeira relação que se faz entre valores humanistas e conquistas burguesas liberais. Na sequência, ele chama a atenção para o fato de que na ética medieval, como nas velhas éticas comunitárias da Antiguidade, as obrigações de um indivíduo para com o bem comum não se destacavam de sua auto-realização, sugerindo, com isso, que os valores humanitários deitam raízes muito mais profundas do que as conquistas do indivíduo moderno que tanto envaidecem a tradição ocidental.

Assim, forjando uma corrente humanista matriarcal, Oswald cria uma genealogia de personagens tão variados quanto Jeremias (contra a Babilônia), A Patrística (contra Roma), Erasmo de Roterdã, Shakespeare e Molière (contra o burguês renascentista). E, por último, evoca Cervantes:

O fino iluminista Miguel de Cervantes fechou esse ciclo decisivo da história do Ocidente com uma gravura genial. O Dom Quixote de La Mancha é a epopeia do equívoco. Um homem de pendores pedagógicos, formado na leitura dos livros que perfumam a primeira Idade Média, sai de casa, ao claro sol de um dia útil, para endireitar o mundo. Em vez da justeza e da justiça, encontra já instalados nas cidades e pelos caminhos, o lucro, o mercado, a inverdade e a subjugação impune do débil pelo forte. (OA, 1991, p.267)

O desenho antropofágico da Idade Média pressupõe algumas críticas implícitas. Por exemplo, ao chamar atenção para os "dirigismos históricos", Oswald deixa à mostra o lado narrativo e romanesco de toda descrição histórica (inclusive a sua). Não é de outra forma que retrata os invasores bárbaros como: “aquelas populações vazadas no fundo dos abismos do mundo, que só conheciam a liberdade do amor e a realidade da presa" (Ibidem).

De outro aspecto, ao mudar o rosto de um passado cristalizado no nosso imaginário, Oswald não deixa de insinuar a permanente possibilidade de reinterpretações sobre o presente. Assim como características matriarcais na Idade Média foram ocultadas, é possível que estejamos alheios a dados importantes do presente, turvados pela projeção moral que estabiliza valores contextuais como verdade a-histórica, inquestionável ou inevitável. 
Contra essa tendência tão comum, Oswald lança a pergunta de duplo sentido: "Que é a História, senão um contínuo revisar de ideias e de rumos?" (MU, 1972, p.152). Ou seja, ao lado das releituras pelas quais embaralha as certezas sobre o passado, existe a concomitante intenção de repensar as convicções sobre o presente. E a utopia será um recurso para a desestabilização dessas certezas.

Num famosa passagem, Slavoj Zizek pondera que, afora as mais divulgadas formas de ação da ideologia na cultura, a saber, a de doutrina explícita ("falsa consciência", convicções articuladas sobre a natureza do homem e da sociedade) e a de materialidade ideológica (instituições, práticas, rituais, o "poder ou a disciplina foucaultiana"); para além dessas modalidades, existe aquela que se traduz numa espécie de "rede elusiva de pressupostos e atitudes implícitas", isto é, “espontâneas". Esta rede está presente nas opiniões "sensatas", que se referem à "realidade" inevitável de certas estruturas socioculturais. Dessa forma, diz Zizek que:

Parece mais fácil imaginar o "fim do mundo" que uma mudança muito mais modesta no modo de produção. Como se o capitalismo liberal fosse o "real" que de algum modo sobreviverá, mesmo na eventualidade de uma catástrofe ecológica global (...). Assim, pode-se afirmar categoricamente a existência da ideologia qua matriz geradora que regula a relação entre o visível e o invisível, o imaginável e o inimaginável, bem como as mudanças nessa relação (Zizek, 1995, p. 7).

Para não fugirmos do nosso tema, deixemos de lado a crítica de Zizek ao capitalismo liberal para nos concentrarmos na sua noção de ideologia como reguladora do imaginável e do inimaginável. De acordo com essa concepção, mais do que a ilusão que mascara o suposto "real estado das coisas", a ideologia toma parte nas estruturas inconscientes modeladoras do sentido que damos à própria “realidade" por trás dos enganos ideológicos.

Como vimos no capítulo anterior, a antropofagia também admite, ao seu modo, a ingerência inconsciente sobre o que presumimos como realidade. No vocabulário oswaldiano, uma "dimensão órfica" subjaz às emoções, paixões e fantasias da infância à vida adulta, em qualquer povo civilizado ou ajuntamento 
primitivo. "O sentimento órfico é o subterrâneo alimento onde vicejam essas ardentes necessidades irracionais. (...) Eu não me admiraria de ver um ateu rezar. Quando tudo foge, a alma descansa na ilusão consentida” (OC, 1991, p. 290-291). O orfismo:

(..)existe e existirá sempre. Ele afunda na nossa eterna irracionalidade. Podemos talvez transferi-lo do culto de um Deus para o de um fetiche, ou de um homem tornado ídolo, ou de um cometimento, ou de uma ideia. Mas ele permanecerá sempre no fundo irremovível de nossa credulidade e de nossa imaginação. (MU, 1972, p.172)

Reconhecida a inevitabilidade do órfico nos seres humanos, Oswald se dedica a denuncia da sua manipulação usurpadora ao longo da história. Entretanto, além das doutrinas e instituições fraudulentas, ele entende que o controle ideológico começa, exatamente, pela limitação "do quê" se pode imaginar e de "como" se pode argumentar. Não à toa, a antropofagia assume de peito aberto uma especulação histórica e filosófica que não abre mão dos recursos complementares da escrita e da imaginação literária.

Por outro lado, a escolha da Utopia como peça chave da revisão antropofágica também não é gratuita. Tendo em vista que o termo se reporta ao imediatamente impraticável, porém imaginável (Kumar, 1991), o uso do conceito visa, entre outras coisas, demonstrar como uma parcela decisiva da história é feita pelos transbordamentos da compreensão da realidade imediata, incitando sua transformação. O real também é talhado na fantasia.

A essa altura, começamos a entrar de forma mais contundente no debate sobre as relações entre narrativa ficcional e narrativa histórica. De partida, é importante frisar que não pretendo, aqui, fazer tábula rasa das diferenças entre "ficção" e "história". Está claro que, no limite, os dois termos implicam delimitações discursivas distintas e, de forma geral, explicitamente discerníveis. O estudo das semelhanças entre relatos históricos e ficcionais pressupõe a diferenças entre eles. Caso contrário, não haveria motivos para enfatizar tal semelhança.

Além do mais, é importante ressaltar que ambos os conceitos tiveram uma longa trajetória de transformações em seus significados, desde a Grécia até a Modernidade (isto levando em conta apenas o Ocidente), e que não é nosso intuito 
analisar o percurso dessa evolução semântica. A reflexão, portanto, se restringe ao contexto moderno, no qual a "literatura" faz parte do sistema das "artes" e a "história" do sistema das "ciências". Especificamente falando, interessa-nos a questão moderna/contemporânea da dispersão dos marcos discursivos característicos da historiografia, e de como isto afeta a noção de história como discurso científico e a aproxima do discurso literário ${ }^{70}$. Como definiu Walter Mignolo:

\begin{abstract}
A partir de um determinado momento, e para encurtar uma longa história, a reflexão sobre a história e a historiografia seguirão caminhos conflitivamente paralelos: 1. a concepção do devir articulada, por exemplo, em Comte, em Hegel, em Marx e nos rastros que o pensamento de Darwin foi deixando nas ciências humanas; 2 . as tensões entre a historiografia como arte e como ciência em fins do XIX (Mendez y Pelayo, 1883; Benedetto Croce, 1919; Cian, 1896) e sua continuidade nas tensões entre historiografia como ciência explanativa - à maneira das ciências naturais (Hempel, 1965) - e a historiografia como ciência a maneira da literatura (White, 1978). Foi obviamente esse último aspecto que desencadeou grande parte das discussões sobre o tema, tanto nas ciências sociais, como nas humanidades (Mingnolo, 1993, p. 118)
\end{abstract}

Como destaca Mignolo, Hayden White teve importante participação no debate sobre a mobilidade das fronteiras entre história e literatura nas últimas décadas. Sua tese defendia o caráter inevitavelmente literário da historia. Para ele, a história deveria ser vista como cativa do modo linguístico pelo qual procura organizar seu discurso, de modo que a prevalência da explicação narrativa sobre a explanação argumentativa comprovaria sua essência literária. Ademais, o fato do

\footnotetext{
${ }^{70}$ Existe ainda a abordagem das teorias da linguagem para a questão, e que também não pretendemos aprofundar neste trabalho. No âmbito dessas teorias, aponta Mignolo, é preciso distinguir literatura e ficção, bem como, norma e convenção (Mignolo, 1993: 123-124). Assim, primeiramente, é fundamental entender que ficção não é mentira, posto que existe um acordo tácito entre interlocutores sobre o conteúdo ficcional do texto em questão. Pode-se dizer que esse acordo responde a uma convenção de ficcionalidade, enquanto um estudo historiográfico responderia a uma convenção de veracidade.

Por outro lado, nota-se que convenções pressupõem acordos sem "forte imposição", se comparados à norma que implica critérios rígidos para aceitação de uma conduta lingüística. Nesse sentido, as normas literárias não necessariamente se limitam à convenção da ficcionalidade. Haja vista o exemplo das biografias e dos ensaios que, embora não sejam ficcionais, são quase sempre considerados literários.

Assim, talvez seja possível afirmar que a filosofia da história oswaldiana esteja em desacordo com as normas historiográficas rígidas, mas em acordo com as normas literárias. Entretanto, ninguém poderia afirmar, irrevogavelmente, que as teses antropofágicas sejam ficção estrito senso, uma vez que respondem, de certa forma, a convenção de veracidade.
} 
objeto histórico não poder ser submetido ao controle experimental, isto é, ao isolamento laboratorial, como nas ciências naturais, levou White à conclusão de que a história é o resultado de um artefato verbal de conteúdo híbrido entre o inventado e o encontrado (Mignolo, 1993). Com isso, ele pretendeu cercar duas questões de matrizes diferentes. A primeira ligada às regras do jogo (normas e convenções linguísticas empregadas) e a segunda à ontologia dos acontecimentos (o quanto os fatos históricos são "reais" ou "imaginados").

Penso que para a lógica antropofágica que rege a "genealogia" presente nos ensaios, as duas matrizes estão apenas aparentemente separadas. Isto porque, do ponto de vista das práticas discursivas cotidianas, às quais Oswald dedicou especial atenção, essas questões se misturam.

De acordo com Michel De Certeau, existe um uso comum do discurso que pressupõe a experiência da língua e das interlocuções. A ciência se permite esquecê-lo para atingir seus fins de previsão e manipulação dos fenômenos físicos. A filosofia, por sua vez, acredita dominá-lo e conhecer a raiz de sua constituição. No entanto, da perspectiva das práticas cotidianas da linguagem, pode-se afirmar que longe de uma relação de neutralidade, os discursos que almejam a ordenação de tais práticas são antes controlados por elas. Assim, explica De Certeau, a universalidade de entendimento e controle aspirado pela filosofia e pela ciência, podem ser vista, antes, como uma universalidade da obediência às práticas linguísticas do dia-a-dia:

Estamos submetidos, embora não identificados à linguagem ordinária. Como na nave dos insensatos, estamos embarcados sem possibilidade de fuga ou totalização. É a "prosa do mundo" de que falava Merleau-Ponty. Ela engloba todo o discurso, mesmo que as experiências humanas não se reduzam ao que ela pode dizer a seu respeito. (Certeau, 1998, p.70)

$\mathrm{O}$ argumento encaminha De Certeau à conclusão de que o pretenso escopo científico da análise histórica deixa escapar as relações de interlocução em circunstâncias muito particulares de tempo, de lugar, competição, etc. Fica de fora, desse modo, um conteúdo fundamental do jogo linguístico cotidiano, qual seja, a maneira de usar as coisas e as palavras segundo ocasiões contextuais. Isto é, perdem-se aquelas descontinuidades históricas, que Foucault evidenciou como 
os lances do micro-poder, ausentes da história oficial. Para autores como De Certeau e Foucault, portanto, uma análise histórica deveria levar em conta "os quadros normativos como instrumentos manipuláveis por seus usuários” (Certeau, 1998, p. 82)

Parece-me que os ensaios antropofágicos já anteviam essas ideias ao descrever quadros e personagens sonegados pelos "fatos históricos", levando em conta as idiossincrasias humanas, as paixões e afetos que regem nossas ações e ideias no mundo (inclusive as dos grandes personagens e autores que, frequentemente, são "humanizados", "psicologizados" ou "ficçionalizados" por Oswald). Isso sem contar que a convenção da neutralidade e do distanciamento sucumbe diante da interpretação personalista e apaixonada.

É preciso lembrar, porém, que a invenção dentro dos jogos cotidianos, contos e artes de dizer, não é ilimitada, pois obedece a códigos implícitos e regras veladas. O mesmo poderíamos dizer sobre os improvisos filosóficos e redescrições históricas de Oswald, que necessariamente levam em conta a aplicação de códigos comuns e o respeito a certas regras tácitas, sem as quais sua crítica simplesmente se esvaziaria de sentido. Como lembra De Certeau, mesmo na improvisação musical, é preciso conhecer as escalas, até quando a intenção é subvertê-las.

Resumindo, podemos dizer que a antropofagia filosófica aproxima pensamento e existência, linguagem e vida, fazendo com que analisar ou descrever algo implique em se relacionar e, de certa forma, modificar ou recriar este algo. Isso, todavia, não significa que Oswald invente, de modo arbitrário, fatos da sua cabeça. Suas observações são fruto do diálogo com os inúmeros textos e autores citados nos ensaios. Pelo método crítico antropofágico, porém, o autor não abre mão da experiência de se tornar narrador da história que lhe chega às mãos. Ao reler os cânones com independência, resgatar textos marginalizados e, por fim, observar a história de outras perspectivas, esta se reinventa por si só, e, como consequência, produz novos olhares sobre o presente e o futuro.

Assim, voltando à narrativa antropofágica, do mesmo jeito que tenta revelar as insuspeitas diretrizes matriarcais do medievo, Oswald também irá defender a importância da cultura árabe no cotidiano da época. Para ele, os 
séculos de presença moura no mediterrâneo foram importantes fatores de contrabalanço à mentalidade católica patriarcal. Maomé, dessa ótica, seria o desvio da Bíblia e do cristianismo; "um ramo bastardo de casa real que afronta a legitimidade e ataca o parente próximo com o fim de liquidá-lo” (MU, 1972, p.156).

Oswald acusa novamente a 'História' dirigida, dessa vez “em benefício das teses latinas que procuraram denegrir o meridião semita". O fato é que enxerga na cultura árabe traços fecundos da resistência ao conservadorismo e ao sectarismo da Europa cristã:

O ramo semita dos árabes empreendeu por milênios a excursão de seus gens fertilizadores por todos os caminhos abertos ou fechados da terra e do mar e levaria no encantamento das descobertas à modelagem e à criação dos paraísos utópicos que desviaram a Europa do seu egocentrismo ptolomaico.

Os árabes foram tão compreensivos que no grande Califado de Córdoba era permitido o uso de meia dúzia de línguas, desde o árabe clássico dos escritores até o latim eclesiástico e o dialeto que daria o castelhano. Em oito séculos de dominação, não foi imposta a língua do vencedor.

Afirma-se que na batalha de Poitiers, onde Charles Martel deteve o élan muçulmano, foi salvo o destino da Europa. Salvo de quê? Da agricultura? Da técnica inicial que irrigava os campos e construía os primeiros engenhos? Dos contatos iniciais com o pensamento grego? (MU, 1972, p.154)

No início do século, Manoel Bonfim já havia destacado a influência árabe na cultura ibérica. A península não conheceu a fase negra da Idade Média e, pelo contrário, foi a parte "mais culta e próspera da Europa" naqueles dias. Tudo isso porque, embora nunca tenha deixado de ser cristã, uma vez dissipado o poder de Roma, a Ibéria teria preferido a "política liberal” do árabe ao feudalismo bárbaro. Segundo Bonfim: "o caráter sobranceiro do espanhol diz melhor com o cavalheirismo tolerante dos homens do califado, do que com a hierarquia imposta pelo aristocratismo arrogante dos vândalos, godos e suecos" (Bonfim, 2008, p. 41)

Os muçulmanos encerram o último capítulo sobre a história das ideias "pré-utópicas" que ameaçaram os valores patriarcais da Europa setentrional ao longo da Idade Média. No ponto de transição para a Modernidade, Oswald credita à miscigenação entre árabes e ibéricos uma influência determinante na expansão marítima, tendo em vista os caracteres nômade e conquistador dos islâmicos. 
Foram os moçárabes de Espanha e Portugal que povoaram os porões das caravelas e, no pórtico das Utopias, ficou para sempre aquele nauta luso bronzeado do sol atlântico que o chanceler Thomas Morus conta ter encontrado na nave da catedral de Antuérpia e que lhe abriu os olhos para paraísos americanos da Descoberta.(...)

Enquanto o deus único do deserto, deus de caravana, se metamorfosearia transformado no Cristo, em deus de caravela, sob a condução compreensiva da roupeta jesuíta na direção da conquista da América.

Foi essa religião de caravela que presidiu ao arfar das Utopias, principalmente das duas que se colocam na abertura da era da navegação, sonhadas por Morus e Campanella (...)

Vinda da Arábia petrificada e saída do deserto, a gente sarracena se mesclaria na Península para continuar pelos caminhos do oceano o seu impulso exógamo e conquistador, que trazia em si o errático e o imaginoso, a aventura e a fatalidade. E que só havia de estacar nos verdes da Descoberta. Na ilha de Vera Cruz, Ilha de Santa Cruz, Ilha de Utopia, Brasil (MU, 1972, p.155,156,157)

Chegamos à descoberta da América e ao início do "Ciclo das Utopias". A partir daí o Novo Mundo selaria de vez o destino do Ocidente pelo contato com a cosmologia e a cultura do homem primitivo. A Europa vinha se transformando, desde a gradativa falência do papado romano, passando pelas liberdades municipais das cidades italianas, pelo ressurgimento do comércio e, ainda, pela reforma religiosa. Tudo isso, entretanto, não convence Oswald de que seria o suficiente para deslocar as "prateleiras fixas" dos preconceitos medievais, já que: “Também toda a cosmologia dantesca é ptolemaica (...). Não foi só o Papado que quis fulminar Galileu. Calvino exclamava: 'quem ousaria colocar a autoridade de Copérnico acima do Espírito Santo?' E Lutero dizia do sábio revolucionário: 'Esse imbecil quer destruir toda a Astronomia"' (AV, 1972, p. 211).

Na contramão do conservadorismo teocêntrico, a carta Mundus Novus enviada por Américo Vespúcio a Pedro Lourenço de Médici, em 1503, será considerada um marco definitivo na formação da mentalidade ocidental moderna. Oswald acredita que a divulgação das imagens pelas quais o "navegante florentino" descreve as peculiaridades do Novo Mundo inquietou a Europa e desencadeou as Utopias modernas. Para além do céu e do inferno, havia do outro lado do mundo um novo homem, com uma nova cultura e novos valores.

Acima de tudo, a admiração de Oswald por Vespúcio resulta da atitude sem preconceitos que ele supostamente teria tido perante os índios. Diferentemente dele, Pero Vaz de Caminha iria escrever um documento imbuído 
do "mofo medieval das concepções teológicas", no qual se exasperava exclamando, “em primeiro lugar é preciso salvar essa gente! Salvar queria dizer vestir, por sapatões e chapéu e, além de tudo obedecer ao conquistador branco". (AV, 1972, p. 214)

Américo Vespúcio, porém, agira de forma oposta, assinalando a cordura e inocência dos índios e exaltando a liberdade e a igualdade em que viviam, num regime que ignorava a propriedade, a moeda e o comercio. Vespúcio notava, também, a ausência de reis, templos e ídolos. Tudo isso levara o conquistador à constatação que Oswald reproduz e comenta:

Aqueles povos têm "una scelerata libertá di vivere, La quale piu tosto se conviene agli Epicuri Che alle Stolci".

Estava revelando que, na realidade e na prática, era possível viver-se em estado epicúreo. E isso jogava por terra todas as longas e tremendas asceses que tinham presidido à construção do mundo medieval. (AV, 1972, p. 215)

No mais, Vespúcio ainda carregaria o mérito fictício de ter sido o capitão de Rafael Hitlodeu o navegante português que teria, supostamente, se encontrado com Thomas Morus na Antuérpia e o teria marcado de forma profunda com as histórias sobre os costumes das terras desconhecidas, principalmente os da chamada Ilha da Utopia.

É bastante provável que a Utopia de Morus tenha sofrido, de fato, influência direta das cartas de Américo Vespúcio, e que a arquitetura sócioeconômica traçada no livro tenha sido feita a partir do acréscimo fabuloso sobre as notícias (verdadeiras ou não) recém chegadas do Novo Mundo. Ironicamente, inclusive, em determinado momento da descrição da Ilha, ao ser interrogado por Thomas Morus sobre alguns possíveis contratempos de tal organização social, o nauta Rafael Hitlodeu ${ }^{71}$, teria respondido: "Vossa imaginação não poderia fazer a menor ideia duma tal república" (MU, 1972, p.162).

O tratado utópico de Morus também é admirado por outro motivo. Ele iria preconizar as críticas de Marx à devastação da agricultura pela indústria de lã e ao

\footnotetext{
${ }^{71}$ Hitlodeu, ou Hythloday, de acordo com alguns estudiosos significa "distribuidor de nonsenses" (KUMAR, 1991).
} 
processo de proletarização da Europa. O livro varia entre a descrição da utópica sociedade igualitária e considerações de cunho "socialista" sobre a propriedade privada, os deveres do estado, o dinheiro, o trabalho e etc. Outro livro, A cidade do sol, de Tomaz Campanella, escrito no início do século XVII, também será citado em detalhes como exemplo de crítica social e defesa dos ideais coletivistas inspirados nas notícias vindas do além Atlântico.

O que se pode resumir da interpretação de Oswald, então, é que, além da idealização da sociedade proto-comunista inspirada no estilo de vida das comunidades primitivas do Novo Mundo, a Utopia de Morus (como será A cidade do sol de Campanella) reproduz, igualmente, uma crítica ao ócio e as regalias parasitárias da nobreza e do clero medieval. Este era o momento no qual a consciência burguesa dava os primeiros passos e, na sua esteira, surgiam as primeiras denúncias aos privilégios de sangue. Oswald cita J.B. Alberti, importante burguês florentino que teria escrito, em plena Florença do século XV, antecipando o estilo de Benjamin Franklin: "quem não perde tempo tudo consegue, e quem sabe trabalhar o tempo é mestre do que quiser" (MU, 1972, p.166). O igualitarismo das sociedades utópicas de Morus e Campanella, também se embasa neste contexto negativo:

O caminho percorrido pelas Utopias renascentistas conduz a dois pontos altos - o ódio ao ócio, evidentemente ao ócio de classe que produziram as longas e pesadas desigualdades medievais; e à exaltação da comunhão de bens. $\mathrm{O}$ ócio da selva colocava-se assim face aos ócios de privilégio. (MU, 1978, p.176)

Com isso, ao lado de um inegável idealismo, são os componentes críticos do projeto utópico, seu potencial de questionamento, que interessará à antropofagia. Vera Figueiredo observou que:

de todas as representações da América tecida nos anos próximos à descoberta, pelo imaginário europeu, como as de paraíso, céu e inferno, Oswald seleciona a mais racionalizada (...). Interessa-lhe o que há de negatividade, de ruptura com o contínuo da história, de descentramento, no projeto utópico. Articulando o que lhe ficou do pensamento marxista, após o período de militância de esquerda com leituras de Nietzsche, Weber e de antropólogos como Lévi-Strauss, busca, na obra de Karl Mannheim, o conceito de utopia que vai utilizar para caracterizar nossa inserção na história do mundo ocidental. Surgimos como estimuladores de 
mudanças, abalando certezas, sugerindo alternativas, provocando a imaginação alheia: a alteridade é, assim, um valor positivo (Figueiredo, 1994, p.19).

De acordo com Vera, a Utopia contradiz a noção retilínea de progresso histórico, fomentadora da ideia da superioridade civilizatória europeia. Por conseguinte, ela também amplia as possibilidades de tempos narrativos, isto é, não precisaríamos percorrer o tempo lógico e as etapas civilizatórias do colonizador para alcançar o seu estágio técnico no presente. No nosso caso, o "eixo passadopresente-futuro" funcionaria pela lógica da "pluralidade temporal" (Figueiredo, 1994, p. 27). Essa subversão da lógica temporal tradicional remete - agora em sinal positivo - a já citada ideia oswaldiana de que "Existe uma cronologia das ideias que se sobrepõe à cronologia das datas"72 (CFM, 1972: 79).

Assim, voltando ao raciocínio de Vera: "Retomar a América como Utopia, em plena década de cinquenta é procurar situá-la como um espaço de confrontação, retirando-a do contínuo da história para que possa assumir o papel de crítica do Ocidente" (Figueiredo, 1994, p.28).

Silviano Santiago aponta para um caminho semelhante ao lembrar que Oswald elabora uma Utopia original, que nem é a utopia marxista, nem a utopia tal qual definida pelo modelo da Revolução Francesa. Segundo Silviano, para a antropofagia, a Utopia é caraíba:

O saber selvagem, diz Oswald, vem questionando o saber europeu desde o primeiro contato da Europa com a América. De Montaigne a Rousseau, ou seja, passando da crítica às guerras religiosas e à Inquisição e chegando ao bom selvagem de Rousseau, sem esquecer a Declaração dos Direitos do Homem, o Selvagem tem sido o motor da utopia européia. Oswald, com o pensamento e ação antropófagos, visa trazer a utopia caraíba europeia para seu lugar próprio - o Brasil (Santiago, 1991, p.109).

Apesar da proeminência do valor atribuído à alteridade americana, não é só em torno dele que se tece a crítica do conceito de Utopia antropofagia nos

\footnotetext{
${ }^{72}$ Vale lembrar, também, que o Manifesto Antropofágico de 1929 é cheio de aforismos que suscitam essa noção de que, em vários quesitos, o homem primitivo já havia alcançado ideias e instituições ainda distantes ou apenas recém descobertas pelo homem civilizado. Um exemplo clássico: "Já tínhamos o comunismo, já tínhamos a língua surrealista. A idade de Ouro".
}

(ANDRADE, 1972, p. 16) 
ensaios. Houve, na base do nascente humanismo europeu, tendências contraidealistas que despertaram grande interesse em Oswald. Aquilo que caracterizará como "uma geografia do riso, das sátiras e do ceticismo", ou o "avesso da Utopia" e que, segundo ele, pode ser mapeado nas obras de Erasmo, Rabelais e Cervantes.

O que Oswald quer expressar com "avesso das utopias" é o fato de que esses autores, assim como os utopistas, também serão críticos do mundo medieval em declínio e dos valores burgueses ascendentes. Todavia, suas sátiras não atingirão o problema econômico da desigualdade, e, portanto, não se ocuparão das Utopias sociais $^{73}$.

Com Erasmo e Rabelais, então, se configura a "Utopia negativa", "a Utopia que o homem encontra em si mesmo". Para o autor, há mais pensamento em Erasmo, porém, menos literatura, pois "Rabelais já começa a fazer da língua o próprio estofo da sátira” (MU, 1978, p. 181). É assim, por exemplo, que em “Gargantua e Pantagruel” Rabelais esboça uma sátira dos otimismos utópicos de Morus, ridicularizando os personagens de Babedec, filha do rei Amauretas da Ilha das Utopias, e Thaumaste, um sábio inglês, referência direta ao próprio Morus. Antes de tudo, Rabelais é "o primeiro riso ateu, quando atravessado o funesto túnel medieval, a Europa abre os olhos para o homem natural, sem culpa nem redenção" (MU, 1978, p.181).

Erasmo, por sua vez, será tratado por Oswald como o grande precursor das "utopias negativas". Para ele, o Elogio da loucura é uma tentativa de desmoralização da

mentalidade patriarcal, que se consolidava com os primórdios do capitalismo. O que ele vê no livro de Erasmo é uma psicologia social que investe violentamente contra os já claudicantes valores católicos, e ironiza as virtudes da nascente burguesia. "Erasmo não aceita a docta ignoranza de Nicolau Cusano nem abre as veredas do iluminismo devoto", afirma Oswald. De fato, é curioso observar como

\footnotetext{
${ }^{73} \mathrm{Na}$ conferência A sátira na literatura brasileira, porém, Oswald comenta sobre a função social da Sátira: "Qual a sua finalidade? Fazer rir. Evidentemente isso está ligado ao social. Ninguém faz sátira rindo sozinho. A eficácia da sátira está em fazer os outros rirem de alguém, de alguma instituição, acontecimento ou coisa. Sua função é, pois, crítica e moralista. E através da ressonância, a deflagração de um estado de espírito oposto. A sátira é sempre oposição" (SLB, 1997, p. 69)
} 
no longínquo século XVI, o Elogio da Loucura apresenta tiradas de vanguarda modernista:

Logo no início, pergunta o mestre de Roterdão: “Dizei-me se há por acaso um só dia na vida que não seja triste, desagradável, aborrecido, quando não é animado pela volúpia que é o condimento da loucura?" E apela para uma citação de Sófocles: "como é bom viver! Mas sem a sabedoria, pois esta é o veneno da vida!” (MU, 1972, p. 178).

Seja pela utopia ou pela sátira, a verdade é que o século XVI, em geral, é de suma importância para a antropofagia filosófica. Na aurora da modernidade ocidental, Oswald procura resgatar os episódios esquecidos na virada ideológica que destronou a teologia medieval. Seu faro parece detectar a existência de fatos deturpados no edifício da hegemonia capitalista burguesa. Por isso, as grandes descobertas e profundas reviravoltas culturais do século XVI lhe parecem um terreno profícuo. Dizia ele que: "por mais que se queira sofismar, o século XVI foi um século libertino e revolucionário" (MU, 1972, p.170).

Nesse mote, o ensaio número 5 de $A$ marcha das utopias nos fornece uma de suas interpretações mais agudas, que é a distinção que faz entre renascença e humanismo. Novamente, o autor parte do argumento estrutural de que o "sentimento órfico" da humanidade foi e é continuamente explorado pelo sacerdócio e pelas elites de todas as épocas. No caso das elites cristãs, a estratégia consistiu em ocultar a influência dos "mitos pagãos das ressurreições primaveris", do orfismo grego e da contribuição de cultos estranhos à ortodoxia cristã em geral. A outra manobra foi localizar a "revelação na Judeia e negar qualquer validade à de Delfos, de Meca ou de qualquer outro ponto estratégico de que a "divindade" se tenha utilizado ou venha por acaso ainda a se utilizar" (MU, 1972, p.174). Em meio a toda essa "confusão dirigida", ele reclama da associação entre humanismo e renascimento, e como "fez-se disso tudo um bolo crescido do lêvedo do cristianismo" (MU, 1972, p.174).

Nada lhe parecia mais incorreto do que essa conexão. Para começar, enquanto a renascença olhava para o passado grego para se orientar, o humanismo apontou para o futuro, apoiado em suas utopias e sátiras. Se o renascimento representava a nudez redescoberta a partir da proeza técnica de Da Vinci ou 
Rafael, a nudez que inspirava o humanismo era outra e vinha da América primitiva para produzir "não especulações e proezas aladas e perfeitas, mas sim, obras humanas de fazer chorar as pedras" (MU, 1972, p.171). Em suma, Oswald argumenta que o humanismo foi, de fato, um movimento incréu, isto é, contra a fé católica medieval, de modo que:

não há possibilidade de ligá-lo senão por coincidência ou leviandade a ciclos de pensamento anteriores ao século XVI (...) Há uma guerra evidente de oposições entre o Renascimento e o Humanismo. Não é possível atribuir-lhe o mesmo sentido. É mais fácil colocar dentro do Humanismo os grandes reformadores da Igreja do que os Renascentistas. É mais cômoda a posição de Calvino como revolucionário do que de Miguel Ângelo (MU, 1972, p.175).

Oswald faz questão de distinguir a técnica renovadora dos renascentistas do pensamento revolucionário dos humanistas. Por isso, acusa o pensamento católico de tentar "apelar para Dante" e remontar o movimento até Cícero, querendo forjar um "primeiro humanismo". Lembra ainda que mesmo a Grécia resgatada pelos renascentistas era uma Grécia apolínea, moldada pelos interesses do Vaticano, e que foi preciso Burckhardt, Rodhe e Nietzsche, alguns séculos depois, para restabelecer suas dimensões dionisíacas. Na detalhada versão oswaldiana da história,

Na virada do século XVI, Roma perdera o controle da Física, da Geografia e da Moral. Mas o Vaticano enriquecia e pagava. Em torno dele juntou-se uma plêiade de vocações, vinda já de uma nascente mas ótima tradição técnica começada no século XIII e apoiada em Cimabue e Giotto. Nicolau V orientara a Igreja nessa direção feliz do mecenato. E a técnica progrediu a ponto de realizar uma definitiva revolução plástica. Atribui-se a descoberta que teria sido feita por Botticelli, de um grupo escultório grego, a volta à Antiguidade à recuperação de sua nudez. Outra nudez já tinha surgido no horizonte cultural da Europa, com o aparecimento do homem americano. E, se houve um ponto de encontro entre a Renascença e o Humanismo, esse se deu no entusiasmo comum pela natureza que a Idade Média difamava.

Era, porém, tão terrível e grosseiro o preconceito que aureolava o mundo helênico que, quando com as Cartas de Vespúcio e pelas Utopias se divulgou a existência de uma super-humanidade perdida do outro lado da terra, se perguntava a respeito dessa gente: - Serão gregos? Ou pelo menos mediterrâneos? O cristianismo dólico-louro trabalha e deforma tudo. Petrarca protesta contra a ideia de que Cícero pudesse ter ido para o inferno pelo desconhecimento do Cristo. Ele e Sócrates são tidos como "colaboradores do cristianismo"(...) É tão grave a deformação cristianizante que a mitologia pagã passa a ser uma teologia velada, 
as Metamorfoses de Ovídio são a Gênese. Até Homero é um pronunciador (sic) de mistérios católicos (...)

A renascença modela e disciplina grandes assuntos. Sempre o seu triunfo técnico se sobrepõe ao tema, à inspiração e ao sentimento. Enquanto isso, o Humanismo dá estofo das utopias futuras. Ele cria o Direito Natural. Ele produz na longínqua América, a primeira experiência de uma sociedade nova - a República Comunista Cristã do Paraguai. No século XVIII, ele dá os fundamentos da Filosofia das Luzes e realiza a Revolução Francesa. No século XIX consegue o abalo sísmico das agitações liberais. E hoje, mais do que nunca, é no Humanismo e na sua tradição revolucionária que se fundamenta a conquista de uma vida melhor para todos os povos. (MU, 1972, p.175, 176, 177)

Nessa passagem fica patente, mais do que uma simples admiração, uma autentica adesão de Oswald ao legado humanista. Um humanismo, todavia, voltado às suas origens. Ali, no momento em que o choque com a alteridade das tribos americanas inspirou as Utopias de um mundo sem senhores e escravos. Um humanismo, por assim dizer, matriarcal.

Não confundir, portanto, com a história da burguesia, que "é realista, é inglesa", nem com seu individualismo que, na verdade, "enterrou o humanismo". Oswald se referia ao "humanismo clássico, o de Roterdão que deu Erasmo, como o de Giordano Bruno. A França só teve um humanista, Montaigne. Depois disso foi cortesã ou regicida" (SR, 1991b, p. 58).

Em suma, a antropofagia se alinha a um humanismo herdeiro matrilinear da parúsia e de todos os movimentos "pré-utópicos" que renegaram, na antiguidade e na idade média, os privilégios aristocráticos conquistados por meio da escravidão. Igualmente, simpatiza com o humanismo satírico, descendente de uma postura "estoica" que, também, desde a antiguidade, defende a autonomia perante a retórica das elites cultas e do sacerdócio que, pelo monopólio do saber, buscaram manter-se no poder apoiadas nos dogmas e na desinformação.

Como enxerga no sentimento órfico uma dimensão incompreensível, mas necessária do homem, a antropofagia compreende a Utopia como uma maneira libertária de moldar seus anseios e fabulações, seja na forma do sonho de justiça social, seja na da liberdade de opinião e crítica às ortodoxias e ao pensamento dirigido.

É importante, então, notarmos a modulação que adquire o termo humanismo ao passar pelo filtro antropofágico, visto que Oswald compartilha, ao 
menos parcialmente, da crítica ao racionalismo moderno. Não só pelo fato de apostar na irracionalidade latente em todos os gestos culturais, mas também porque sabe que a idealização do racionalismo foi um caminho pelo qual "o branco se chamou de civilizado, insistiu em padronizar sua "superioridade" (...) e justificou todos os privilégios e com eles os racismos e imperialismos" (MU, 1972, p. 190).

Contudo, não se pode dizer que a marca anti-iluminista e anti-humanista que domina parte significativa dos discursos pós-modernos seja a nota dominante nos ensaios oswaldianos. Ao contrário, percebe-se o oposto na sua defesa das insurreições igualitaristas ao longo da história ocidental, bem como na declarada afinidade com a sátira pré-ilustrada contra a autoridade religiosa. Além de que, é inegável que os ensaios se apoiam em universalismos que mal escondem suas raízes iluministas e racionalistas. Para ficar no exemplo mais óbvio, basta lembrar a "dialética antropofágica", analisada no capítulo 2 .

Quem sabe, então, se Oswald tivesse vivido as sucessivas crises (da representação, do sujeito, da história) que atingem o pensamento contemporâneo, não teria concordado com Umberto Eco, quando este disse que: “o problema não é matar a razão, mas pôr as más razões em condições de não prejudicar; e dissociar a noção de razão da de verdade. Esse trabalho honrado não se chama, entretanto, hino à crise. Desde Kant é chamado de "crítica" ou estabelecimento de limites." 74 (ECO, 1984, p. 149).

Desse ângulo, podemos dizer que a antropofagia, mais do que concordar ou discordar do racionalismo moderno, produz uma ampla crítica à tradição do pensamento ocidental, ao longo da qual as inúmeras variantes do legado

\footnotetext{
${ }^{74}$ Sobre a proliferação de "crises" contemporâneas- da religião, da razão, do signo, da filosofia, da ética, da presença, do sujeito - Umberto Eco resume sua ideia: "Tomemos como exemplo uma coisa agradável como a crise de representação; mesmo admitindo-se que quem fala dela tenha uma definição de representação (coisa que frequentemente não ocorre), se é que entendo bem o que eles querem dizer - e, isto é, que não conseguimos construir e trocar entre nós imagens do mundo que tenham certeza de adequar a própria forma, admitindo-se que ela exista, deste mundo -, pelo que sei a definição dessa crise iniciou-se com Parmênides, continuou com Górgias, deu não pouca dor de cabeça a Descartes, constrangeu a todos com Berkeley e Hume e assim por diante, até a fenomenologia (...). Mesmo que se admita, contudo, a antiguidade da crise, continuo não entendendo o papel que se quer que ela desempenhe. Eu cruzo uma avenida com sinal vermelho, o guarda apita e depois me multa (a mim e não a outrem). Como pode acontecer tudo aquilo se o que está em crise é a ideia do sujeito, a de signo e a de representação recíproca?" (ECO, 1984, p.149)
} 
humanista-iluminista são acolhidas ou rechaçadas. Isso tudo, é claro, sempre passando pela intervenção estilística e contaminação conceitual.

É verdade que, diante do atual declínio do político na esfera da cultura e da teoria, o engajamento oswaldiano pode soar anacrônico a alguns ouvidos. Até porque, para uma parcela influente do pensamento contemporâneo, a maior parte da discussão política do século passado é descartável hoje em dia, tendo em vista a hegemonia indiscutível do capitalismo liberal (que alguns chegam a presumir ter sido o efeito de um consenso espontâneo ou o desejo íntimo da maioria).

A ausência de concorrência parece fazer diminuir cada vez mais o interesse pela política e, consequentemente, inflacionar o terreno dos dilemas éticos. Terry Eagleton chamou a atenção para um certo puritanismo de doutrinas contemporâneas que negam qualquer valor a experiência comum e imediatamente acessível, em nome de gestos e intensidades no limiar do entendimento. Para muitos, atualmente, o que importa no homem é seu devir inumano. Diante disso:

a esfera da política é rebaixada para um status insipidamente utilitário e, como tal, é compreensivelmente difícil de se vincular a uma ética definida em contraposição a ela. Quanto mais degradado é o político, mais arrogante se afigura o ético. Que isso é efeito de uma certa história política, por si só, seria descartado como um juízo que não chega a ser propriamente ético(...)

Para Aristóteles, porém, a ideia de uma virtude não política seria difícil de apreender. Como seria possível avaliar qualidades de ação e caráter isoladas da polis que a produz? Um juízo que não levasse em conta essas condições não seria moral, mas moralista. (Eagleton, 2010, p.414-418).

A crença que dizia ser possível construir um mundo justo e que, portanto, deveríamos lutar pelo fim da dominação do homem pelo homem, adquiriu um status de lenda ingênua e alienante. Hoje em dia, as versões hegemônicas da verdade afirmam que a vida é um processo caótico, fragmentário e irracional, sobre o qual os homens não têm o menor controle. Logo, as tentativas de explicação desse processo rejeitam conceitos estáveis como o de sujeito, de autonomia, de humanidade, em nome de definições evasivas, labirínticas, céticas, cínicas, fatalistas, etc.; e que, em geral, chegam à conclusão de que não existem motivos para qualquer apreciação otimista da humanidade, nem se quer para se pensar em algo como a "humanidade". 
Ironicamente, porém, ao tentar fugir a qualquer custo das concepções modernas, de suas ficções metanarrativas, de suas noções ideológicas e da sua epistemologia "representativista", o pensamento pós-moderno não fez outra coisa senão reproduzir a ânsia iluminista pela neutralidade de julgamento e o desejo modernista pela expressão não-figurativa (não representacional).

Embora partilhemos a mesma realidade, em algum nível os fatos nunca falam por si e há sempre um processo deformador, marcado por uma inevitável parcialidade de quem os comunica. As fronteiras entre o descritivo e o argumentativo são sinuosas e imprecisas, o que faz com que muitas vezes tentativas genuínas de não ser ideológico, inadvertidamente, configurem a expressão precisa e bem acabada da ideologia dominante.

Oswald dizia que "todo romance é sempre um tratado de filosofia", pois "o papel do inconsciente é enorme"; mas "a cultura que não passa de censura é que dispõe da trama" (SR, 1991b, p.58).

Nos ensaios antropofágicos, ética e política não configuram esferas distintas, mas variações de pontos de vista sobre o mesmo objeto: o homem, a cultura, a natureza, as ideias. Em geral, a ética é abordada de um ângulo mais filosófico, mediante considerações acerca de crenças, desejos e valores; ao passo que a política é apresentada historicamente, nas análises das instituições e dos acontecimentos ao longo do tempo. Contudo, o embate entre matriarcado e patriarcado perpassa igualmente as questões sociais e subjetivas, alocando o problema em um confronto dinâmico entre visões de mundo, diferenças culturais e até inclinações sentimentais.

Oswald atribui um sentido à experiência que unifica política, psicologia, literatura, economia, direito, história e filosofia, numa deliberada mistura de canais entre hipótese e afirmação. Por conseguinte, conduz abertamente a questão dos fatos para o problema dos valores. E, sem dúvida, um dos principais valores que a Utopia de Oswald afirma é a velha ideia de que sociedades mais justas e menos autoritárias criam indivíduos mais livres e felizes.

Antônio Candido observou que Oswald jamais definiu formalmente o que é a antropofagia, mas apenas deixou “inúmeras pistas de alguns princípios 
virtuais" (Candido, 2006, p.58). Reunindo essas pistas, Benedito Nunes concluiu que, na filosofia antropofágica:

(...) a inquietação religiosa, completamente secularizada, converte-se na base impulsiva do ideal político de renovação da vida. Interioriza-se o estilo de ação militante, unindo, num mesmo ato de fé, a crença mítica no homem natural, fadado à liberdade, e a esperança de realização iminente, sempre possível porque utópica, do reino da justiça e de amor sobre a terra. Era um desfecho irônico, que contrariava a tão ambicionada serenidade filosófica formal. Sem o saber, Oswald atingia-lhe o avesso poético: esse outro lado da filosofia, que confina com o pensamento selvagem. Medida heterodoxa de uma inteligência afeita a teorizações esquemáticas, a Antropofagia selou a definitiva aliança entre o inconformismo político de Oswald de Andrade e o fundo religioso e místico do seu espírito. (Nunes, 1972, p. 57)

$\mathrm{Na}$ antropofagia, a diferença entre possível e impossível ou entre ficção e realidade, são pouco relevantes. Em consequência, certas conjecturas oswaldianas, simplesmente não podem ser levadas a sério. Algumas são infantis, outras totalizantes demais, outras demagógicas.

Por outro lado, alguns delírios do autor produzem o interessante efeito de nos fazer pensar sobre o aspecto fantasioso dos discursos que nos cercam com suas propostas de verdade e sensatez. Em particular aquele famoso delírio platônico, tão comum e repetido até hoje, que almeja uma unificada visão de mundo que incorpore os campos hostis da justiça, da realidade, da liberdade em uma fala coerente e de função prática. Caso contrário, deve-se descartar, por completo, como mentira.

A antropofagia não procura um perfeito discurso para uma perfeita república. Oswald se posiciona contra uma imagem abstrata de Estado patriarcal e contra os valores existenciais ligados a ele. Junto à liberdade, o que ele defende ardentemente é a felicidade, que não pode ocorrer senão como resultado de um bom e, muitas vezes, impensável encontro com o outro. Portanto, mais do que um projeto político, a Utopia antropofágica é uma crítica ideológica. 


\section{5 \\ Aspectos ideológicos da Reforma e da Contra-Reforma}

$\mathrm{Na}$ antropofagia ensaística, a oposição entre Reforma e Contra-Reforma vincula-se aos parentescos que ligam cada um dos movimentos às diretrizes patriarcais e matriarcais. Enquanto a Reforma, fundada sobre a cultura econômica da negação do ócio (negócio), surge como uma das derradeiras manifestações do individualismo patriarcal, a Contra-Reforma representa uma inusitada resistência das tendências coletivistas do ócio matriarcal.

Antes de ingressarmos nesse episódio particular do dualismo antropofágico, seria interessante, porém, recapitular alguns pontos do debate acerca do conceito de ideologia. Como vimos no capítulo anterior, a aderência oswaldiana às noções mais usuais de ideologia ${ }^{75}$, isto é, a de sistema de crenças e a de discurso de legitimação do poder de um grupo social dominante, é apenas parcial. Normalmente, seu pensamento perpassa essas acepções sem privilegiar nenhuma delas. $\mathrm{O}$ discurso ideológico é identificado tanto na alçada racionalmaterial quanto na irracional-libidinal.

Ocorre que, sob o pretexto da crítica à cultura messiânica do patriarcado, Oswald imprime uma série de deslocamentos de olhar sobre os temas em pauta. Conclui-se, a partir disso, que todo fenômeno histórico, incluindo a Reforma ou a Contra-Reforma, comporta variáveis matriarcais e patriarcais em si.

Não devemos nos deixar enganar pelo aparente proselitismo de suas reflexões. À medida que nos aprofundamos nelas o que sobressai é o constante

\footnotetext{
$75 \mathrm{Na}$ verdade, a variedade de acepções do conceito de ideologia só não é maior do que a bibliografia a respeito do termo. No livro Ideologia - uma introdução, Terry Eagleton argumenta que isso ocorre porque o termo tem uma série de definições convenientes, mas que nem todas são compatíveis entre si. Segue abaixo alguns dentre os vários exemplos mencionados por Eagleton (EAGLETON, 1997, p. 15):

1- O processo de produção de significados, signos e valores na vida social.

2- Um corpo de ideias característicos de um determinado grupo ou classe social.

3- Idéias falsas que ajudam a legitimar um poder político dominante.

4- Confusão entre realidade linguística e realidade fenomenal.

5- Conjuntura de discurso e poder.

6- Veículo pelo qual atores sociais conscientes entendem o seu mundo.

7- Pensamento de identidade.
} 
esforço dialético que não cessa de explorar as diferentes facetas de cada assunto. Como resultado, nas entrelinhas da investigação da história das ideologias, Oswald alimenta um debate sobre a própria noção de ideologia.

Sabemos que na teoria antropofágica a consciência se assenta numa dimensão irracional, uma "constante órfica" que, de resto, se traduz nos anseios e temores mais primitivos e na necessidade cega de crer, idealizar, fetichizar. O homem é "o animal fideísta, que crê e obedece (...)" e "que vive entre dois grandes brinquedos - o Amor onde ganha e a Morte onde perde" (CFM, 1972, p. 126).

Dessa concepção, se pressupõe não as usuais oposições entre objetividade e subjetividade, realidade e ficção, razão e fé, entre outras, mas uma continuidade: "O inexplicável para críticos, sociólogos e historiadores muitas vezes decorre deles ignorarem um sentimento que acompanha o homem em todas as idades e que chamamos de constante lúdica” (Ibidem).

Para lidar com essa conjectura, a crítica antropofágica apontará para diferentes estratos do discurso histórico, oscilando entre o exame mais usual e "iluminista", feito da perspectiva neutra e exterior ao objeto tratado; e a sondagem, digamos, mais "modernista", a partir do interior textual pela manipulação do estilo e por um questionamento indireto dos próprios procedimentos pelo qual se faz a crítica ${ }^{76}$.

Em consequência, sobrepõem-se nos ensaios análises macro e micropolíticas, diagnósticos materialistas e metafísicos, descrições líricas e anedóticas. Para Oswald, não só “o romance é sempre um tratado de filosofia, sem cátedra, sem terminologia especial e sem a responsabilidade de um sistema" (SR, 1991b, p.58); filósofos e cientistas também serão considerados poetas, romancistas e teólogos às suas maneiras.

$\mathrm{Na}$ filosofia antropofágica, qualquer temática ideológica, que inclui dilemas acerca da verdade, do poder, da liberdade etc., recebe tratamento incisivo, porém não conclusivo. Oswald não reproduz a postura normativa por ele

\footnotetext{
${ }^{76}$ A diferença entre os dois tipos de crítica (modernista e iluminista) é pormenorizada no ensaio "A época da crítica: Kant, Greenberg e o modernismo" de Antonio Cícero, no livro Finalidades sem fim. (CICERO, 2005)
} 
questionada. Seus ensaios se constroem de forma abertamente personalista: "Só o escritor interessado pode interessar" (DD, 1990, p. 86).

Por último, é sempre bom lembrar que o binarismo patriarcadomatriarcado é, acima de tudo, um esquema dialético. Ele funciona como um mapeamento geral, a partir do qual Oswald traça as linhas específicas de suas especulações sobre as contradições de uma situação essencialmente "órfica", de "pura devoração", em que não prevalece unidade sobre pluralidade de sentidos.

Com isso, as divisões abstratas do tempo, que normalmente determinam as várias épocas, estão sempre dialogando com as camadas mais profundas da história, responsáveis pela continuidade de significados que legitima a visão de mundo antropofágica. Nesse sentido, não obstante a explícita defesa da ContraReforma em face da Reforma, suas justificativas serão diversificadas e, muitas vezes, alheias aos problemas históricos e religiosos tradicionalmente reconhecidos.

É preciso desde logo compreender quão larga deve ser a concepção em que coloco como signo e bandeira a Contra-Reforma. Quando exalto os jesuítas, de modo algum assumo com eles um compromisso religioso ou ideológico. Entendendo como entendo o sentimento religioso universal a que chamo de sentimento órfico, o qual atinge e marca todos os povos civilizados como todos os agrupamentos primitivos, isso de nenhuma forma toca a minha equidistância, de qualquer culto ou religião (MU, 1972, p.152)

Para entendermos a concepção oswaldiana da Contra-Reforma, porém, devemos passar primeiro pelas reflexões acerca da Reforma.

Podemos começar observando que, apesar da provável influência do estudo clássico de Max Weber, a versão antropofágica se distancia significativamente dele não apenas no que tange à óbvia diferença de estilo e abordagem, mas também no que concerne aos objetivos e conclusões. Embora siga de perto alguns dos diagnósticos de Weber, Oswald não tem como meta uma investigação exaustiva da singularidade do fenômeno protestante dentro da história ocidental. Seu intuito é o de observar que papel cumpre a Reforma na dialética antropofágica, isto é, em que sentido ela dá continuidade às tensões entre patriarcado e matriarcado. 
Entretanto, mesmo correndo o risco de fugir um pouco à questão principal, creio que certos apontamentos sobre o estudo de Weber podem ser enriquecedores. Um bom exemplo disso se encontra logo na primeira parte de $A$ ética protestante e o espírito do capitalismo, que aborda o tema do controle sacerdotal sobre o imaginário e a vida cotidiana dos indivíduos, assunto de suma importância para a antropofagia. Afirma Weber que:

(...) cabe atentar aqui para o que hoje muitas vezes se esquece: a Reforma significou não tanto a eliminação da dominação eclesiástica sobre a vida de modo geral, quanto a substituição de sua forma vigente por uma outra (...).

A dominação do calvinismo tal como vigorou no século XVI em Genebra e na Escócia, na virada do século XVI para o século XVII em boa parte dos Países Baixos, no século XVII na Nova Inglaterra e por um tempo na própria Inglaterra seria para nós a forma simplesmente mais insuportável que poderia haver de controle eclesiástico do indivíduo.

Não um excesso, mas uma insuficiência de dominação eclesiástico-religiosa da vida era justamente o que aqueles reformadores, que surgiram nos países economicamente desenvolvidos, acharam de criticar (Weber, 2005, p. 31).

Na narrativa antropofágica, o evento Reforma coincide com um período de forte reação patriarcal à projeção do espírito matriarcal decorrente das grandes descobertas e revoluções culturais do século XVI. Defrontada com o pensamento europeu em ebulição, a mentalidade patriarcal teria respondido em igual medida, reformulando sua velha doutrina espiritual no intuito de fortalecer seu controle ideológico ameaçado pelos sopros libertários das descobertas científicas e da renascença, bem como pelas denúncias sociais das utopias humanistas e das guerras campesinas.

De onde poderia começar essa reformulação do patriarcado eclesiástico? Se a Renascença vai buscar inspiração na Grécia antiga, se o Humanismo se espelha no homem primitivo, a Reforma procura suas diretrizes ideológicas ali aonde, de acordo com Oswald, o cristianismo deixou para trás sua missão revolucionária e passou a servir às elites sacerdotais.

Inicialmente, resume à sua forma peculiar, o cristianismo foi proletário e tingido de revolucionarismo social. Diante da decadência do Império e em meio às discussões bizantinas em torno das teses messiânicas, a "Patrística conservou uma unidade polêmica favorável aos temas comunistas originados das seitas dos 
Essênios". Todavia, com Santo Agostinho surgiria a "Doutrina da graça", e com ela os caminhos para a salvação teriam se obscurecido.

Em Agostinho, o Sacerdócio retomara o seu papel de sentinela ativa do arbítrio. Só Deus escolhe, só Deus elege, só Deus salva. Ao lado disso, ele informa (por isso é Doutor) que só a Autoridade da Igreja faz crer em certos absurdos bíblicos. De modo que, em Agostinho se funda a doutrina da autoridade e do arbítrio que ia produzir, da Idade Média à Reforma, o esplendor do Sacerdócio Ocidental (...).( CFM, 1972, p.102).

Oswald encara a tese da eleição como um princípio excludente, típico do raciocínio sacerdotal messiânico e, consequentemente, anti-antropofágico. Recorrendo ao teólogo Karl Barth, ele ainda pondera que a transferência do caráter judaico de povo eleito para o de indivíduo começa, verdadeiramente, com São Paulo, que na Epístola aos Coríntios insiste "na qualidade de povo escolhido dos israelitas" e na Epístola aos Romanos informa sobre "os que Deus predestinou".

Porém, com Agostinho a lógica da predestinação "que grava a desigualdade humana diante dos arbítrios de Deus", teoricamente teria chegado a uma formulação mais radical, que proclamava a entrega ainda mais completa do indivíduo a Deus, expressa na máxima: "Diante desse divino Ser, todo outro ser é um ser que não é":

Essa dádiva espetacular, esse aniquilamento que parece reduzir a zero a personalidade é, no entanto, a insofismável e autêntica raiz do individualismo moderno, pois é a marca da própria eleição. Lutero dela se aproveitou à vontade. E foi o primeiro a denunciar a chantagem mística do culto católico. O enlevo dos sentidos, de que tanto os jesuítas se aproveitaram. (MU, 1972, p. 188)

A interpretação oswaldiana sobre as repercussões do resgate da "teoria da Graça" pela Reforma aponta para inúmeras direções caóticas. Até agora, nos concentramos apenas no suposto acréscimo de repressão religiosa que ela teria trazido às já abusivas prescrições de obediência da moralidade católica medieval.

Para Oswald, o resultado do resgate de uma doutrina que sanciona um grau ainda maior de mistério quanto ao arbítrio divino, só poderia significar que: "Deus 
pode fazer o que quiser. Para ele não há compreensão nem crítica. É a entrega pura e simples do escravo" (CFM, 1972, p.102)

Contudo, de modo paradoxal, a idéia de eleição também liberou imensamente a vida dos indivíduos de suas obrigações para com os dogmas romanos, desatando-o dos interesses imorais do clero. Ao propor o livre exame da Bíblia, Lutero irá de encontro aos cultos exteriores, aquele "enlevo dos sentidos" a que se refere Oswald na citação acima. A comunicação com Deus passa a dispensar as confrarias e peregrinações, o excesso de encenação e totemismo, para ser realizada de forma direta, sem a anuência sacerdotal obrigatória. Forjava-se ai um dos pilares para a construção do individualismo moderno.

Parecerá lógico a Oswald que o resgate da teoria da Graça ocorra nesse momento de convulsão social do século XVI. Segundo o autor, o episódio não foi diferente do que aconteceu com a decadência de Roma. Naquele período, transferiu-se à Igreja todo o prestigio do Império pela tese internacionalista da Cidade de Deus e pela tese aristocrática da eleição. Dessa vez, em meio as "Guerras camponesas" e as reivindicações parusaicas e milenaristas de Thomas Münzer, Lutero é quem ofereceria a saída conciliatória que dialogaria com toda estrutura óssea do Sacro Império Romano-Germânico.

Teoricamente, então, o roteiro teria se desenvolvido da seguinte forma: apoiadas nos velhos signos do cristianismo primitivo eclodiram as insurreições camponesas no norte da Europa (Suábia, Turíngia, Francônia). Alguns heréticos tentaram "restaurar as condições ideológicas que tinham saído do apostolado de Pedro e de Paulo, bem como a existência das primeiras comunidades cristãs". (OA, 1991, p.256). Entre eles, destacam-se Münzer (inicialmente parceiro de Lutero) e seus rebelados, que exigiam justiça em vida e, para isso, atacavam não apenas a aristocracia eclesiástica, mas a propriedade privada, a nobreza feudal e os príncipes ${ }^{77}$.

\footnotetext{
${ }^{77}$ No livro As Guerras Camponesas, Engels explica que tudo aquilo que se chama de guerras religiosas do século XVI, tinham no fundo interesses sociais (materiais, de classe) muito positivos. No entanto, diante da posição singular de supremacia da Igreja como símbolo e sanção da ordem feudal, é evidente que todo o ataque feito ao feudalismo devia primeiramente dirigir-se contra a Igreja. "e que todas as doutrinas revolucionárias, sociais e políticas deveriam ser em primeiro lugar heresias teológicas. Para poder trocar a ordem social existente era necessário despojar sua aureola" (ENGELS, 1971, p.35) Oswald se estende sobre esse tema. Embora concorde com Engels, lamenta que seu livro seja "atravessado pelo velho esquema metodológico marxista, que se ressente dessa
} 
No entanto, "todo o fruto de suas penosas e sangrentas campanhas foi colhido por um monge oportunista, cujo único mérito é o de ter limitado ainda mais o poderio do Papado, retirando de suas garras a mais rica e poderosa metade da Europa" (OA, 1991, p.256). Se, por um lado, Lutero vociferava contra a "Sodoma romana", por outro acalentava os interesses da aristocracia com sua "moderação calculada" (MU, 1972, p.186.) Para ele, o Papa deveria ser destruído pela palavra, e por isso não hesitou em dar as costas a Münzer e em dialogar com as classes dominantes, quando estas se viram ameaçadas em suas posses.

Note-se, de passagem, como a religião por si só, não é refutada por Oswald. O misticismo revolucionário de Münzer é visto até com grande simpatia por ele. Simpatia que ele estende à corrente que, a seu ver, se prolonga por Jacob Böheim, Mestre Eckhart, chegando aos intuitivos, ateus ou não, do Sturm und Drung e do Romantismo, pois segundo o autor: "para os grandes místicos, o Messianismo é assunto de portas fechadas, e, portanto, assunto que dispensa o sacerdócio", (CFM, 1972, p.104)

Diferente de Münzer, entretanto, Lutero não estava interessado em fechar suas portas. Ele entendia que a grande crise do sacerdócio romano era diretamente proporcional ao florescimento da burguesia. Foi o dinheiro dela que embaralhou as hierarquias, expandiu e impôs o valor econômico sobre todos os outros. Através dele estouraria de vez a corrupção da venda de indulgências e ficaria explícito o antro de torpeza em que se transformara Roma.

Diante desse cenário, a Reforma irá se apossar de vastos e ricos territórios, habitados por alguns dos povos mais cultos da Europa. Nas contas de Oswald, eleição, individualismo e capitalismo iriam se dar as mãos na negação do ócio.

O negócio é a imoralidade fecunda. Da insensibilidade dos precursores do capitalismo vai sair a força terrena da revolução industrial. Eis como Lutero define o seu próprio estado de eleição: "Um dia Deus se voltará para nós sorrindo e nos ornará com uma coroa imarcescível dizendo: Confessaste que eu era senhor, pregaste meu nome. Muito bem! Que foste pecador, pouco importa, basta teres

obsessão - tudo nele é luta de classes e somente luta de classes. Não existe outro fator que possa ter influído no movimento munzeriano" (MU, 1972, p185). Para ele outras questões contribuíram para o clima favorável a Reforma. Como, por exemplo, o fato de a Igreja não ter conseguido sua unificação na crise do século XIII, principalmente pela "influência temperamental de Frederico II e da sua formação sarracena nesses longínquos, mas decisivos acontecimentos” (MU, 1972, p. $185)$. 
acreditado em mim e me conferido toda a honra. Assim, testemunharei por vós perante meu Pai Celeste".

Como se vê, é um contrato a que somente falta a confirmação tabelioa. O espírito da transação burguesa está todo na Reforma. (CFM, 1972, p.108)

A queda da hegemonia do pensamento católico medieval está ligada a uma constelação de acontecimentos históricos interdependentes: a descoberta do Novo Mundo, o Humanismo, a Renascença, a Nova Ciência, a ascensão burguesa, as Guerras Camponesas, a Reforma, etc. Nem todos esses fenômenos se desenvolveram a partir de propósitos coletivistas. Alguns, ao contrário, semeavam as bases do individualismo moderno. Foi assim que, em meio às agitações do século XVI, reformadores e burgueses se associaram, revigorando os ideais patriarcais da propriedade, da herança e do trabalho.

As páginas em que Oswald descreve a crise do papado romano e da ascendência burguesa são dignas do que há de melhor na antropofagia ensaística. Todavia, são longas e abundantes. O excerto que segue, portanto, é apenas uma amostra dos vários parágrafos nos quais o autor retrata a aurora do capitalismo moderno.

Numa gigantesca operação de estorno ideológico o que agora se procura é o êxito na terra. $\mathrm{O}$ triunfo no céu importa menos que a moeda à vista, sonante e boa (...). A cidade, face ao castelo, é o segredo da transformação diabólica do mundo. A cidade é o mercado, a cidade é o desejo que estimula a produção. $O$ burguês não se tornara ainda o explorador genialmente descrito pelo romancista Marx. Ele é o inimigo número um da servidão do campo. "O ar do burgo produz liberdade" diz um provérbio alemão da época. A cidade traz no seu bojo o banco e o empréstimo. O senhor feudal que conserva a economia de Deus, naufraga na dívida, filha dileta da prodigalidade. Na cidade, o burguês economiza. O dinheiro é o agente anônimo de sua força. Junto com a pólvora ele destrói as muralhas onde se açoita impotente, o senhor do latifúndio (...). O homem comum pode agora ser alguém. Dispensa os privilégios que destacavam no fundo amargo das explorações medievais, o barão feudal. (CFM, 1972, p.106)

Apesar do abalo que causa nos privilégios do sacerdócio e nobreza medievais, a burguesia logo se arma de garantias patriarcais. Ela instaura a família monogâmica em contraposição à bastardia do castelo, bem como revigora o direito romano, que garante a propriedade privada e a herança, além de tutelar a mulher. No passado, diz Oswald, ela se vingou: "De uma só vez, na Roma da gens 
patriarcal, tinham sido condenadas à morte cento e setenta esposas por envenenamento dos maridos". Agora, sob a ordem burguesa, atenua-se o conflito: "Engels afirma que o casamento monogâmico vive sobre duas muletas - o adultério e a prostituição" (CFM, 1972. P.107).

A Reforma, então, ajuda a criar as bases morais para a ação burguesa. Lutero traduz a Bíblia, fomentando a livre interpretação pelo acesso direto à palavra divina. Além disso, liquida o celibato: "O sacerdote perde ai a sua vestalidade. Passa a ser o homem sem mistério, o homem devassado pela intimidade da família.” (CFM, 1972, p. 107). Enfim, a Igreja perde o monopólio de decisão sobre quem vai para o céu e quem desce para o inferno. Dali por diante, só os desígnios misteriosos da graça é que contam. A eleição, porém, começa a mostrar à que veio:

\begin{abstract}
A prosperidade nos negócios é um sinal da eleição. O pastor tornou-se apenas um conselheiro pois que, por obra da graça, qualquer espertalhão pode ter o céu garantido. As seitas dividem-se, subdividem-se à vontade dos grupos. E cada um pode ter suas preferências de culto.

Cai das mãos do sacerdote o poder de julgar e condenar. Transferida a grande instância para Deus, tudo passa a ser caso de consciência. Qualquer mortal faz suas contas com o próprio Deus. E isso desentrava as iniciativas do capitalismo que prospera nos países reformados portadores de matéria-prima. $\mathrm{O}$ anglicanismo é uma teologia do tecido, depois do carvão. É possível arrancar a mais valia do proletariado indefeso que nasce, sem quebra de moralidade (CFM, 1972, p.110111)
\end{abstract}

Não deixa de ser curioso perceber o leve tom queixoso na narrativa da decadência do catolicismo que, em outros momentos, merece toda a ferocidade oswaldiana. É que, em face da mentalidade protestante, ele constatava que "com todas as suas tropelias e seus erros, a corrupção romana, a tirania apostólica, a venda de indulgências, o catolicismo conserva a linha tomista que traz em si, além da sociologia da esmola, um vago perfume de coletivismo" (CFM, 1972, p.105)

Vimos no capítulo anterior como Oswald aspira revelar o aspecto coletivista da Idade Média, que tem no "justo preço" típico da "economia do ser", um dos índices matriarcais. Segundo ele, no espírito desprevenido de “compagnonnage", conta a lenda que um cavaleiro após ser acusado de depredar um terceiro, declarara: “NNão é pra mim e sim para dar aos outros’. E realmente 
dava. Porque o código de honra que presidiu aos primórdios dessa época baseavase em valores outros do que os que fizeram a economia do haver" (OA, 1991, p.266).

Afora os idealismos oswaldianos, sem dúvida, um dos principais feitos da Reforma foi ter desonerado os indivíduos de certos tradicionalismos medievais que prescreviam a vida pródiga, a repreensão à usura, ao lucro exagerado e ao ganho com juros. Essa desoneração moral propiciou a adesão de vários pequenos e médios produtores a certas formas nascentes de racionalização dos negócios. Em paralelo, a Reforma forjava a identificação direta entre ofício e vocação, a partir da qual se inverteu a lógica que enxergava no trabalho um meio para a vida, e não um fim, pelo qual se verificava a eleição de alguém ${ }^{78}$. Oswald diagnostica, nessa mudança de raciocínio, a inserção inconsciente do que chamava de "psicose do lucro".

Talvez o exemplo mais célebre dessa inversão ideológica se encontre no famoso discurso de Benjamin Franklin, no qual inaugura a moral do "time is money" e defende a associação entre ascese e poupança. Na versão oswaldiana, esse discurso ganha a seguinte cara: "Se amas a vida, não percas tempo, pois, que o tempo é a substância da vida. Que tempo inútil gastamos em dormir, esquecendo que a raposa que dorme não pega galinhas e que no túmulo, teremos tempo de dormir por toda a eternidade" (CFM, 1972, p.105).

Como se sabe, Max Weber analisa o discurso de Franklin em pormenores. Uma de suas conclusões é que:

Uma disposição como a que se expressa nas passagens citadas de Benjamin Franklin e que obteve o aplauso de todo um povo teria sido proscrita tanto na Antiguidade quanto na Idade Média, tanto como expressão da mais sórdida avareza quanto como uma disposição simplesmente indigna, e ainda hoje essa

\footnotetext{
${ }^{78}$ No livro Historia econômica general, afirma Weber: "O calvinismo não admitia a evasão do mundo e sim, considerava como missão religiosa de cada indivíduo a colaboração no domínio racional do universo. Deste critério deriva nossa atual palavra "profissão" (no sentido de "vocação"), que só conhecem os idiomas com influência da tradução protestante da Bíblia. Esse termo expressa a valorização da atividade lucrativa capitalista, baseada em fundamentos racionais como a realização de um objeto fixado por Deus" (WEBER, 1961, p.378).

Em A ética protestante e o espírito do capitalismo o conceito de vocação é definido da seguinte forma: "Assim como o significado da palavra, assim também a ideia é nova e é um produto da Reforma: a valorização do cumprimento do dever no seio das profissões mundanas como o mais excelso conteúdo que a auto-realização moral é capaz de assumir (...) uma significação religiosa do trabalho mundano de todo dia" (WEBER, 2005, p.72)
} 
suspeita normalmente se verifica entre aqueles grupos sociais menos envolvidos na economia capitalista especificamente moderna ou a ela menos adaptados (Weber, 2005, p. 49)

Obviamente a ganância não é uma invenção do capitalismo moderno nem da Reforma. Longe disso, "a auri sacra fames é tão velha quanto a história da humanidade" (Weber, 2005, p.50). Entretanto, o que Weber identifica como o "espírito do capitalismo" moderno, que para ele só foi possível mediante uma reeducação religiosa, é a motivação ilógica, do ponto de vista eudemonista e hedonista, de uma "conduta de vida em que o ser humano existe para o seu negócio e não o contrário" (Weber, 2005, p.62), uma espécie de irracional sensação de cumprimento de dever forjada nos meandros das inúmeras versões da doutrina de eleição que cresceram principalmente da raiz anglicana puritana do protestantismo.

Ou seja, mais do que a ambição e a riqueza, que até foram bastante condenadas entre várias seitas puritanas, fazendo com quê, ironicamente, alguns dos efeitos culturais da Reforma tenham sido resultados indesejados do trabalho dos reformadores; enfim, mais do que o acúmulo, o que estava em jogo na "psicose do lucro" era a condenação moral do "descanso sobre a posse e do gozo da riqueza com sua consequência de ócio e prazer. 'O descanso eterno dos santos está no Outro Mundo'. A perda de tempo é, assim, o primeiro e em princípio o mais grave de todos os pecados" (Weber, 2005, p.143). A falta de sentido dessa acumulação pela acumulação foi ironicamente definida por Bertrand Russel da seguinte forma: "afirmar que ganhar dinheiro é bom, mas gastá-lo é ruim equivale a dizer que chaves, às vezes são boas, mas as fechaduras não o são" (Russel, 1956, p.10).

Percebe-se que o tipo de cupidez e cobiça que caracterizaram mercadores, sacerdotes e príncipes em toda a história "pré-capitalista", na verdade, foram incômodos entraves para a disseminação generalizada do "espírito capitalista" moderno, tal como Weber o descreve. Isso explica, inclusive, porque boa parte das regiões católicas que mantiveram a mentalidade feudal de ócio, rendas e honrarias viram frear seu surto capitalista inicial. A outra parte, que Oswald nomeia de "abstencionistas", criou, pela 
livre concorrência, a época da acumulação fornecendo "o alimento vertiginoso dos futuros parques de transformação da lã que faria com que Marx chamasse a essa época o tempo em que os carneiros devoravam os homens" (...) (CD, 1991, p.210)

A estreita ligação entre ascese e capitalismo, que para Weber é o ponto chave da revolução gerada pela Reforma, em Oswald ganha um enfoque diferente. $\mathrm{Na}$ sua avaliação, esse problema específico situa-se no enquadramento mais amplo da dialética da "cultura da escravidão" e da "cultura antropofágica".

É dessa ótica que a antropofagia questiona o discurso moral que prescreve com naturalidade o modo de vida capitalista moderno. Para Oswald, porém, não há nada de natural na ética do "time is money" como valor supremo, como sinal da própria "graça" divina. Contrariamente, ele reforça as teorias de que essa mentalidade é relativamente recente na história da humanidade. Na Grécia antiga, por exemplo, recomendava-se o ócio como pré-requisito indispensável para o autoconhecimento $^{79}$ e o autogoverno. Entre os orientais, a contemplação e a relação desacelerada com o tempo sempre esteve intimamente ligada à sabedoria. No medievo, como vimos, certas prescrições puritanas seriam vistas como sinônimo de usura e mesquinhez. Para os povos primitivos, provavelmente, elas aparentariam algo próximo da loucura. Oswald planeja, desse modo, mostrar que "esse postulado ignora que é efêmero no tempo, pois supõe ser da própria natureza do homem suar e penar como fora determinado por Deus a Adão na expulsão do paraíso ocioso para o qual parecia ter sido criado.” (MU, 1972, p.157).

A "cultura do ócio", como praticamente todos os conceitos da antropofagia, não deve ser levada ao pé da letra, mas antes no seu aspecto metafórico. No contexto da dialética Reforma x Contra-reforma, a noção de ócio matriarcal age como uma alegoria negativa, uma espécie de oposição franca ao status quo capitalista, na forma em que se apresentava nos anos 1940-50. Assim, o pouco sutil antagonismo ócio $\mathrm{x}$ escravidão funciona também como uma provocação crítica, um alargamento do nosso imaginário em face das sanções ideológicas a que é submetido. Em outras palavras, Oswald investe numa descrição re-moduladora do nosso sistema de valores, re-embaralhando as cartas

\footnotetext{
${ }^{79}$ Oswald lembra que a origem etimológica grega da palavra ócio é scholé, donde se deriva escola. (CFM, 1972, p. 13)
} 
morais que têm a pretensão de fixar as necessidades, os objetivos e o sentido de algo tão indeterminado como a vida humana.

Dito isso, chegamos a um dos pontos mais desconcertantes da narrativa argumentativa de Oswald, que é justamente a reabilitação da Contra-Reforma, três décadas após tê-la alvejado no Manifesto Antropofágico ${ }^{80}$.

Antes, porém, é forçoso lembrar que nesse espaço de tempo surgiriam duas obras que influenciaram enormemente a visão dos estudiosos sobre os atores envolvidos no processo colonial brasileiro. São elas: Casa Grande e Senzala e Raízes do Brasil.

O impacto que os dois livros tiveram no meio intelectual brasileiro da década de 30 em diante ${ }^{81}$ - e a determinante influência que exerceram sobre Oswald - é decisivo em vários sentidos. Eles traziam a denuncia de racismos latentes e a desmistificação de fundamentos patriarcais na retórica acadêmica. Além disso, inauguravam estilos completamente novos de fazer teoria social. Gilberto Freyre, com sua escrita original, profusa em imagens, inundada de informações. Sérgio Buarque, com sua profundidade sintética, mas de igual poder descortinador.

É verdade que os dois autores representam movimentos diferentes. Como explica Renato Ortiz, Sergio Buarque está ligado a uma nova linhagem que busca entender pelas técnicas e regras específicas do universo acadêmico a realidade brasileira. Ao passo que Gilberto Freyre representa, de certa forma, uma

\footnotetext{
${ }^{80}$ Do Manifesto: "Contra a verdade dos povos missionários, definida pela sagacidade de um antropófago, o Visconde de Cairu: - É mentira muitas vezes repetida" (ANDRADE, 1972, p.17) "Contra o Padre Vieira. Autor do nosso primeiro empréstimo, para ganhar comissão. O reianalfabeto dissera-lhe: ponha isso no papel mas sem muita lábia. Fez-se o empréstimo. Gravou-se o açúcar brasileiro. Viera deixou o dinheiro em Portugal e nos trouxe a lábia. (ANDRADE, 1972, p.15)

${ }^{81}$ No prefácio de Raízes do Brasil Antonio Candido comenta a repercussão desses livros. Sobre Casa Grande e Senzala, diz que: "O jovem leitor de hoje não poderá talvez compreender, sobretudo em face dos rumos tomados posteriormente pelo seu autor, a força revolucionária, o impacto libertador que teve este grande livro. Inclusive pelo volume de informação, resultante da técnica expositiva, a cujo bombardeio as noções iam brotando como numa improvisação de talento, que coordenava os dados conforme pontos de vista totalmente novos no Brasil de então" (CANDIDO Apud HOLANDA, 1995, p. 10)

Sobre Sergio Buarque de Hollanda e Raízes do Brasil, diz que: "Talvez tenha sido ele o primeiro pensador brasileiro que abandonou a posição "ilustrada", segundo a qual cabe a esclarecidos intelectuais, políticos, governantes administrar os interesses e orientar a ação do povo. Há meio século, neste livro, Sérgio deixou claro que só o próprio povo, tomando iniciativa, poderia cuidar do seu destino." (CANDIDO Apud HOLANDA, 1995, p. 23)
} 
continuidade, isto é, "uma reinterpretação da problemática proposta pelos intelectuais do final do século (XIX)" (Ortiz, 2001, p. 40).

Creio, no entanto, que para o Oswald de Andrade de 1945 em diante esses detalhes eram menos importantes do que a indiscutível qualidade analítica e literária dos dois livros, bem como a forma pela qual circulam de modo indiscernível a informação objetiva e a coragem subjetivista, típica dos grandes autores.

Sobre Freyre, Oswald tece incontáveis elogios em artigos de jornais (pósmilitância comunista). Em particular, na crônica intitulada Por Gilberto, escrita no Correio da Manhã em 1946, expõe de forma cristalina a importância da obra do sociólogo para a concepção ensaística da antropofagia que começava a ser arquitetada naquele momento:

\begin{abstract}
Anuncia-se um movimento pela candidatura de Gilberto Freyre ao prêmio Nobel de literatura. Não faltam opositores a essa reivindicação que pretende colocar o Brasil oficialmente entre os países de alto nível intelectual. Dizem esses homens de má vontade que Gilberto não é ficcionista e que o prêmio visado se destina somente aos criadores de literatura. Será, no entanto, outra coisa do que uma criação, "Casa Grande e Senzala", esse marco da nossa avançada posição mental tão distante da posição econômica, moral e política em que vegetamos?

Se há ainda alguma coisa que salva este país, é a literatura. E a obra-prima de Gilberto transcende da sociologia e da crítica para esplender nisso que se pode moderna e realmente chamar de literatura.

Quando eu era comunista de varal, fiz todas as restrições canônicas ao livro de Gilberto. Achei-o hesitante, não concludente, semi-visionário, semi-reacionário e classifiquei-o de joia da sociologia afetiva. Minha experiência pessoal me conduziu agora a crer, com o admirável Camus, que nada há de mais odioso que o pensamento satisfeito e a obra que prova. Nada mais odioso que a tese na obra de arte (TEL, 1996, p.200-201)
\end{abstract}

A crônica desfia com rara clareza a posição de Oswald diante da suposta neutralidade e cientificidade de sociólogos, historiadores, etc. Vemos o quão essencial para ele era o atravessamento da criação nas ciências humanas, sob o risco de se fazer "literatura dirigida" e "literatura de tese". Em sua opinião, Casa grande e senzala retomava o olhar de deslumbramento dos primeiros cronistas e afastava-se da ingenuidade dos relatórios e da "etnologia de barba" de europeus como Max Schmidt e Karl Von den Stein, autores de importantes obras sobre os índios brasileiros. Enfim, era "um livro totêmico e raro". 
No que diz respeito a Sergio Buarque de Holanda, o diálogo fica manifesto na famosa palestra/ensaio intitulada: Um aspecto antropofágico da cultura brasileira: o homem cordial, na qual são traçados paralelos entre as duas teorias.

$\mathrm{O}$ "homem cordial" refletia em minúcias algumas das características mais marcantes da cultura matriarcal. Sérgio Buarque, por exemplo, dizia que a cordialidade era o contrário da polidez e das boas maneiras, e que era a expressão de um fundo emotivo transbordante, oriundo de "uma verdadeira libertação do pavor que ele sente em viver consigo mesmo, em apoiar-se em si próprio em todas as circunstâncias da existência (...). Ela é, antes, um viver nos outros" (Holanda apud Andrade, AHC, 1972, p. 142). Para Oswald, estes eram claros sinais matriarcais relativos à importância que o comunial adquiria na cosmologia antropofágica do primitivo. "A periculosidade do mundo, a convicção da ausência de qualquer socorro supraterreno, produz o "Homem cordial", que é o primitivo, bem como suas derivações no Brasil” (AHC, 1972, p.143).

Apesar dessas determinantes afinidades teóricas, me parece, todavia, que a maior contribuição recebida por Oswald dos dois autores se vincula aos estudos sobre as origens do povo português e sua influência na colonização. Nos textos de antropofagia filosófica emerge um Oswald diferente, entusiasta das nossas raízes ibéricas, principalmente no que se refere à formação mestiça e cosmopolita de Portugal, apontada em detalhes tanto por Freyre quanto por Sergio Buarque ${ }^{82}$.

Assim, se na época do manifesto, em 1928, os jesuítas pareciam ter “deixado entre nós uma psique neurastênica” (DD, 1990 p.50), agora eram vistos como uma continuidade da cultura árabe e de seus valores exogâmicos e aventureiros. Isso explicaria seu suposto desapego em relação às questões raciais e

\footnotetext{
${ }^{82}$ São abundantes as análises desse aspecto da formação portuguesa nos dois autores, cito dois curtos exemplos, um de cada autor, apenas como curiosidade:

Sergio Buarque: "Cumpre acrescentar outra face bem típica de sua extraordinária plasticidade social: a ausência completa, ou praticamente completa, entre eles, de qualquer orgulho de raça. Ao menos do orgulho obstinado e inimigo de compromissos, que caracteriza os povos do Norte. Essa modalidade de seu caráter, que os aproxima das outras nações de estirpe latina e, mais do que delas, dos mulçulmanos da África, explica-se muito pelo fato de serem os portugueses, em parte, e já ao tempo do descobrimento do Brasil, um povo de mestiços". (HOLANDA, 1995, p.53)

Gilberto Freyre: "Os que dividem Portugal em dois, um louro, que seria aristocrático, e outro moreno ou negróide, que seria o plebeu, ignoram o verdadeiro sentido da formação portuguesa. (...) o estado de conquista e reconquista, de fluxo e refluxo, não deixou que se estabelecesse em Portugal nenhuma hegemonia a não ser de momento. Nenhum exclusivismo - a não ser oficial ou superficial - de raça ou cultura" (FREYRE, 1977, p. 256).
} 
culturais, e ao mesmo tempo seu fervor religioso. Oswald liga os fundamentos escolásticos da Contra-Reforma ao aristotelismo de Averrois, afirmando a existência de um islamismo subjacente à ideologia Inaciana:

Já que se profanou e corrompeu a catolicidade medioeva, os jesuítas empalmam a perdida missão ecumênica da Igreja. Uma diferença os marca. Eles são os maometanos de Cristo. Entra na sua arrancada um fogo estranho que não dissimula raízes árabes. É a disciplina, a tenacidade mística, a entrega do perinde ac cadáver $^{83}$, desconhecidas do primeiro cristianismo como do alto Papado. Há uma espécie de tara cultural que reaparece no cerne de sua vocação teocêntrica. Sob os disfarces escolásticos dir-se-ia que Averrois lança da Córdoba islamita, a voz renovada de Aristóteles. É tão grande a ausência de "estado de graça" que mais tarde quando o Marquês de Pombal vai iniciar a expulsão de suas hostes das cortes da Europa, pode acusá-los de "ateísmo" (...) (AI, 1972, p.37-38).

O elogio da Contra-reforma, sem dúvida, traz à tona a faceta mais etnocêntrica da antropofagia ensaística. Há um certo exagero na exaltação do expansionismo muçulmano e de sua organização guerreira, frutos do "idealismo residual e violento" e da "paixão árabe que tanto influiria nos nossos costumes". (AI, 1972. P.38).

Será mais seguro, portanto, seguir o pensamento de Oswald tendo em mente que ele escreve suas teses na década seguinte ao fim da Segunda Guerra Mundial. Na ocasião, o principal rival do estilo de vida ocidental era a "ameaça comunista". Ademais, o racismo nazista e o totalitarismo fascista eram recentes na imaginação de todos, além do que, mantinham alguns traços persistentes em ditaduras de esquerda e de direita.

É nesse ambiente que Oswald exalta o caráter mestiço, cosmopolita e tolerante das civilizações mediterrâneas que cresceram sob o domínio árabe em contraposição à cartilha civilizatória das culturas "exclusivistas" do Ocidente setentrional. Como de costume, a especulação vai longe e pressupõe uma bifurcação semita que, de um lado teria dado o Islã, exogâmico e mesclado e, de outro, a cultura fechada e endógama dos judeus. Esta, tragicamente, os teria levado ao seu maior adversário - Hitler. "O Fuehrer vem direitinho do masaísmo e constitui, sem dúvida, a mais dramática lição que receberam os exclusivistas

\footnotetext{
${ }^{83}$ Perinde ac cadáver: "Bem disciplinado como um cadáver" nas palavras de Santo Inácio.
} 
defensores do privilégio de raça, país e religião" (MU, 1972, p.148). Oswald traça o seguinte trajeto:

Pode-se ligar isso ao fenômeno que na alta antiguidade dividiu os semitas. Os judeus, julgando-se povo eleito, detentor exclusivo dos favores de Deus, criaram o racismo. Os árabes, povo exogâmico, aberto para as aventuras do mar e para o contato exterior criaram a miscigenação. E a luta desenvolvida por milênios, tanto no campo ético como no campo cultural, foi essa - entre o racismo esterilizador mas dominante dos judeus e a mistura fecunda e absorvente dos árabes. Aqueles deram longinquamente a Reforma, estes a Contra-Reforma. Aqueles produziram Lutero e Calvino, enquanto estes, os jesuítas, que foram feridos pelo Vaticano na sua plasticidade política, filha da miscigenação da cultura que adotavam (MU, 1972, p.148).

Seguindo essa lógica, a Guerra Holandesa será interpretada como o marco moderno do antagonismo histórico descrito acima. Ela servirá, igualmente, como principal cenário para a defesa da Contra-Reforma. De acordo com a narrativa oswaldiana, essa guerra esquecida numa esquina abandonada da história, teria prenunciado as tensões do mundo pós-Guerra. Assim, quando os brasileiros expulsaram os holandeses do nordeste brasileiro, subliminarmente a Contrareforma dava um recado à mundialmente vitoriosa Reforma: era a primeira batalha do "pré-socialismo" contra o "pré-capitalismo", numa "luta que até os nossos dias prossegue sob dissimulações, transferências e disfarces, mas que constitui a espinha dorsal de todo um sistema histórico e filosófico" (MU, 1972, p. 178).

A antropofagia filosófica, no entanto, está longe de ser uma simples ramificação do marxismo. Afinal de contas, Oswald está defendendo a Companhia de Jesus. E, se é verdade que o faz encantado pelas reduções Jesuíticas que levaram a República Comunista Cristã dos Guaranis, ("glorioso e incompreendido cometimento social e humano") (Ibidem.), sua exaltação da Contra-Reforma se pauta em razões mais amplas.

Segundo Oswald, algo além do confronto entre dois modelos de colonialismo deve ter influenciado na vitoria de um povo com inferioridade técnica e militar. As explicações tradicionais costumam apontar para as dificuldades fonéticas praticamente insuperáveis entre a língua holandesa e os idiomas indígenas e africanos (problema enfrentado em bem menor escala pelo 
português e pelo castelhano). Ele não discorda, mas acrescenta: "a língua era a comunicação. E além do mais, essa língua áspera de fora era o instrumento de uma ideologia mais áspera ainda - a da Reforma.” (MU, 1972, p.180).

Sem dúvida, durante os séculos de contato entre índios e europeus, código linguístico e código religioso coincidiram. A língua servia fundamentalmente para transmitir a cosmologia religiosa de cada povo. E o europeu percebeu rapidamente que não seria possível impor sua língua sem impor sua religião. "Instituir o nome de Deus equivale a impor o código linguístico no qual seu nome circula em evidente transparência" (Santiago, 2000, p.13), lembrou Silviano Santiago, a respeito do trabalho de jesuítas e colonizadores a partir da segunda metade do século XVI. Um clássico exemplo são os autos de José de Anchieta. As peças bilíngues do jesuíta exerceram um papel auxiliar, por meio de uma ação lúdica e didática, no trabalho de substituição do sistema sagrado e da língua indígena.

Oswald recorre, então, a Sergio Buarque para dar continuidade à argumentação:

Diz o sociólogo brasileiro: "ao oposto do catolicismo, a religião reformada, trazida pelos colonizadores, não oferecia nenhuma espécie de excitação aos sentidos ou a imaginação dessa gente e assim não proporcionava nenhum terreno de transição por onde sua religiosidade pudesse se acomodar aos ideais cristãos". E acrescenta: "O que parece ter faltado em tais contatos foi a simpatia transigente e comunicativa que a Igreja Católica, sem dúvida mais universalista ou menos exclusivista do que o Protestantismo, sabe infundir nos homens (MU, 1972, p.180)

Para Oswald, o sociólogo se esquece de frisar que quem trouxe o catolicismo para o Novo Mundo foi a "ordem plástica e compreensiva" dos jesuítas, que através de suas liturgias e de sua utópica missão catequizadora, buscaram transformar o Brasil no paraíso perdido.

Com isso, ele não chega a negligenciar a primeira fase inclemente da colonização, na qual a política jesuíta de catequização realizada por Mem de Sá, Manuel da Nóbrega, o próprio José de Anchieta e outros, serviu como coadjuvante no extermínio de milhares de índios na costa brasileira do século XVI, sem grandes escrúpulos humanitários. Nessa fase, os jesuítas, assim como todas as outras ordens religiosas, funcionaram como amansadores de nativos, 
minando suas lealdades étnicas e vitimando-os com suas doenças e pragas européias. Por essa razão, ele cita o livro A Conquista Espiritual, do jesuíta Montoya $^{84}$, para dar uma medida geral da corrupção impingida pelos conquistadores aos índios. Mediante a tradução dos mandamentos da lei de Deus para língua autóctone, os jesuítas teriam imposto a ideia dos pecados mortais de desejar a mulher do próximo e desrespeitar o domingo àqueles que "desconheciam a mulher do próximo e tinham não o dia do ócio, mas o ano do ócio" (OA, 1991, p.283). Mais a frente, reproduz o caso relatado pelo missionário Claude d'Abbeville ${ }^{85}$ no livro História da Missão dos Padres Capuchinhos na ilha do Maranhão, no qual um chefe índio matara a mulher ao pegá-la em adultério. "Como se visse cercado por ordem dos brancos, Japuy-nassu penetrou na capela da aldeia, de onde trovejou contra os catequistas que mandavam castigar o adultério e queriam depois puni-lo por obedecer a seus preceitos" (Ibidem).

No século seguinte, contudo, a Companhia parece ter mudado um pouco seu papel. Segundo Darcy Ribeiro, "representados por figuras mais capazes de indignação moral, como Antônio Vieira" (Ribeiro, 2008, p.56) alguns jesuítas, de fato, se posicionaram na defesa dos nativos. Como ilustração do rumo tomado pelo empreendimento a essa altura, cito uma passagem do livro $O$ povo brasileiro que surpreende por confirmar muitas das descrições antropofágicas:

\begin{abstract}
A tarefa a que os missionários se propunham não era transplantar os modos europeus de ser e de viver para o Novo Mundo. Era, ao contrário, recriar aqui o humano, desenvolvendo suas melhores potencialidades, para implantar, afinal, uma sociedade solidária, igualitária, orante e pia, nas bases sonhadas pelos profetas. Essa utopia socialista e seráfica floresce nas Américas, recorrendo às tradições do cristianismo primitivo e às mais generosas profecias messiânicas. Ela se funda, por igual, no pasmo dos missionários diante da inocência adâmica e do solidarismo edênico que se capacitaram a ver nos índios, à medida que com eles conviviam (...)

(...) Sonham ordenar a vida indígena segundo as regras da Utopia, de Morus, inspirados anacronicamente na indianidade original. Acreditaram mesmo que era possível abrir essa alternativa para a conquista, fazendo da expansão européia a universalização da cristandade. Encarnada nos corpos indígenas, a cristandade ingressaria no Milênio Joaquimita, em que a felicidade se alcançaria neste mundo
\end{abstract}

\footnotetext{
${ }^{84}$ Antonio Ruiz de Montoya (Lima, 1585-1652) foi um sacerdote jesuíta peruano e que escreveu a primeira gramática escrita da língua guarani: Tesoro de la lengua guaraní, publicado em 1639 em Madri, na Espanha (WIKIPEDIA)

${ }^{85}$ Claude d'Abbeville ( - Rouen,1632) foi um religioso e entomólogo francês. É autor de História da missão dos padres capuchinhos na ilha de Maranhão e terras circunvizinhas. (WIKIPEDIA)
} 
(...). Essas utopias se opunham tão cruamente ao projeto colonial que a guerra se instalou prontamente entre colonos e sacerdotes (...). (Ribeiro, 2008, p. 61, 62).

O entusiasmo de Oswald com a ação missionária pressupunha que o mundo compartilhado por jesuítas e índios reservava espaço para uma visão lúdica e solidária da vida. Parecia-lhe que a sociedade litúrgica e utópica almejada ali era um reflexo do latente anseio matriarcal de retorno à vida ociosa, préescravidão, que traria a reboque um "desrecalque" do "orfismo" humano. O sentimento "órfico", por sua vez, é visto, paradoxalmente, como a matéria prima da manipulação sacerdotal, mas também como a fonte de resistência ao mundo desencantado e racionalista do negócio.

Max Weber teorizou em detalhes o que genericamente Oswald chamava de “concepção áspera da vida”. Segundo Weber, o protestantismo é a estação final do longo processo histórico-religioso de desencantamento do mundo inaugurado pelo monoteísmo judaico e pelo cientificismo helênico; processo que favoreceu a rejeição dos meios mágicos de compreensão da vida, como sendo superstição ou sacrilégio. Sem dúvida, este "amadurecimento" do homem ocidental é uma das causas centrais da edificação de uma civilização com domínio técnico assombroso e com feitos grandiosos nas áreas da ciência, da arte e do direito.

Com o protestantismo, o desencantamento atingiria um novo grau. Em conformidade com os preceitos da doutrina da eleição, os mínimos elementos sensuais e emocionais ligados à experiência religiosa passaram a ser vistos como fúteis ou prejudiciais à salvação. Aliado a uma intensa racionalização do comportamento $^{86}$, nasceria ali uma ascese puritana que passou a recusar

\footnotetext{
${ }^{86}$ Como já foi dito, não pretendo me prender aos meandros da tese weberiana. Todavia, alguns esclarecimentos são necessários por conta dos possíveis mal-entendidos gerados pelo excesso de generalizações. Da mesma forma como afirmei anteriormente que o protestantismo não pode ser acusado de ter inventado nem o capitalismo nem a ganância, aqui, é preciso esclarecer que, quando Weber sugere que o protestantismo é a "última estação" de um processo de desencantamento não infere disso uma sequência linear e transparente de causas que levaram, por um aumento gradual, o desencantamento da antiguidade grega e judaica ao protestantismo. Na verdade, os processos históricos ocorrem de forma caótica, concomitante, se contaminando mutuamente e só podendo ser discriminados de forma retrospectiva. Assim, como explica André Berten: “A 'marca' calvinista só pode aparecer em um contexto propício a este tipo de racionalização, entre outras razões, porque a burguesia já estava de alguma forma predisposta a aceitar certas formas de racionalização de seu comportamento. E isso se deve, de um lado, pela relativa liberdade da burguesia em relação às restrições de sobrevivência, e, de outro, por seu espírito pragmático (e, provavelmente, em razão
} 
radicalmente as ilusões sentimentais, e a propor uma relação exclusivamente íntima e interior com Deus, a fim de evitar ao máximo qualquer profanação idólatra. Tudo isso teria tido como consequência:

\begin{abstract}
A absoluta negativa perante todos os elementos de ordem sensorial e sentimental na cultura e na religiosidade subjetiva - pelo fato de serem inúteis à salvação e fomentarem as ilusões do sentimento e a superstição divinizadora da criatura (...). Por outro lado, constitui uma das raízes daquele individualismo desiludido e de coloração pessimista como o que ainda hoje percute no "caráter nacional" e nas instituições dos povos com passado puritano; o contraste é marcante em relação à maneira como a filosofia das luzes, mais tarde, viu a humanidade (...) (Weber, 2005, p. 96)
\end{abstract}

A visão de mundo protestante e suas práticas ascéticas, então, se colocam no pico de uma longa cadeia do desprezo à cultura dos sentidos e às formas míticas de explicação da vida, no Ocidente. Nessas culturas, presenciou-se, por tabela, a ruína de determinadas liturgias coletivas que criavam sentido para existência dos indivíduos na comunidade. Em algumas seitas genuinamente puritanas, por exemplo, chegou-se a proibir qualquer vestígio de cerimônia fúnebre, a pretexto de que poderiam alimentar as "superstitions" $\$$. Toda esperança se canalizou para os insondáveis desígnios da predestinação divina e para a relação sem mediações com Deus, tendo como sintoma uma:

Admoestação tantas vezes repisada na literatura puritana inglesa contra toda confiança na ajuda e na amizade dos homens. Profunda desconfiança dos amigos (...). Profundo isolamento interior (...) esse é o estado de espírito do crente puritano que no fundo só se ocupa consigo mesmo e só pensa na própria salvação. (Weber, 2005, p. 97)

A digressão conceitual sobre o noção de desencantamento em Weber é necessária, pois é em contraste com esse painel que emerge a noção de ContraReforma no idealismo antropofágico. Pode-se dizer, talvez, que o conceito é, ironicamente, uma forma "encantada" de resposta, e que, por isso mesmo, está

igualmente do fato de que a vida nas cidades estava liberta das relações de dependência no que diz respeito às hierarquias tradicionais). (BERTEN, 2011, p. 103)

${ }^{87}$ De forma dialética, porém, como observa Oswald: "o fim desse aparato horrífico da morte cristã é um sinal matriarcal de descristianização da morte e dos horrores do juízo final" (CFM. 1972, p.127) 
menos preocupada em retratar a realidade do que em criticar uma determinada realidade:

Quando falo em Contra-Reforma, o que eu quero é criar uma oposição imediata e firme ao conceito árido e desumano trazido pela Reforma e que teve como área cultural particularmente a Inglaterra, a Alemanha e os Estados Unidos da América. Ao contrário, nós brasileiros, campeões da miscigenação tanto da raça como da cultura, somos a Contra-Reforma, mesmo sem Deus ou culto. Somos a Utopia realizada, bem ou mal, em face do utilitarismo mercenário e mecânico do Norte. Somos a Caravela que ancorou no paraíso ou na desgraça da selva, somos a Bandeira estacada na fazenda. O que precisamos é nos identificar e consolidar nossos perdidos contornos psíquicos, morais e históricos (MU, 1972, p.153)

Do prisma antropofágico, então, a "verdadeira" (leia-se, a melhor) ContraReforma aconteceu aqui, pois aqui prevaleceram as inclinações matriarcais, "aqui foi o Sul que venceu". Por conseguinte, a luta nacional contra a colonização holandesa será alçada a marco da resistência fraternal do matriarcado ao individualismo patriarcal. Oswald acredita que apesar da metrópole, que inutilmente tentara nos negociar com os holandeses, a vitória, de fato, foi realizada por "Um índio poty. Por um Negro - Henrique Dias. Por alguns lusonacionais - Matias de Albuquerque, Fernandes Vieira, Luis Barbalho. Por um Jesuíta - o orador sacro Antônio Viera" (MU, 1972, p. 182).

Antonio Vieira, em especial, muda completamente de figura. Há algumas décadas atrás era responsável por "uma deformação inquisitorial traduzida em português por sua violenta mediocridade" (DD, 1990, p. 41). Mas agora não. Nesse momento, Viera ganha ares de Herói e merece, portanto, algumas páginas entusiasmadas nas quais são citadas partes do Sermão pelo Bom Sucesso das Armas de Portugal contra as de Holanda. O que interessa Oswald nesse sermão é que, diante da possibilidade de Deus ter abandonado Portugal, Vieira parece desafiá-lo em nome de um princípio mais alto de Justiça, em frases como: "Quero eu Senhor, converter a vós" e "não hei de pedir pedindo, pois esta é a licença e a liberdade de quem não pede favor, senão justiça” (MU, 1972, p. 183).

Acima de tudo, esta lhe parecia uma guerra profética, pois prenunciava as demandas seculares por justiça tão marcantes nas revoluções modernas. De modo que se enganam os que enxergam ali um mero embate entre monopólio e livre- 
comércio, ou interesses dinásticos. $\mathrm{Na}$ verdade, era a "primeira luta titânica, no mundo moderno, entre o ócio e o negócio. E o ócio venceu.” (MU, 1972, p.189). Escrevia-se mais um capítulo da eterna oposição entre o matriarcado e o patriarcado:

Na Guerra Holandesa vencia, evidentemente, uma compreensão lúdica e amável da vida, em face dum conceito utilitário e comerciante. O Brasil compusera-se de raças matriarcais que não estavam distantes das concepções libertárias de Platão e dos sonhos de Morus e de Campanella. Era o ócio em face do negócio. O ócio vencia a áspera e longa conquista flamenga, baseada no primeiro lucro e na ascenção inicial da burguesia. O Deus bíblico, cioso, branco e exclusivista era batido, no seu culto, reformado pela severidade e pelo arbítrio, por uma massa órfica, híbrida e mulata a quem a roupeta jesuítica dera as procissões fetichistas, as litanias doces como o açúcar pernambucano e os milagres prometidos. (MU, 1972, p.184)

Esta tensão ideológica continuaria a se reproduzir até o pós-guerra no século XX. Existe algo de paradoxal no discurso reformado que ao mesmo tempo em que radicaliza a submissão ao dogma divino, introduz a razão contra velhas e estagnadas tradições. A Reforma foi um duro golpe para o messianismo católico, pois soube acompanhar de perto a guinada mental que, no século XVI, transferiu êxito e prestações de contas para a terra, horizontalizando as aspirações da humanidade ocidental, até então condicionada pela retórica celestial do sacerdócio católico. "O próprio Benjamin Franklin não deixa de participar desse culto à razão que, afinal, não passa de um culto a uma razão de classe, à razão burguesa (...). Na declaração da Independência dos Estados Unidos, anunciam-se "verdades evidentes por si”. (CFM, 1972, p.113)

Arquitetada inicialmente sobre o livre exame, essa "razão de classe" determinou o despojamento do burguês imigrante nos EUA da modesta ética que trazia da sua formação nas cidades europeias. Na América do Norte, pouco a pouco, ele se desfez da ascese puritana sem abandonar o ímpeto disciplinar que, aliado à crença na liberdade de lucro, forjou o "rei do prego, o príncipe do cachorro quente e o caldilho da parafina" (ASV, 1991b, p. 74). Na opinião de Oswald, tudo isso foi favorecido pelas amplas vantagens da comunicação direta com Deus. "Aos domingos. Pois já se disse - na segunda-feira é com os advogados e demais exatores do capital que se entendem os varões de Wall Street, 
para mandar cristãmente esfolar a pele do próximo durante o resto da semana" (Ibidem).

Oswald julgava que o próprio sucesso da Reforma levou o cristianismo a um impasse, pois abrira mão de suas raízes comunais e sociais. Citando o filósofo americano Josiah Royce, ele pondera que no cristianismo o que vale é o ensinamento ecumênico, isto é, a experiência social e não individual. Por outro lado, o pecado original nada mais é do que o eterno conflito entre indivíduo e sociedade.

Defronte a subversão que a Reforma supostamente impõe ao sentido primitivo do cristianismo, surge no horizonte do Ocidente um novo messianismo. É o comunismo, que ameaça a vida do, agora, pródigo e ostentoso burguês. Oswald satiriza a obra de Marx e Engels chamando-a de novo evangelho. A terra prometida dessa vez é a URSS. Por outro lado, Marx é uma nova versão de Maomé, tal a força profética de seu discurso que imediatamente estabelece os dogmas da revolução proletária. Seguidos à risca, sem dúvida acarretariam a dissolução do Estado. A eterna batalha entre senhores e escravos chegava ao fim, e com ela anunciava-se o tão esperado paraíso solidário na terra.

Porém, no meio do caminho, algo inesperado ocorre:

O novo Messianismo deixara a sua fase de recuperação psíquica, originado, como sempre, na depressão das massas e no caos social, e entrava na sua fase dogmática. Era o último avatar dos sistemas disciplinares que haviam domado o mundo cristão. Em vez da síntese esperada entre burguesia progressista e o comunismo, outra se processava dentro dos umbrais ideológicos da URSS - a síntese entre a Reforma e a Contra-Reforma. Santo Inácio e Lutero davam-se as mãos no "A-B-C" de Bukharin. "É a vontade divina que decide se o ato é bom ou mau" - escrevia o monge da Reforma. Agora era o Partido que decidia, impondo o Perinde ac cadáver a seus catecúmenos. Sob o signo da ação, os novos legislados perdiam contato com crítica e autocrítica e, sem perceber, mergulhavam nos domínios da Ontologia, da Apologética e da purificação pelo expurgo.

Lênin já declarara o seu horror a qualquer ceticismo. Nas suas mãos triunfais, o marxismo deixa de ser método para ser transcendência. Está criada, pelos sequazes a metafísica proletária (...).

Quem poderia prever, quem ousaria sonhar que o Messianismo em que se bipartiu a religião do Cristo (Reforma e Contra-Reforma) iria medrar no terreno sáfaro das reivindicações materialistas do marxismo? (...).

Mas a autocrítica desapareceu. Toda a crítica naufraga no sectarismo. O perfeito militante é o mesmo boneco farisaico do puritanismo - socrático ou americano que se apresentou ao mundo para edificá-lo, pedante, cretino, faccioso. E não 
seria mais estranho ouvirmos uma noite, pela boca universal da Radio-Moscou, que foi proclamado o Dogma da Imaculada Revolução. (CFM, 1972, p. 119-120)

Percebe-se como a antropofagia procura desalinhavar-se de ambos os lados da bifurcação ideológica dos anos 1950. Ocorre que, a despeito do passado modernista de "palhaço da burguesia" ou do passado recente de "comunista militante", Oswald sempre foi, acima de qualquer coisa, um utopista. Inclusive, como bem interpretou Benedito Nunes, a utopia (definida como "sinal de inconformação e prenúncio de revolta") é certamente uma das concepções que unificam a filosofia antropofágica. Pois é em torno dessa ideia que, sob as mais variadas roupagens, acompanhamos a história das civilizações se estendendo por ciclos utópicos de revoltas, nas quais se confrontaram as tendências primordiais do matriarcado e do patriarcado.

De 1945 em diante, Oswald dizia ter se "politizado na direção de seu socialismo consciente" (ASV, 1991, p.75). Para Nunes, isso significava que ele:

Jamais fez na realidade, a distinção, sabidamente estratégica, entre socialismo utópico e socialismo científico. Manteve ele no marxismo a dimensão ética das doutrinas do chamado socialismo utópico (Proudhon, sobretudo), e o antiestatismo anarquista de um Kropotkin. Seu socialismo jamais deixou de ser, fundamentalmente, o da rebeldia do indivíduo contra o Estado, mais interessado numa sociedade nova, cuja vida passava pela morte da organização estatal, do que no fortalecimento de uma ditadura do proletariado. Daí ter ele assimilado o marxismo ao ciclo das utopias, e isso reagindo ao caráter messiânico de que se revestirá na Rússia, como ideologia do Estado (Nunes, 1972, liii).

$\mathrm{Na}$ ocasião, portanto, muito mais do que o antagonismo entre comunismo (socialismo) e capitalismo (liberalismo), interessava a Oswald a forma dialética pela qual interagiam a técnica e os costumes. Por isso, parecia-lhe que os EUA acenavam com novas diretrizes matriarcais para a civilização ocidental. Apesar dos crimes de concentração de capital e de imperialismo, dos quais eram usualmente acusados, esboçava-se ali "o clima do mundo lúdico e o clima do mundo técnico aberto para o futuro" (CFM, 1972, p. 127).

Oswald ironizava o existencialismo em voga na sua época, explicando que aquela filosofia do desespero, nada mais era do que o reflexo do tédio da 
burguesia culta, que constatando a mediocridade de seu cotidiano decidia pela angústia como solução:

Um filósofo como Karl Jasper não compreende o que significa, para a massa democrática que sobe, o esporte, o recordismo, a glória de Tarzan e a glamour girl. Não compreende que o mundo do trabalho, graças à técnica e ao progresso humano, passa os encargos sociais para a máquina e procura realizar na terra o ócio prometido pelas religiões no céu (CFM, 1972, p.127)

Nesse momento, a técnica em estágio avançado passava da ênfase na produção para o mercado, socializando pelo consumo seus produtos: "indo levar à África mais remota ou às ilhas da Oceania o mesmo livro e o mesmo ferro de engomar, a mesma chuteira e a mesma televisão que marcavam de superioridade os países mecanizados" (MU, 1972, p.152).

Hoje vemos que as projeções de Oswald sobre os efeitos da alta-tecnologia nos costumes estavam apenas parcialmente corretas. Se, de fato, houve uma homogeneização cultural pelo consumo e uma transferência de cultos para idolatria midiática, por outro lado, como bem observou Vera Figueiredo, isso: "não diminuiu a necessidade de lucro, nem levou a reforma do capitalismo, e o tempo livre só aumentou sob a forma de desemprego" (Figueiredo, 2010, p.397).

Não podemos dizer, porém, que Oswald não previa os riscos sociais de uma globalização capitaneada pelos EUA. Ao lado do entusiasmo pelo que, na cultura americana, representava agressão ao messianismo ocidental, manifestava todo seu ceticismo quanto às raízes reformistas do país. Àquela altura, pensava ele, era preciso acrescentar ao desenvolvimento técnico o avanço ético das culturas miscigenadas:

Não se pode confundir uma fase da História com a própria História. Temos que aceitar a superioridade inconteste do calvinismo baseado na desigualdade como alentador da técnica e do progresso. Mas hoje, conquistados como estão os valores produzidos pela mecanização, chegou a hora de revisar e procurar novos horizontes.

Que é a história, senão um contínuo revisar de idéias e de rumos? (CFM, 1972, p. 152) 
Vencida a guerra contra o nazismo, os Estados Unidos como um dos líderes dos aliados carregava uma incômoda pedra no sapato: o negro norteamericano não tinha garantido seus direitos civis, viviam "apartados como animais" no "campo de concentração do Harlem" (ASV, 1991, p.72). Isso sem contar com a política do macarthismo dos anos 1950.

Silviano Santiago nota que, de 1945 em diante, Oswald deixa cada vez mais de lado o interesse romântico pela cultura indígena e se inclina para uma visão corrente dos estudos sociais nos anos 30/40, na qual se comparava os tipos de escravidão nas Américas, em particular a dos EUA e do Brasil. Influenciado por Gilberto Freyre e pela tese do "melting pot" da americana Margareth Mead, Oswald tinha em alta conta a hipótese, hoje tão controversa, da democracia racial. Uma vez que somos todos mulatos, nos trópicos não existiria preconceito racial, mas apenas social.

Não podemos omitir um comentário sobre os equívocos que certos idealismos compartilhados pela antropofagia podem acarretar. É mais do que discutido os falseamentos que a tese da democracia racial pode forjar. E não pretendemos, aqui, endossá-los, de forma alguma. Além disso, como argumentei nos capítulos anteriores, não há dúvida de que no terreno das evidências documentais ou dos recentes estudos antropológicos e historiográficos, muitos dos "fatos" narrados pela antropofagia não se sustentam. Por isso, insisto em frisar que o que me interessa neste trabalho é a sua crítica ideológica, sua reflexão abstrata, literária e imaginativa. É desse aspecto, creio eu, que as ideias oswaldianas, concordemos com elas ou não, podem alimentar os debates contemporâneos.

Assim, apesar da controvertida noção de democracia racial, a insistência de Oswald de que o exemplo da miscigenação brasileira deveria guiar as questões de primeira ordem no contexto do pós-guerra terminaram por se mostrar proféticas. Mais uma vez, é Silviano Santiago quem pode nos detalhar o porquê:

Os Estados Unidos, ao assumir o controle mundial da economia depois de 1945, e os países ricos da Europa, ao retomarem o fluxo de modernização interrompido pelas perdas e desgastes da Segunda Grande Guerra, foram levados a se valerem, para o trabalho sujo, de cidadãos de outras nações, muitas vezes de outras etnias e certamente de outros credos religiosos. Para dar alguns poucos e significativos 
exemplos: é o caso nos Estados Unidos do hispano (os grupos de mexicanos e porto-riquenhos são hoje aumentados por levas de sul-americanos), na Alemanha o do turco e do português, na França, mas também em vários outros países europeus, o do árabe e do negro. Provisões legais de migração e de cidadania foram instituídas para que esses novos "imigrantes" não o fossem, gerando uma situação econômica e social precisa em que esses operários se transformaram em cidadãos de segunda categoria, semelhantes aos negros norte americanos antes do "Civil Rights Act", promulgado em 1964 durante o governo Johnson. (Santiago In: Andrade, 1991b, p. 20)

Para antropofagia, a Contra-Reforma e a Guerra Holandesa são o primeiro anúncio de uma luta moderna que se estenderia até hoje. Contra-Reforma nada mais é do que um ícone antropofágico, que unifica os ideais de miscigenação e utopia. Em termos críticos, isso significa o questionamento da civilização ocidental no que ela traz de exclusivismo, em prol do que nela mesma é plural e descentrado.

Em favor de uma noção de humanidade sem hierarquias racistas e xenófobas, fazendo do valor da pluralidade a impossibilidade de uma liderança única, e ao mesmo tempo um agente positivo de solidariedade, é que Oswald sentencia ao fim da segunda guerra:

O que se devia fazer com a Alemanha depois da Guerra? Esfolar inteira? Comunizar? Entregar todinha aos noruegueses, aos gregos e aos russos? Aos filhos dos fuzilados, dos enforcados e dos bombardeados do mundo inteiro? Dá-la aos judeus? Não! É preciso alfabetizar esse monstrengo. Há dentro dela um raio esquivo de luz. É o do seu Humanismo. É o que vem de Goethe e através de Heine produz Thomas Mann. A Alemanha racista, purista e recordista precisa ser educada pelo nosso mulato, pelo chinês, pelo índio mais atrasado do Peru ou do México, pelo africano do Sudão. E precisa ser misturada de uma vez para sempre. Precisa ser desfeita no melting-pot do futuro. Precisa mulatizar-se. (ASV, 1991, p84).

À procura da síntese que expressasse uma visão de mundo tolerante, Oswald costumava relegar a realidade para um segundo plano. É difícil precisar nas concepções de Contra-reforma e de miscigenação até que ponto influem o sentimento de inferioridade e o júbilo da diferença. De qualquer forma, percebe-se claramente que a imparcialidade não é prioridade. Com isso, no delicado assunto das diferenças culturais, penso que Oswald acerta por um lado e erra por outro. 
Ele erra, como tantos outros intelectuais de países periféricos, ao deixar sem explicação porque países pobres têm o direito automático ao etnocentrismo que tanto criticam no discurso dos países ricos. Ora, ou nenhum dos dois têm direito ou os dois têm. É intelectualmente desonesto negar ao outro o pressuposto discursivo de que se faz uso. Enquanto desenvolve a concepção de Contrareforma, Oswald muitas vezes assume o tom exclusivista que pretende criticar e termina deixando de lado os raciocínios deslizantes que produzem a mistura de ceticismo e idealismo tão marcante nos ensaios.

Todavia, a parcialidade com que explora o assunto, demonstra que o dilema não é de fácil resolução. Mal ou bem, Oswald nos ajuda a ver o quanto é difícil atenuar a hierarquização entre as sociedades, no sentido de realmente entendê-las segundo suas próprias lógicas históricas e culturais. Muito já se falou sobre a falsa neutralidade da crítica iluminista-progressista europeia às suas excolônias. Porém, o fato é que não está claro qual seria o terreno discursivo propício para uma possível mediação universal entre culturas diferentes.

Até agora, se impôs o discurso da universalidade negativa da modernidade capitalista liberal. Ao menos foi nele que conviveram em relativa paz as mais variadas mentalidades laicas e religiosas de diferentes culturas ${ }^{88}$. A grande questão é saber se o mérito foi do capitalismo de trocar de todos os valores pelo valor de troca ou se a modernidade foi muito mais do que isso. Acredito que Oswald procurava respostas nessa segunda opção.

\footnotetext{
${ }^{88}$ Pensemos na imagem caricata, mas teoricamente possível, de uma fila de supermercado com um mulçumano, um judeu ortodoxo, um mórmon, uma celebridade gay, um empresário milionário, um sindicalista marxista, etc., todos tendo o mesmo direito legal de estarem lá para comprar seus produtos e viverem suas vidas privadas como bem entenderem. Que outro tipo de sociedade possibilitou essa convivência, senão as modernas democracias capitalistas?
} 


\section{6 \\ Conclusão}

Todos os possíveis somados não dão a liberdade, mas o impossível é escravidão. O próprio caos, também é uma servidão (...). Quando já não se consegue dizer o que é preto e o que é branco, a luz se apaga e a liberdade torna-se uma prisão voluntária.

Albert Camus

No meio do século passado, Sartre publicou uma famosa conferência na qual se defendia das acusações de ser um anti-humanista. Na ocasião, buscou diferenciar duas acepções de humanismo. A primeira, oriunda do iluminismo, embora abdicasse da noção de Deus, não abria mão da ideia de que a essência humana precedia sua existência e, dessa forma, tomava o homem como um fim. Sartre zombava dos defensores dessa ideia que se sentiam honrados como homens, devido aos atos particulares de alguns homens: "Este humanismo é absurdo porque só um cão ou um cavalo poderia emitir um juízo de conjunto sobre o homem e declarar que o homem é espantoso" (Sartre, 1970, p.266-67). Para ele, o único humanismo possível era aquele que afirmava não haver outro universo que não o da subjetividade humana. $\mathrm{O}$ homem, portanto, longe de ser um fim, é sempre um início, isto é, sua existência precede a ideia que constrói sobre sua essência. Nesse sentido, ele se considerava um existencialista-humanista.

Sartre não foi o primeiro a rejeitar o conceito iluminista de humanidade. $\mathrm{O}$ humanismo do esclarecimento, apesar de todo o prestígio que gozou do século XVIII em diante, sempre contou com ilustres adversários, teístas ou ateístas. Porém, esse discurso pronunciado em 1946, logo após o fim da Segunda Guerra Mundial, parece revelar aos olhos contemporâneos o prenúncio (ou diagnóstico) do declínio de uma visão de mundo que por alguns séculos teve enorme ascendência sobre o Ocidente. 
Atualmente, embora não haja consenso sobre a melhor alternativa ao ideário iluminista, é notória a falência de sua autoridade diante dos sucessivos ataques a seus preceitos filosóficos e políticos. Nas ciências humanas, em particular, sobram condenações enfáticas ao menor vestígio de racionalismo, além de sarcasmo para com as velhas teses igualitaristas. A convicção na aliança entre razão e justiça social, preponderante até pouco tempo, passou a ser vista como um meio sorrateiro de asfixiar as diferenças.

Por conta disso, alguns intelectuais investem contra as noções de sujeito cartesiano, de tempo linear e contra as teorias políticas derivadas dessa matriz conceitual. Outros enfatizam que a hegemonia inconteste do capitalismo de mercado exige um entendimento complexo das relações entre linguagem, conhecimento e poder, assim como um olhar renovado para as leis que regem o campo estético. Embora, na maior parte das vezes, os argumentos não sejam propriamente contemporâneos, é visível a estabilização de um novo vocabulário para a abordagem de velhos temas filosóficos.

Por meio de diferentes dicções, esse vocabulário afirma que deveríamos pensar em identidades fluidas, em tempos fragmentados, nos movimentos micropolíticos e nas intensidades afetivas para evitar as avaliações estreitamente ideológicas da vida moral e da realidade social. No campo artístico, propõe-se que abandonemos as interpretações logocêntricas, excessivamente presas a conteúdos estáveis e a propósitos autorais, em favor da apreensão/expressão de uma arte nas fronteiras do irrepresentável, situada em terrenos proto-intencionais e protosemânticos, que possibilite a experimentação de novos modos de afecçãocognição.

Sem dúvida, não há como desprezar as evidentes transformações políticas e culturais da época de Sartre para cá. Nossa realidade, marcada pela instantaneidade e pela virtualidade, demanda teorias que dêem conta de novas formas de subjetividades em contato com um novo meio social. Apesar disso, frente às desilusões e deslumbramentos que tais mudanças têm ocasionado, penso que a releitura cuidadosa de alguns debates do passado recente pode ajudar a levantar questões por vezes ignoradas. 
Não é difícil, por exemplo, encontrar nessas discussões críticas arrasadoras às concepções idealistas da consciência. Ao longo da tese, comentamos os exemplos de Marx, Nietzsche e Freud. Mas, além deles, o que dizer das agressivas investidas de Wittgenstein, Bergson, Heidegger e dos pragmatistas americanos contra o cartesianismo. Por outro lado, no que se refere à urgência contemporânea por uma arte não identitária, que agregue múltiplas temporalidades e rompa com a moldura platónica da forma/conteúdo, não foi outro o trabalho de Rimbaud, Mallarmé, Joyce, Beckett, Kafka, enfim, de todas as vanguardas europeias e latino-americanas.

Por conseguinte, talvez a modernidade não tenha sido assim tão "moderna" ou o que equivale talvez a contemporaneidade não seja tão "contemporânea" quanto se presume. A modernidade foi excessivamente conflitiva. Sua linguagem se debateu entre a idealização e a desmistificação. Ao mesmo tempo apaixonada pela crítica e nostálgica da unidade perdida. Crente no progresso e crítica da civilização.

A assertividade dos escritores modernos costumava reproduzir essa ambivalência nos frequentes fogos cruzados que ocorriam no meio político e cultural. Um exemplo disso é o ensaio A posição de Sartre, no qual Oswald de Andrade tece comentários sobre o intelectual francês, cinco anos após este escrever o texto citado no inicio:

\begin{abstract}
Jean-Paul Sartre não perdeu de modo nenhum a sua importância nem a sua alta popularidade. Continua a ser uma das figuras máximas do Ocidente intelectual. Mas houve, evidentemente, uma guinada na sua linha de conduta. Terá sido apenas, quem sabe, a acentuação e mesmo a definição de todo o seu passado inquieto, ou melhor, o delta de suas íntimas correntezas revolucionárias.

Essa acentuação e essa definição não exprimem um acréscimo do poder subversivo do mestre escritor. Dir-se-ia que Sartre termidorizou.

Disso pode-se encontrar uma verificação fácil na polêmica que ele manteve com outra grande figura das letras francesa, Albert Camus, que foi nosso hóspede dois anos atrás. Em termos de política social, um tomou a direita e outro a esquerda. E apesar do seu novo fervor pela União Soviética e talvez, por isso mesmo, quem ficou na ala conservadora foi Sartre. Camus tomou para si a defesa do irredutível que é o indivíduo e da sua intocável liberdade. (PS, 1972, p.216).
\end{abstract}

O utopista social Oswald de Andrade acusa o existencialista Sartre de abandonar a intocável liberdade do indivíduo em nome do comunismo. Oswald 
não era exatamente um arauto do individualismo ou um embaixador do liberalismo econômico. Por outro lado, o autoritarismo soviético lhe parecia a pior das soluções. Seria ele um "social democrata"? Não creio. Tal categorização parece dizer mais a respeito do nosso olhar contemporâneo do que propriamente da posição política do autor. De que ponto de vista, então, Oswald se coloca na defesa simultânea da igualdade de direito e do direito à diferença?

Propus no segundo capítulo que a singular mistura entre demanda individual e coletiva, nos ensaios, reflete influências simultâneas de Nietzsche e Marx nas ideias de Oswald. Todavia, essa duplo registro também é um sintoma do enraizamento concomitante da antropofagia oswaldiana nas vertentes idealista e iconoclasta da modernidade. De um lado sua filosofia apresenta sinais da aposta iluminista na razão como mediadora social, capaz de produzir liberdade e justiça, independente da lei de Deus. De outro, porém, a antropofagia é um legítimo fruto das vanguardas e da sua crítica à civilização e à racionalidade.

O choque entre os dois vetores não se resolve nos ensaios, o que produz interpretações díspares do pensamento de Oswald. Da forma como o leio, seu maior interesse era criticar as manipulações messiânicas do que considerava o aspecto transcendente do homem, assim como a exploração social resultante dessa manipulação. Por isso penso que, de certa forma, a antropofagia compartilhava do ideal de autonomia idealizado pelo iluminismo.

Oswald era decididamente um adversário do pensamento conservador que denegria a valorização moderna do homem frente a Deus ${ }^{89}$. Ele não partilhava, por exemplo, o lamento de que o ser-humano estava sendo abandonado diante do enigma da morte e do mal sem a religião. Não concordava, igualmente, com a típica alegação conservadora de que o "esclarecimento", inadvertidamente, deu rédea solta ao inato egoísmo do ser-humano, e que os ganhos técnicos e sociais trazidos com a ascendência do racionalismo não superavam sua capacidade de destruição.

\footnotetext{
${ }^{89}$ Em 1950, dizia Oswald: "Pode-se dividir nitidamente a polêmica contemporânea, mesmo sem ela indicar uma contradita direta de pontos de vista. Há de um lado o marxismo, com suas formas clássicas ou espúrias, do outro a reação que contém desde a alta especulação existencialista alemã até o teimoso e inútil catolicismo francês, cujas formas de utilidade social se resumem na ação prática de um grupo culto de dominicanos e jesuítas - um Lebret, um De Lubac. Ora é forçoso encontrar-se uma terceira solução.” (OA, 1991, p.236)
} 
Um clássico retrato desse argumento é dado, curiosamente, pelo personagem racionalista Ivan Karamazov. Ele vaticina o destino imoral reservado ao homem moderno por ter tirado Deus do seu trono.

\begin{abstract}
ele (Ivan Fiodorovitch Karamazov) declarou em tom solene que em toda a face da terra não existe absolutamente nada que obrigue os homens a amarem seus semelhantes, que essa lei da natureza, que reza que o homem ame a humanidade, não existe em absoluto e que, se até hoje existiu o amor na Terra, este não se deveu a lei natural mas tão-só ao fato de que os homens acreditavam na própria imortalidade. Ivan Fiodorovitch acrescentou, entre parênteses, que é nisso que consiste toda a lei natural, de sorte que, destruindo-se nos homens a fé em sua imortalidade, neles se exaure de imediato não só o amor como também toda e qualquer força para que continue a vida no mundo. E mais: então não haverá mais nada amoral, tudo será permitido, até a antropofagia. Mas isso ainda é pouco, ele concluiu afirmando que, para cada indivíduo particular, por exemplo, como nós aqui, que não acredita em Deus nem na própria imortalidade, a lei moral da natureza deve ser imediatamente convertida no oposto total da lei religiosa anterior, e que o egoísmo, chegando até ao crime, não só deve ser permitido ao homem, mas até mesmo reconhecido como a saída indispensável, a mais racional e quase a mais nobre para a situação. (Dostoiévski, 2009, p.109).
\end{abstract}

O raciocínio de Oswald parte de uma lógica diametralmente inversa a de Ivan Karamazov. No terceiro capítulo, expus o argumento do autor, segundo o qual era a consciência da mortalidade, expressa pela metáfora da antropofagia, que fundava a solidariedade primitiva. A visão de mundo matriarcal não apagava a angústia metafísica diante da morte e do mal, por isso Oswald resumia as teogonias primitivas na fórmula "Deus é o mal". A ausência do socorro supraterreno representava a alternativa horizontal do matriarcado frente à lógica messiânica da recompensa e do castigo.

Penso que esta questão fundamental, não raro, foge à crítica contemporânea da filosofia do sujeito iluminista. Trata-se de uma pergunta que rondou as cabeças modernas e que, até hoje, parece não ter tido uma resposta satisfatória: a liberdade está na mão dos seres humanos ou estes são os primeiros a liquidá-la?

O intrigante nas teorias pós-modernas é que muitas vezes elas criticam as filosofias da consciência como uma mera continuidade da "prisão" metafísica, exigindo, portanto, mais autonomia. Sem perceber, porém, demandam a 
realização do ideal estabelecido pelo próprio sistema de pensamento que querem desmontar.

Para escritores como Dostoievski, no entanto, o problema era bem outro. Ele pensava que no momento em que se desse ao ser humano alternativas (autonomia), ele iria fatalmente se dirigir para a opção mais fácil da desonra.

Oswald não via as coisas dessa forma. Ele considerava esse tipo de raciocínio a interpretação patriarcal para "a morte de Deus" "90. Seu pensamento, ao contrário, partia do profundo pessimismo (a devoração) em direção ao profundo otimismo (a utopia). Por isso, a autonomia estoica do primitivo não era antitética à organização coletivista no matriarcado, mas complementar. Como comentei no quarto capítulo, para ele, a utopia, desde a parusia cristã até o Manifesto comunista, combateu fundamentalmente a associação entre exploração social e discurso religioso (ou, o Estado patriarcal).

Não pretendo, com isso, afirmar que Oswald era um inveterado iluminista que se ajoelhava diante do altar de Descartes ou de Kant. Apenas não o vejo compartilhando a aversão contemporânea à razão, à representação e aos conceitos totalizantes. Aliás, é bastante frequente vê-lo recorrendo a concepções universais. Principalmente ao tratar do que considera a dimensão transcendente do homem.

A distinção fundamental que separa no campo das ideias o século atual do século XIX, é a que estabelece que o século passado foi o do ateísmo sem Deus e por isso seus esforços anti-religiosos fracassaram, enquanto hoje vivemos a cultura de um século que admite o ateísmo com Deus. Parece sutil, mas não é. É que o

\footnotetext{
90 No caso específico dos russos, ele diz: "Há duas constantes que têm originado para a comunidade russa o mesmo debate milenar. Uma é a ortodoxia catequista, outra esse freudismo perene que gira entre o crime, o lamento e o remorso - o qual se poderia qualificar de sentimento dostoievskiano da vida e que no fundo não passa de um complexo de caverna. O povo russo como aliás outros povos, entre os quais o nosso, foi muito tempo mantido debaixo da mais vil servidão por uma pequena elite possuidora. Por milênios foi conservado no seu estado primitivista e natural, recorrendo o poder político para escravizá-lo à manutenção pela força da mais feroz ortodoxia religiosa e da mais titânica opressão cívica. De um lado os costumes matriarcais das tribos citas e tártaras, do outro o rigoroso ritual do formalismo cristão e do imperativo monárquico e policialesco. Lancinantemente se debateu entre essas constantes a comunidade eslava, dando conhecimento ao mundo de seus infernos conflituais através daquele que foi o maior romancista do século passado - Fiódor Dostoiévski. (...)

Esse sinal de ortodoxia cristã que passou intacto para a ortodoxia soviética terá sido a única tara histórica herdada pela comunidade russa em transformação? Ou permanecerá dentro dos quadros aparentemente racionalistas e científicos do sistema soviético aquela mania de torturar e ser torturado, a vontade de impor como de aceitar os sofrimentos, que faz da literatura russa o mais lancinante documentário do sadomasoquismo que já existiu. (VNL, 1991, p.220-221)
} 
século XIX, com sua compreensível auto-suficiência, foi além das barreiras em que a critica negativista deveria ter se contido na análise do fenômeno religioso. Este existe e existirá sempre. Ele afunda na nossa eterna irracionalidade (...) (CFM, 1972, p.172).

O fracasso do ateísmo sem Deus, a que se refere Oswald, é a expressão pontual de que o chamado sujeito racional, linear e transparente a si próprio (ou o "sujeito unificado") jamais se realizou por completo. Mesmo no auge do iluminismo e do cientificismo modernos, o racionalismo esteve sempre sob a vigilância do pensamento empirista, religioso, tradicionalista e, mais tarde, do romantismo e do modernismo, para citar alguns exemplos. Essas tensões dão a medida de que a modernidade nunca aceitou a razão como o único argumento para formar suas conviç̧ões sobre o que era o homem, o mundo ou o melhor para a sociedade e para os indivíduos em particular. Ao contrário, a própria razão se colocou sob suspeita por diversas vezes em nome de expressões culturais, crenças religiosas e liberdades individuais inexplicáveis racionalmente, mas que pareciam ser desejáveis ou aceitáveis.

Note-se, contudo, que a razão, ao negar seu estatuto de juíza absoluta, paradoxalmente, se afirma como mediadora do debate, uma vez que dogmas não têm, por definição, a possibilidade de serem refutados. Esse foi um dado que encorajou os racionalistas a se dedicarem as definições transcendentais da razão que tanto indignam as teorias pós-modernas.

A despeito da fracassada busca por leis transcendentes, não se pode contestar que o caminho inegável do racionalismo foi a relativização do poder absoluto das religiões e a consequente afirmação da ciência. De certa forma, portanto, a razão moderna também foi uma razão naturalista/empirista. Ao acreditar em si mesma, a razão inevitavelmente apostou na dúvida, fomentando a suspensão de juízo até a obsessão crítica. O racionalismo optou pela negatividade e pela relatividade, duvidando não apenas do destino e de Deus, mas também dos valores supremos, do bem, da verdade e da percepção física natural. Nietzsche diagnosticava essa desconfiança sistemática como uma segunda etapa do 
niilismo $^{91}$ : o niilismo passivo da modernidade. Para ele, o niilista passivo renegava a metafísica sem, no entanto, substituí-la pelos altos valores da vida e da realidade. Penso que, em parte, Oswald concordava com esse ponto de vista, e criticava o racionalismo niilista por abandonar as dimensões lúdicas do homem e da sociedade.

Assim, de cada um dos elementos disponíveis no repertório intelectual de sua época, Oswald fazia usos originais. Para ele o problema com o pensamento metafísico era transformar-se em razão de classe, e, portanto, em justificação da dominação elitista. Contra tal tipo de exploração não vejo Oswald abrindo mão dos recursos críticos da razão. Entretanto, é fato que ele contestava os racionalistas que almejavam suprimir do ser humano o usufruto das suas potencialidades irracionais.

Vimos no terceiro capítulo como Oswald elabora críticas a duas teorias de grande prestígio na década de 1940/1950: o marxismo e o existencialismo. Isso não significa, no entanto, que ele renegasse de cima a baixo as duas vertentes. Longe disso, ele dialoga com elas, lamentando apenas o ponto em que se perderam e cederam as heranças patriarcais das culturas de onde surgiram.

Quem sabe, então, pudéssemos pensar na razão não apenas como a velha entidade metafísica platônica que garante acesso ao mundo Real, e sim como um instrumento das conversações caracterizadas pelo debate, mais do que pela imposição e pelo dogma. Desse prisma, embora esteja claro o caráter fíctício do tal "sujeito cartesiano" - supostamente delineado em sua identidade, emitindo frases com significados estáveis e racionais, sobre contextos lineares - temos que reconhecer que, em parte, essa "ficção" logocêntrica fornece uma eficácia comunicativa da qual nem sempre podemos abrir mão. Para dar apenas um exemplo: como poderíamos ler traduções se não aceitássemos uma certa estabilidade dos significados emitidos intencionalmente pelo autor do original? ${ }^{92}$

Nesse sentido, quando Oswald escreve sobre a realidade social e subjetiva por meio de representações universalistas (matriarcado, patriarcado, o "homem natural", o "direito natural", o messianismo, o orfismo, a utopia etc.), trata-se da

\footnotetext{
${ }^{91}$ A primeira, como se sabe, era o platonismo e sua negação do mundo sensível em nome do mundo supra-sensível.

92 Sobre o assunto ver. (BRITTO, 1996) “Desconstruir para quê?”.
} 
manipulação de abstrações que não devem ser - e obviamente não são nunca substancializadas. É certo que não existem entidades materiais perfeitamente delimitadas tais como a "sociedade" ou a "história". Da mesma forma, ninguém espera encontrar o "inconsciente" freudiano vendo tv no sofá de casa, ou a “ideologia” de Marx bebendo cerveja num show de rock. Contudo, é possível que ambos estejam presentes nas duas situações.

Eventualmente, então, o que o pensamento contemporâneo repudia como "representações totalizantes" poderia ser entendido como conceitos que unificam várias operações feitas com signos em um conjunto coerente, e que parecem agir de modo regular sobre nossas vidas. Como explica Frederic Jameson (Jameson, 1994), por um lado, essas abstrações possibilitam um certo distanciamento da vivência imediata dos fenômenos, por outro, servem como uma espécie de caracterização geral de mecanismos aparentemente autônomos, mas que guardam afinidades entre seus domínios.

Antes de concluir, devo frisar mais uma vez que as generalizações de que fiz uso não têm o intuito de negar em bloco o pensamento contemporâneo, mas apenas de levantar pontos em que possamos localizar a antropofagia ensaística no amplo debate sobre a passagem do paradigma moderno ao contemporâneo. É evidente a importância de se pensar sobre os limites da razão, por isso as teorias contemporâneas herdeiras de Nietzsche, da filosofia da linguagem, da antropologia, dos estudos literários etc. merecem todo o prestígio por estarem convidando nossa imaginação a atuar para além da tradição representacionista do sujeito cognoscente / objeto do conhecimento. Não se pode ignorar, igualmente, que as várias denúncias aos "totalitarismos" do discurso humanista têm mostrado o quanto suas causas nobres encobriram e encobrem as mais vis modalidades de exercício de poder nos níveis institucional e moral.

$\mathrm{O}$ que ressalto é apenas o modo trivial pelo qual o iluminismo e a modernidade têm sido reduzidos a apenas mais um ato de fé (nos poderes metafísicos da razão), com a desvantagem de crer ingenuamente no progresso. Esse tipo de argumento geralmente ignora perguntas como: a expansão das liberdades privadas e dos direitos civis decorrentes da modernidade é ilusório? O crescimento das democracias (não obstante todos os vícios desse sistema) no lugar 
das monarquias absolutistas, teocracias, despotismos militares etc., é uma mudança para pior? A abolição da escravidão é irrelevante? Apesar de toda a destruição oriunda do conhecimento científico, pensada em larga escala, nossa qualidade de vida, de fato, piorou? Estas eram, sem dúvida, questões centrais para o pensamento de Oswald de Andrade.

Segundo Bruno Latour:

A dúvida sobre o bom fundamento das boas intenções fez com que alguns de nós tenham se tornado reacionários de duas formas diferentes: é preciso não mais querer acabar com a dominação do homem pelo homem, dizem alguns; é preciso não mais tentar dominar a natureza, dizem outros. Sejamos definitivamente antimodernos, dizem todos (Latour, 1994, p. 14).

Não vejo o Oswald dos ensaios como um autor anti-moderno nos termos descritos por Latour. É verdade que ao pensar sobre o seu tempo, ele podia assumir um tom hiperbolicamente crítico ou uma inflexão exageradamente otimista, mas isso, na minha opinião, só fazia da antropofagia uma teoria duplamente moderna.

Penso que os ensaios antropofágicos nos ajudam a entender que negar completamente a presença da ideologia, do sujeito, da razão e da metafísica nos nossos sistemas de sentido e jogos de linguagem equivale a não reconhecer o que há de ficcional, incorreto, repressivo e autoritário nessas ideias. Afirmar a realidade ou a ficção de tudo, a condicionalidade ou a incondicionalidade de tudo, o acaso ou o destino por trás de tudo são modos idênticos de aceitar com amabilidade teorias dogmáticas.

Já se disse que a operação antropofágica transforma o "ou" em "e". A observação, por simples que pareça, é provavelmente o mais difícil legado deixado pela antropofagia. Uma visão de mundo que, segundo o próprio Oswald de Andrade, ainda estava apenas engatinhando. 


\section{7 \\ Referências Bibliográficas}

ADORNO, T. W.; HORKHEIMER, M. Dialética do esclarecimento: fragmentos filosóficos. Rio de Janeiro: Jorge Zahar, 1985.

Notas de literatura I. São Paulo: Editora 34, 2003.

AGUILLAR, G. Por una ciencia del vestigio errático: ensayos sobre la antropofagia de Oswald de Andrade. Buenos Aires/Rio de Janeiro: Grumo, 2010.

ALENCAR, J. O suplício. In: RUFFINELLI, J.; ROCHA, J. C. de C. (Orgs.). Antropofagia Hoje. São Paulo: É Realizações, 2011.

ANDRADE, M. Aspectos da literatura brasileira. São Paulo: Livraria Martins editora, 1972.

ANDRADE, O. A Crise da filosofia messiânica. Tese para concurso da cadeira de filosofia da Faculdade de Filosofia, Ciências e Letras da USP. São Paulo, 1950.

- Do Pau-Brasil à antropofagia e às utopias: manifestos, teses de

concursos e ensaios. Rio de Janeiro: Civilização brasileira, 1972.

Estética e política. Rio de Janeiro: Editora Globo, 1991.

. Os dentes do dragão. Rio de Janeiro: Editora Globo, 1990.

Ponta de lança. Rio de Janeiro: Civilização Brasileira, 1972.

Feira das Sextas. Rio de Janeiro: Editora Globo, 2000.

Telefonema. Rio de Janeiro: Editora Globo, 1996.

Um homem sem profissão: memórias e confissões. Rio de Janeiro:

Civilização Brasileira, 1976.

A alegria é a prova dos nove: antologia. Luiz Ruffato (Org.). Rio de Janeiro: Editora Globo, 2010.

ANDRADE, R. Depoimento. In: MORAES, H. V.(Org.). Oswald Plural. Rio de Janeiro: Ed UERJ, 1995.

ANSELL-PEARSON, K. Nietzsche como pensador politico: uma introdução. Rio de Janeiro: Jorge Zahar, 1997.

AUERBACH, E. Ensaios de Literatura Ocidental. São Paulo: Editora 34, 2007. 
BACHOFEN, J. J. El matriarcado: una investigación sobre la ginecocracia en el mundo antíguo según su naturaleza religiosa y jurídica. Madrid: Ediciones Akal, 2008.

BACHUR, J. P. Individualismo, liberalismo e filosofia da história. In: Lua Nova,

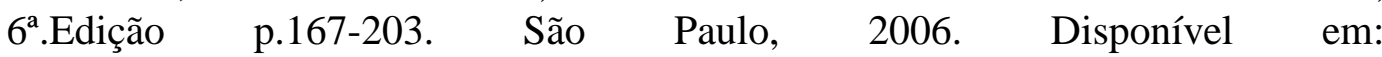
http://www.scielo.br/pdf/ln/n66/29088.pdf. Acesso em: 2 abr. 2010.

BERMANN, M. Tudo o que é sólido desmancha no ar. São Paulo: Companhia das Letras, 2007.

BERNABÉ, M. Topologias: las fronteiras críticas de la literatura latinoamericana. In: Grumo Latinoamerica. v. 6. p. 82-88. Buenos Aires/Rio de Janeiro, 2007.

Vidas de artista - Bohemia y dandismo en Mariátegui, Valdelomar y Eguren (Lima, 1911-1922). Rosario: Beatriz Viterbo Editora, 2006.

BERTEN, A. Modernidade e desencantamento - Nietzsche, Weber e Foucault. São Paulo: Editora Saraiva, 2011.

BLACKBURN, S. Dicionário de filosofia Oxford. Rio de Janeiro: Jorge Zahar, 1997.

BLOCH, E. O princípio de esperança. v.1. Rio de Janeiro: Contraponto/Ed. UERJ, 2006.

BOAVENTURA, M. E. O Salão e a selva, uma biografia ilustrada de Oswald de Andrade. São Paulo: Editora da Unicamp, 1995.

Oswald de Andrade, a luta da posso contra a propriedade. In: SCHWARZ, R. (Org.). Os pobres na literatura. São Paulo: Brasiliense, 1983.

BONFIM, M. América Latina, males de origem. Rio de Janeiro. Centro Eldestein de pesquisa social, 2008.

BOPP, R. Vida e morte da antropofagia. Rio de Janeiro: Civilização, 1977.

BORGES, J. L. Pierre Menard, autor del Quijote. 2012. Disponível em: http://www.literatura.us/borges/pierre.html. Acesso em: 22 ago. 2012.

BOSI, A. Ideologia e contra ideologia. São Paulo: Companhia das Letras, 2010.

1978.

História concisa da literatura brasileira. São Paulo: Editora Cultrix,

BOURDIEU, P. As regras da arte. São Paulo: Companhia das Letras, 2010.

BRITO, M. da S. As metamorfoses de Oswald de Andrade. São Paulo: Conselho Estadual de Cultura, 1972. 
BRITTO, P. H. Desconstruir para quê? In: Cadernos de tradução. Santa Catarina. (UFSC) v.2, n.8, 2001. Disponível em: http://www.journal.ufsc.br/index.php/traducao/article/viewArticle/5883. Acesso em: 23 set. 2011.

BUBER, M. O socialismo utópico. São Paulo: Perspectiva, 2007.

BURCKHARDT, J. A cultura do Renascimento na Itália: um ensaio. São Paulo: Companhia das Letras, 2009.

CAMPANELLA, T. A cidade do sol. Lisboa: Guimarães \& Cia Editores, 1980.

CAMPOS, H. Da razão antropofágica : a Europa sob o signo da devoração In: Revista Colóquio/Letras. Ensaio 62, Jul. 1981. p.10-25. Disponível em: http://coloquio.gulbenkian.pt/bib/sirius.exe/do?bibrecord\&id=PT.FCG.RCL.2600. Acesso em: 10 set. 2012.

CAMUS, A. O mito de Sísifo. Rio de Janeiro. Record, 2005.

O homem revoltado. Rio de Janeiro. Record, 2010.

CANDIDO, A. América latina em sua literatura. São Paulo: Perspectiva, 1979.

O Romantismo. Humanitas FFLCH/USP, 2002. Disponível e m: http://pt.scribd.com/doc/458354/O-Romantismo-no-BrasilAntonio-Candido. Acesso em: 10 set. 2012.

Brigada ligeira. Rio de Janeiro: Ouro sobre Azul, 2006.

Literatura e sociedade. São Paulo: Cia Editora Nacional, 1967.

Vários escritos. Rio de Janeiro: Ouro sobre Azul, 2004.

CARDOSO, M. R. Intempestividade e perspectivismo: exercícios de releitura de Oswald e Murilo Mendes. In. Contexto. Espirito Santo (UFES) N.20, 2011/12. Disponível em: http://www.ufes.br/ppgl/matriz/pdf/Contexto_20_-_20112_PPGL_Ufes.pdf. Acesso em: 12 nov. 2012.

Glauber "fabulista fabuloso". In: Scielo . v.12, N.1, São Paulo, 2010. Disponível em: http://www.scielo.br/pdf/alea/v12n1/v12n1a05.pdf. Acesso em: 12 nov. 2012.

CARPENTIER, A. A literatura do maravilhoso. São Paulo: Vertice, 1987.

CASSIRER, E. Antropologia filosófica: introdução a uma filosofia da cultura Humana. São Paulo: Mestre Jou, 1977.

A filosofia do iluminismo. Campinas: Unicamp, 1997.

El mito del estado. México: Fondo de cultura, 1968. 
CERTEAU, M. de. A escrita da historia. Rio de Janeiro : Forense-Universitaria, 1982.

A invenção do cotidiano. Petrópolis: Vozes, 1998.

CHAUÍ, M. Vida e obra de Montaigne. In: Os pensadores. São Paulo: Nova cultural, 2000.

CICERO, A. Finalidades sem Fim. São Paulo. Cia das Letras, 2010.

CLASTRES, P. Arqueologia da violência: ensaios de antropologia política. São Paulo: Brasiliense, 1982.

A sociedade contra o estado. São Paulo: Brasiliense, 1982b.

COLEBROOK, C. Gilles Deleuze. London/New York: Routledge, 2006.

COSTA LIMA, L. Limites da Voz - Montaigne, Schlegel. Rio de Janeiro: Rocco, 1993.

CUNHA, E. Os Sertões. Rio de Janeiro: Biblioteca Nacional - Domínio Público. Disponível em: http://www.dominiopublico.gov.br. Acesso em: 17 set. 2012.

DANTAS, V. O canibal e o capital - a arte do Telefonema de Oswald de Andrade. In: Terceira margem online. UFRJ Rio de Janeiro, 2004. Disponível em: http://www.ciencialit.letras.ufrj.br/terceiramargemonline/numero12/xix.html. Acesso em: 1 abr. 2009.

DELEUZE, G. Conversações 1972-1990. Rio de Janeiro: Ed 34, 1992. Nietzsche e a filosofia. Rio de Janeiro: Editora Rio, 1976.

A ilha deserta e outros textos: textos e entrevistas (1953-1974). São Paulo: Editora iluminuras, 2006.

DELEUZE, G.; GUATARRI, F. Mil platôs: capitalismo e esquizofrenia. Rio de Janeiro: Editora 34, 1995.

DIAS, R. Dionísio na Grécia apolínea. In: LINS, D.; PELBÁRT, P. (Orgs). Nietzsche e Deleuze, bárbaros, civilizados. São Paulo: Annablume, 2004.

DINIZ, J. Antropofagia e Tropicália - devoração/devoção. In: Cuadernos de Intercambio Rosário / Rio de Janeiro. v.1, n.1. Rosario: Universidad Nacional de Rosario, 2009.

Literatura, linguagem, cultura. Rio de Janeiro: J. Diniz, 2000.

DINIZ, J.; TELES, G. M. (Orgs.). Diálogos ibero-americanos. Rio de Janeiro: Galo Branco, 2005.

DOSTOIÉVSKI, F. M. Os irmãos Karamázov. São Paulo: Ed 34, 2009. 
EAGLETON, T. O problema dos desconhecidos: um estudo da ética. Rio de Janeiro: Civilização Brasileira, 2010.

As ilusões do pós-modernismo. Rio de Janeiro: Jorge Zahar, 1998.

Ideologia: uma introdução. São Paulo: Boitempo/UNESP, 1997.

Marx estava certo. Rio de janeiro: Nova fronteira, 2012.

ECO, U. Viagem na irrealidade cotidiana. Rio de Janeiro: Nova Fronteira, 1984.

FIGUEIREDO, V. F. de. Da profecia ao labirinto: imagens da história na ficção latino-americana contemporânea. Rio de Janeiro: Imago/UERJ, 1994.

José de Alencar e o projeto de criação de um imaginário Nacional. In:

Latin American Literatures: Comparative History of Cultural Formations. 1 ed. New York : Oxford University Press, 2002, v.III.

Antropofagia: uma releitura do paradigma da razão moderna. In:

RUFFINELli, J.; ROCHA, J. C. de C. (Orgs.). Antropofagia Hoje. São Paulo: É Realizações, 2011.

FLUSER, V. A dúvida. Rio de Janeiro: Relume Dumará, 1999.

FONSECA, M. A. Por que ler Oswald de Andrade. São Paulo: Globo, 2008.

Oswald de Andrade - biografia. São Paulo: Editora Art, 1990.

FORSTER, R. La muerte del héroe: itinerarios críticos. Buenos Aires: Ariel, 2011.

FOUCAULT, M. Arqueologia das ciências e história dos sistemas de pensamento. Rio de Janeiro: Forense Universitária, 2000. (Col. Ditos e escritos II)

Estética: Literatura e Pintura, Música e Cinema. Rio de Janeiro: Forense Universitária, 2001. (Col. Ditos e escritos)

A Microfísica do Poder. Rio de Janeiro: Graal, 1986.

FREUD, S. Totem e tabu e outros trabalhos V.XIII (1913-1914). 2012. Disponível em: http://www.planonacionaldeleitura.gov.pt/clubedeleituras/upload/e_livros/clle000 164.pdf. Acesso em: 15 ago. 2012.

FREYRE, G. Casa Grande e Senzala: formação da família brasileira sob o regime da economia patriarcal. Rio de Janeiro: J.Olympio, 1977. 
FREYRE, G. Sobrados e mucambos: decadência do patriarcado rural e formação do Urbano. Rio de Janeiro: Record, 1996.

GARDIN, C. O teatro antropofágico de Oswald de Andrade: da ação teatral ao teatro de ação. São Paulo: Annablume, 1995.

GAY, P. Modernismo, o fascínio da heresia: de Baudelaire a Beckett e mais um pouco. São Paulo: Companhia das Letras, 2008.

GIACOIA JR, O. Nietzsche $\mathbf{x}$ Kant: uma disputa permanente a respeito de liberdade, autonomia e dever. São Paulo: Editora casa da palavra, 2012.

Crítica da moral como política em Nietzsche. 2012b, Disponível em: http://www.rubedo.psc.br/artigosb/crimornt.htm. Acesso em: 20 nov. 2012.

GIDE, A. O pensamento vivo de Montaigne. São Paulo: Martins, 1960.

GRAECIA ANTIQVA. A principio ad anno domini 529. Disponível em: http://www.greciantiga.org/. Acesso em: 7 jun. 2011.

HABERMAS, J. O discurso filosófico da modernidade. Martins Fontes: São Paulo, 2002.

HABERMAS, J; RORTY, R. Filosofia, racionalidade e democracia: os debates Rorty \& Habermas. São Paulo: Ed. UNESP, 2005.

HADOT, P. O que é a filosofia antiga? São Paulo: Loyola, 1999.

HALL, S. A identidade cultural na pós-modernidade. Rio de Janeiro: D\&PA, 1992.

HOLANDA, S. B. de. Raízes do Brasil. São Paulo: Companhia das letras, 1995.

HOLANDA, S; PRADO, A. A. O espirito e a letra: estudos de crítica literária. São Paulo: Companhia das Letras, 1996.

HOY, D. C. Foucault: A critical reader. Oxford: Basil Blackwell, 1986.

HYPPOLITE, J. Introdução à filosofia da história de Hegel. Lisboa: Edições $70,1988$.

JAEGER, W. Paideia: a formação do homem grego. São Paulo: Martins Fontes, 2001.

JAMESON, F. A virada cultural: reflexões sobre o pós-moderno. Rio de Janeiro: 2006.

Espaço e imagem. Rio de Janeiro: Ed. UFRJ, 1994.

JAUGUERI, C. A. Canibalismo, calibanismo, antropofagia cultural y consumo en América Latina. Madrid: Iberoamericana, 2008. 
KELSEN, H. A justiça e o direito natural. Coimbra: Almedina, 2001.

KUMAR, K. Utopianism. Buckingham: Open University Press

KUNDERA, M. A arte do romance. São Paulo: Cia das Letras, 2010.

LA BOÉTIE, E. Discurso da servidão voluntária. São Paulo: 1982.

LABRIOLA, R. Neobarroco na América Latina, teoria literária e incômodo epistemológico In: Revista Eutomia. Ano 1, v.2. Pernambuco, 2008. Disponível em:http://www.revistaeutomia.com.br/volumes/Ano1-Volume2/especialdestaques/Neobarroco-na-America-Latina_Rodrigo-Labriola.pdf. Acesso em: 19 ago. 2012.

LARROSA, J. O ensaio e a escrita acadêmica. In: Educação e realidade. 2003. Disponível em: http://seer.ufrgs.br/educacaoerealidade/article/viewFile/25643/14981. Acesso em: 10 nov. 2012.

LATOUR, B. Jamais fomos modernos. Rio de Janeiro: Editora 34, 1994.

LEFEBVRE, H. Marxismo. Porto Alegre: L\&PM, 2011.

LEITE, S. U. Crítica clandestina. Rio de Janeiro: Taurus Editora. 1986.

LEZAMA LIMA, J. A expressão americana. São Paulo : Brasiliense, 1988.

MACHADO, R. Foucault, a filosofia e a literatura. Rio de Janeiro: Jorge Zahar. 2000.

Nietzsche e a verdade. Rio de Janeiro: Rocco, 1984.

MARTINS, H. Canibais europeus e antropófagos brasileiros In: Oswald de Andrade e outros. São Paulo: Conselho estadual de cultura, 1973.

MARX, K. A Miséria da filosofia. São Paulo: Grijalbo, 1976.

Manifesto do partido comunista - 1848. Porto Alegre, L\&PM, 2001.

MARX, K.; ENGELS, F. A ideologia alemã. Rio de janeiro: civilização Brasileira, 2007.

MERQUiOR, J. G. De Praga a Paris: uma crítica do estruturalismo e do pensamento pós-estruturalista. Rio de Janeiro, 1991.

MIGNOLO, W. Lógica das diferenças e política das semelhanças da literatura que parece história ou antropologia, e vice-versa. In: CHIAPPINI, L.; AGUIAR, F. W. de (Orgs.). Literatura e história na América Latina. São Paulo: Edusp, p.115135. 1993.

MONTAIGNE, M. de. Os pensadores. v.1. São Paulo: Nova cultural, 2000. 
MORAES, H. V. de. (Org.). Oswald Plural. Rio de Janeiro: Ed UERJ, 1995.

MORUS, T. A utopia. Porto Alegre: L\&PM, 1997.

NASCIMENTO, E. A antropofagia em questão. In: RUFFINELLI, J.; ROCHA, J. C. de C. (Orgs.). Antropofagia Hoje. São Paulo: É Realizações, 2011.

NIETZSCHE, F. Genealogia da moral: uma polêmica. São Paulo: Cia das letras, 1999.

A gaia ciência. São Paulo: Cia das letras, 2002.

Além do bem e do mal: prelúdio a uma filosofia do futuro. São Paulo: Cia das letras, 1992.

Ecce homo: como alguém se torna o que é. São Paulo: Cia das letras, 1999.

Segunda consideração intempestiva: da utilidade e desvantagem da história para a vida. Rio de Janeiro: Relume Dumará, 2003.

NODARI, A. A única lei do mundo. In: RUFFINELLI, J.; ROCHA, J. C. de C. (Orgs.). Antropofagia Hoje. São Paulo: É Realizações, 2011.

NOGARE, P. D. Humanismo e anti-humanismo em conflito: introdução a antropologia filosófica. São Paulo: Editora Herder, 1973.

NUNES, B. Oswald Canibal. São Paulo: Perspectiva, 1979. Antropofagia ao alcance de todos. In: ANDRADE, O. Do Pau-Brasil à antropofagia e às utopias: manifestos, teses de concursos e ensaios. Rio de Janeiro: Civilização brasileira, 1972.

ORTIZ, F. El contrapunteo cubano del tabaco y el azúcar. Caracas: Fundación Biblioteca Ayacuch, 1978.

ORTIZ, R. A moderna tradição brasileira: cultura brasileira e indústria cultural. São Paulo: Brasiliense, 2001.

PAZ, O. Los hijos del limo. Barcelona: Editorial Seix Barrai, 1981.

PIRES, A. M. G. D. A subjetividade antropofágica e a escrita da vida. In: Verbo de Minas: letras. Juiz de Fora. V.7, N.13, 2008. Disponível em: http://web2.cesjf.br/sites/cesjf/revistas/verbo_de_minas/edicoes/2008_1/14_A_SU BJETIVIDADE_ANTROPOFAGICA.pdf. Acesso em: 11 nov. 2012. 
PIRES, A. M. G. D. (im)Possíveis margens ou: "a virtude é a mãe do vício conforme se sabe". In: Centro, centros - ética, estética. ABRALIC, Curitiba (UFPR), 2011. Disponível em: http://www.abralic.org.br/anais/cong2011/AnaisOnline/resumos/TC0864-1.pdf. Acesso em: 11 nov. 2012.

PONDÉ, L. F. Crítica e Profecia: a filosofia da religião em Dostoiévski. São Paulo: Editora 34, 2003.

RAMA, Á. La ciudad letrada. Montevideo: Arca, 1988.

Las máscaras democráticas del modernismo. Montevideo: Fundación Ángel Rama, Arca Editorial, 1985.

RIBEIRO, D. O povo brasileiro: a formação e o sentido do Brasil. São Paulo: Companhia das Letras, 2008.

ROCHA, J. C. de C.; RUFFINELli, J. (Orgs.). Antropofagia Hoje. São Paulo: É Realizações, 2011.

RODRIGUES, N. Flor de obsessão. São Paulo: Companhia das letras, 1997.

RORTY, R. Filosofia como política cultural. São Paulo: Martins Fontes, 2009. Contingência, ironia e solidariedade. Lisboa: Editora Presença, 1994. . Pragmatismo: a filosofia da criação e da mudança. Belo Horizonte: Editora UFMG, 2000.

ROTTERDAM, E. Elogio da Loucura. Porto Alegre: L\&PM, 2010.

ROUANET, S. P. As razões do iluminismo, São Paulo: Companhia das Letras, 1987.

RUSSEL, B. Ensaios impopulares. São Paulo: Cia Editora Nacional, 1954. História da filosofia ocidental. São Paulo: Cia Editora Nacional, 1957. Elogio ao lazer. São Paulo: Cia Editora Nacional, 1956.

SAFRANSKI, R. O Romantismo uma questão alemã. São Paulo: Estação Liberdade, 2010.

SANT'ANNA, A. R. de. O enigma vazio: impasses da arte e da crítica. Rio de Janeiro: Rocco, 2008.

SANTIAGO, S. Oswald de Andrade ou: elogio da tolerância étnica. In: II CONGRESSO ABRALIC - Literatura e memória cultural. Anais. Belo Horizonte: ABRALIC, 1991. 
SANTIAGO, S. O cosmopolitismo do pobre. Belo Horizonte: Ed.UFMG/ Humanitas, 2004.

. Uma literatura nos trópicos: ensaios sobre dependência cultural. Rio de Janeiro: Rocco, 2000.

SANTOS, R. C. Modos de saber, modos de adoecer - o corpo, a arte, o estilo, a história, a vida o exterior. Belo Horizonte: Editora UFMG, 1999.

SARLO, B. Una Modernidad Periférica: Buenos Aires 1920 y 1930. Buenos aires: Ediciones Nueva Vision, 1996.

SARTRE, J. P. O existencialismo é um humanismo. Lisboa: Presença, 1970.

SCHWARZ, R. Que horas são: ensaios. São Paulo: Companhia das Letras 1987.

SCHWARTZ, J. (Org.). Vanguardas latino-americanas: polêmicas, manifestos e textos críticos (antologia). São Paulo: Edusp: Iluminuras, 1995.

TZVETAN, T. A literatura em perigo. Rio de Janeiro: Editora Bertrand Brasil, 2009.

VOLPI, F. O niilismo. São Paulo: Loyola, 1999.

WAllersteIn, I. The Politics of the World Economy. Cambridge: Cambridge University Press, 1984.

WEBER, M. A ética protestante e o espírito do capitalismo. São Paulo: Companhia das Letras, 2003.

1961.

Historia económica general. México: Fondo de Cultura Económica,

WHITE, H. Meta-historia: a imaginação histórica do século XIX. São Paulo: Editora da Universidade de São Paulo, 1992.

EDUSP, 1994.

Trópicos do discurso: ensaios sobre a crítica da cultura. São Paulo :

ZIZEK, S. The sublime object of ideology. London: Verso, 1997.

A marionete e o anão: o cristianismo entre perversão e subversão Relógio D'agua, 2006.

The plague of fantasies. London: Verso 2008.

Um mapa da ideologia. (org). Rio de Janeiro: contraponto, 1996. 